\title{
النظام القانونــ المنششورات الإدارية
}

$$
\begin{aligned}
& \text { وا محر عبر (الواجر (لجميلى) } \\
& \text { قسم (القانون (العام } \\
& \text { كلية المقورة - جاعة المنصورة }
\end{aligned}
$$




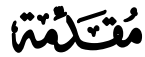

تعد رقابة الإلغاء أقوى وأنجع طرق الرقابـة التي يتسلح بها الأفراد في سبيل إجبار الإدارة على احترام المشروعية، ولهذا فضلا عن تعلق الدعوى المحركة لتلك الرقابـة بالنظام العـام Un recours d'ordre public فإنها توصف بكونها تعد دعوى القانون العـام Droit commun لإلغناء القرارات الإداريـة عمومـاً، بمعنى أنـه يمكن أن توجه إلى أي قرار إداري دون حاجة إلى تصريح من المشرع، بل حتى ولو حاول هذا الأخير تحصينه بـالنص صـراحة على عدم جواز الطعن فيـه بـأي طريـق Insusceptible de recours excès de النصوص تستبعد كل الطعون فيمسا عدا الطعن بالإلغاء أو بتجاوز السلطة pouvoir

(1) C.E. Ass. 17 février 1950, Dme Lemotte, R. p. 110, R.D.P, 1951, p. 478, concl. Delvolvé J, note waline M.; C.E. Ass 17 Avril 1953 Flaco et Vidailiac, R.p. 175, R.D.P 1953, p. 448 concl. Jean Donnedien de Vabres :

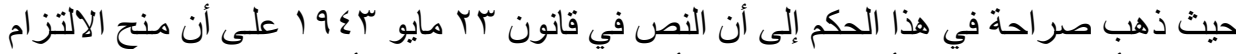

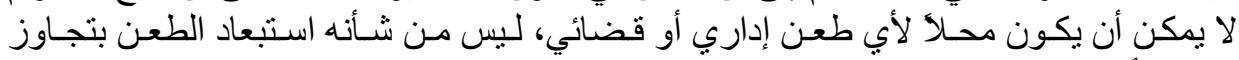

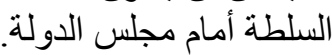

"n'a pas exclu le recours pour excès de pouvoir devant le Conseil d'Etat"

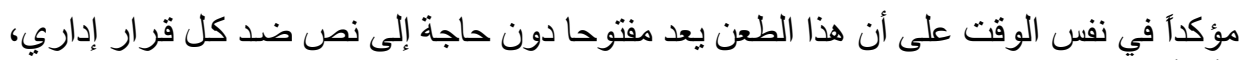
و أن أثره كفالة احتر ام الثرعية طبقاً للمبادئ العامة للقانون. "..le recours pour excès de pouvoir devant le Conseil d'Etat... est ouvert même sans texte contre tout acte administratif,et qui a pour effet d'assurer, conformément aux principes généraux du droit, le respect de la légalité" .= 
غير أن دعوى الإلغاء كما نعرف تدور وجوداً وعدماً مـع القرار الإداري، بحيث إذا انتفى وجود القرار تخلف منـاط قبول الدعوى، أي أن الدعوى تصبح غير مقبولة شكلاً، فالقاضي عليه وقبل فصص مشروعية العمل المطعون فيه بالإلغاء التحقق من أن الطعن قد تم توجيهه ضد عمل إداري صـادر بـالإرادة المنفردة يؤثر بذاته في المراكز Acte faisant القانونية أو من شأنه ترتيب آثار قانونية وهو ما يعبر عنه بالقرنسية grief

ومـن هنـا كانت المشكلة التـي واجهت القاضسي الإداري بالنسبة لقبول الطعن

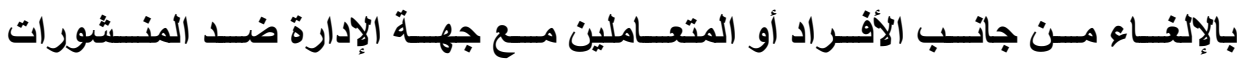
الإدارية Les circulaires administratives

ونقصد بالمنشورات الإداريـة موضوع دراستنا تلك التعليمـات instructions أو الكتب المسصلحية notes de services التـي يوجههـا الرؤســاء الإداريسين وعلى الأخص الـوزراء مـنهم بمقتضي سـلطتهم الرئاسـية إلى مرؤوسـيهم متضضنة تفـسير وتوضـيح القـوانين واللـوائح الـسـارية، وبيــان كيفــة تنفيـذها أي وضـعها

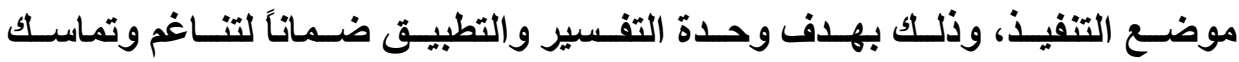

$=$ De Laubadère A, Venezia J.C., Gaudemet Y., Traité de droit administratif, Tome I, LGDJ. 11 ème éd 1990, p. 410 et s.; Chapus R.,Droit du contentieux administratif, Montchrestien, 13 ème éd., 2008, , p. 215, 226, 232 et s.

د. سليمان الطماوى، القضاء الإداري، الكتاب الأول قضاء الإلغاء، دار الفكر العربي، 1917 1913

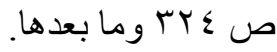
مجلت البحوث القانونيت والإقتصاديت 
(') La cohésion de l'action administrative النشاط الإداري

ورغم أن جهة الإدارة ليست في الأصل ملزمة بإصدار منشورات شارحة لأحكام

القوانين واللوائح، فهي تتمتع في هذا الخصوص بسلطة مطلقة بشأن تقدير مـا إذا كـان

نص معين يحتـاج من جانبها إلى تعليق أو تفسير()، ممـا يعني أن رفض الاستجابة

لطلب إصـارها لا يمكن أن يكـون محـلاً للطعن بالإلغــاء(")، إلا أنـه مـن الملاحظ أنـهـ

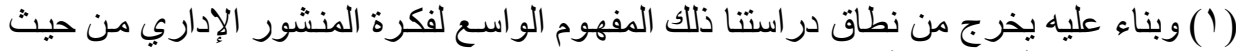

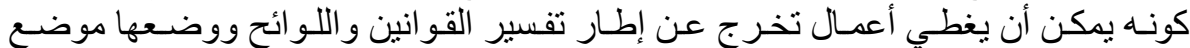

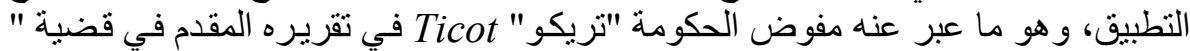

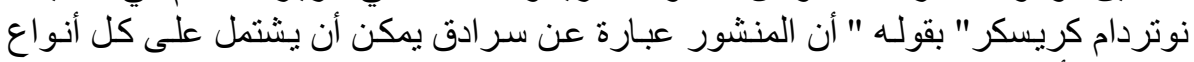

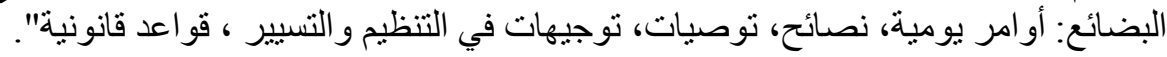

"la circulaire est un pavillon qui peut recouvrir toutes sortes de marchandises : ordres du jour, conseils, recommandations, directives d'organisation et de fonctionnement, règles de droit ".

Tricot B., concl. sur CE.29 janv. 1954, Institution Notre-Dame du Kreisker, RPDA 1954, p.50.

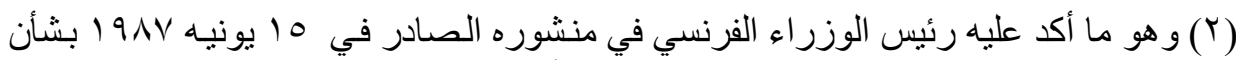

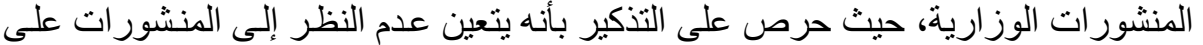

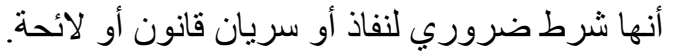

"l'intervention d'une circulaire ne doit jamais être regardée comme une condition nécessaire à l'entrée en vigueur d'une loi ou d'un regalement".

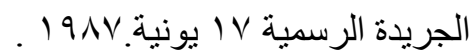

(T)وهو مـا حرص مجلس الدولة الفرنسي التاكيد عليه في أكثر من موضع، راجععلى سبيل

CE, 8 déc. 2000, Syndicat Sud PTT Pays de Savoie, à mentionner aux tables du Recueil Lebon, CE 14 mars 2003 , Louis le Guidec, AJDA 2003, p. 1446,= 
كثير اً مـا يـتم اللجـوء إليهـا، فنظرا في الحقيقـة لكونهـا تتسم بالعموميـة والتجريــ، فضلاً عن بساطة إجر اعاتها حيث لا تخضع في إصدارها لأيـة قيود شكلية وإجرائية على عكس المراسيميم أو القـرارات اللائحيـة، فإنهـا تمثـل بالنسبة للـرئيس الإداري خاصـة الـوزراء مـنهم الوسيلة أو الأداة المثلى التـي تمكنهـه مـن تحقيق وحدة تفسير

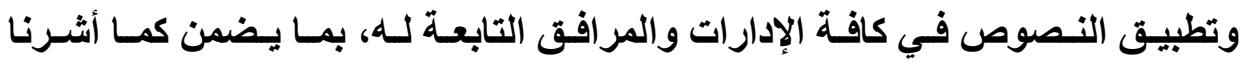
تناغم ووحدة النشاط الإداري داخل وزارته، بعبارة أخرى تعد المنشورات في الحقيقة بالنسبة للـرئيس الإداري الأداة التـي يستطيع مـن خلالهـا معالجـة عدم تمتعـه غالبـاً بالسلطة اللائحيـة تلك السلطة التي تمكن صساحبها من فرض قواعد تتسم بالعمومية

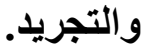

وتبـرز أهميـة دراسـة النظــام القـانوني للمنشـورات الإداريـة، إذا وضــنـا في الاعتبار ذلك الاهتمام الأي يوليه الموظفون لتتلك الطائفة من الأعمال أكثر من اهتمامهر بالنص القانوني الذي يتم توضيحه أو التعليق عليه، ذلك أنها بحكم خضوعهم للسلطة الرئاسية والتزامهم بواجب الطاعة، عليهم بطبيعة الحال الالتزام بمـا جاء فيها على

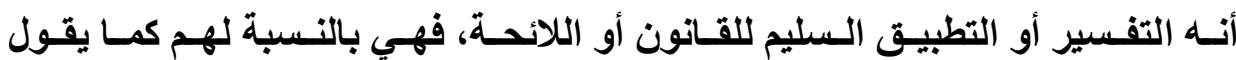

= note Koubi G.:" l'administration n'est jamais tenue de prendre une circulaire pour interpréter l'état du droit existant

راجع أيضا:

Petit J., Les circulaires impératives sont des actes faisant grief, RFDA 2003, p.525; Seiller B., Acte administratif (I-Identification), Rép. cont. adm. Dalloz, janvier 2010, $n^{o}$ 404; Fombeur P., Concl. sur CE, Sect., Duvignères, 18 déc. 2002. RFDA 2003, p. 274 
العميد " ريير" Ripert تكافئ القوانين Valent autant que la loi (')، لارجة يمكن معها القول في الحقيقة بأنه عند صدور قانون جديد فإن الموظف غالبا مـا يعتقد بأنه غير ملزم بتطبيقه، ويتعين رغم نفاذ هذا القانون الامتناع عن تطبيقه لحين صدور منشور شـارح لأحكامه من جاتب الرئيس الإداري الأعلى (†)، وهو مـا حرص الأستاذ " جودميه" Gaudemet على إبرازه بقوله " كم من مرة تؤخر فيها الإدارة التطبيق الفعلي للقانون، نظرا لأنه لم يصدر أو تمتلكك بعد التفسير الداخلي الذي يضمن وحدة

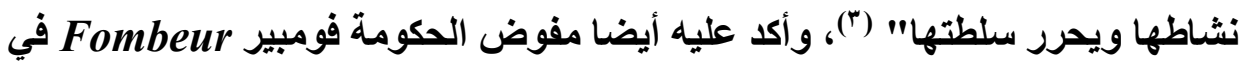
تقريره الثهير المقدم في قضية دوفينيير Duvignères حيث يقول إن الواقع الإداري أو الممارسات الإدارية تظهر أن " المنشورات تحتل أهمية كبيرة، لارجة أن الإدارات ترجع إليها بصورة أكبر من رجوعها للقوانين والمراسيم التي يفترض قيام المنشورات

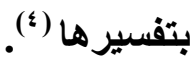

(1) RIPERT G., Les forces créatrices du droit, LGDJ, 1955, p.369.

$$
\text { (r) }
$$

Chapus R.,. Droit administratif, général, T. I, Montchrestien, 9 éd, 1995, P.456.

(3)"Combien de fois l'administration retard-t-elle l'application effective de la loi parce qu'elle ne dispose pas encore de l'interprétation interne qu'assure l'interprétation interne qui assure l'unité de son action et libérera son bras".

Gaudemet Y.,Fonction interprétative et fonction législative : aménagements juridiques de leurs rapports, Interprétation et Droit, éd. Bruylant 1 PUAM, 1995, p. 211.

(4)" dans la pratique administrative, les circulaires revêtent une grande importance, à tel point que les services s'y réfèrent parfois plus qu'aux lois et aux décrets qu'elles entendent interpréter".

Fombeur P., Concl. sur CE, Sect., 18 déc. 2002, Duvignères, RFDA 2003, op.cit, p. 280. 
ومن هنا كانت خطورة هذه الطائفة من الأعمال، ذلك أنها وإن كانت تبدو من

حيث الظاهر مجرد أداة من أدوات الضبط الداخلي للإدارة la police interne de أو تدبير داخلي Mesures d'administration. منها كما أشرنا يتمثل في إعلام الموظقين مسبقاً بالمسلك La conduite الذي يجب عليهم إتباعه تجاه نص قانوني معين، إلا أن أثرها من الناحية الواقعية يتعدى المحيط الداخلي للإدارة، وهو مـا حاول مفوض الحكومـة تريكو Tricot إقـاع مجلس الدولـة

Notre-Dame "الفرنسي به في تقريره الثهير المقدم في قضية نوتردام "كريسكر du Kreisker المنشورات الإدارية في النظام القانوني الفرنسي إلا أن صياغته لهذا الدور كانت تحمل في الحقيقة شكل أو معنى التحذير ،حيث يقول " إن الإدارات المعاصرة تميل إلى تعزيز ورفع مكانة المنشور الإداري في التسلسل الهرمي للأعمـال الإداريـة، فترابط المشاكل التي تضاعف من الوزراء المطلوب توقيعهم على نفس المرسوم أو القرار، وبطء أو ثقل التحركات الإدارية، وعدم الاستقرار الوزاري والذي قد يفرض إعادة دورة توقيعات النص من جديد، كل هذه العوامل تدفع الإدارة إلى أن تلدرج في المنشور قواعد كـان يجب أن تصدر بمرسـوم أو بقرار "، مختتمـا ملاحظته بقولـه " نحن نشهد تراجعاً لقاعدة القـانون أو لسيادة القـانون لصالح عدم الثبات والسرية أو الخصوصية"(')،

(1) " la tendance des administrations contemporaines est à promouvoir la circulaire dans la hiérarchie des actes administratifs. L'interdépendance des problèmes, qui multiplie les ministres contresignataires d'un décret ou d'un arrêté, la lourdeur des transmissions administratives, l'instabilité ministérielle qui oblige souvent à recommencer le circuit d'un texte= 
ولا شك أن مفوض الحكومة بتلك العبارات أراد في الواقع تتبيه مجلس الدولة الفرنسي إلى خطورة تلكك الطائفة من الأعمال الإدارية على حقوق وحريـات المتعاملين مـع جهة الإدارة الأمر الأي يوجب التوسع في قبول الطعن من جاتبهم ضدها بالإلغـاء، ذلك أن الاستمرار في النظر إليها على أنها لا تعدو مجرد تدبير داخلي لا يتجاوز حدود الإدارة

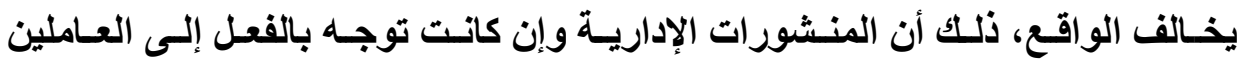
بالمرفق دون غيرهم، فإن ذلك إنمـا يتم في الحقيقة لتطبيق مـا تتضمنه من توجيهات وقواعد وأحكـام في علاقـاتهم مـع المتعـاملين معهم مسن الجمهور، وبالتـالي فبإن مـا . تضمنته يمكن أن ينعكس على هؤلاء بما يؤثر في مراكزهم وأوضـاعهم القانونية، ممـا

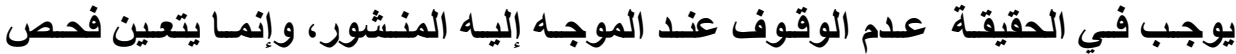
مضمونه ومحتواه والأثر المترتب عليه. وهو مـا استجاب إليسه مجلس الدولـة الفرنسي تـدريجياً، كمـا استجاب أيضا لتلك الاعتبارات مجلس الدولة المصري، وإن كان كما سنرى قد توقف عند مرحلة معينة من مراحل تطور الطعن ضد المنشورات في القضاء الفرنسي، وهي المرحلة السابقة على عام Y . . r، ذلك أنه ابتداءً من العام المشار فقد شهد قبول الطعن ضد المنشورات في

= exigeant plusieurs signatures, tous ces facteurs poussent aujourd'hui l'administration à inclure dans la circulaire des règles qui auraient dû être énoncées par décret ou par arrêté ... On assiste ainsi à un recul de la règle de droit vers le précaire et le confidentiel".

Tricot B., concl. sur CE.29 janv. 1954, Institution Notre-Dame du Kreisker, RPDA 1954,op.cit, p.50. 
ولم يتوقف تغيير النظرة إلى المنشورات الإداريـة في فرنسا عند حد القضاء، ذلك أن الأهمية التي تحتلها تلك الطائفة من الأعمـال في الحياة الإدارية، جذبت أيضاً انتباه كل من المشرع العادي والمشرع التنظيمي، ونقصد بهذا الأخير السلطة اللانحية، حيث حساول كل منهمـا بـداء مـ السبعينات وفي إطـار تحسين وتجديـد العلاقةـة بين الإدارة والجمهـور إيجـاد آليـة أو وســيلة يمكـن مـن خلالهــا إجبـار جهـة الإدارة على التصرف في وضح النهار بجعل جميع منشوراتها معلنة ومعلومـة للجميع إعمالاً للحق في العلم أو الاطلاع، والذي يفرض الكشف عما تحت يد الإدارة من منشورات وتعليمات تتصرف في ضوئها دون أن تكون معلومة للجميع، والتي أطلق عليها مجلس

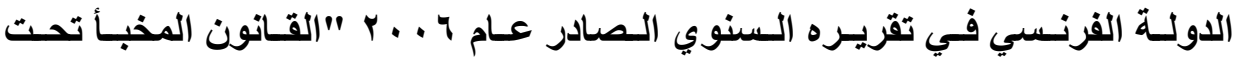
الأرض droit souterrain. (')، للالالة على صعوبة الوصول إليها، بعبارة أخرى حاول كل منهما البحث عن آلية تحقق انفتاح وشفافية الإدارة بجعل ما اعتمدت عليه في لهي

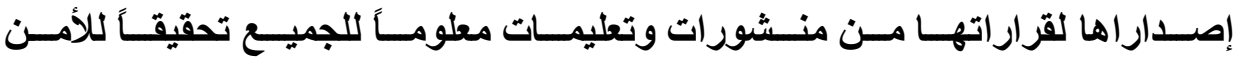

القانوني Sécurité juridique.

والسؤال الآن هل نجح القاضي الإداري بالفعل في التظلب على عقبة التببير الداخلي التي تتصف بها المنشورات الإداريـة والتي كاتت تقف حائلاً بينه وبين قبول الطعن ضدها بالإلغاء، وذلكك تأسيساً على أنها بهذا الوصف من المفترض ألا تحدث بذاتها آثارا قانونية، الأمر الذي ينفي عنها وصف القرار الإداري؟ وإذا كان قد نجح فما هي الارجة التي وصل إليها في هذا الخصوص؟ وهل نجحت الآليات والوسـائل التي لجأ

(1)Rapport de 2006, Sécurité juridique et complexité du droit, La Documentation française, Paris 2006, p. 331.

1. 
إليها المشرع الفرنسي في سبيل إلزام جهة الإدارة بالكشف عن مـا تحت يدها من منشورات تتصرف في ضوئها دون أن تكون معلومة للجميع بغض النظر عن طبيعتها القانونية أي بعيداً عمـا إذا كاتت تشكل أو لا تشكل قراراً إدارياً ممـا يجوز الطعن فيهـ

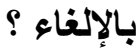

وقبل الانتقال إلى الإجابة عن تلكك التساؤلات فإنتا نود التنويهه إلى أنـه نظراً إلى أن النظام القانوني للمنثورات الإدارية في القانون المصري لم يثهد بعد ما طرأ على هذا

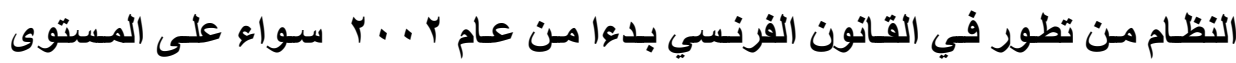
القضائي أم المستوى التثريعي، فإنتا سنعتمد في تقسيمنا لخطة الدراسة على الترتيب الزمني لهذا التطور في القانون الفرنسي. وبناء عليه سنقسم دراستتا للنظام القانوني للمنشورات الإدارية إلى فصلين: الفصل الأول: النظام القانوني للمنشورات الإدارية قبل عام ץ +. r. الفصل الثاني: النظام القانوني للمنشورات الإدارية بدءا من عام ؟ ...r. 


\section{الفصل الأول \\ النظام القانوني للمنشورات الإدارية

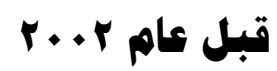

قدمنا أن المنشورات الإدارية تم النظر إليها في البداية على أنها لا تعدو مجرد

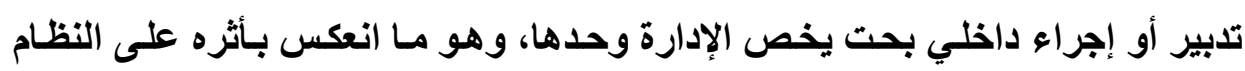

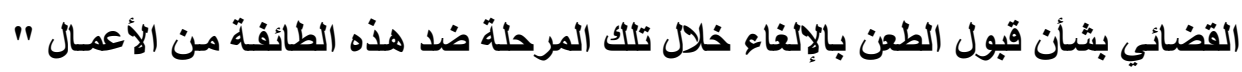

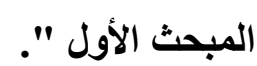

ورغم الأهميـة التي تحتلهـا المنشورات الإداريـة في الحيـاة الإداريـة وحيـاة

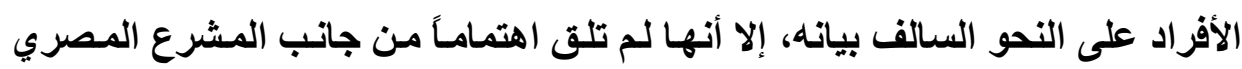

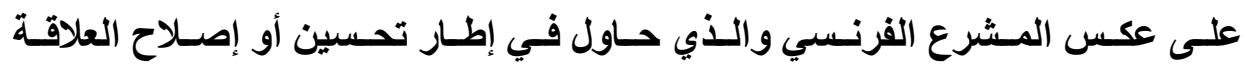

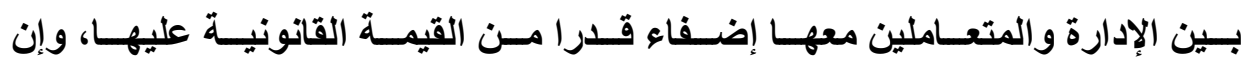
كانت محاولته باءت بالفشل نتيجة تمسك مجلس الدولية الفرنسي بموقفه " المبحث

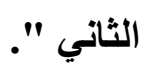




\section{المبحث الأول \\ هرقف القضاء بشأن قبول الطمن بالإلغاء \\ في المنشورات الإدارية}

قدمنا أن المنشورات الإداريـة تم النظر إليها في البدايـة على أنها لا تعدو أن

تكون مجرد إجراء داخلي لا شأن للمتعاملين مـع جهة الإدارة بـه، وذلك انطلاقا من أن الفرض فيها أنها لا تضيف جديداً ولا تتضمن بالتسالي تأثير ا في مراكزهم وأوضساعهم

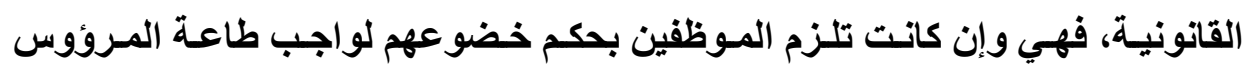
لرئيسه، فإنها تعد بالنسبة للأفراد كما لو كانت غير موجودة، بعبارة أخرى لا تتمتع في

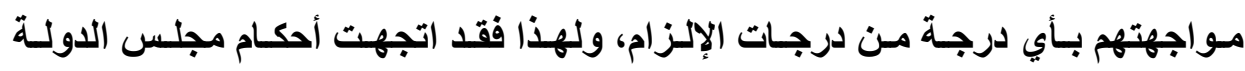
الفرنسي في مرحلة أولى وفقاً لرأي العديد من الفقهاء إلى الاعتمـاد بشأن قبول الطعن بالإلغاء في المنشورات على صفة الطاعن بأن يكون من المخـاطبين بالمنشور ، مقررا

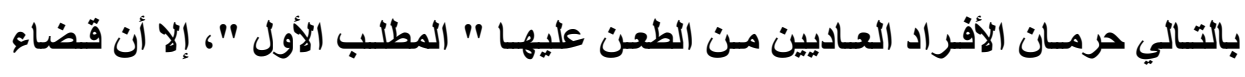

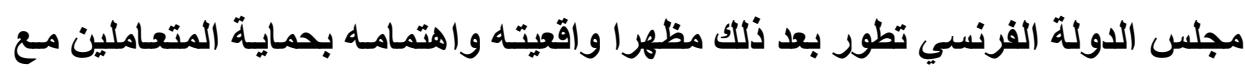
جهة الإدارة وذلكك انطلاقـا من أن المنشورات الإداريـة وإن كانت في الحقيقة موجهـة بالفعل إلى الموظفين فبان ذلك إنمـا يتم لتطبيق مـا تتضمنه من تفسيرات وتوجيهات وتعليقات في علاقاتهم مع المتعاملين مع الإدارة، وبالتالي فإن آثارهـا يمكن أن تنعكس على هؤلاء، مما يعني أنه يتعين عدم الوقوف عند صفة متلقي المنشور لتحديد من لـه حق الطعن، وإنما يجب فحص مضمونه ومحتواه لتحديد ما إذا كـان الرئيس الإداري قد وقف عند حد تفسير وتوضيح القوانين واللوائح القائمة وبيان كيفية تنفيذها ، أم أنه قد أضاف جديداً بما قد يؤثر سلباً على حقوق وحريات الأفراد، أو بعبارة أخرى بمـا يؤثر

مجلة البحوث القانونيت والإقتصاديت 
فـي المراكـز والأوضــاع القانونيـة للأفراد، ويسسمح بالتــالي لهـؤلاء بـالطعن عليـهـ بتجاوز السلطة شـأنه في ذلك شـأن أي قرار إداري صـادر عن الإدارة، وبحيث يصبح وجود المصلحة أو تخلفها هو المعيار الذي يعتمد عليهه في هذه الحالة بشأن قبول الطعن بالإلغاء، بغض النظر عما إذا كـان هذا الأخير مقام من جانب الموظفين أو من جانب الأفراد، وترتيباً على مـا تقدم قام بشأن قبول الطعن بـالتمبيز بين نـوعين من المنشورات: المنشورات التفسيرية Les circulaires interprétatives و التي أطلق عليها الأستاذ شابي Chapus المنشورات الحقيقية Les vraies circulaires (') والمنششورات اللائحيـة Les circulaires réglementaires، مجـرداً الأولـى

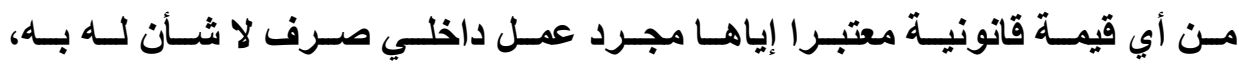
أمسا الثانيـة فاعتبرهـا مصدراً مـن مصادر المشروعية مثلهـا في ذلكت مثل أيـة لاتحـة تصدر عن الإدارة، مما يعني خضوعها لما تخضع له هذه الأخيرة من أحكام" المطلب

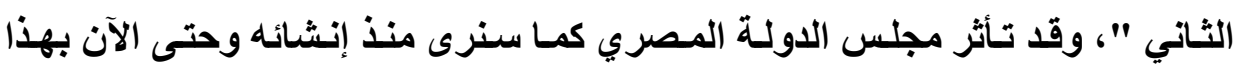
التمييز.

(1) Chapus R., Droit administratif général, T. 1, op.cit, p.456.

مجلت البحوث القانونيت والإقتصاديت 


\section{المطاب الأول}

الاعتماد في قبول الطعن بالإلغاء على صفة الطاعن

ففي البداية اعتماداً على فكرة أن المنشور إنما يوجه في الأسـاس أو في المقـام

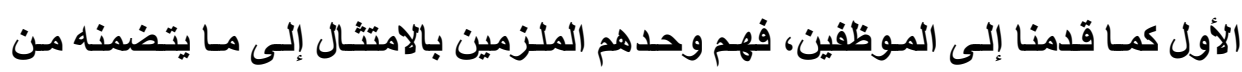
توجيهات، وذلك انطلاقًا من واجب الطاعة المفروض عليهم حيال رؤسائهم، فقد اتجهت الأحكام الأولى لمجلس الدولة الفرنسي وفقاً لتحليل العديد من الفقهاء إلى قصر حق إنى الطعن بتجـاوز السلطة في المنشور غير المشروع، وكذا الاحتجـاج بمـاورد فيـه من الأن أحكام عند الطعن في القرارات المتعارضـة معـه، على الموجها إليهم المنشور أي على الموظفين، أما بالنسبة للأفر اد فنظراً لعدم اندراجهم في الحيـاة الداخلية لـلإدارة، فيان المنشور بالنسبة لهم لا يعدو أن يكون مجرد عمل داخلي لا شأن لهم بـه، بعبارة أخرى

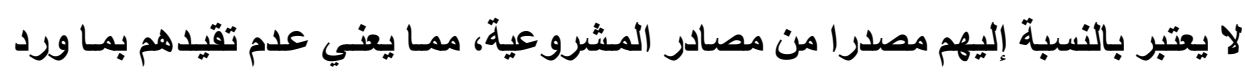

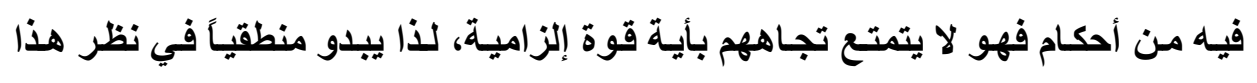

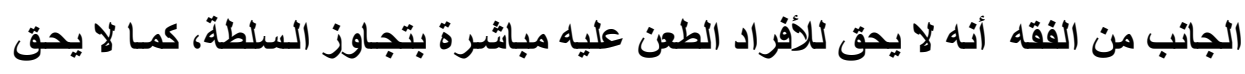
لهم الاحتجاج بعدم مشروعية ما اتخذ قبلهم من قرارات أو إجراعات تتعارض مع ما هو بهو وارد فيه.

وهو مـا استتنجه العميد هوريوHauriou عند تحليله للأحكام الأولى لمجلس

الدولة الفرنسي المتعلقة بتلك الطائفة من الأعمـال، وذلك بمناسبة تعليقهه على حكم Cochet d'Hatecourt للغير لا تعد مصدرا من مصادر المشروعية، ذلك أنهم لا يعملون داخل الإدارة، أمسا

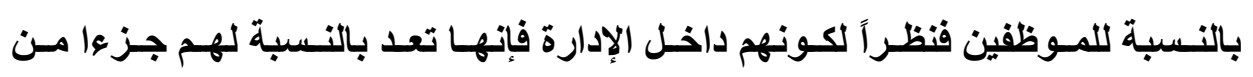

مجلت البحوث القانونيت والإقتصاديت 
المشروعية، فهي لا تتتج إذن آثراً قانونياً ولا تتمتع بقيمة القواعد القانونية إلا داخل

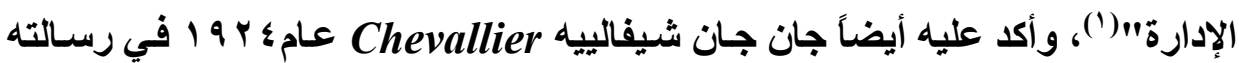
حول الأمر المصلدي والطعن بتجـاوز السلطة، حيث انتهى بعد فحص متأن لأحكام

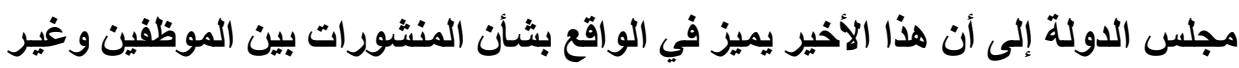
الموظفين Fonctionnaires et non Fonctionnaires (") محاولاً تقديم تبرير لموقف المجلس بقوله أن ما دفع المجلس لذلك إنما يرجع في الواقع إلى أنه انطلق من

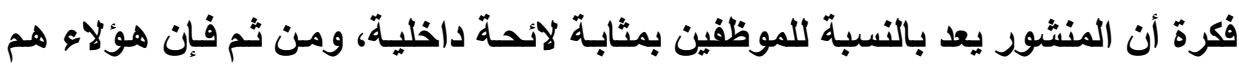

(1)"les instructions ministérielles au regard des tiers,. . . ne font pas partie de la légalité, parce que les tiers ne sont pas à l'intérieur de l'administration; au regard des fonctionnaires du service, au contraire, elles font partie de la légalité, parce que ceux-ci sont à l'intérieur de l'administration. Elles ne produisent donc d'effet de droit et n'ont valeur de règles de droit qu'à l'intérieur de l'administration ".

Hauriou M., Note sous CE, 22 février 1918, Cochet d'Hattecourt, S. 1921, 2ème cahier, Illème partie, p. 9.

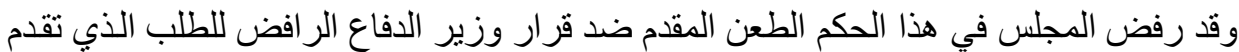

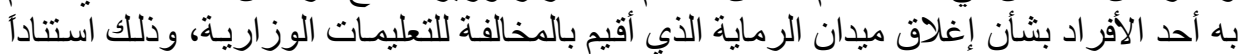

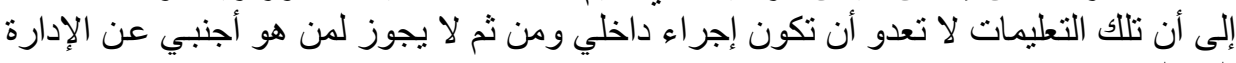

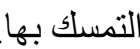

(2) L'auteur écrit ainsi :" Au point d. vue de l'annulation. le Conseil déclare les fonctionnaires recevables à lui déférer directement la circulaire qui les lèse illégalement dans leur situation de carrière. Au point de vue de la violation, il les admet à invoquer devant lui, à l'appui d'un recours contre une décision de l'administration. l'inobservation d'une circulaire qui leur confère au contraire des garanties ou des droits"

Chevallier J.-J., L'instruction de service et le recours pour excès de pouvoir, Thèse Nancy 1924, p. 328. 
وحدهم المخـاطبين بأحكامـه (')، وهـي ذات الحجـة التـي انطلق منهـا "هوريـو" عنـــ

تفسيره لموقف المجلس()، كذلك أيضاً حرص الأستاذ دي لوبـاديير De Laubadère عند استعراضه للمراحل التي مر بها قضاء مجلس الدولة بشأن الطعن في المنشورات والاحتجاج بما تضمنته من أحكام على الإشارة إلى أن المجلس في أحكامـه الأولى كـان يميز في هذا الخصوص بين الموظفين وغير الموظقين(").

(1)" Le Conseil s'est inspiré plus ou moins consciemment de cette idée que la circulaire constituait à l'égard des fonctionnaires une sorte de règlement intérieur...Le Conseil d'Etat a compris que les fonctionnaires...vis-à-vis d'elle une catégorie spéciale d'administrés au sein de l'institution".

Chevallier J.-J., L'instruction de service et le recours pour excès de pouvoir, op.cit, p. 328.

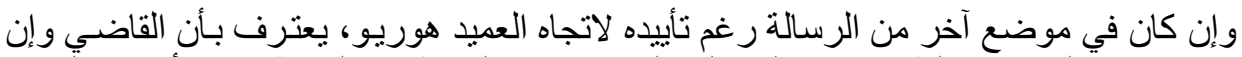

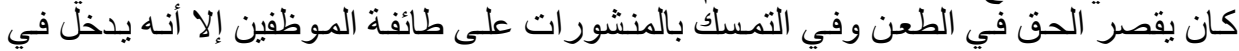

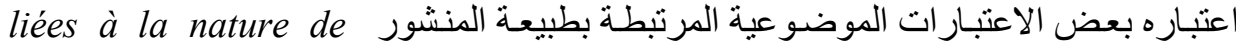
أl'acte

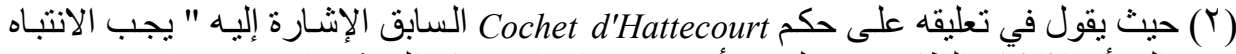

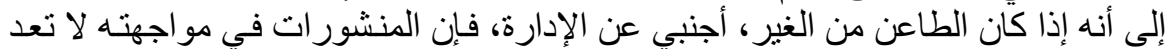

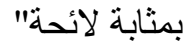

"faisons attention que le requérant est un tiers, un propriétaire étranger à l'administration, les circulaires vis-à-vis de lui ne valent pas règlement."

(3) De Laubadère A., Vénézia J.C., Gaudemet Y., Traité de droit administratif, T. I, op.cit, P. 585.

ومن الأحكام التـي يشار إليها للتـليل على حصر المجلس الطعن المباثـر في المنشور غير المشروع على طائفة الموظفين دون الأفر اد النئ راجع:

CE. 24 nov. 1916, Fabre, Rec. p. 479; CE. 27 déco 1918, Legrand, p.1161; CE. 21 févr. 1919, Record, p. 171 ; CE. 17 févr. 1922, Association professionnelle de la Préfecture de police, RDP 1922, p. 245, note Jèze; : CE. Il juin 1920, Hiti, Rec p. 573;CE. 29 oct. 1920, Deloze, Rec. p. 900; CE. 24 mars 1922, Chambre syndicale des fabricants d'eaux gazeuses de Paris, RDP, 1922, p. 247 , note Jèze. $=$ 
غير أن فهم الأحكام الأولى لمجلس الدولـة على النحو السالف بيانهـ لـم يلق

ترحيباً من جانب بعض الفقهاء، وعلى رأسهم الأستاذ "ريفيرو" Rivero، حيث أنكر

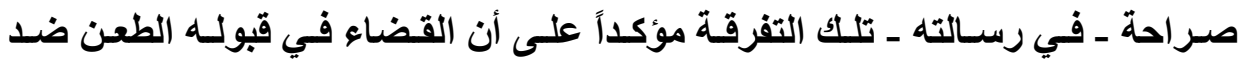

المنشورات لم يعتمد بصورة قاطعة على صفة الطاعن La qualité du requérant،

وإنما على مضمون العمل أو الإجراء contenu de l'acte

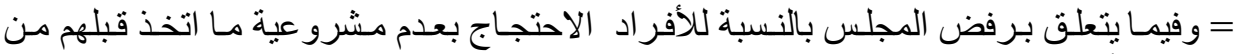

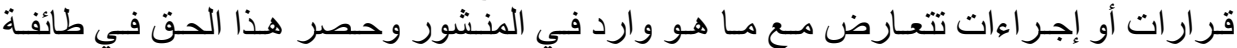

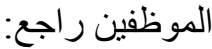

CE. 2 aout 1907, Morand-Montiel, S, 1910,III, p.41; CE. 22 févr. 1909, Rageot, S, 1912, III, p. 41; CE. 22 févr. 1918, Cochet d'Hattecourt, S. 1921, p. 9 , préc.

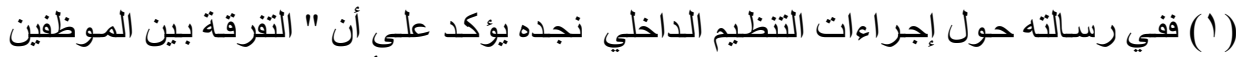

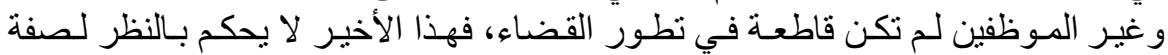
الثخص و إنما بالنظر للموضوع في ضو فـ مضمون الإجر اء.

" La distinction entre fonctionnaires et non fonctionnaires $n$ 'a aucunement été décisive dans l'évolution de la jurisprudence qui se décide non pas ratione personae mais ratione materiae au vu du contenu de l'acte".

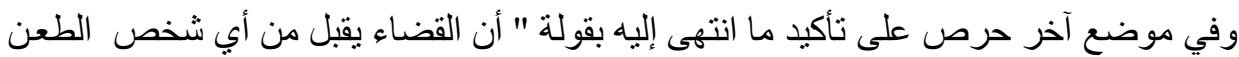

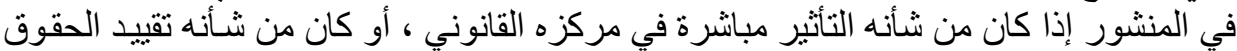
التي يستمدها من القانون أو النائحة"

La jurisprudence " admet les requérants, quels qu' 'ils soient, à attaquer la circulaire lorsqu'elle a une incidence directe sur le statut légal et lorsqu' 'elle restreint les droits qu'ils tiennent de la loi ou du règlement".

RIVERO J., Les mesures d'ordre intérieur administrative, Essai sur les caractères juridiques de la vie intérieure des services publics, Sirey 1934, $p$. 101 et 109.

$$
\text { راجع أيضأ ص } 0 \text {. . . }
$$




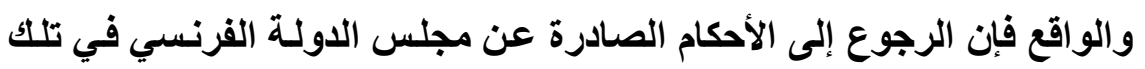

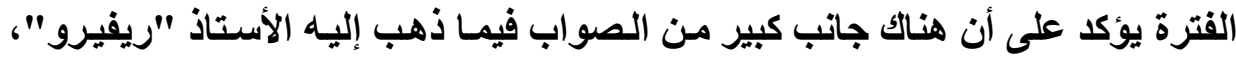

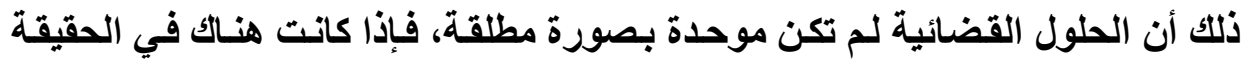
أحكام قد يستخلص منها ما انتهى إليه العميد "هوريو" والأستاذ "شيفالييه"، إلا أن هناك أحكامًا أخرى صدرث خلال نفس الفترة تثكك في تلكك النتيجة وتؤكد على اعتماد

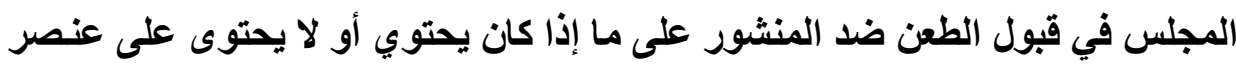

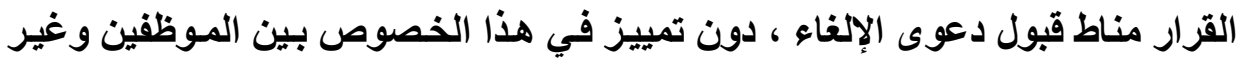
الموظفين، ذلك أنه سمح في بعض الأحكام لغير الموظفين بالطعن المباثر في المنشور

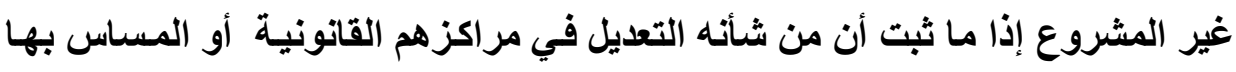

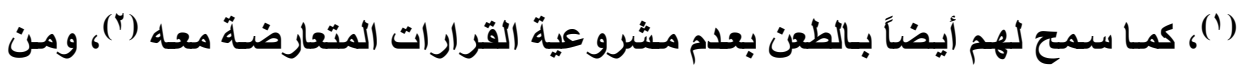

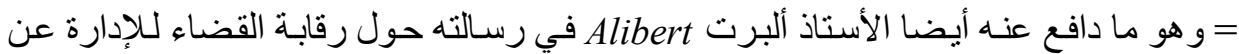

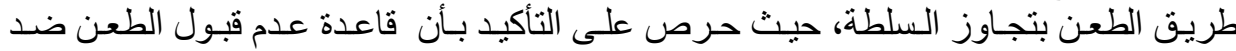

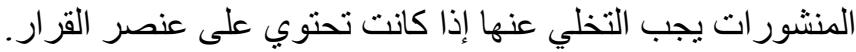
" la règle de l'irrecevabilité du recours contre l'instruction. doit céder les fois que la circulaire ou l'instruction contient un élément de décision

directe. Certaines circulaire ont tous les caractères qui distinguent les discisions., immédiatement exécutoires: elle font grief à toute une catégorie d 'administrés; ceux-ci sont donc recevables à en demande l'annulation" .

Aubert R., Le contrôle juridictionnel de l'Administration au moyen du recours pour excès de pouvoir, Payot, 1926, p. 118 .

CE. 18 juin 1926, Sieur Belkacem Bentami et autres, S. 1927, III. p. 614; CE. 10 janv. 1936, Giraud, Rec. p. 46.

CE. 1 déc. 1933, Quinard et autres, D.H. 1934, p. 40.

$$
\text { r. مجلت البحوث القانونيتوالإقتصاديت }
$$


زاوية أخرى نجد بأنه لم يكن يقبل تلقائيا الطعن المقدم من جانب الموظقين حيث كـان يرفض الطعن إذا ما ثبث أمامه عدم احتواء المنشور على عنصر القرار (')، كما أنهله لم يكن يسمح لهم في جميع الأحوال بالاحتجاج بما ورد في المنشور من أحكام عند الطعن

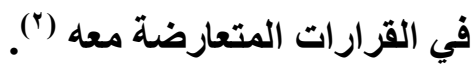

وبعيداً عن أحكام المجلس المشار إليها، والتي قد تلقي بظلال من الثك حول مـا استخلصه العميا "هوريو" والأستاذ "شيفالييه"، وتبعهم في ذلك العديد من الفقهاء، من أن مجلس الدولة كان يقصر في البداية حق الطعن في المنشورات والاحتجـاج بمـا ورد فيها من أحكام على الموظفين دون الأفراد، استناداً إلى كونهم وحدهم المخاطبين

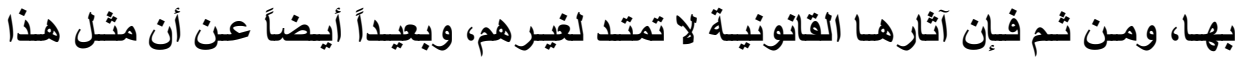
الاسـتنتاج كـان يمثل تطوراً ملحوظـاً إذا مـا تمت مقارنتـه بالاتجـاه الفقهي الذي كـان يتزعمه العميا Duguit "دوجي" في ذلك الوقت، والذي كـان ينكر كل قيمة قانونيـة للمنشورات حيث كان يعتبرها مجرد أعمال مادية لا تنتج أية آثار قانونية وذلك تأسيسا على أن مصدر ها لم يكن في نيته أن يسن لائحة لعدم تمتعه بالسلطة اللائحية بالنسبة

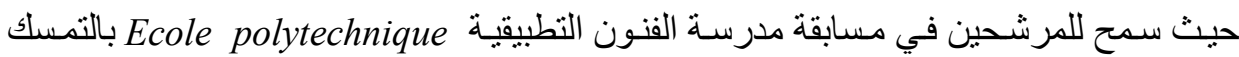
بمنشور طعنأ في قرار وزاري متعارض معان.

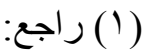

CE. 26 mai 1922, Dlle Noël, Rec. p. 92 ; CE. 26 déc. 1924, Carbon-Ferrière, Rec. p. 1077; CE. 20 mai 1924, Bacquié, Rec. p. 518; CE. 27 mai 1931, Portail, p. 402.

CE. 28 déco 1917, Steiner, Rec. p. 866;CE. 21 nov. 1919, Roux, Rec. p. 833 ; CE. 21 janv. 1921, Jérémie, Rec. p, 67; CE, 9 juill. 1926, Vaulot, Rec. p. 727; CE. 1929, Lemonnier, Rec. p.100; CE. I5 févr., 1929, Veyretout. Rec. p. 201 ; CE. 28 nov. 1930,Sieur Junco et Dame Guerre, Rec. p. 1106

مجلة البحوث القانونيت والإقتصاديت 
لموضوع المنشور (')، فإن التبرير الذي كان يقف وراء تلكك التقرقة لا يتفق مـع الواقع، ذلك أن المنشورات وإن كاتت توجه في الحقيقة إلى الموظفين فإن ذلك إنما يتم لتطبيق ما تتضمنه من تعليمات وتوجيهات وتفسيرات في علاقاتهم مـع المتعاملين مـع الإدارة،

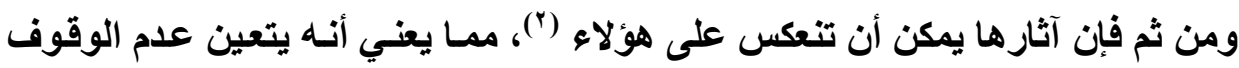

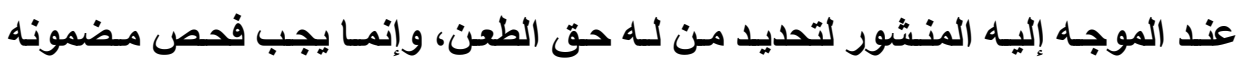
ومحتواه Le contenu et la portée de l'acte الإداري قد وقف عند حد تفسير وتوضيح القوانين واللوائح القائمة وبيان كيفية تنفيذها

(1)"Les instructions et les ordres par voie générale des fonctionnaires supérieurs ne sont des actes ayant le caractère juridique; ce sont de simples opérations matérielles qui, par elles-mêmes, ne produisent aucun effet de droit" .

Duguit, Traité de droit constitutionnel, tome II, Albert Fontemoing, 1928, p. 360.

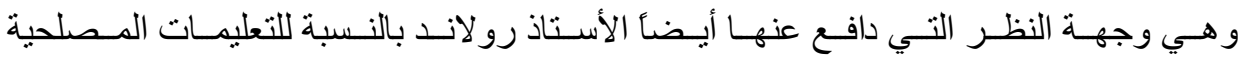
Instructions de service Simples operations materielles. مادية

Rolland, Precis de droit administratif, 10eme ed, 1951, n¹31.

BEnoit F.P., Le droit administratif français, Dalloz, 1968,p.490.

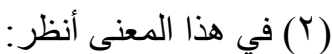

Petit J., Les circulaires impératives sont des actes faisant grief, Note sous Conseil d'Etat, Section, op.cit p. 510.

(T) و هو ما عبر عنـه الأستاذ Douence في رسالته بقولـه" بأن هنـاك إجماع على ألى أن المعيار يجب ألا يستمد من الثكل ولكن من مضمون ومحتوى العمل

"Il est unanimement admis que le critère doit être tiré non de leur forme mais du contenu et de la portée de l'acte".

Douence J.C., Recherches sur le pouvoir réglementaire de l'administration, Thèse, LGDJ,1969, p. 314. 
أي وضعها موضع التنفيذ تحقيقا لوحدة التفسير والتطبيق، أم أنه قد أضاف جديدا إليها بما قائثر في المراكز والأوضـاع القانونية للمتعاملين مـع جهة الإدارة (')، ويسمح بالتـالي لهؤلاء بـالطعن عليه بتجاوز السلطة شـأنه في ذلكك شـأن أي قرار صـادر عن الإدارة، وبحيث يصبح وجود المصلحة أو تخلفها هو المعيار الذي يعتمد عليه في هذه الحالة بشأن قبول الطعن من عدمه بتجاوز السلطة، بغض النظر عما إذا كان هذا الأخير مقام من جانب الموظقين أو من جاتب الأفراد.

وهو ما استقر عليه مجلس الدولة الفرنسي مع بداية النصف الثاني من القرن

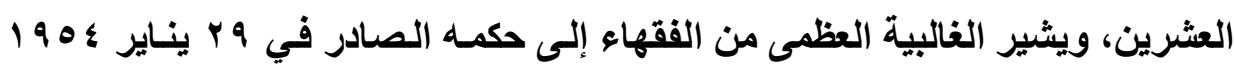
في قضية"معهد سيدة كريسكير" Institution Notre-Dame du kreiskaer

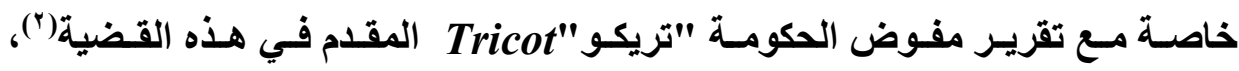
باعتباره الحكم الرئيسي أو المؤسس لبدايـة مرحلة جديدة استقر فيها مجلس الدولنة الفرنسي بشأن قبول الطعن ضد المنشورات لما يقرب من نصف قرن على التمييز في Les circulaires اخـل المنسشورات بـين نــوعين: المنسشورات التفـسيرية

، Les circulaires réglementaires والمنشورات اللائحية interprétatives وهو ما سنعالجه في المطلب التالي.

(1)Vedel G. Droit administratif, T. I, éd 1990, PUF, P. 258.

(2) CE, Ass., 29 janv. 1954, Institution Notre-Dame du kreiskaer, Rec. p. 64 ; RPDA 1954, p. 50, concl. Tricot B. ; AJDA 1954, II bis, p. 5, chron. F. Gazier et M. Long.

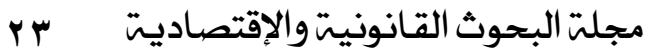




\section{الاطلب الثاني \\ التمييز بشأن قبول الطعن بالإلغاء \\ بين المنشورات التفسيرية والمنشورات اللائمية}

"هعيار الإضافة"

سنعرض أولا لمضمون هذا المعيار " الفرع الأول"، والصعوبات التي واجهت

تطبيقه " الفرع الثاني"، ثم نتـاول دعوى فحص المشروعية كوسيلة تسمح بفحص مشروعية المنشورات التفبيرية من جانب القاضي الإداري " الفرع الثالث ".

\section{الفرع الأول}

\section{هضمون هعيار الإضافة}

سنعرض " أولاً " لمضمون المعيار في القضاء الفرنسي ثم نعقبه ببيـان موقف

القضاء المصري من هذه التفرقة " ثانياً ".

أولاً : مضمون معيار الإضافة في القضاء الفرنسي

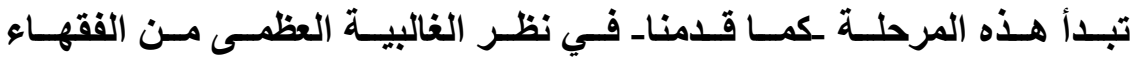

الفرنسيين (')، بصدور حكم مجلس الدولة الفرنسي في قضية "معهد سيدة كريسكير"

(1) من هؤلاء على سبيل المثال:

De Laubadère A., Vénézia J.C., Gaudemet Y. , Traité de droit administratif, op.cit, p.586; Chapus R., Droit administratif général, T. 1, op.cit, p.548;. Vedel G. Delvolvé P., Droit administratif, T. 1, PUF, éd1990, p. 259. ; Debbasch Y. et Ricci. J.C., Contentieux administratif; Dalloz, 7 éd., 1999, $n^{\circ}$ 810; Dupuis G., Guédon M.-J., Chrétien P., Droit administratif, Colin, 5éd. 1996, P. 529.

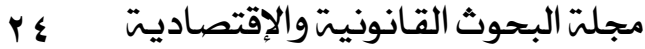


Institution Notre-Dame du kreiskaer المجلس بوضوح فيما يتعلق بقبول الطعن بتجـاوز السلطة بين المنشور التفسيري

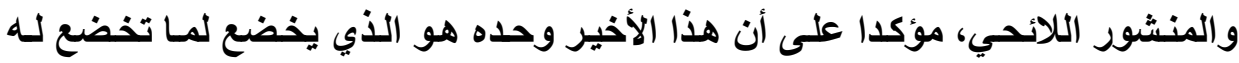

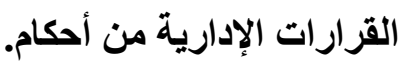

وتتلخص وقائع هذه القضية في أن وزير التعليم الوطني قام في 11 يناير عام

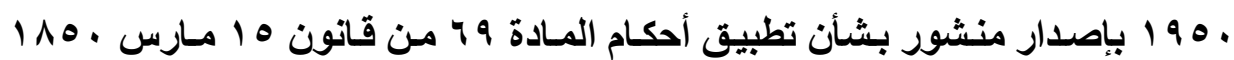

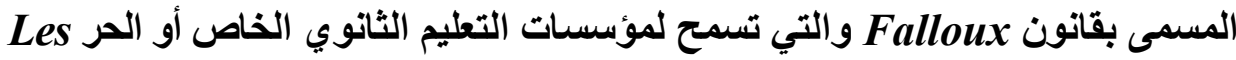
établissements libres d'enseignement secondaire على مساعدات أو إعانسات Subventions من البلايات والمديريات والدولة على ألا

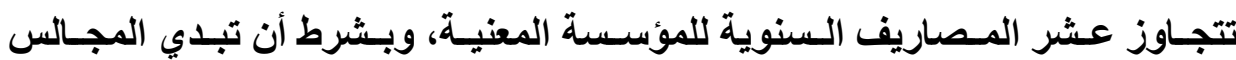

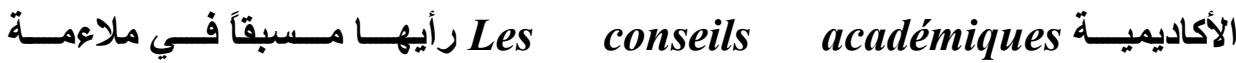

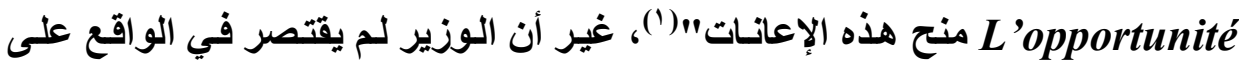

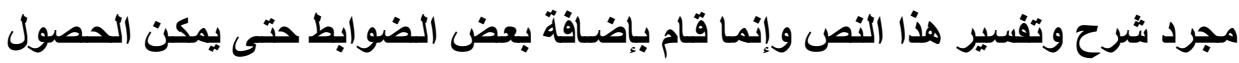
على تلكت الإعانة، حيث أوجب من جهة وقبل البت في طلب الإعانة من جانب المجالس Conseils و العامسة Conseils généraux

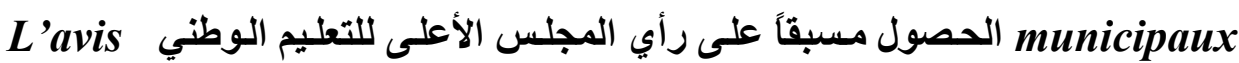


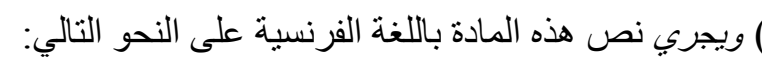

" les établissements libres d'enseignement secondaire pourront obtenir des communes, des départements et de l'Etat des subventions sans que celles-ci puissent excéder le dixième des dépenses annuelles des établissements en cause et à condition que les conseils académiques aient été appelés à donner leur avis préalable sur l'opportunité de ces subventions".

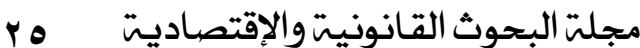


أخرى طلب من مديري المجالس الأكاديمية استيفاء بعض البياتـات أو المستندات قبل

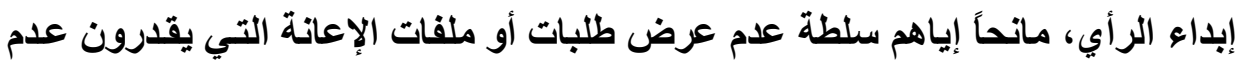

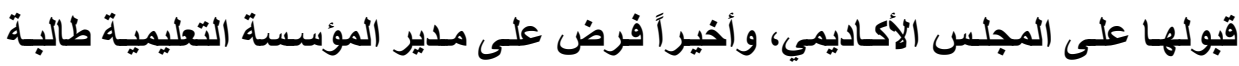

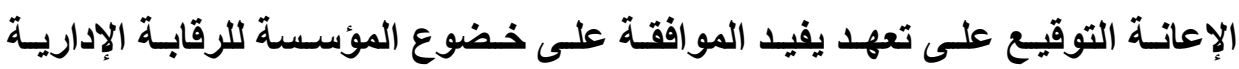
والتربوية Contrôle administratif et pédagogique وذلك في حالة ما إذا تمت فلت

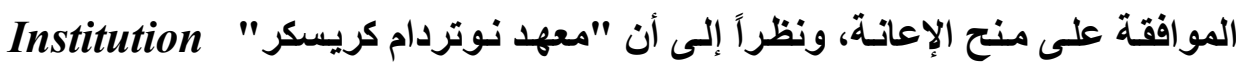
Sotre-Dame du Kreisker استيفاء كافة المسندات التي تطلبها منشور وزير التعليم، لذا فقد قام نائب محافظ إقليم

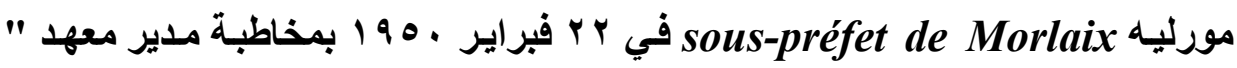

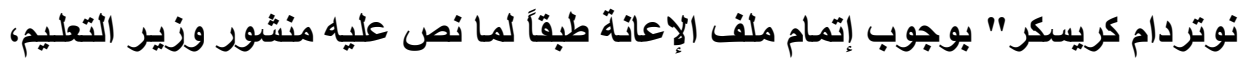

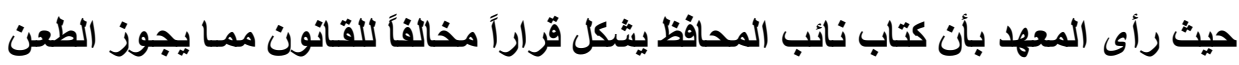

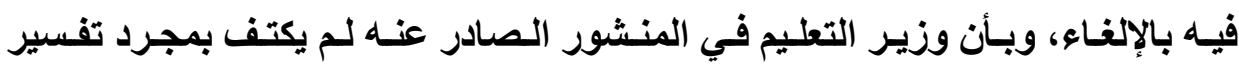

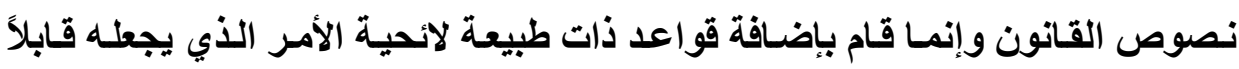

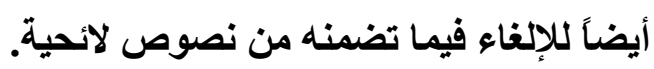

غير أن مجلس الدولة لم يشارك المعهد الرأي بالنسبة لكتاب نائب المحافظ، حيث رأى بأنه لا يعدو أن يكون مجرد تذكير بالتنظيم القائم ودعوة لإتمـام ملف الإعانة

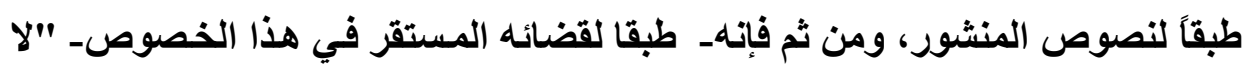

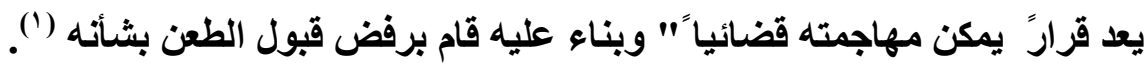

ومسن التطبيقـات القضائية لمثنل هذه الصورة مـن صـور القرارات والتـي يطلاق عليهـا بالفرنسية: Actes déclaratifs ou recognitifs:

CE. 11 avr. 1951, Fédération nationale des fabricants français de vêtements masculins, Rec. p.184; CE Sec. 10 avril 1970, Cangardel, Rec.p.242: =

$$
\text { مجلة البحوث القانونيت والإقتصاديت }
$$


"Cette lettre ne comporte pas de décision susceptible d'être déférée au Conseil d'Etat statuant au contentieux".

أما بالنسبة لمنشور وزير التعليم فقد قبل الطعن عليه وذلك تأسيساً على أن "

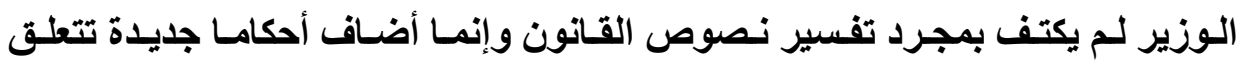
بتكوين ملفات الإعانة، الأمر الذي يضفي عليه بالنسبة لهذه الأحكام الطابع اللانحي، ومن ثم فإن من حق معهل " نوتردام كريسكر" الطعن عليه بتجاوز السلطة" (1)،

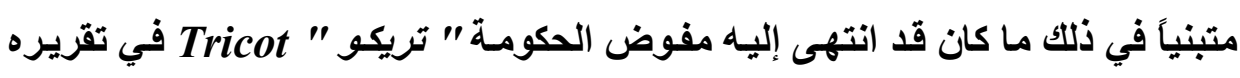

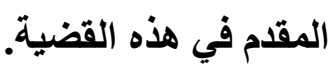

وكما هو واضح فقل اعتمد المجلس بثأن قبول الطعن على مـا إذا كان المنشور قد أضاف جديداً من عدمه أي على مضمون المنشور، ولهذا يطلق على المعيار الذي

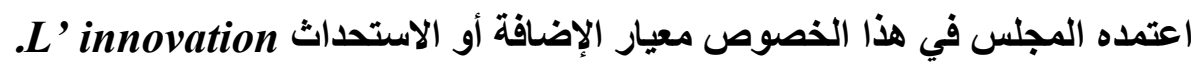
وقد انتهى المجلس في تلك القضية إلى تأييد طلبات معهد " نوتردام كريسكر"

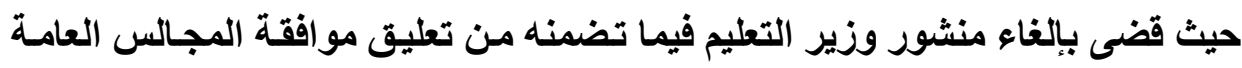

$$
\text { = بثأن التذكير بالسلطة التقديرية التي تمنحها بعض النصوص لجهة الإدارة. }
$$
CE. Sec. 10 juillet 1995, Synd. des embouteilleurs de France, Rec. p.301, RFDA 1996, p.1221: Règlement communautaire

(1) "le ministre de l'Education nationale ne s'est pas borné à interpréter les textes en vigueur, mais a, dans les dispositions attaquées, fixé des règles nouvelles relatives à la constitution des dossiers de ces demandes de subventions ; que, par suite, ladite circulaire a, dans ces dispositions, un caractère réglementaire ; que, dès lors, l'institution Notre-Dame du Kreisker est recevable à déférer au Conseil d'Etat les prescriptions contestées de cette circulaire."

rv مجلتّ البحوث القانونيت والإقتصاديت 
و المحلية على الحصول مسبقاً على رأي المجلس الأعلى للتعليم الوطني، وأيضا فيما

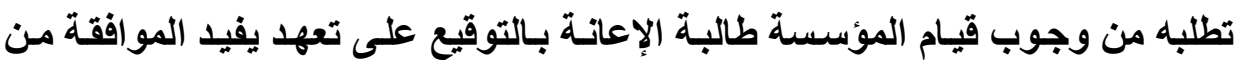

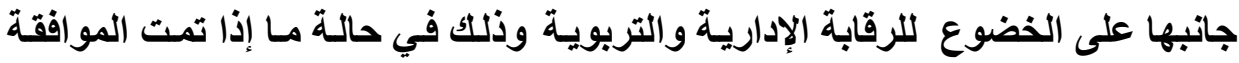

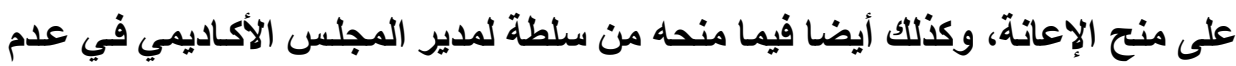
العرض على هذا المجلس طلبات أو ملفات الإعانة التي يقدر عدم قبولها (') والواقع فإن هذا الحكم لا يعد أول حكم يأخذ فيه مجلس الدولة الفرنسي بهذا المعيار ذلك أنه في الحقيقة طبق هذا التوجه خلال النصف الأول من القرن العشرين في العديد من الأحكام، حيث سمح كمـا سبق وأثرنا ـ دون تمييز بين الموظفين والمتعاملين

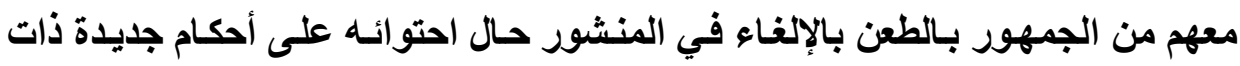
مضمون آمر لا سند لها في القانون الذي يتم تفسيره أو بيان كيفية تطبقه، تؤثر تأثيراً

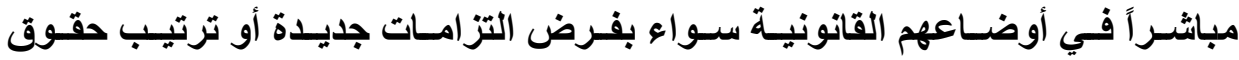

$$
\text { ويجري منطوق الحكم باللغة الفرنسية على النحو النالي: }
$$

"DECIDE : Article 1er : La circulaire en date du 11 janvier 1950 est annulée en tant qu'elle soumet les dossiers des demandes de subvention formées par des établissements libres d'enseignement secondaire auprès de départements ou de communes à l'avis préalable du Conseil supérieur de l'Education nationale, en tant qu'elle a pour effet d'exiger, à peine d'irrecevabilité de la demande de subvention, les pièces qu'elle prévoit et qu'elle confère au recteur le pouvoir de ne pas soumettre au conseil académique les dossiers jugés par lui irrecevables pour ce motif, ainsi qu'en tant qu'elle prescrit la production, par l'établissement qui demande une subvention, d'un engagement de son directeur d'accepter, au cas où ladite subvention serait accordée par un département ou par une commune, le contrôle administratif et pédagogique dudit établissement. Article 2: Le surplus des conclusions est rejeté. Article 3 : Expédition de la présente décision sera transmise au ministre de l'Education nationale." 
جديدة"'، كما سمح أيضاً ـ باعتبار أن المنشور في هذه الحالة سيصبح مصدرا من مصادر المشروعية، مثله في ذلك مثل أية لائحة تصدرها جهة الإدارة - بـالطعن بعدم مشروعية القرارات المتعارضة معه بمعنى آخر الاحتجاج بعدم مشروعية ما اتخذ قبلهم من قرارات أو إجراعات تتعارض مع ما هو وارد فيه من أحكام(؟).

- CE. 5 janv. 1934, Fédel, Rec. P.30.

$$
\text { ( ) (1) فبالإضافة للأحكام السابق الإشارة إليها راجع: }
$$

ويتعلق بمنشور صادر عن وزير التعليم بشأن تحديد شروط القبول في المدارس، حيث الفئ اعتبر

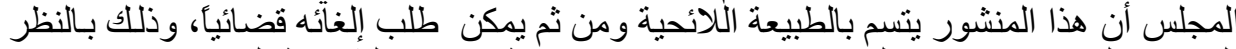

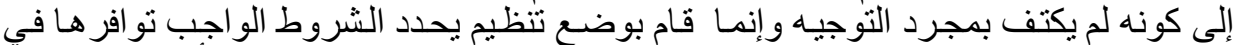

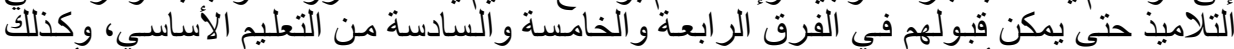

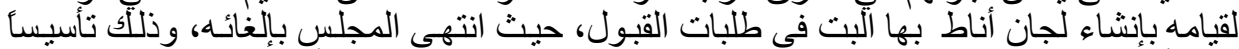

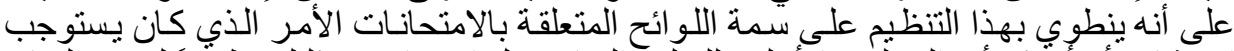

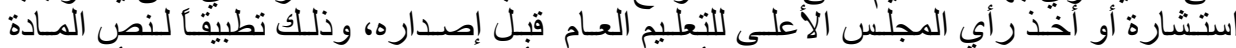

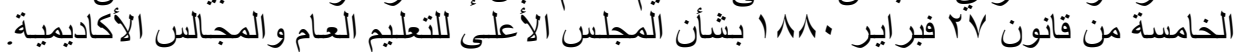

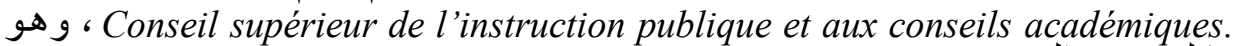

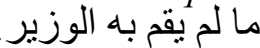

- CE, 6 octobre 1944, Sieur Topin et Chambre syndicale de la meunerie de l'Oise, Rec. P.257.

ويتعلق بتحديد طريقة حساب الضريبة المقررة بموجب المادة العاثرة من قانون 10 أغسطس

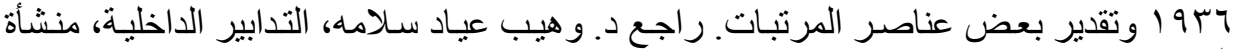

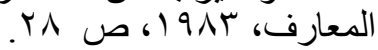

- CE. ler avril 1949, Chaveneau, Rec. P.161, S.1949.3.49, note Delpech.

ويتعلق بمنشور صادر عن وزير التعليم بشأن إلغاء مرفق الارشاد الديني في المدارس الثانويـة،

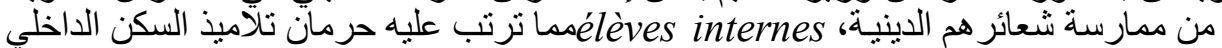

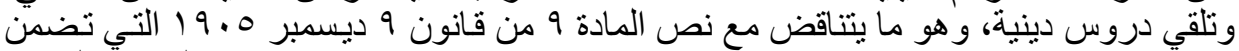
وحرية ممارسة الشعائر الدينية

- CE. 6 nov. 1953, Dame Boisson, Rec .p.478.

ويتعلق بمنشور يضيف شرطالم يتطلبه القانون للحصول على إعانة البطالة.

(2) CE 16 juin 1950. Mugnier, Rec .p.372.

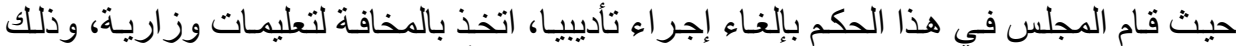

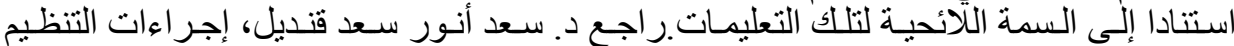

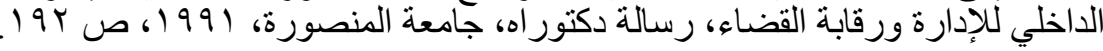


وعلى الوجه المقابل قام أيضاً في العديد من الأحكام بإخضاع المنشورات التي تقتصر على مجرد تفسير وتوضيح القوانين واللوائح القائمة، وبيـان كيفية تنفيذها أي وضعها موضع التنفيذ دون إضافة أية أحكام جديدة، لنظام قضائي ينبع من تجرديها من وصف القرار الإداري، مما يعني وجوب النظر إليها على أنها لا تعد مصدرا من مصادر المشروعية، بعبارة أخرى لا تعدو أن تكون مجرد تدبير داخلي لا شأن للأفراد بـه، ذلك أن الفرض فيها في تقديره أنها لا تضيف جديدا ولا تتضمن بالتالي تأثيراً في مراكز

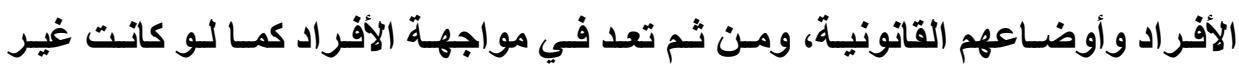
موجودة، فضلكً عن عدم تمتعها في مواجهتهم بـأي درجة من درجـات الإلزام، وترتيبـا على ذلك رفض - وقبل صدور حكم "نوتردام كريسكر " ـ قبول الطعن بتجـاوز السلطة ضد تلك الصورة من صور المنشورات(')، ونظرا بطبيعة الحال لكونها لا تعد مصدراً منشئا للمشروعية، فقد أجـاز لجهة الإدارة الخروج عليها، بمعنى أنه يمكن مخالفتها فيما تصدره من قرارات دون أن يحتج ببطلان القرار لتعارضهه مـع المنشور التفسيري

(1) CE 5 janv.1945,La famille capitalization,D.1945,p.204.

$$
\text { حيث رفض المجلس قبول الطعن تأسيسا على أنه لا يعد ذات طابع لائحي. }
$$

" Elles ne constituent pas des actes d'ordre réglementaires

- CE 9 mars 1951, Guislain, Rec. 142.

ويتعلق بمنشور صادر عن وزير الأشغال بشأن الخطوات الواجب إتباعها لتسوية ودفع بعض التش

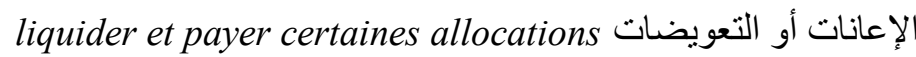

CE 11 avril 1951, Fédération nationale de fabricants de vêtements masculins, Rec. p. 184.

$$
\text { ويتعلق بالمنشور ات التي تكتفي بمجرد التذكير بقرار سابق أو بوجود لائحة. }
$$

les circulaires qui se bornent à rappeler une décision antérieurement prise, ou l'existence d'une réglementation

$$
\text { مجلت البحوث القانونيت والإقتصاديت }
$$


الصادر عنها(')، ومن جهة أخري رفض الاستناد إليها من جاتب جهة الإدارة لفرض قيود والتزامـات غير منصوص عليها في القـانون الذي تقوم بشرحه وتوضيحه(؟) ، فضلاً عن ذلك فنظراً أيضاً لكونها لا تعد كمـا أشرنا ـ مصدراً من مصادر المشروعية فقد رفض أيضاً الاستناد إليها لتقرير مشروعية أو عدم مشروعية القرار المطعون فيه. أمامه، ذلك أنها تعد بالنسبة له كما هو الثأن تمامـا بالنسبة للأفر اد كمـا لو كانت غير موجودة ، بعبارة أخرى فإن فحص مشروعية القرار المطعون فيه أمامه إنما يتم بالنظر فقط إلى الأحكام الواردة مباشرة في القانون أو اللائحة دون التفات إلى مـاورد ورد النص عليه في المنشور التفسيري، وهو مـا حرص على إبرازه في حكمه الصادر في الأول

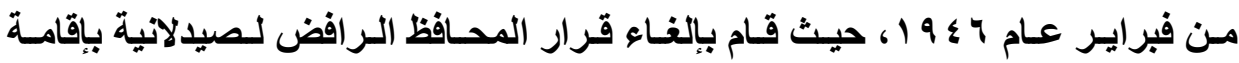
صيدلية في الجهة التي يمارس فيها زوجها الطب، والذي كان قد استتد فيه المحافظ إلى المنشور الوزاري الصادر في V أغسطس ب ؟ 9 ا، والذي يحظر على الأزواج ممارسـة

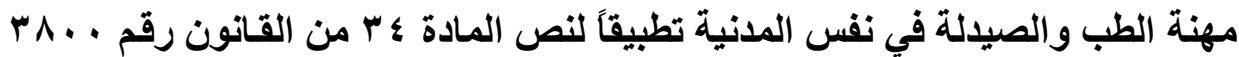

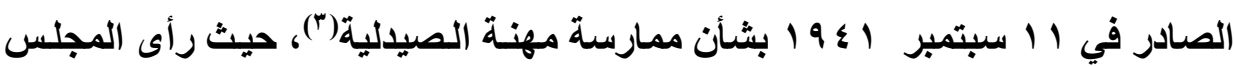
أن نص تلك المادة لم يحظر سوى الاتفاقات التي يمكن أن تتم بين الصيدلي والطبيب médecin praticien, à une " أو جراح الأسنان أو ممرضـة التوليد" القابلـة chirurgien dentiste ou à une sage-femme ، والتي بمقتضاها يتت حصول

(1) CE 27 mars 1939, Colleye, Rec. p. 220

ويتعلق بمنشور صادر عن وزير الحربية بشأن الاجاز ات التي يسنطيع العسكريون المطالبة بها

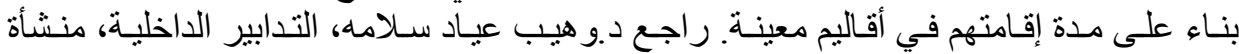

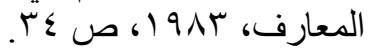

(2)De Laubadère, Traité de droit administrative, Op.cit.,p.587.

(3) relative à l'exercice de la pharmacie

مجلتً البحوث القانونيت والإقتصاديت اس 
هؤلاء على أية فائدة أو نسبة من مبيعات الأدوية التي يصفونها لمرضـاهم (') ومن ثم فإن ممارسة الطب والصيدلة من جاتب الزوجين في نفس المدينة لا يدخل في إطار

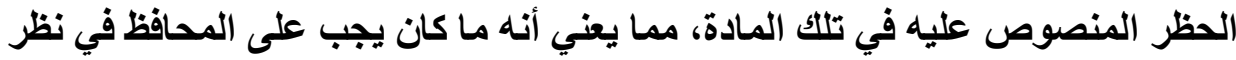
المجلس الاستتاد في رفضه إلى المنشور الوزاري سالف الذكر والذي لا يعدو أن يكون مجرد منشور تفسيري، فضلاً عن أن التحقيق الذي أجراه المفتش الإقليمي للصيدليات

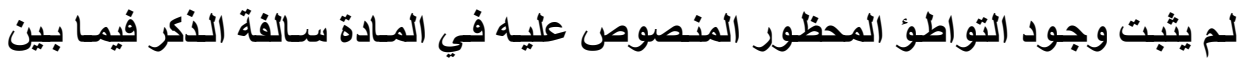

\section{الزوجين "كريستيل" Christelle}

وربمـا يرجع السبب في اهتمام الفقهـ بحكم "نوتردام كريسكر"، واعتباره بايـة الاستقرار الفعلي للمجلس نحو وجوب فحص مضمون المنشور لتحديد مـا إذا كاتت

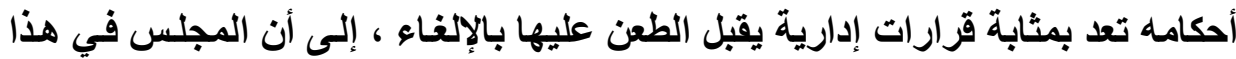
الحكم كسان أكثر صـراحة ووضسوحاً بشأن تعليق قبـول الطعن بتجـاوز السنطة في المنشورات على ثبوت تضمنها لقو اعد جديدة règles nouvelles بالمقارنة بالقانون

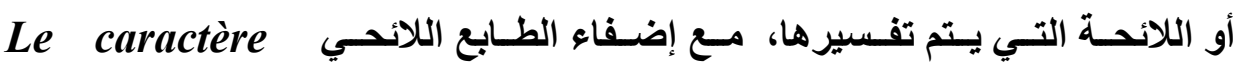
وليها في حالـة ثبوت ذلك، ومن ثم قبول الطعن في هذه الحالـة réglementaire ضدها بالإلغاء، فضلاً عن السماح للأفراد بالتمكك بها في مواجهة الإدارة، كما أن لهذه الأخيرة الاحتجاج بها عليهم ، حيث برر صراحة قبول الطعن بالإلغاء في منشور وزير التعليم بأن هذا الأخير " لم يكتف بمجرد تفسير نصوص القانون وإنما أضساف أحكامـا

$$
\text { (1) ويجري نص هذه المادة باللغة الفرنسية على النحو النالي: }
$$

"Est interdite toute convention d'après laquelle un pharmacien assure à un médecin praticien, à une chirurgien dentiste ou à une sage-femme un bénéfice d'une nature quelconque sur la vente des produits pharmaceutiques, médicament qui ceux-ci peuvent prescrire".

(2) CE 1 fév.1946,Dame ChristelleRec.p.33.

مجلة البحوث القانونيت والإقتصاديت ب r م 
جديدة تتعلق بتكوين ملفـات الإعانـة، الأمـر الذي يضفي عليه بالنسبة لهذه الأحكام الطابع اللائحي، ومن ثم فإن من حق معهد " نـوتردام كريسكر" الطعن عليه بتجـاوز

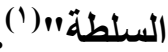

ثانياً: موقف القضاء الإداري المصري

ساير القضاء الإداري المصري اتجاهات مجلس الدولـة الفرنسي بشأن وجوب النظر إلى مضمون المنشور، بحيث إذا توافرت لـه مقومـات القرار اللائحي اعتبره مصدرا للشرعية وكان قابلاً بالتـالي للطعن فيه بالإلفاء شـأنه في ذلكك شـأن أي قرار لانحي، يستوى في ذلك أن يقدم الطعن من جاتب المخاطبين به أو من جاتب الأفراد، أما إذا اقتصر على مجرد تفسير القوانين واللوائح وبيان كيفية تنفيذها دون إضافة فلا يقبل الطعن فيه(†)، وفي هذا تقول المحكمة الإدارية العليا في حكمها الصادر في ـ ب يونيه 99 9 9 " إن القضاء الإداري مستقر على أن هناك من القرارات مـا يقتصر أثره على الإدارة ذاتها ولا تقصد الإدارة من ورائه ترتيب آثار معينة في مواجهة الأفراد ويندرج في هذه الطائفة من القرارات المنشورات والأوامر المصلحية وهى عبـارة عن الأوامر

(1)" le ministre de l'Education nationale ne s'est pas borné à interpréter les textes en vigueur, mais a...fixé des règles nouvelles relatives à la constitution des dossiers de ces demandes de subventions ; que, par suite, ladite circulaire $a$, dans ces dispositions, un caractère réglementaire ; que, dès lors, l'institution Notre-Dame du Kreisker est recevable à déférer au Conseil d'Etat les prescriptions contestées de cette circulaire."

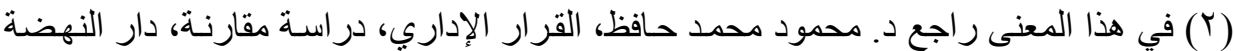

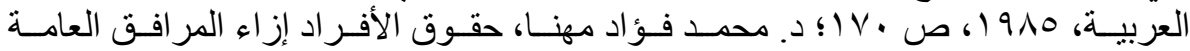

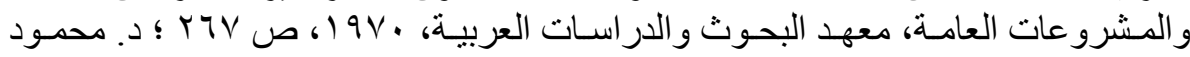

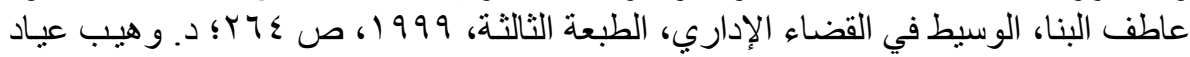

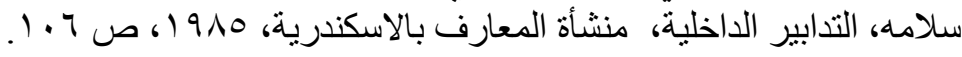


و التعليمات التي تصدر من الرؤساء إلى مرؤوسيهم متضمنة تفسير القوانين واللوائح

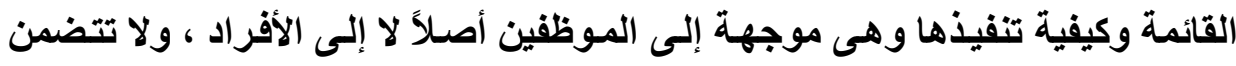

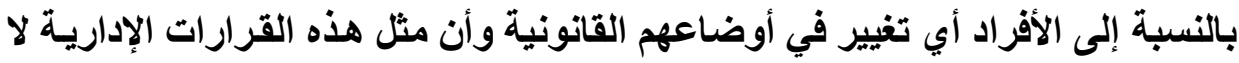
تعد من القرارات الإدارية بالمعنى الإداري ولا يجوز قبول الدعوى بطلب إلغائها لانتفاء

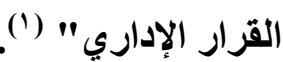

أما إذا تجاوز المنشور حدود التفسير وخلق قاعدة جديدة فإنه ينقلب إلى قرار

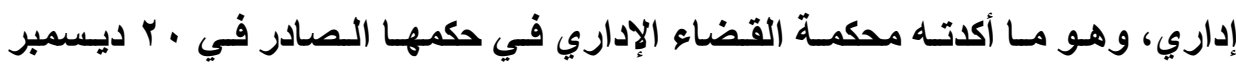
؛ 19 ا وإن كان لا يتعلق بالمنشورات الإدارية وإنما بالقرارات التفسيرية التي تصدرها السلطة التنفيذية بناء على نص في قانون يبيح لها إصدارها، حيث تقول " .إن القرار

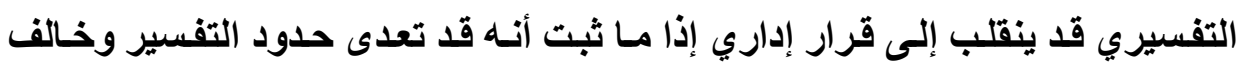

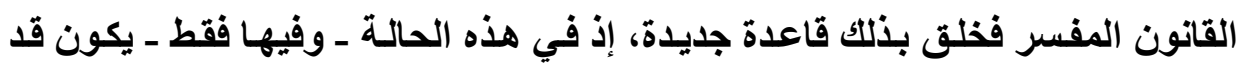

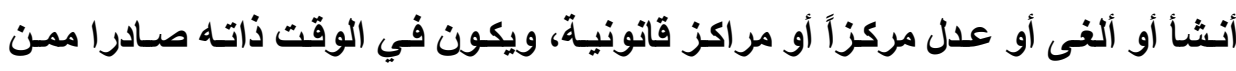

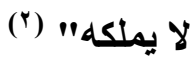

ومـن التطبيقــات القضائية لمــا اعتبـره مجلـس الدولـة المـصري مـن قبيـل

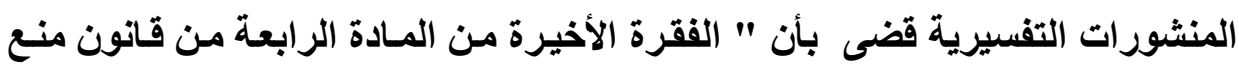

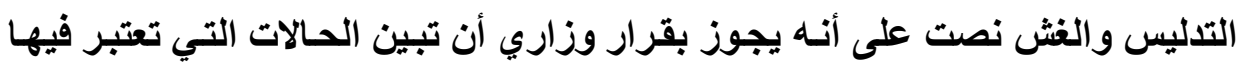

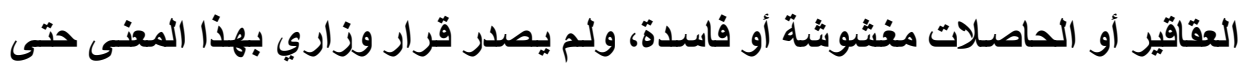

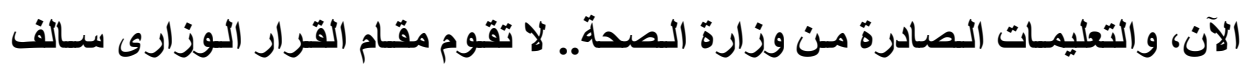

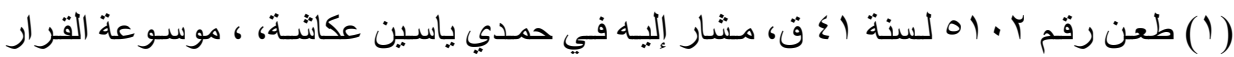

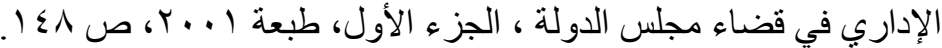

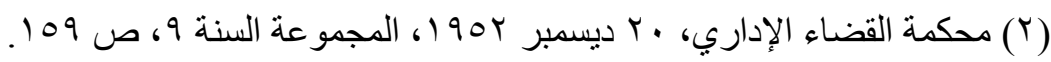

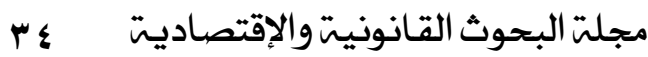


الأكر، ولا تسرى لذلك على الأفراد، فلا يتعدى أثرهـا والحالة هذه الموظفين المطلوب Instructions ou circulaires منهم تنفيذها بوصفها تعليمسات داخلية صرفه administratives بها "(1)، كما قضى بأن" التعليمات الصادرة من وزارة الشئون الاجتماعية في صدد تفسير نصوص القانون رقم VI لسنة به 9 ا بشأن عقد العمل الفردي هى مجرد رأي

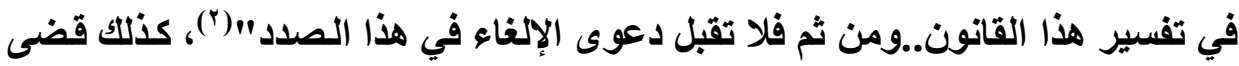
بأن "توجيهات رئيس الوزراء بما تضعه من شروط للترقية بالإضافة إلى تلك المقررة بنصوص صريحة لا تعدو مجرد توجيهات إدارية لا ترقى إلى مرتبة القانون ولا تشكل قيدا على حق الإدارة في إجراء الترقيات ما دامت مطابقة للقانون"(")، كما رفض أيضاً إضفاء وصف القرار اللائحي على الكتاب الصادر من إدارة كاتم أسرار الحربية إلى الحى رئيس إدارة الجيش وذلك استتـاداً إلى أن موضوعه يتــاول" شـأناً عامـاً ووضعا قائمـاً

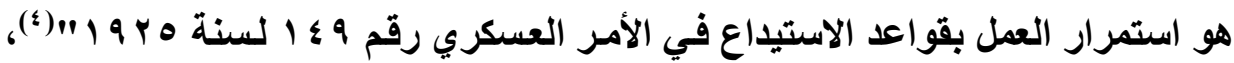
وكذلك أيضا على خطاب المدير العام لمصلحة الضرائب الذي ذكر قيه " أن الرأي قد استقر على إخضاع الصيادلة للضريبة على الأربـاح التجاريـة والصناعية لا يتضمن قرارا إداريا بالمعنى المتعارف عليه فقهاً وقضاء وذللك بحسب منطوق عبارته وظروف الهف إصداره فضلاً عن أنه غير نهائي ممـا يجوز معـه لمصدره العدول عن الرأي المذكور

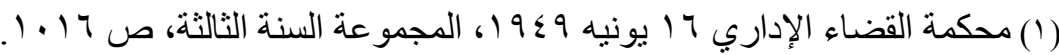

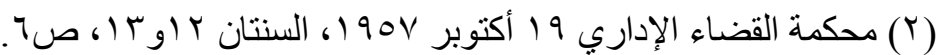

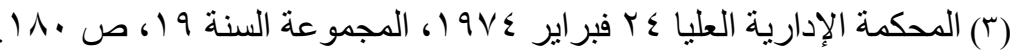

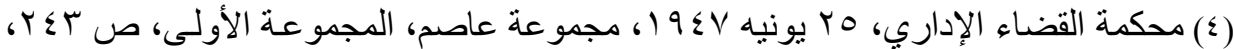

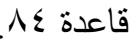

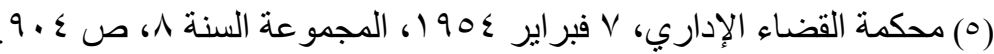


ومـن التطبيقـات القضائية للمنشورات اللائحية يمكن أن نــكر حكم المحكمة

الإدارية العليا الصادر فى r يناير 199 19، والذي قامت فيه بإلغاء حكم محكمة القضاء الإداري، والأي كان قد ذهب إلى اعتبار منشور رئيس محكمة الجيزة الابتدائية بفرض نظام الميكروفيلم - والذي قرر فيه عدم قبول أيـة مستندات أو أوراق في الدعوى إلا بعد التحقق من تصويرها ميكروفيلمياً وختمها بـالختم الخـاص بذلك مـع مطالبة السادة الرؤساء والقضاة بالمحكمة بمر اعاة ذلك والتتبيه على أمنـاء السر بذلك وكذا التبيـه عليهم بعدم تمكين أي فرد من الإطلاع على ملفـات القضايا بحيث يكون الإطلاع من مركز الخدمة الميكروفيلمية فقط ـ من قبيل التعليمات الداخلية الموجهة إلى موظفي المحكمة لتنظيم العمل فيها وبهـذه المثابـة فإنـه لا يرقى إلى مرتبـة القرارات الإداريـة الجائز الطعن فيها بدعوى الإلغاء ـ وقد استتدت المحكمة الإدارية العليا في رفضها لهذا

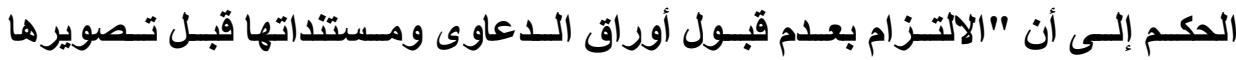
ميكروفيلمياً يكون في حقيقته إنشاء قيد جديد على رفع الدعوى لـ يرد بـه نص في

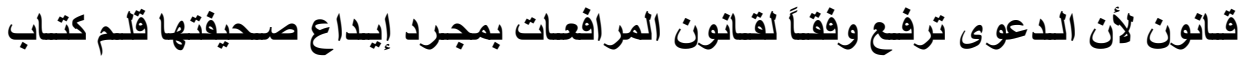
المحكمة بعد أداء الرسم المقرر قانوناً ولا يجوز لقلم الكتاب سواء من تلقاء نفسه أو بقرارات وتعليمـات مـن رئيس المحكمة سـواء بصفة تنظيميـة عامـة أو بصفة فرديـة التقاعس عن قيد الصحيفة مادامت قد استوفت اشتراطاتها المقررة قانوناً .. ويكون الإفصاح عن الإرادة الملزمـة الصـادرة مسن رئسيس المحكمـة سـواء صـاغها في شـكل منشور أو تعليمات أو أوامر إدارية في حقيقته قرار إداري تنظيمسي ممـا يخضع لرقابـة المشروعية أمام مجلس الدولة "( (1)، وكذلك أيضا حكمها الصادر في ه نوفمبر 1900 


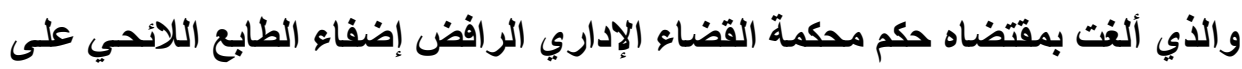

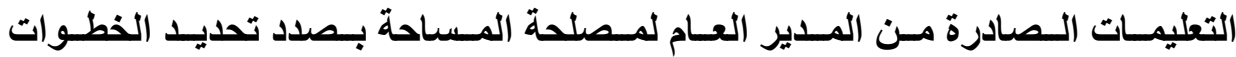

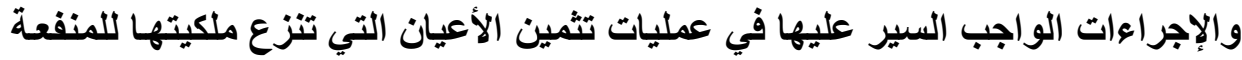

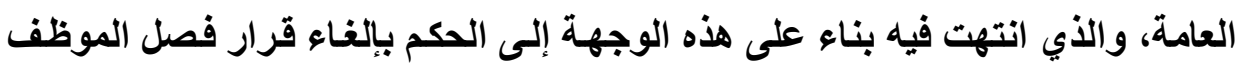

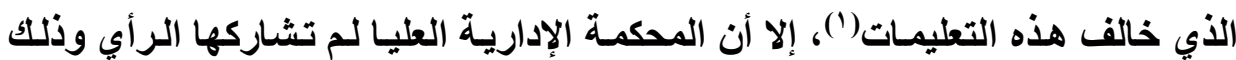

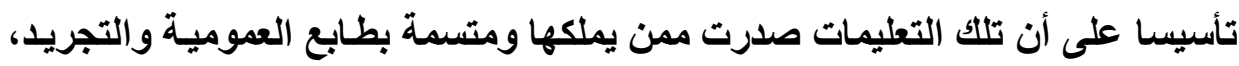

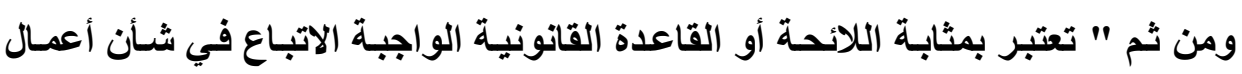

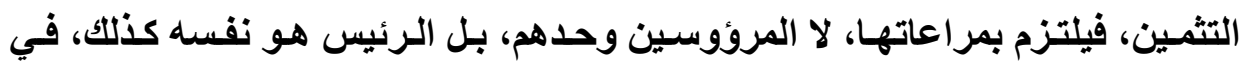
التطبيق على الحالات الفردية طالما لم يصدر منه تعديل أو إلغاء لها بنفس الأداة، أي بقرار تنظيمي عام مماثل، لا في تطبيق فردي قصرا عليه"(").

\section{الفرع الثاني}

\section{الصعوبات التي يثرها التقسيم في التطبيق}

لا شكك أن تقسيم المنشورات إلى تفسيرية ولاتحية، واعتمـاد القاضي الإداري

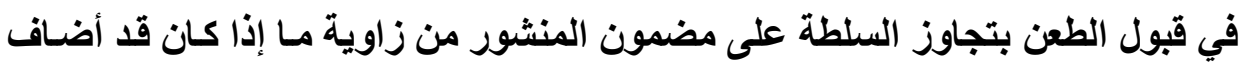
جديداً من عدمه، كان يمثل في نظر القاضي أفضل الحلول بالنسبة لمسألة قبول الطعن

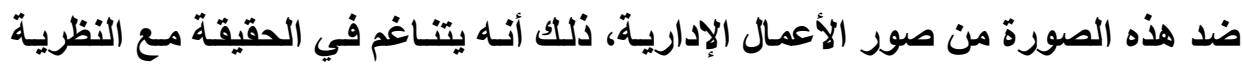

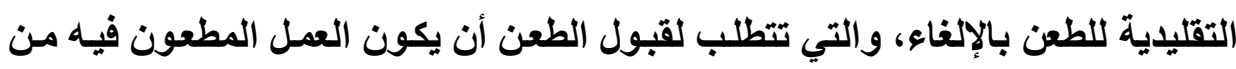

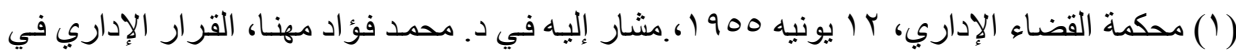

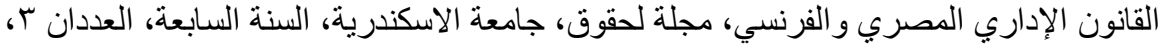


شأنه إحداث آثار قانونية، بمغنى أن يكون من شـأنه التأثير مباشرة في الأوضـاع أو المراكز القانونية (')، سواء بفرض التزامات جديدة أو ترتيب حقوق جديدة، ولهذا كان من المنطقي أن يقوم المجلس بإضفاء الطابع اللانحي على المنشور وإخضاعه لمـا

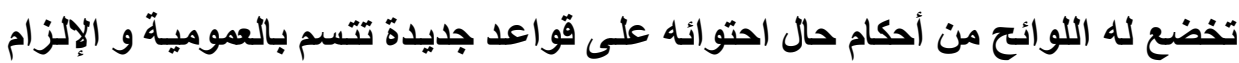
pourvue d'une force obligatoire القانونية modifie L'ordonnancement juridique أو النظام القانوني القائم

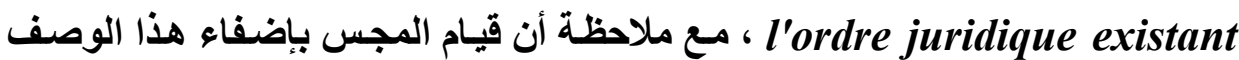

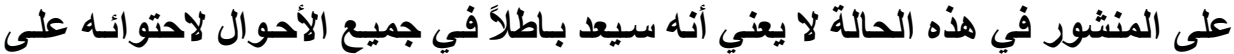

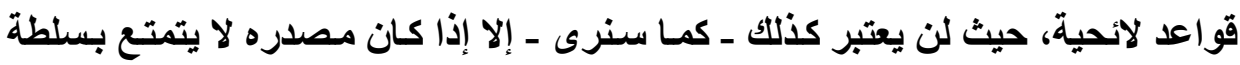
إصدار قرارات لاتحية، أو كان يتجاوز حدود سلطته اللائحية، أو كان مخالفاً للقانون،

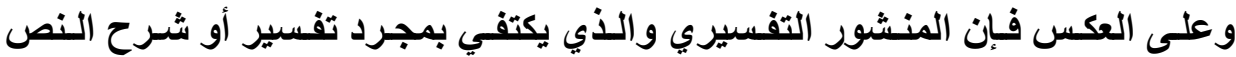
التشريعي أو اللانحي دون إضـافة sans rien y ajouter، أى لا يتضمن تعديلاً في الحقوق والالتزامات الناجمة عن النصوص التي يتم تفسيرها ، فإنها لا يمكن أن يكون محلاً للطعن بالإلغاء، كما لا يمكن أيضاً الاحتجاج به في مواجهة الأفراد، أو الدفع بعدام مشروعيته من جانب هؤلاء (")، ويسري نفس الحكم حتى وإن كان يضيف جديدا -

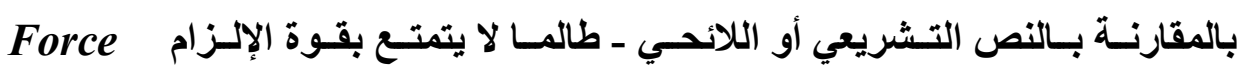

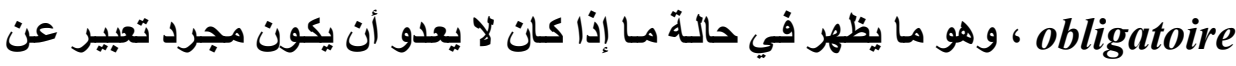
naturelles du bassin inférieur du Doubs, Rec .p. 8 ; - 27 mai 1987, Arnaudies, Rec .p. 187.

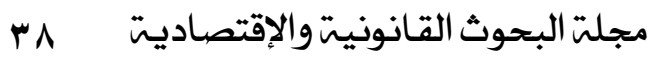




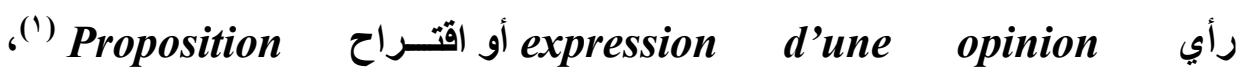

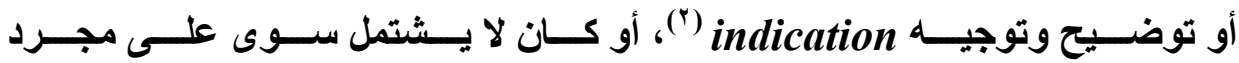
توصيات أو نصائح Recommandations (")، أو يكتفي بمجرد التذكير بقرار سبق

CE 23 janv.1943 Prud'homme, Rec. p. 20.; CE Sec. ler fevr. 1978, , (1) (1) Garrigue, Rec. p. 677; CE 10 juill. 1995, Association "Un Sysiphe », Lebon 292 ; AJ 1995.644, concl. Schwartz ; DA févr. 1996, note Lajartre ; JCP 1995.II.22519, note Ashworth.

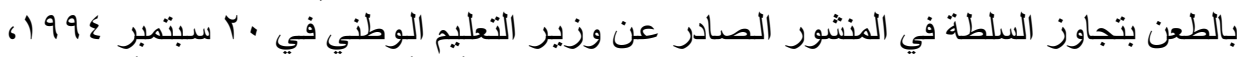

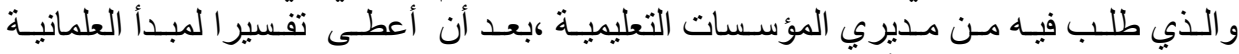
Principe de laïcité

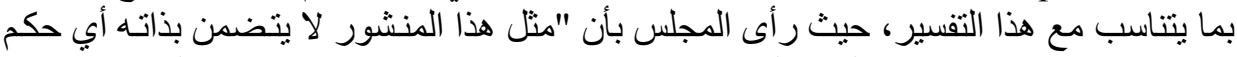

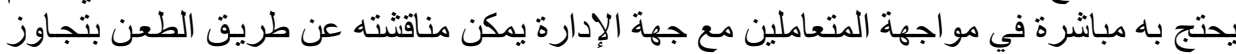
السلطة".

"une telle instruction ne contient, par elle-même, aucune disposition directement opposable aux administrés susceptible d'être discutée par la voie du recours pour excès de pouvoir".

$$
\text { وفي مصر راجع على سبيل المثنال: }
$$

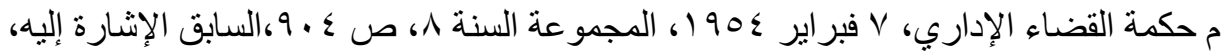

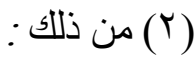

CE 18 nov. 1987, GISTI, Rec. P. 528 ; CE 5 juin 1989, Syndicat national de l'enseignement de l'éducation physique et sportive, Rec. P. 434 ; CE 26 oct. 1992, Min. Éducation nationale, jeunesse et sports Rec. P. 662 ; CE 16 févr. 1996, Société Ares et Iri Software, Rec. P. 666 : information " à titre indicatif"

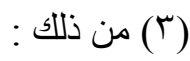

CE 28 juin 1950, Institut Prophylactique, Rec. p. 481; CE, 26 nov. 1965, Compagnie industrielle de textiles artificiels et synthétiques, Rec. p. 642 Sect., 2 déc. 1966, Marchand et autres,Rec. p. 632; CE 4 juill. 1986, Syndicat national des enseignements secondaires et autres, Rec.p. 185; CE 25 avr. 1994 , Min. Éducation nationale, Rec. p.189; CE, sect., 6 mai 1996, Association= 
Souhaits ou اتخـاذه (')، وكـلك أيضا إذا كـان لا يعدو مجرد تعبير عن أمنيـة (r) voeux

الإدارة القيام به مستقبلاً (").

غير أنه إذا كان الاعتمـاد على "معيـار الإضـافة أو الاستحداث في التمييز بين

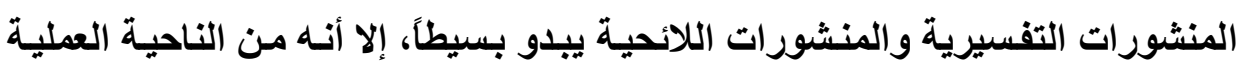

يثير في الحقيقة العديد من المشاكل، ذلك أنه قد يصعب في كثير من الأحيان التأكد ممـا إذا كان المنشور يقتصر على مجرد التوضيح أو التعليق أم أنها أضـاف أحكامـا جديدة، وهو ما عبر عنه الأستاذ شابي Chapus بقوله" بين التعليق الواضـح على القانون، وتشييد أو إضـافة بعض القواعد الجديدة، فِإن هنـاك العديد مـن الحسالات الحديـة"(؛)"،

= Aquitaine Alternatives, Rec. p. 145 ; CE 10 mai 1996, Fédération nationale des travaux publics et autres, Rec. p. 164; CE 18 oct. 2000, Association Promouvoir, RFDA 2000. p.1372.

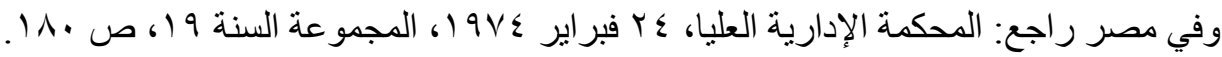

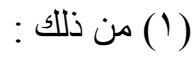

CE 11 avril 1951, Fédération nationale de fabricants de vêtements masculins, Rec. p. 184, op.cit.

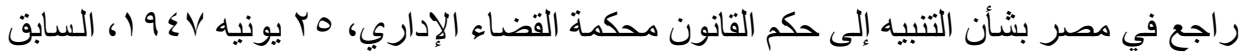

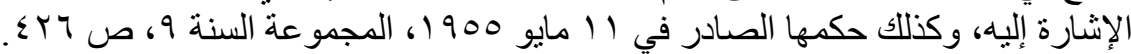

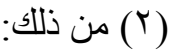

CE, Ass., 15 avr. 1996, Syndicat général des hospitaliers de Bédarieux, AJDA 1996, p. 366, chr. Stahl et Chauvaux, RFDA 1996, p. 1169, concl Combrexelle.

CE 26 mai 1989, Mme Marabuto, Rec. p.434.

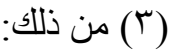

(4) "Entre le commentaire évident de l'état du droit et l'institution certaine de règles nouvelles, les cas limites sont nombreux".

Chapus R., Droit administratif général, tome 1, op. cit., p. 459.

مجلت البحوث القانونيت والإقتصاديت 
ولهذا فإن أحكام مجلس الدولة الفرنسي تباينت في هذا الخصوص، بل وكثيرا مـا حدث اختلاف في وجهات النظر بينه وبين مفوض الحكومـة بشأن تحديد طبيعة المنشور

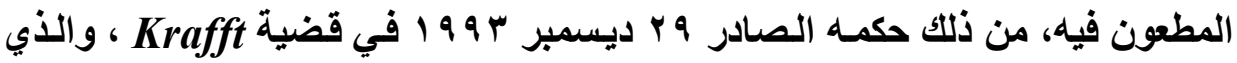
انتهى فيه إلى رفض قبول الطعن بتجاوز السلطة في منشور وزير العدل الصادر في

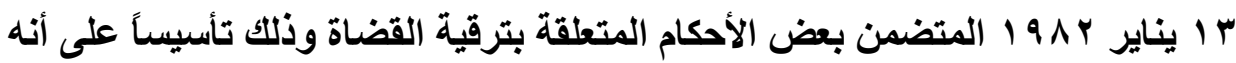

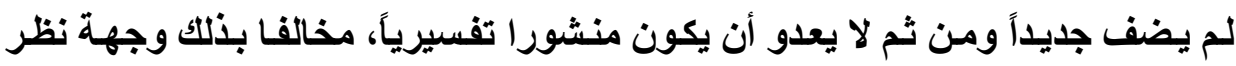

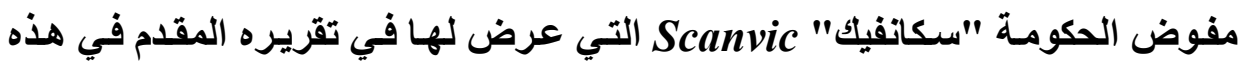
القضية، والذي كان قد انتهى فيه بعبارات حاسمة إلى أن هذا المنشور يعد منشور لائحي وذلك نظرا في تقديره لكونه دون أدنى شك قد أضاف

جديدا للقانون المطبق بثأن ترقية القضاة (') وقد واجـه القضاء الإداري المصري أيضا تلكك الصعوبة، فكثيرا مـا حـدث اختلاف في وجهات النظر كمـا رأينـا بين محكمة القضاء الإداري والمحكمة الإداريـة العليا بثأن تحديد الطبيعة القانونية للعمل المطعون (').

وفي هذا يقول: (1)

"Il ne nous semble faire aucun doute que cette circulaire a ajouté au droit applicable en matière de promotion da magistrats ..." Scanvic F., Concl. sur CE. 29 dèc, 1993, Krafft, JCP 1994, n² 22301. راجع أيضا بشأن اختلاف موقف المجلس عن موقف مفوض الحكومة:

CE 13 janv. 1975, Da Silva et CFDT, Rec.p.16, AJDA 1975. 258, note André, D. 1975. 784, note Julien-Laferrière, Dr. soc. 1975. 273, concl. Dondoux, JCP 1976. II. 18235, note Pellet;- CE 27 sept.1993 Rusti, Dr.adm. 1994, $n^{\circ} 437$, obs.F.S.;- CE. Ass. 2 déc. 1994, Département de la Seine-Saint-Denis, p. 533, AJDA 1995. p. 40, concl, R. Schwartz; RFDA 1995, p. 655, note, Lavialle C.

مجلت البحوث القانونيت والإقتصاديتة إ 
وممـا يزيد الأمر صعوية وتعقيداً، فبان نفس المنشور - وفقا لمعيار التمييزيمكن أن يكون متضمنا لأحكام تفسيرية وأخري لانحية(")، كما أن هذه الأخيرة قد يكون

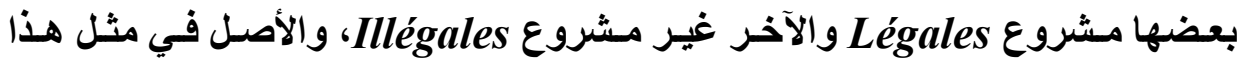
الوضع أن الإلفاء لا ينصب إلا على الجزء الخاص بالقو اعد اللانحية أو الجانب المعيب

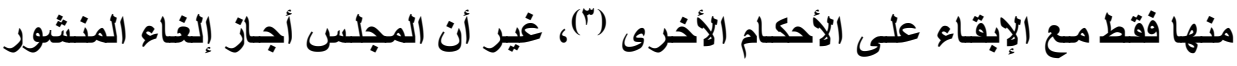

$$
\begin{aligned}
& \text { راجع فيما سبق، ص بـ وما بعدها. } \\
& \text { (Y) راجع على سبيل المثال: }
\end{aligned}
$$

CE Sect. 28 nov. 1958, Lepouse, Rec. , p. 596, D. 1959.263, note Quermonne; RDP. 1959.306, note,Waline M.; AJDA 1958.1.128, chr. Combarnous et Galabert: circulaire du ministre des P. T. T. énumérant les fonctionnaires auxquels est refusé le droit de grève.

$$
\text { ويتطق بمنشور صادر من وزير البريد والاتصالات بشأن حق الإضر اب . }
$$

CE Ass. 23 déco 1959, Freyssinet, UNEF et union des grandes écoles, Rec.p. 707 , S. 1960.227, note Lamarque; AJDA 1960, p.1.43, chr. Combarnous et Galabert .

ويتعلق بمنشور صادر من وزير الحربية يتضمن توجيهات لإدارات التجنيد بشأن تديد وقف التجنيد.

CE. Sect. 8 oct. 1971, Syndicat national des architectes chargés de la construction d'H.L.M. et autres, Rec. p. 585, concl. Vught.

ويتعلق بمنشور صـادر من وزير الاسكان و التعمير بشأن غرامات التأخير الني توقع على المعماريين

CE Ass. 25 oct. 1991, Syndicat national de l'enseignement chrétien C.F. T. C., Rec. 349 , R. D.P. 1992.217, concl. Pochard: AJDA1991, p.885, chr Maugüé et Schwartz; D. 1992, p.136, note F.H.B.

ويتعلق بمنشور يستبعد رسوم الايجار من النقات التي تتحملها البلديات بشأن تسيير مؤسسات

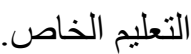

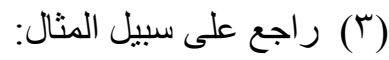
CE 23 octobre1964,Féderation des Syndicats Chrétien de Cheminots, =

مجلتً البحوث القانونيتوالإقتصاديت 
بأكمله dans son ensemble إذا كاتت الجانب اللانحي الذي ثبت عدم مشروعيته لا يمكن فصله عن الأحكام الأخرى التي يتضنها المنشور (').

فضلًا عن ما تقدم فإن مجلس الدولـة الفرنسي في تطبيقهـ لهذا المعيـار أدى في

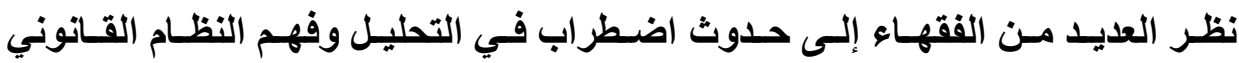

للمنشورات(؟)، وذلك نظراً إلى مـا أظهره من اتجـاه نحو التشدد في إضفاء الطبيعة

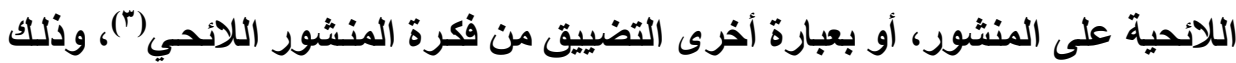
مـن خـلال قيامسه في كثيـر مـن الأحيـان بإضـفاء الطبيعـة التفسيرية على المنشور-

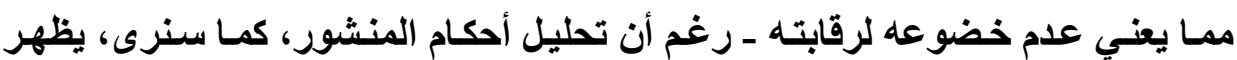
بجلاء بأنه قد أضاف جديداً، وهو النهج الأي يسير عليه أيضاً مجلس الدولة المصري

= RDP1964,p.1210,concl. Bertrand ;- CE 13 janv. 1975, Da Silva et CFDT, Rec.p.16, AJDA 1975. 258, note André, D. 1975. 784, note Julien-Laferrière, Dr. soc. 1975. 273, concl. Dondoux, JCP 1976. II. 18235, note Pellet;- CE 14 janv.1981,MRAP et UNEFRec.p.13,AJDA1981,p.541.

(1)CE, ass.,30 juin 2000,Association Choisir la vie et autres, Rec. P. 249, AJDA 2000. 729, concl. Boissard, D. 2001. 2224, note Legrand, JCP 2000. II. 10423, note Peigné, RFDA 2000. 1305, note Dubouis ; CE ler mars 2006, Syndicat des agrégés de l'enseignement supérieur, Rec. P.888.

(2)" Trouble l'analyse et la compréhension de l'état du droit." Chapus R.,. Droit administratif, général, T. I, op.cit, P.459.

(3)De Laubadère, Traité de droit administrative, op.cit.,p.586; Debbasch Ch.- Ricci J-C,contentieux administratif, 5eme ed., Dalloz, 1990, p. 752; Chapus R.,. Droit administratif, général, T. I, op.cit, P.459; PRETOT X., De l'esprit des circulaires et instructions... et des rapports qu'elles entretiennent avec le droit social », Revue de Jurisprudence Sociale, $n^{\circ}$ 6, juin 1997, p.416.

مجلت البحوث القانونيت والإقتصاديت بـ 
حيث ينحو هو الأخر نحو التشدد في إضـفاء الطبيعة اللائحيـة على المنشورات أو

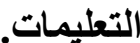

وقبل استعراض الأسباب التي دفعت بالقاضـي الإداري إلى التضييق مـن فكرة

المنشور اللائحس، فإنـه من المفيد الإشـارة إلى مـا حرص مفوض الحكومة "تريكو" على إبرازه في تقريره المقدم في قضية " نوتردام كريسكير"، بشأن مدى Tricot

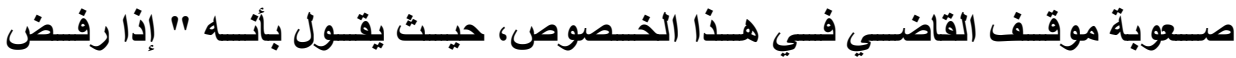
( القاضي) الصفة اللائحية لكل منشور، فإنها يـقص بـلكك من ضمانات المتعاملين مـع جهة الإدارة. حيث يلزمهم في هذه الحالة بالانتظار ريثما يتخذ بشأنهم قرارا فردياً، رغم أن وجه عدم المشروعية قد يكون ظاهرا أو واضـح بالفعل، ومن المناسب أو الملائم مجازاته دون انتظار معاناة أضراره في عدد من الحالات الفرديـة "(')، أي دون انتظار معانـاة الأفراد جراء تطبيقه عليهم، ومـن جهة أخرى "إذا أسـرف في إقرار الطـابع اللانحي، فإنه يقر ويدعم أو يثبت ما لا يعدو أن يكون مجرد إعلان عن اتجاه وتوجيه قابـل للتكيف أو التغيير"()، وهو مـا عبر عنه الأستاذ "ديبـاش" Debbasch في

(1)" S'il refuse le caractère réglementaire à toute circulaire, il réduit les garanties des administrés. Il les oblige à attendre la prise d'une décision individuelle alors que l'illégalité est déjà patente et qu'il serait opportun de la sanctionner sans attendre qu'elle ait sévi dans de nombreux cas particuliers".

Tricot B.,concl.sur CE, Ass.,29 janv. 1954, Institution Notre-Dame du kreiskaer, op.cit, p. 50.

(2)"Mais s'il décide trop souvent qu'il y a règlement, il consacre et renforce ce qui pouvait n'être encore que l'énoncé d'une tendance, une directive susceptible d'accommodement »

Tricot B.,concl.sur CE, Ass., 29 janv. 1954, Institution Notre-Dame du kreiskaer, op.cit, p. 50. 
توضيحه لما ذهب إليه مفوض الحكومة بقوله بأن " التسليم بالطابع اللانحي لمنشور

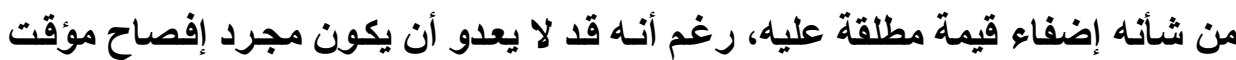

ورجوعاً إلى التساؤل الذي طرحناه بشأن الأسباب التي وقفت وراء التشدد من جانب مجلس الدولة الفرنسي في الاعتراف بالطابع اللاتحي للمنشور، فِإن هنـاك شبه

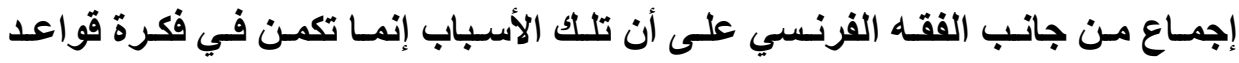
الاختصاص في مجـال السلطة اللائحيـة، ذلك أن الغالبية العظمى من المنشورات إنمـا

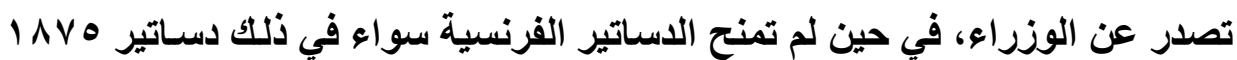
أو دستور 79 أو وأيضاً الاستور الحسلي لعام 1901 19 الوزراء ـ على عكس رئسيس الدولة ورئيس الوزراء - أيـة سلطة لائحيـة عامـة(؟)، فلا يستطيع الوزراء من حيث المبدأ اتخاذ أية تدابير عامة عن طريق قرارات لاتحية إلا بنص في قانون أو مرسوم يسمح لهم بذلك(")، ومن ثم فإن التوسع في قبول الطعن ضد المنشورات سـوف يؤدي

(1)"L'admission du caractère réglementaire à l'effet de donner une portée absolue à une circulaire qui n'est peut-être qu'une manifestation toute provisoire de la volonté administrative"

Debbasch Ch.- Ricci J-C ,contentieux administratif, 5ème éd., Dalloz, 1990, p. 752.

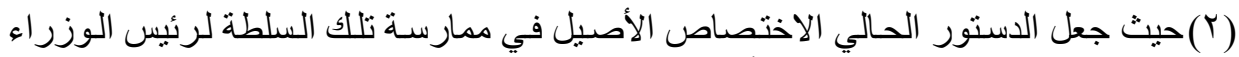

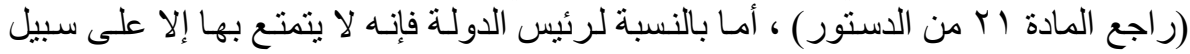

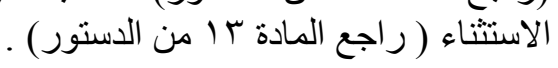

(3) De Laubadère, Traité de droit administrative,op.cit, p.519; Long M. et autres, Les grands arrêts de la jurisprudence administrative, $10 e$ édition, Sirey, 1993,p. 297.

$$
\text { راجع أيضا حكم مجلس الدولة الفرنسي: }
$$

CE. 6 mars 1959, syndicat des grandes pharmacies, Rec. p.164.=

مجلت البحوث القانونيت والإقتصاديت ـ 
بالقاضي: إما إلى القيام بتعديل قواعد الاختصاص(')، وهو مـا لا يملكهـ ذلك أنها تعود للسلطة التأسيسية، أو إلى إبطال عدد ضخم أو هائل من المنشورات بسبب عدم تمتع مصدر ها غالباً بالسلطة اللائحية)()، وهو ما قد يعرقل دون شكك نشاط جهة الإدارة .

Jamart "جيح أن مجلس الدولة الفرنسي بمقتضى حكمه الشهير "جامسار

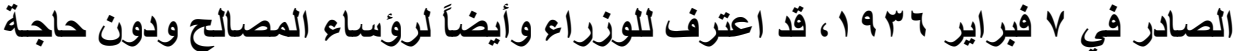
إلى نـص، بسلطة لائحيـة إلا أنـه حصرها في التـابير الضضرورية أو اللازمسة لتنظيم وحسن سير الإدارات أو المرافق الموضوعة تحت سلطتهم، حيث ذهب إلى أنه "حتى في الحالات التي لا يستمد فيها الوزراء سلطة لائحية من أي نص تشريعي، فلهم شـأن كل رؤســاء المـصالح اتخـاذ التـابير أو الإجـراعات الضضرورية لحسن تسبيير الإدارة الموضوعة تحت سلطانهم " (")، ممـا يعنس أن مـا اعترف بـه مجلس الدولـة للوزراء

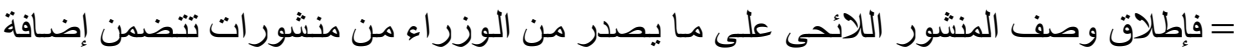

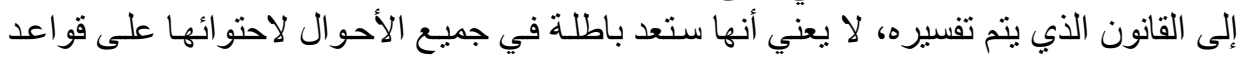

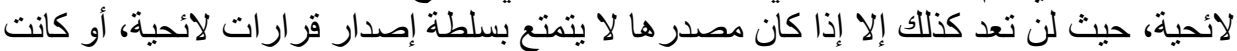

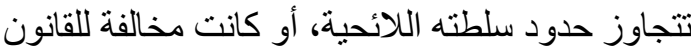

(1) Petit J., Les circulaires I eneral】 ies sont des actes faisant grief, op.cit, p.510.

(2) Petit J., , op.cit, p.510 .

(3) " même dans le cas où les ministres ne tiennent d'aucune disposition $\square$ eneral】 ies un pouvoir réglementaire, il leur appartient, comme à tout chef de service, de prendre les $\square$ eneral】 $\square$ eneral $\square$ ies au bon fonctionnement de l'administration placée sous leur autorité"

7 février 1936 , Jamart, Rec. p. 172, S.1937.3.113, note Rivero.

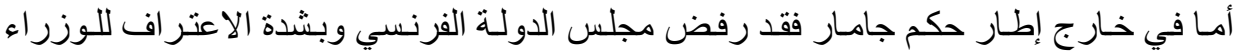

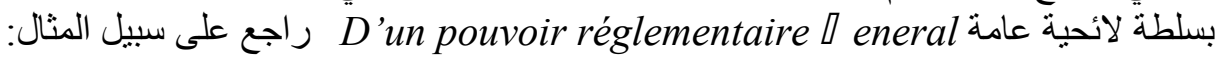
CE, 6 oçt. 1961, Société Duchène,Rec. p. 548; AJDA 1961, p. 640; CE. 6 oct. 1961, UNAPEL., Rec. p. 550; RDP 1961, p. 1271, concl. M.= 
ورؤسـاء المصالح من سـلطة لائحيـة دون حاجـة إلى نص يقتصر فقط على التـابير

العامة المتعلقة بالتنظيم الداخلي للمرفق (")، ومن ثم لا يجوز من خلالها إنشاء حقوق لمق دون

=Bernard; CE. 20 mai 1966, Dhiser., Rec. p. 342 ; AJDA 1966, p. 548; JCP 1966, n, 14889, note C. Gabolde; CE. 7 juin. 1978. Jonqueres d'Oriola,Rec. p. 300; RDP 1979, p. 546, concl. M. Rougevin-Baville; CE. 8 nov, 1991, Le Ruyet,Rec. p. 389.

وذلك رغم دعوة بعض مفوضي الحكومة للمجلس بوجوب الاعتر اف لهم بهذه السلطة استجابة

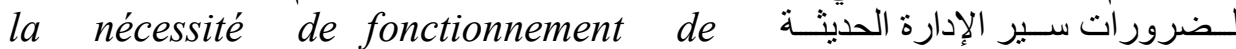
l'administration moderne

Questiaux N., concl. sur CE. 23 mai 1969, Société Distillerie Brabant, AJDA 1969, p. 643.

$$
\text { (1) (1) راجع على سبيل المثال: }
$$

CE. Sect., 29 décembre 1995, Synd.National des personnels de préfectures, Rec. p. 459;- CE 30 juin 2000, GISTl, Rec. CE, p. 260.:

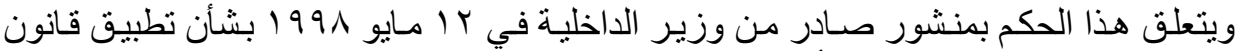

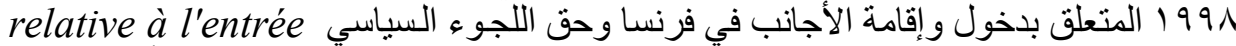
في حيث رأي المجلس

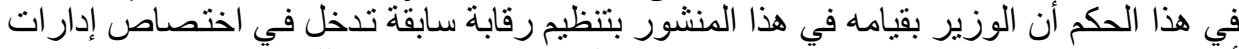

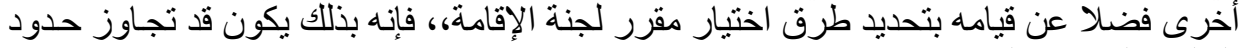

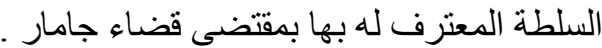

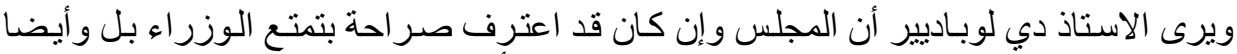

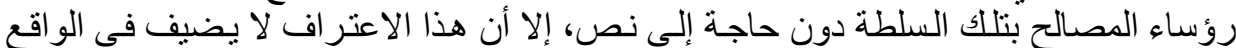

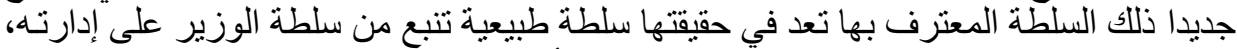

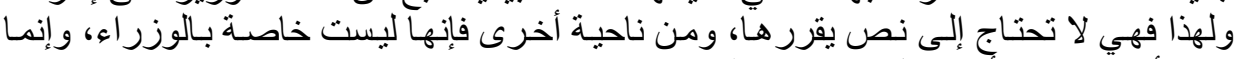
يجب أن يتمتع بها أبضا كل رئيس مصلحة.

De Laubadère, Traité de droit administrative, Op.cit, p.520.

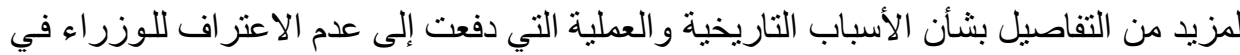
فرنسا بسلطة لائحية عامة راجع:

Moreau $F$., Le règlement administratif, étude théorique et pratique de droit public français, Paris 1902,384 et s.

Douence J.C., Recherches sur le pouvoir réglementaire de l'administration, LGDJ,1969,op.cit., p. 308. 
أو فرض التزامات على المواطنين أو المتعاملين مع الجهات الإدارية(').

فالرغبة إذن في معالجة عدم تمتع الوزراء ورؤسـاء المصالح أساسـا بالسلطة

اللائحية هي من دفع بالقاضي الإداري- في نظر الفقه الفرنسي- إلى تبني مفهوم ضيق

للمنشور اللائحي أو إلى الميل بصفة عامة نحو التثدد في إضفاء الطبيعة اللائحية على الثى المنشورات، وفي المقابل إلى التوسع في مفهوم المنشور التفسيري.

وفي هذا يقول الأستاذ Douence " أن قواعد الاختصاص في مجال السلطة اللائحية كاتت تقف باستمرار وراء صعوبة تطبيق النظرية العامة للأعمال الإدارية على ملى المنششورات، حيـث دفعـت هـذه القواعـد بالقاضـي الإداري إلـى تبنـي حــول خاصـة

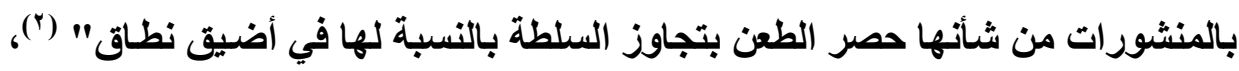

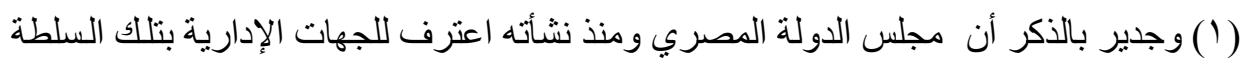

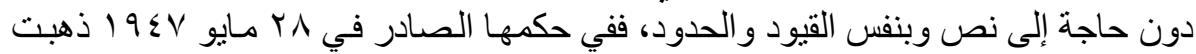

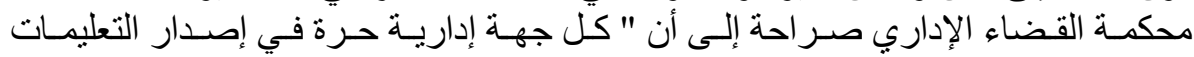

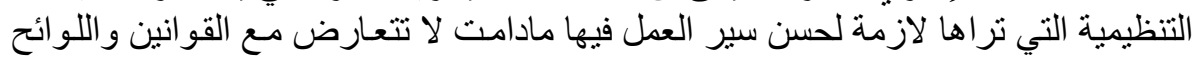

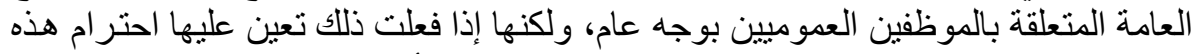

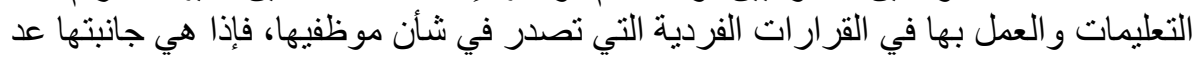

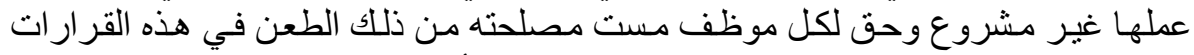

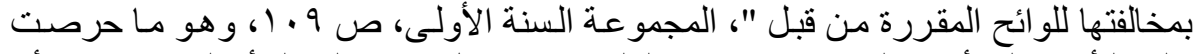

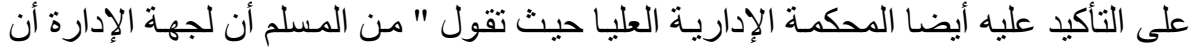

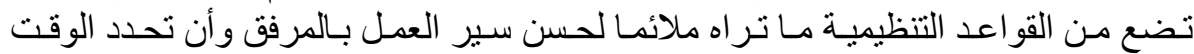

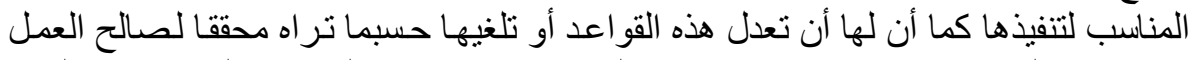

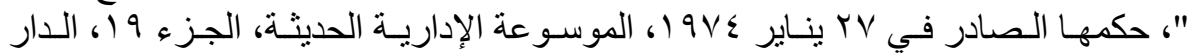

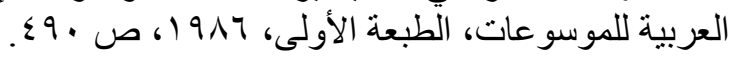

(2)" L'application aux circulaires de la théorie générale des actes administratifs a constamment été gênée par les règles de compétence en matière de pouvoir réglementaire. Ces dernières ont contraint le juge administratif à adopter des solutions propres aux circulaires et restrictives des possibilités de recours".

مجلة البحوث القانونيت والإقتصاديت ـ 
خاصة في الأحوال التي يقدر فيها المجلس بأن المنثور وإن كان قد أضاف جدياً إلا أن

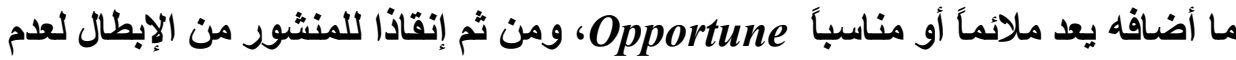
اختصاص مصدره، فإنه يقوم بإضفاء الوصف التفسيري عليه(')

وإذا كان مفوض الحكومة "فورنيه" fournier في تقريره المقدم في قضية مارشاند Marchand قد عمل على إبراز هذا التثدد من جانب المجلس إلا أنتا لا نتفق

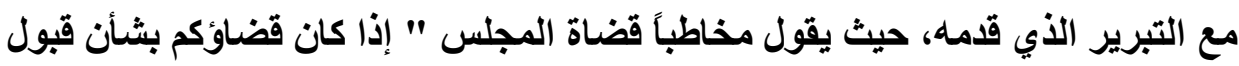
الطعون الموجهة ضد المنشورات يعد في معظم الأحيان قضاء مضيقا، فإن هذا لا يعزي

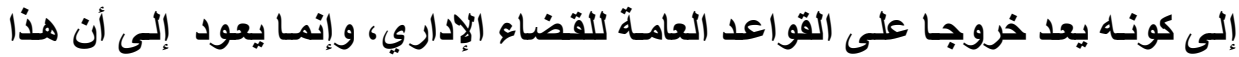
الأخير بصدد تطبيق هذه القواعد يميل في حالة الثكك إلى جعل التوازن في صـالح

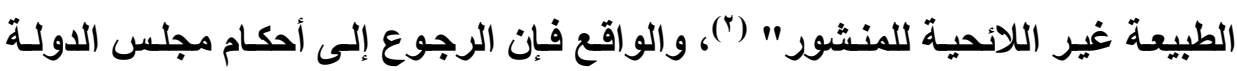
الفرنسي يظهر بجلاء أن تثدد المجلس لا يقتصر فقط على الحالات التي قد يختلف فيها الرأي أو يثور الثُك حولها كما يثير مفوض الحكومـة fournier، ذلك أنه في العديد

Douence J.C., Recherches sur le pouvoir réglementaire de l'administration, op.cit, p. 309 et s.

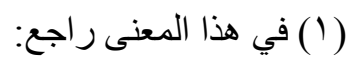

Chapus R.,. Droit administratif, général, T. I, op.cit, P.459.

(2)" Si votre jurisprudence sur la recevabilité des recours diriges contres les circulaires est le plus souvent considérée comme restrictive. Ce n'est pas, parce qu'elle déroge aux règles générales du contentieux administratif. C'est seulement parce que dans l'application de ces règles, et lorsqu'un doute apparait. Elle incline à faire pencher la balance en faveur du caractère non réglementaire de la circulaire".

FournierJ., Concl. sur CE. Sect. 2 décembre 1966,Sieur Marchand et autres, Rec. p. 632,, RDP 1967, P. 562. 
من الأحكام التي انتهى فيها إلى رفض قبول الطعن استتاداً إلى الطبيعة غير اللانحية

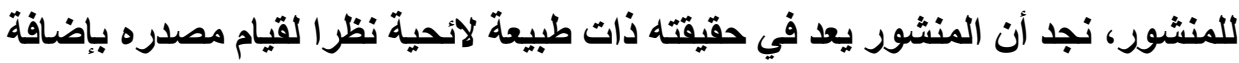

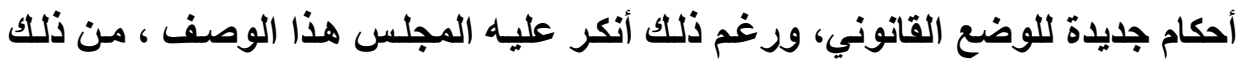

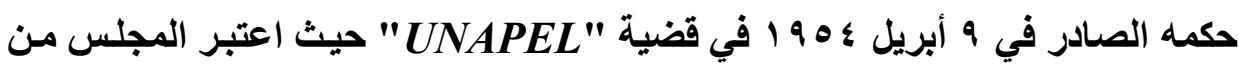
قبيل التفسيرية تلك المنشورات التي صدرت عام 1901 و و عام به 19 19 بشأن تطبيق القانون المسمى قانون بارانجيه Barangé

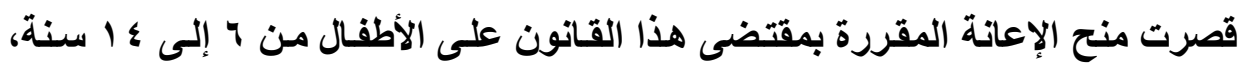

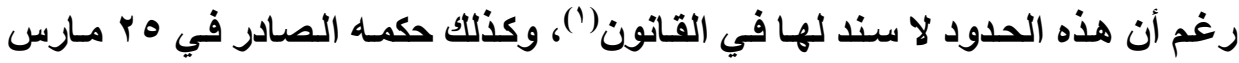

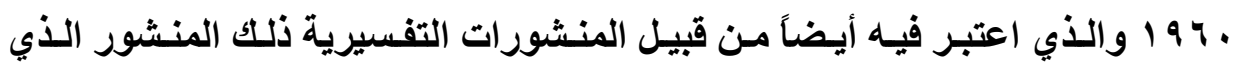

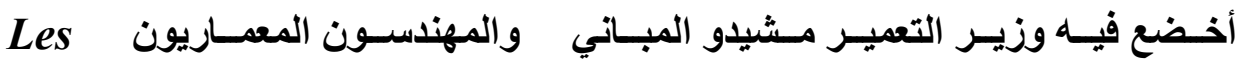
constructeurs et les architectes يمكنه الإفادة من قروض التعمير(")، كذلك أيضا رفض المجلس في حكمه الصادر في با 1 يوليه r 197 في قضية أرنو Arnaud إضفاء الطابع اللانحي على منشور وزير

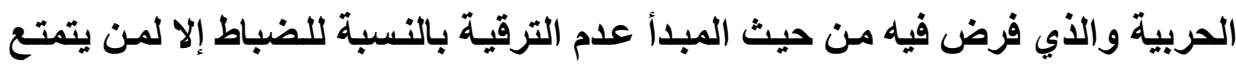
بأقدمية معينة ancienneté minimum في وظيفة ضابط، في حين أن المعيار الذي كان يطبق فيما مضي كان يربط الترقية بالحد الأدنى للسن l'âge minimum حيث اعتبر المجلس أن مثل هذا المنشور لا يعدو أن يكون مجرد توجيهات عامـة

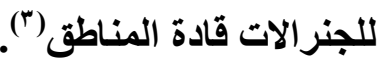

(1)CE. Ass. 9 avr. 1954, UNAPEL,Rec. p. 224.

(2)CE. 25 mars 1960, Confédération générale de. architectes français et Tournon, Rec. p. 233.

(3)CE. Sect. 13 juill. 1962 Arnaud, Rec. 474; AJDA. 1962.545, chr. Galabert et Gentot

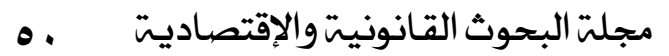


ومن التطبيقات القضائية في مصر يمكن أن نـكر حكم محكمة القضاء الإداري

الصادر في V فبراير ع ه 19 سـالف الذكر والذي رفضت فيه إضفاء الطبيعة اللائحية على خطـاب المدير العـام لمصلحة الضر ائب رغم أن أثره القـانوني واضـح في تقرير إخضاع الصيادلة للضريبة على الأربـاح التجاريـة والصناعية، وكذلك أيضا حكمها

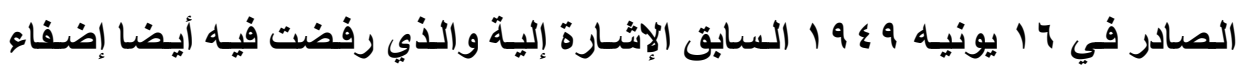
وصف القرار على التعليمات الصادرة من وزارة الصحة والتي بينت فيها الحالات التي

$$
\text { راجع أيضا في نفس الاتجاه : }
$$

CE. Ass. 23 déc 1959, Freyssinet, UNEF et union des grandes écoles, Rec. 707 , S. 1960.227, note Lamarque; A.J. 1960.1.43, chr. Combarnous et Galabert.

ويتعلق بمنشور صادر من وزير الحربية يتضمن توجيهات لإدارات التجنيد بشأن تجديد وقف Renouvellement des sursis d'incorporation التجنيد

-CE 10 juill. 1995, Association "Un Sysiphe », Lebon 292 ; AJ 1995.644, concl. Schwartz ; DA févr. 1996, note Lajartre ; JCP 1995.II.22519, note Ashworth, op.cit.; .

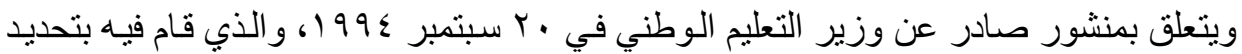

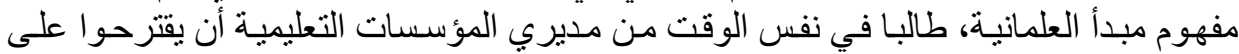

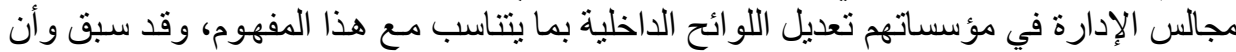

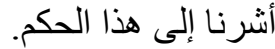
-CE 10 mai 1996, Fédération nationale des travaux publics, Rec. P.164, AJDA 1997.196, note Maljean-Dubois, RFDA 1997.13, concl. Fratacci.

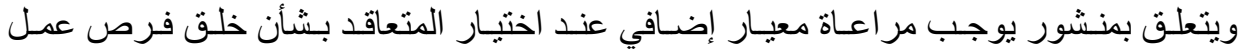

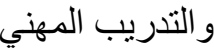
la création d'emplois et à la formation professionnelle حيث اعنبر المجلس أن هذا المنشور لا يعدو أن يكون إعلان عن رغبة العنائ ، وليس معيار للاختيار

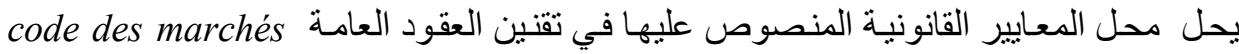
publics

مجلة البحوث القانونيت والإقتصاديت 
تعتبر فيها العقـاقير أو الحاصـلات مغشوشة أو فاسدة وذلكك تأسيسا على أن أثرهـا لا يتعدى المـوظفين المطلـوب مـنهم تنفيذها، رغم أن تأثيرهـا في المراكز والأوضـاع القانونية للأفراد لا يحتاج إلى تدليل، ذلك أنها صدرت بغرض تطبيق مـا تتضمنه على المتعاملين مع جهة الإدارة .

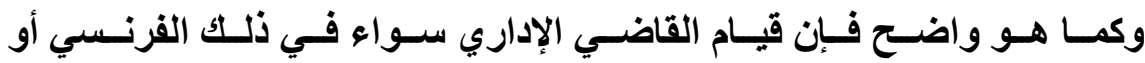
المصري بإضفاء الوصف التفسيري على المنشورات أو التعليمات في القضايا المشار إليها لا ينبع من مضمونها، وإنمـا في الحقيقة من رغبة القاضـي الإداري في الإبقاء عليها. وقد يقـال دفاعـاً عن سياسـة مجلس الدولـة في هذا الخصوص بـأن موقفه يعد نوعاً من السياسة القضائية الحكيمة، حاول فيها المجلس التوفيق بين عدم تمكنه من الاعتر اف للوزير أو رؤسـاء المصالح ـ كمـا ذكرنـا آنفا - بسلطة لاتحيـة عامـة، وبين

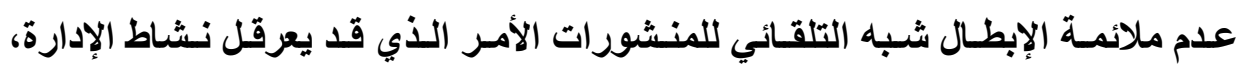
خاصة في الأحوال التي يكون فيها أن المنشور وإن كـان قد أضـاف جديدا بمـا يجـاوز

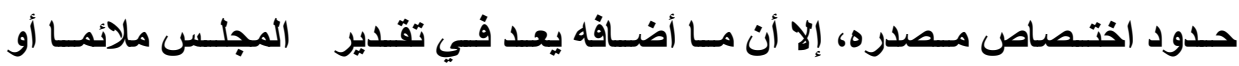

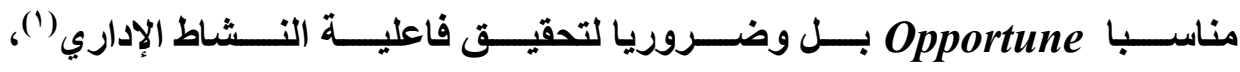
وبالتـالي لمعالجـة الموقف، فإنـه يلجـأ لوصـف المنشور بأنـهـ تفسيري، مخالفـا بـذلك النظرية العامة للأعمال الإداريـة، إنقاذا للمنشور من إبطال حتمي فيمـا لو أعترف لـه بالطابع اللائحي.

( ) و هو ما يتفق مع ما يتبعه القاضي الإداري في كثير من الأحيان عندما يجد أن المقدمات

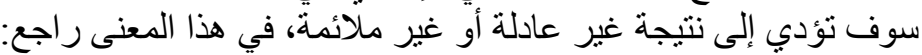

GAUDEMET Y., Les méthodes du juge administratif , LGDJ, , 1972, p.57.

or مجلت البحوث القانونيتوالإقتصاديت 
والواقع رغم نبل الاعتبارات التي تقف وراء تبني مجلس الدولة لتلك السياسة

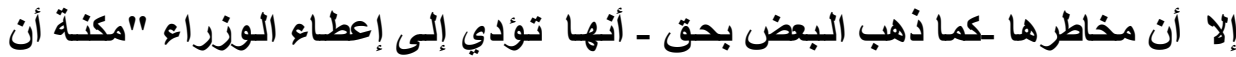

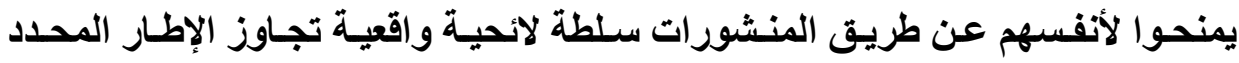

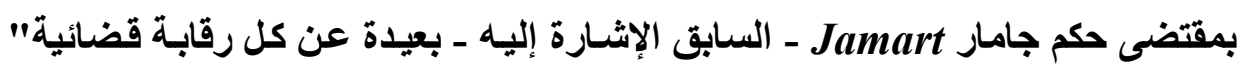

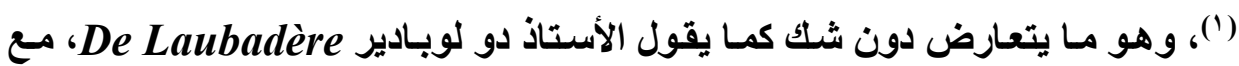

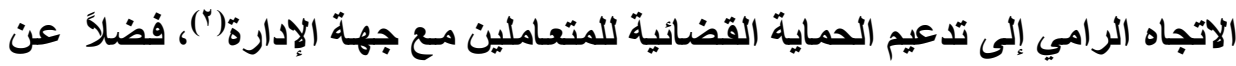

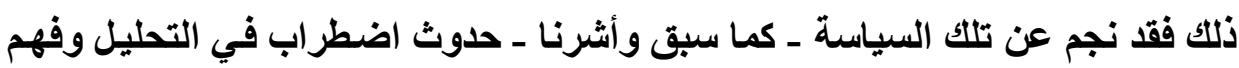

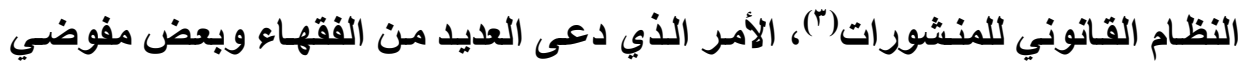

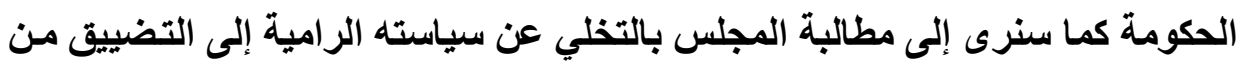

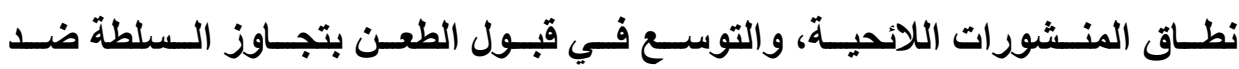
المنشورات()،بل ومطالبته بالتخلي عن معيار "الإضـافة" الذي اعتمد عليه المجلس في التمييز بين المنشورات اللانحية والمنشورات التفسيرية.

(1)"la possibilité de s'attribuer par voie de circulaires un véritable pouvoir réglementaire de fait, dépassant le cadre limité de la jurisprudence Jamart et soustrait à tout contrôle juridictionnel".

Long M. et autres, Les grands arrêts de la jurisprudence administrative, 10e édition, Sirey, 1993,p. 513.

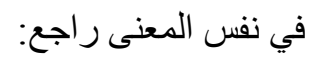

Petit J., Les circulaires impératives sont des actes faisant grief, op.cit, $p$. 510.

(2) De Laubadère, Traité de droit administrative, op.cit., 962,p.586.

(3)Chapus R.,. Droit administratif, général, T. I, op.cit, P.459.

(4) Long M. et autres, Les grands arrêts de la jurisprudence administrative, 10e édition, Sirey, 1993, op.cit ,p. 513.

مجلة البحوث القانونيت والإقتصاديت م 


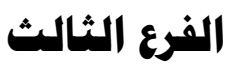

\section{إخضاع المنشورات التفسيرية في فرنسا لرقابة المشروعية}

بطريق غير هباشر " دعوى فمص المشروعية ”

قدمنا أن العقبة الرئيسية بثأن قبول الطعن بالإلغاء ضد المنشورات التفسيرية

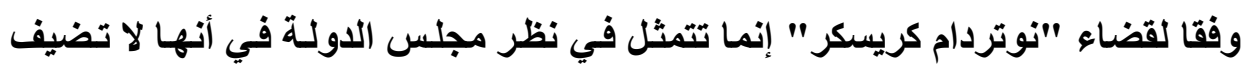

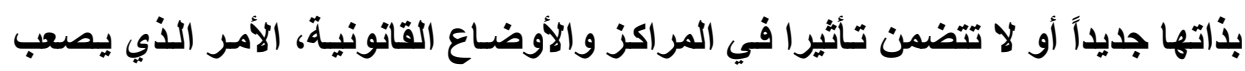

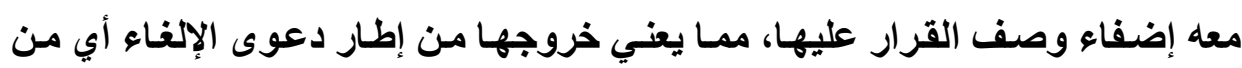

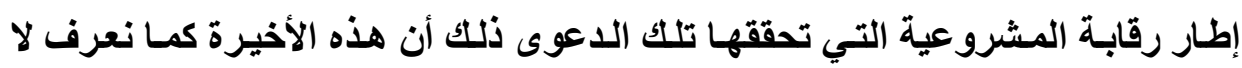
توجه إلا إلى قرار إداري بغرض فحص مش مشروعيته.

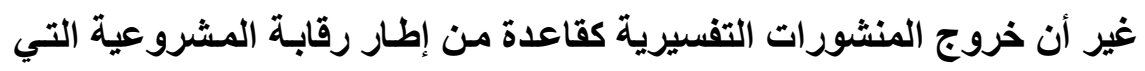

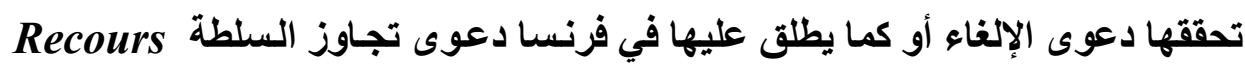
و والتي قد تنتهي بإلغاء القرار محل الطعن إذا مـا تبين

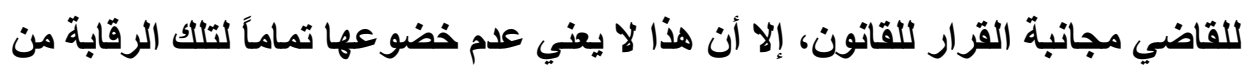

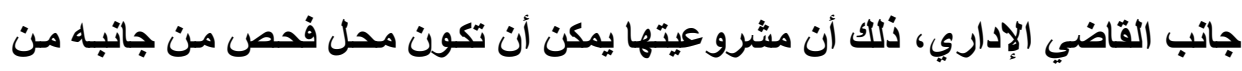

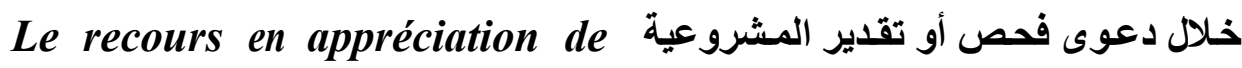

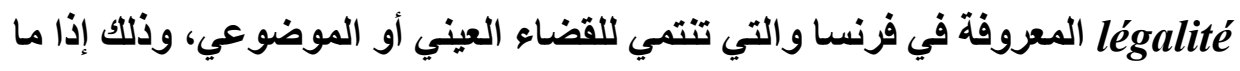

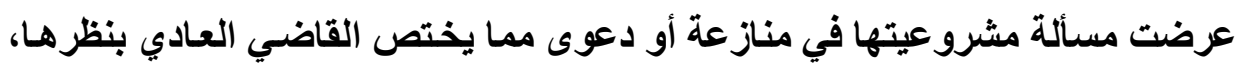

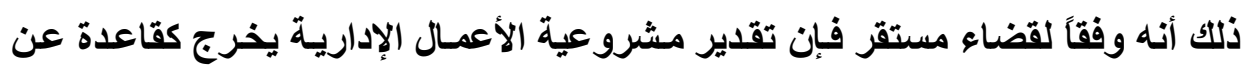

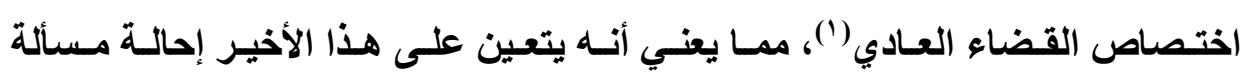

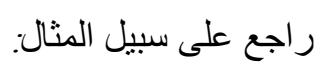

T.C. 4 juin 1910, Abbé Mignon, R.CE, p.442; 16 juin 1923, Septfonds, DP1924, 3, p.41, concl. MaterP., S.1923, 3, p.49, note Hauriou. $=$

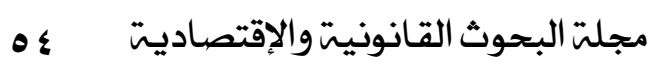


مشروعية تلك الأعمال للقضاء الإداري للفصل فيها، بل وتعتبر هذه القاعدة من القواعد

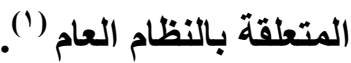

وما اتجه إليه القضاء الفرنسي في هذا الخصوص لا يتعارض في الحقيقة مـع مبدأ الفصل بين القضاء العادي والقضاء الإداري، ذلك أن هذا المبدأ وإن كان يضع حدوداً بين جهتـي القضاء، إلا أنسه لا يـؤثر أو يمس حقيقة أن المنازعـات لبس مـن الضروري أن تكون إدارية بحته أو مدنية بحته، ومن ثم فإن الفصل بين جهتي القضاء يجب أن يكون مصحوباً بقدر من التعاون بينهما حنى يستطيع كل قاض يواجها بمسألة تخرج عن نطاق اختصاصه المباشر أن يطلب من نظيره الإجابـة عنها ، وبالتـالي فإن القاضي الإداري يمكنه أن يطلب من القاضي المدني أن يجيبه عن مسألة أوليه تخرج عن نطاق اختصاصه، وبالعكس يستطيع القاضي المدني أن يطلب من القاضسي الإداري

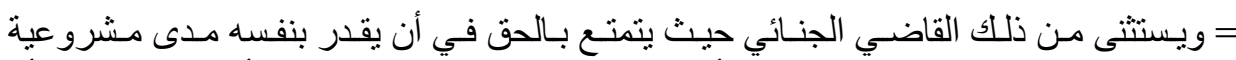

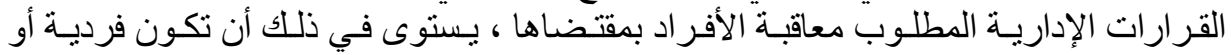

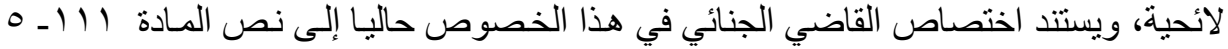

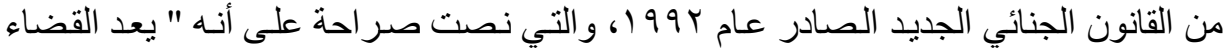

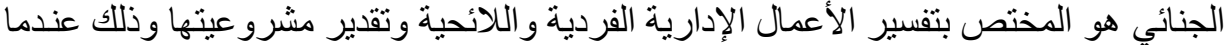
يكون هذا الفحص ضروريا للفصل في الدعوى الجنائية المنظورة"

Les juridictions pénales sont compétentes pour interpréter les actes administratifs, réglementaires, ou individuels et pour en apprécier la légalité lorsque, de cet examen, dépend la solution du procès pénal qui leur est soumis."

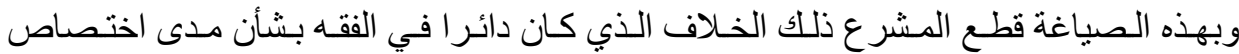

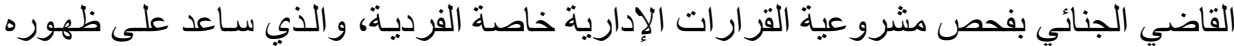
في الواقع تضارب الحلول القضائية في هذا الخصوص، من ذلك: الندانية

T.C. 5 juillet, Avranches et Desmarets; Cass.Crim. 1 juin 1967, Canivet. Chapus R., Droit du contentieux administratif, op.cit, p. 755. ( ) Cass.soc. 3 juillet 1990, Bull.Civ.V,no340. 
فصص مشروعية عمل إداري(')، وهذا هو بالتحديد موضوع دعوى فحص المشروعية. وقد أثار قضاء فحص المشروعية خلافا بين الفقهاء في مصر ، حيث ذهب

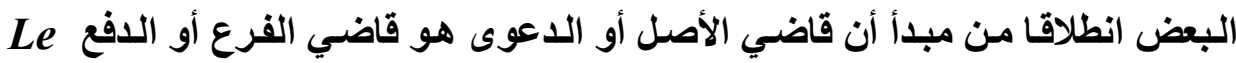

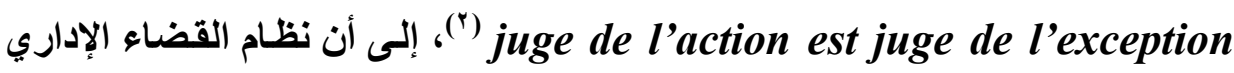
لاينا لا يعرف دعوى فحص المشروعية المجردة عن منازعة يفصل هو فيها نهائيا على النحو المقرر في فرنسا، فهو لا يختص بنظر مشروعية العمل الإداري إذا أثثرت مسألة مشروعيته أمام قاضي آخر، بعبارة أخرى لا يتولى فحص مشروعية أو تفسير

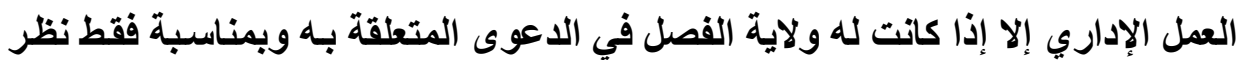
هذه المنازعة، فقحص المشروعية من جانب القاضي الإداري في تقدير هذا الجاتب يستلزم أن يكون مختصاً بالدعوى أساسا وسيفصل فيها نهائيا، وفي هذا يقول الاكتور

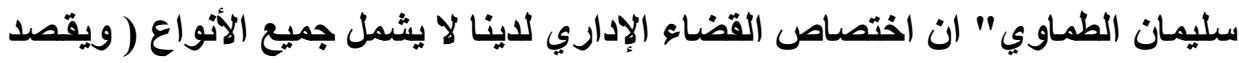

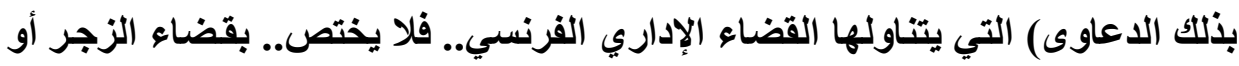

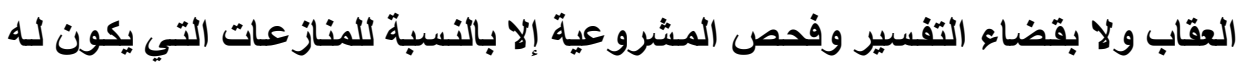

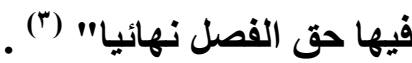

(1) Seiller B., Circulaires et legalite, note sous Conseil d'Etat, 27 mars 1996, M. Lome,op.cit.,p. 1219.

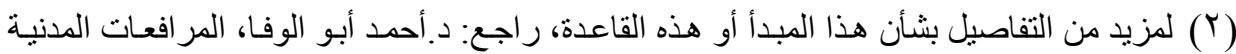

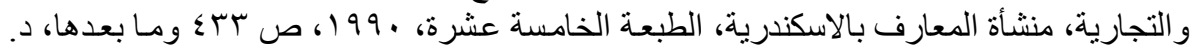

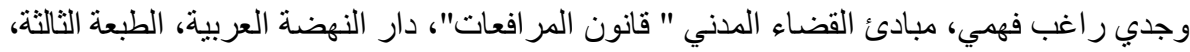

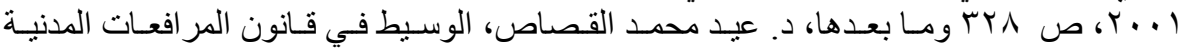

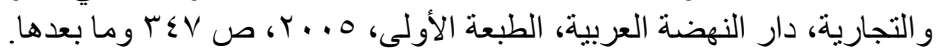

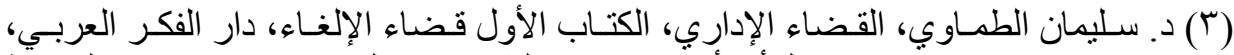

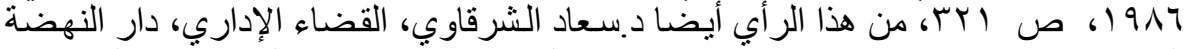

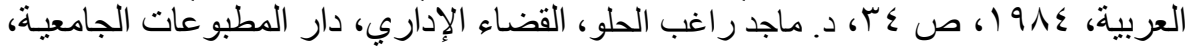


غير أن البعض الآخر وإن كان يسلم بأن المحاكم العاديـة في مصر عندما يثار

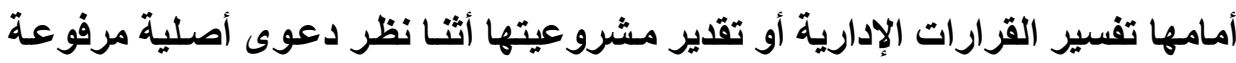

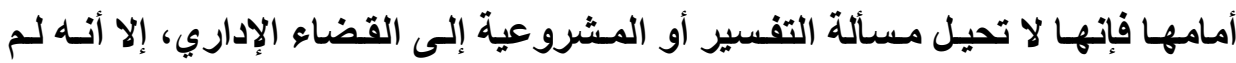

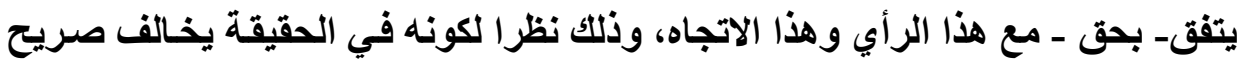

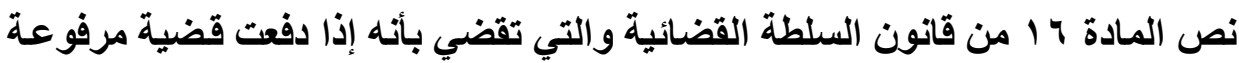

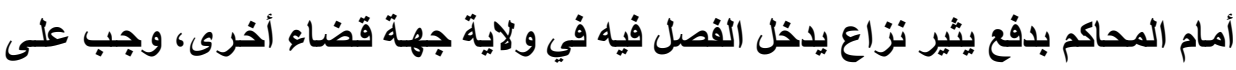

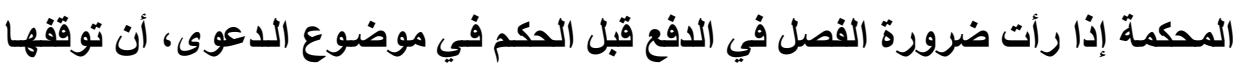

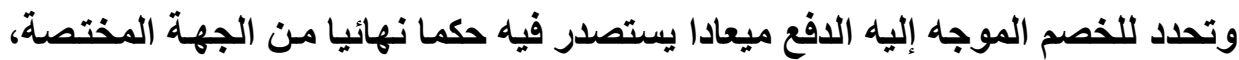
وكذلك المادة V Vن هذا القانون والتي منعت المحاكم العادية صراحة من تأويل الأمر الإداري أو وقف تنفيذه، كما أنه يتناقض مع كون مجلس الدولة أصبح صـاحب الولايـة

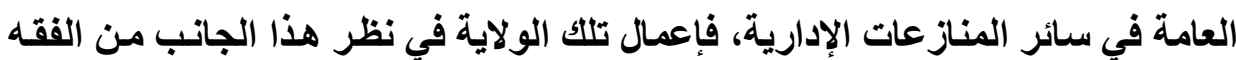

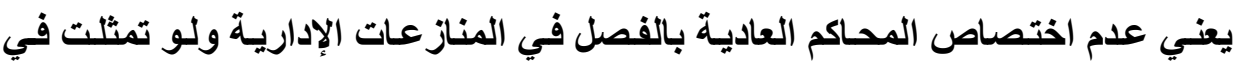

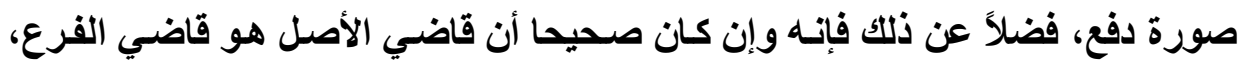

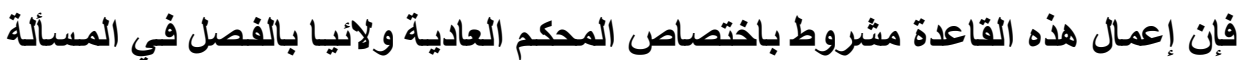
الأولية لو رفعت إليها بصفة أصلية (1)، والواقع فإن ما يذهب إليه هذا الجاتب من الفقه

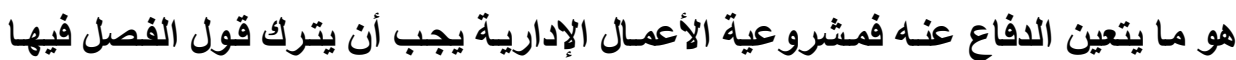
لقاضيها الطبيعي وهو القاضي الإداري.

وترتيبا على مـا تقدم فإنتا سنكتفي باستعر اض السمات العامـة لدعوى فحص أو تقدير المشروعية في النظام القانوني الفرنسي " أولاً "، ثم نعقبهـا بتحليل التطبيق القضائي لهذه الدعوى فيما يتعلق بموضوعنا " ثانياً ".

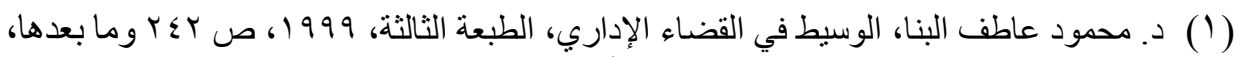

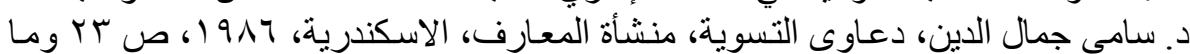

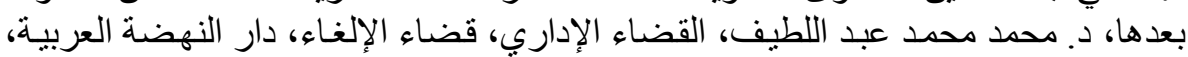




\section{أولاً: السمات العامة لاعوى فعص المشروعية}

contentieux objectif تنتمي دعوى فحص المشروعية للقضاء العيني مثلهـا فـي ذلـك مثل دعـوى الإلغــاء، إلا أنهـا على خـلاف هـذه الأخيـرة تعـد مجـر

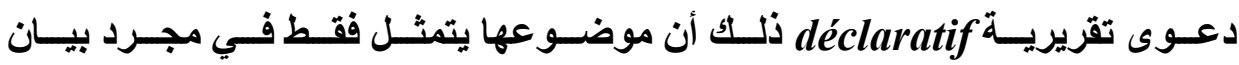
أو إظهـار مـدى مطابقـة عمـل إداري معين للقـانون دون أن يتعـدى ذلــك إلـى إصــار

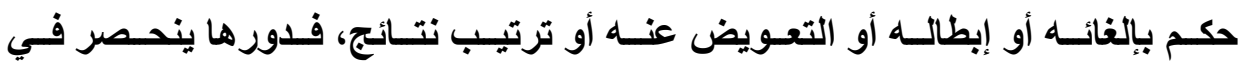

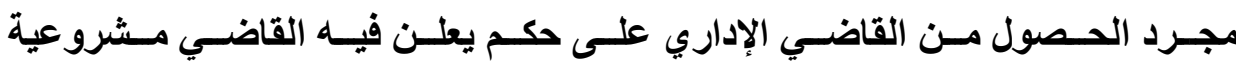
أو عدم مشروعية عمل إداري معين(')، فضلاً عن ذلك فإن جميع الأعمال الإداريـة على يلى خلاف دعوى الإلفاء يمكن أن تكون موضوعاً لهذه الدعوى، حتى وإن كان لا يمكن الطعن فيها مباشرة، يستوى في ذلك أن تكون صسادرة بـالإرادة المنفردة أو بتلاقي إرادتين أي يستوى أن تأخذ شكل العـل الاتفرادي أو شكل العقد (†)، كمـا أنها لا تتقيد بأية ميعـاد فأي عمل إداري مهمـا طال بـه الزمن يمكن أيضـا أن يكون موضوعا لتلك

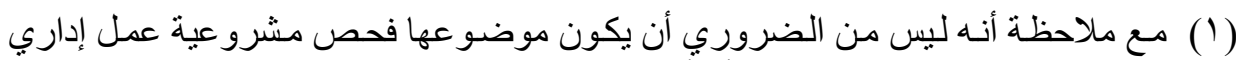
و إنما التحقق من وجود هذا العمل، أوبأنه كان نافذا قانونا في تاريخ معين.

$$
\text { بالنسبة للفرض الأول راجع : }
$$

TC 8 décembre 1969, Safer de Bourgogne,Rec. p.684,; 15 juin 1970, Soc. pour la mise en valeur agricole de la Corse, Rec. p. 890.

$$
\text { وبالنسبة للفرض الثاني راجع: }
$$

CE Ass. 22 janvier 1982, Butin et Ah Won, Rec,p. 33,AJDA 1982, p. 440

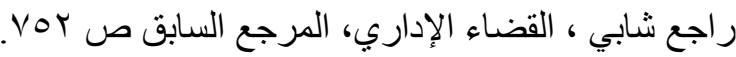

$$
\begin{aligned}
& \text { (r) راجع على سبيل المثال: }
\end{aligned}
$$

C.E. 14 nov. 1924, Chartier. p. 892 ; C.E. 20 janv. 1965, Courvoisier; p. 39. Chapus R., Droit du contentieux administratif, op.cit, p. 751.

$$
\text { مجلت البحوث القانونيت والإقتصاديت }
$$


اللدعوى(')، كمـا أنها وعلى خـلاف أيضا دعوى الإلغـاء تعد دعوى أو طعن عرضسي recours incident حيث يتعين لإمكان تحريكها أمسام القاضسي الإداري أن يثار أمسام القاضسي العـادي بمناسبة دعوى ممـا يختص بنظرهـا مسألة تتعلق بمشروعية العمل لهل الإداري المراد تطبيقه أو المتنازع حوله، فإذا ما قدر بأن المسألة المثارة جدية ولازمـة للفصل في الدعوى فإن عليهه في هذه الحالـة أن يوقف الفصل في الدعوى وإحالـة الخصوم إلى القضاء الإداري لفحص مسشروعية هذا العمل، فتحريك دعوى فحص لـص المشروعية يتوقف إذن على صدور حكم من القاضي العادي يوقف بمقتضاه الفصل في

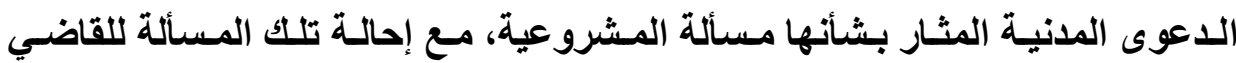
الإداري()، فإذا ما تحقق ذلك فإن اختصاص هذا الأخيز لا يتحرك تلقائيا وإنما يتعين

C.E. 28 avr. 1882, Ville de Cannes,Rec. p. 389;- CE 19 janvier 1973, Femandez, Rec. p. 49;- CE 8 février 1989, cons. Mazières, Rec. p.838 Chapus R., Droit du contentieux administratif, , op.cit, p. 756; Seiller B., L'exception d'illégalité des actes administratifs, Thèse Paris II, 1995, p. 201 et $s$.

$$
\text { بثأن ضرورة وقف الفصل في الدعوى المدنية راجع: }
$$

CE 9 mars 1983, Sarl Garage de Verdun, DA 1984, n" 164.

$$
\text { وبشأن وجوب الإحالة راجع: }
$$

CE 20 mars 1953, Finidiri, Rec. p. 145-CE 15 juillet 1957, Soc. industr. des oléagineux, AJDA 1958, 2, p. 3 ; - CE 16 novembre 1988, Soc. Ritz Hôtel, DA 1988, no 650;- CE 30 juillet 1997, BNP, RFDA 1997, p. 1096. وإن كان المجلس يكتفي بائة صيغة يفهم منها معنى الإحالة فيكفي مثنلا أن يحكم القاضي المداني

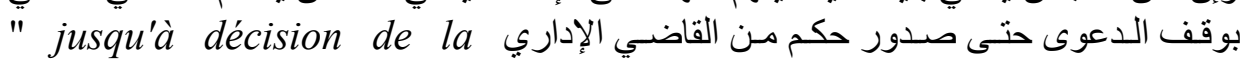
juridiction administrative" CE Sect. 6 février 1981, Mlle Baudet, p.53, Al 1981, p.489, concl. Dondoux $P$. 
على الخصوم أنفسهم تحريك تلك الدعوى أمامه، فلا يجوز لغير الخصوم تحريكهاو أيا كاتت المصلحة المستهدفة (')

إذا توافر هذين الشرطين - صدور حكم الإحالة، وصفة الخصم ـ فإن القاضسي

الإداري يقع عليه التزام بالفصل في الموضوع في حدود بطبيعة الحسال حكم الإحالـة dans les limites du renvoi العـادي للافع أو تقدير جديته أو ضرورته للفصل في اللدعوى المدنية، وهو مـا أكده

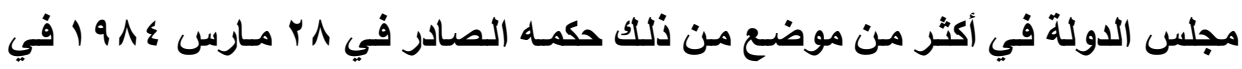
قضية شركة طومسون Société Thomson حيث قرر صراحة بـأن المحكمة الإداريـة

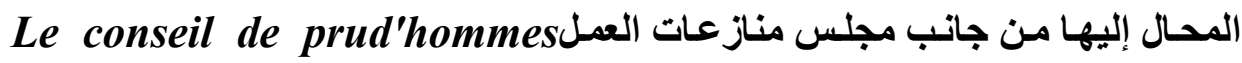
تقدير مشروعية القرار الضمني السامح لشركة "طومسون" بفصل السيد.. باعتبارها

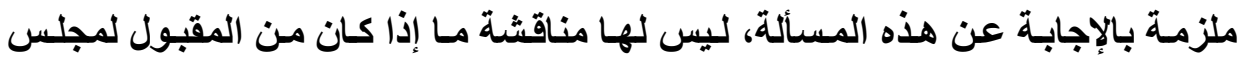

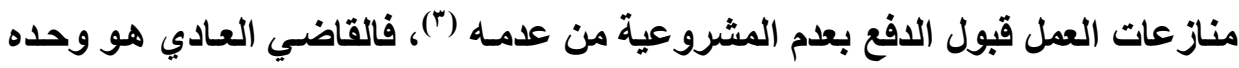

(1) C.E. 10 févr. 1937, Ste. Valrose et Delmas, Rec. p. 174;- CE Sect., 13 juillet 1961, Mme Lauriau, p. 512; Sect. 7 juillet 1995, Mme Wimmer, DA 1995, n? 717;- CE 29 décembre 2000, Beule, p. 656, LPA mai 2001, $n^{\circ}$ 99, concl.. Boissard; S.;- CE 3 février 2003, Paganon, p.907, AJ 2003, p. 1406.

(2)CE 8 janvier 1958, Soc. des courses de la Côte d'Azur, Rec.p.13, AJDA 1958, 2, p.54, concl. Long M.;- C.E. 28 févr. 1964, Commun. de Lacanau, Rec. p. 152;- CE Sect. 3 novembre 1997, Soc. Intermarbres et Soc. Million et Marais, p.393 et 406, concl.. Stahl J.-H, AJ DA 1997, p. 1012, RDP 1998, p.266, RFDA 1997, p. 1228.

(3)" Le tribunal administratif, saisi par le conseil de prud'hommes de Paris de la question de la légalité de la décision implicite autorisant la société Thomson CSF à licencier Monsieur..., était tenu de répondre à cette question : il ne lui appartenait pas de se prononcer sur le point de savoir si l'exception d'illégalité soulevée devant le conseil de prud'hommes était recevable". =

$$
\text { 7. مجلت البحوث القانونيت والإقتصاديت }
$$


المختص بتقدير مدى لزوم الإجابة عن مسألة المشروعية، ومن ثم لا يملك القاضسي

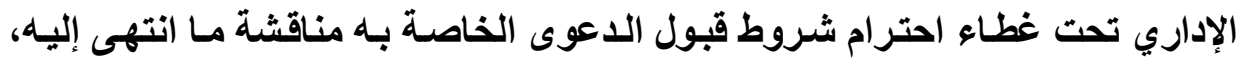
وهو ما حرص على إبرازه الأستاذ لافريير Laferrière ، حيث يقول " إن الحكم بعدم القبول في هذه الحالة لن يكون فقط مناقض للعلاقات التي يجب أن تكون موجودة بلين

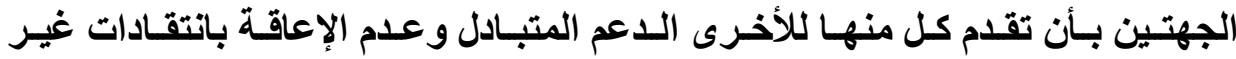
ضرورية، وإنما سيمثل أيضاً تعد على سلطات قاض الموضوع، فهذا الأخير هو وحده

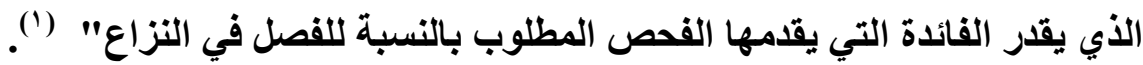
غير أن القاضي الإداري وإن كان ملزما بالفحص إلا أن هذا الإلزام ليس مطلقاً، حيث يملك في الحقيقة رفض اللاعوى إذا كاتت المسألة المطلوب فحص مشروعيتها تخرج عن حدود اختصاصه(ץ)، كذلك يتوقف التزامسه بالفصل في الدعوى إذا مـا تـم

$=$ CE, 28 mars 1984, Société Thomson CSF, DA 1984, $n^{\circ} 241$

CE 17 juin 1977, Le Beux, RDP 1978, p. 288; - CE 28 avril 1961, di Neira et Mme EsteLLon, Rec. p.262

(1)"De telles fins de non-recevoir ne seraient pas seulement contraires aux rapports qui doivent exister entre des juridictions appelées à fournir l'une à l'autre un mutuel appui et non à s'entraver par d'inutiles critiques ; elles constitueraient, en outre, un empiétement sur les pouvoirs du juge du fond : celui-ci est, en effet, le seul juge.. de l'intérêt que présentent les vérifications demandées, au point de vue du jugement du litige".

Laferrière E., Traité de la juridiction administrative, $1^{\text {re }}$ éd., 1887, t. I, p. 452.

(2) CE 28 février 1964, Comm. de Lacanau, Rec. p. 152;- CE 16 juin 2000, Comm. d'Auribeau-sur-Siagne, Rec. p. 232, D 2000, IR, p. 231.

و هو ما يظهر في حالة ما إذا كان العمل المعروض عليه يفتقد للوصف الإداري أي لا يعد عملا إداريا راجع على سبيل المثال بثأن العمل التشريعي: =

مجلتة البحوث القانونيت والإقتصاديت 
سحب العمل المطلوب تقدير مشروعيته، وأيضاً إذا ما تم استئناف حكم الإحالـة وقضي بإلغائه(')، ذلك أن الدعوى في هذه الحالة ستصبح غير ذات موضوع(). وفي مقابل التزام القاضسي الإداري بالإجابـة عن التساؤل المطروح عليه من خلال دعوى فحص المشروعية، فإن ما ينتهي إليه يقيد القاضسي العادي بمعنى أن هذا الأخير لا يملك الحكم في الدعوى المدنية على خلاف ما انتهى إليه القاضي الإداري (")، فهو وإن كـان يستطيع إجبـار القاضسي الإداري على نظر المسألة الأوليسة إلا أن هـا الأخير يظل محتفظكاً بحريته بالنسبة لتقدير المشروعية والتـي يتعين أن يلتزم بها

= CE 15 avril 1970, Jeanson, Rec. p. 252.

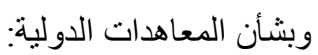

CE Sect. 18 juillet 1951, Soc. Mathieu, Rec. p. 468.

وبثأن عقود القانون الخاص:

CE, 29 octobre 1952, Soc. D'Aubigny-Plage, Rec. p.475;- CE 21 juin 1996, Fischer, RFDA 1996, Rec. p. 859.

(1)CE 13 décembre 1954, Juillet, p. 869 ;- CE 20 novembre 1985, Soc. Automobile marseillaise de ventes, RDP 1986, p. 1180.

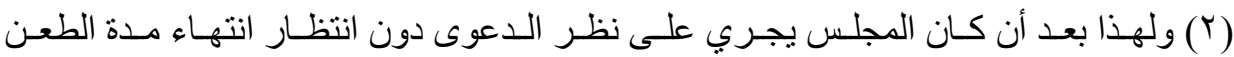

بالاستئناف في حكم الإحالة، وفي حالة الطعن دون انتظار حكم الاستئناف راجع النع على سبيل

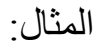

CE 24 février 1989, Bideau, DA 1989, n" 163

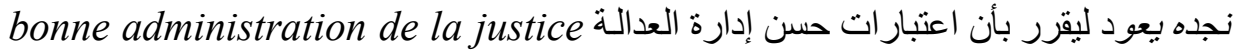
توجب الانتظار لحين انتهاء مدة الطعن، أو صدور الندات حكم في الاستئناف:

CE 27 avril 2007, Comm. de Bailleval, AJDA 2007, p.948, obs. Biget C Chapus R., Droit du contentieux administratif, op.cit, p. 759.

( ${ }^{\top}$ Cass. crim. 4 déc. 1930, Gautrand, D.P. 1931,1. p. 33, note Appleton ; -Cass. civ. 19 juin 1985, Bull. civ.1, n 200; D. 1985, p. 426, note Sargos.

مجلت البحوث القانونيت والإقتصاديت 


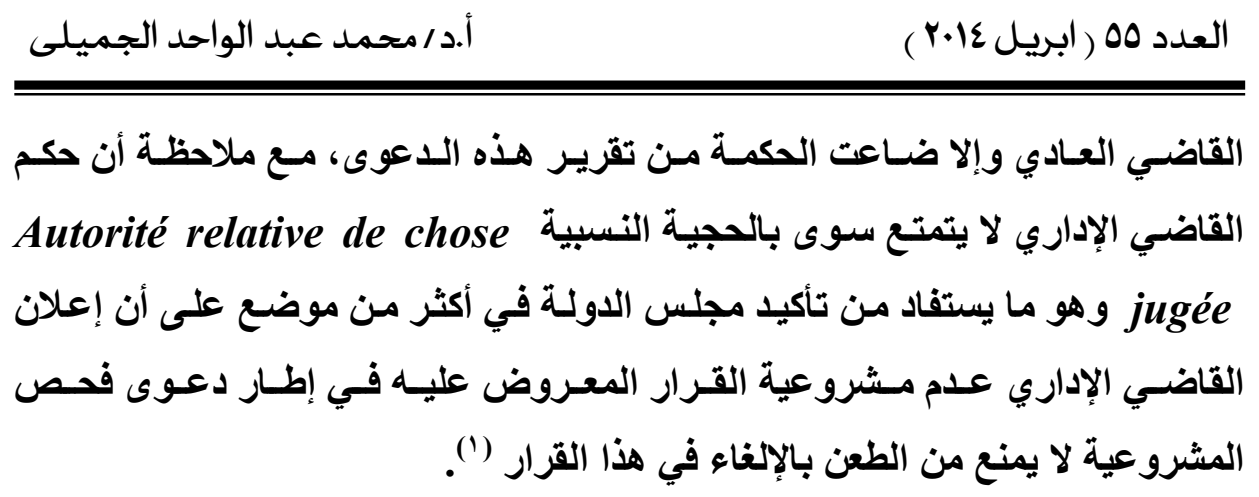

(1)C.E. 6 févr.1981,Dlle Baudet,.p.53;AJDA 1981, p. 489, concl. Dondoux;C.E. 5 juin 1981, Dite Layani, AlDA 1981, p.431.

$$
\text { راجع أيضأ: }
$$

Combeau P., L'activité juridique interne de l'administration, Thèse Bordeaux IV, 2000, p. 526.

$$
\text { لمزيد من التفاصيل بشأن دعوى فحص المشروعية راجع: }
$$

Fliniaux A., Le recours en appréciation de validité, Mélanges Hauriou, Sirey, 1929, p. 297 ; Gabolde C. Recours en appréciation de validité, Répertoire Dalloz de contentieux administratif,( RDCA), t. 3, éd. 1997; Heurté A, Le recours sur-renvoi des tribunaux judiciaires, AJDA 1958, 1, p. 111; Dero-Bugny D., La compétence du juge administratif saisi d'un recours en appréciation de validité d'un acte administratif encadrée par le renvoi préjudiciel du juge judiciaire, RFDA 2006, p. 73. ; Boiteau C. Recours en appréciation de légalité et en interprétation, JCJA, T. 1, Fasc.37 , éd.2002; Seiller B., Questions préjudicielles, RDCA, T. 3 , éd.2000; Gohin O., Exception d'illégalité, RDCA, T. 2, éd. 2005 ; Seiller B, L'exception d'illégalité des actes administratifs, Thèse. Paris 2, 1995; Guettier C., Recours en appreciatjon de validité »,Juris-claauur de droit administratif, fasc.. 1163; Chapus R., Droit $d u$ contentieux administratif, ,op.cit, p. 749. ; Pacteau B., Contentieux administratif, 5 éd. 1999, $n^{\circ} 300$ et s.; I.-M Auby J-M et Drago R., Traité de contentieux administrait!. LGDJ 1984,T.II, p.92 ets..; Traite des recoures en matière administrative, Litec 1992, p. 55 et $s$.

مجلة البحوث القانونيتة والإقتصاديت بT 
ثانيا : التطبيق القضائي لاعوى فحص المشروعية بالنسبة للمنشورات قدمنا أن دعوى فحص المشروعية لا تخضع بشأن قبولهـا سـوى لشرطين:

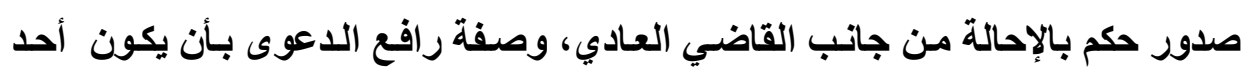

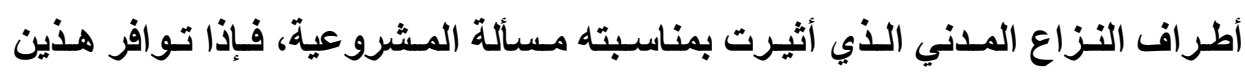
الثرطين فإن القاضي الإداري عليه التصدي لموضوع الدعوى، بغض النظر عن طبيعة

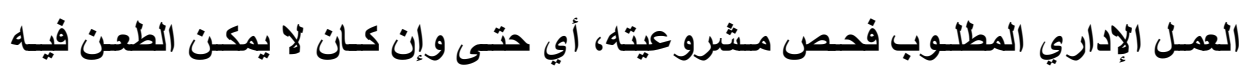
مباشرة بالإلغاء نظرا لتخلف وصف القرار الإداري.

ولا شك أن هذا التوسع بشأن شروط قبول دعوى فحص المشروعية وتغطيتها

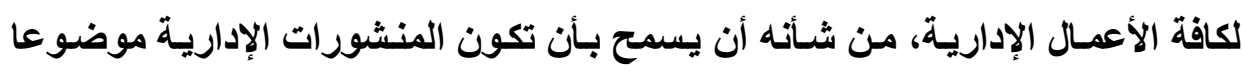
لهذه الدعوى، وذلك إذا مـا عرضت مسألة مشروعيتها أمسام القاضسي المداني بمناسبة نزاع مما يختص بنظره، وقدر بأن الفصل في تلكت المسألة يعد أمراً ضرورياً حتى يمكن حسم النزاع الأصلي.

هذا هو بالتحديد موضوع حكم لوساج Lesage الصادر من مجلس الدولة في

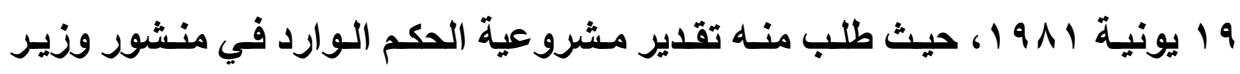

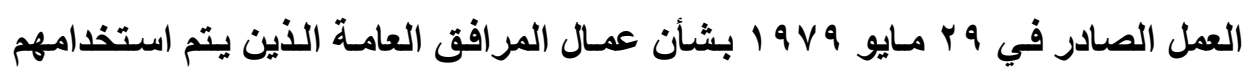
personnels des services publics employés وفقا لشروط القانون الخـاص L.511-1 المنصوص عليهم في المسادة dans les conditions du droit privé من تقنين العمل، والتي نصت صراحة على جعل منازعات العمل المتعلقة بهم من ضمن ، conseils de prud'hommes المنازعات التي تختص بها مجالس منازعات العمل جندين وقد انتهى المجلس في تلك الدعوى إلى أن الحكم الوارد في منشور وزير العمل،

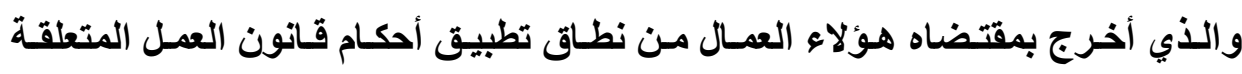


entachée باختصاص هذه المجالس بمنازعات العمل المتعلقة بهم، يعد غير مشروع

\section{(') d'illégalité}

وهو نفس المسلك الذي انتهجه المجلس في قضية "لوم" Lome الصادر في

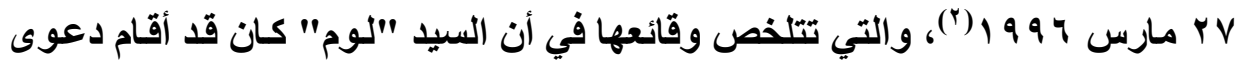

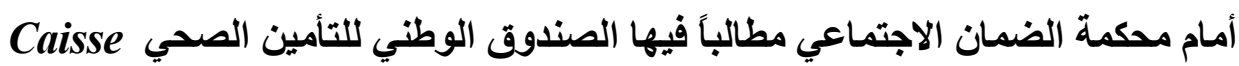
nationale d'assurance maladie التي أجراها في أحد المراكز الطبية، والتي رفض الصندوق تفطيتها أو تحملها استنادا إلى أن خطاب وزير الشئون الاجتماعية الصادر في ب ا يناير 19 ومنشور مدير

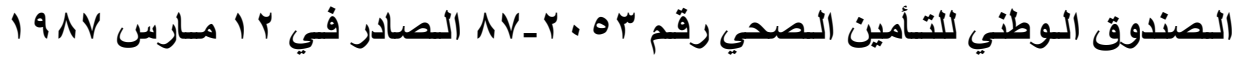
يمنعان تحمل الصندوق مثل هذه النوعية من التحاليل والفحوصـات، وبنـاء على دفع

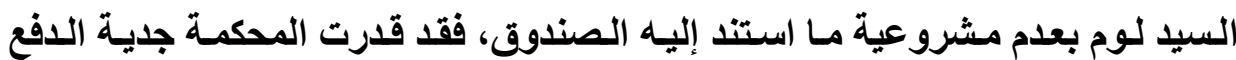
وقامت بوقف الفصل في الدعوى وإحالة مسألة المشروعية للقضاء الإداري للفصل فيها، وعندما عرضت المسألة على مجلس الدولة من خلال دعوى فحص المشروعية كـان حريـصاً على التأكيد بـأن شـروط قبـول هذه الــعوى لا تخضع لنفس الشروط المطلوبة لقبول الطعن بتجاوز السلطة، وبأنه ملزم بالفصل فيها، وفي الموضوع انتهى

(1)"La disposition de la circulaire du ministre du Travail et de la Participation du 29 mai 1979, qui déclare que ces personnels échappent aux dispositions $d u$ code $d u$ travail relatives à la compétence des Conseils de prud'hommes, est entachée d'illégalité".

CE, 19 juin 1981, Lesage, Rec., p. 279 ; D. 1981, IR p. 519, obs. P. Delvolvé $P$.

(2)C.E. 27 mai 1996, Lome, Dr. adm. 1996. n" 287, obs. C.M ; RFDA 1997, p. 1218. note SeillerB.

مجلت البحوث القانونيت والإقتصاديت 
كمـا هو الشأن في حكم "لوسـاج" إلى الحكم بعدم مشروعية خطـاب وزير الشئون الاجتماعيـة ومنشور مدير الصندوق الـوطني للتأمين الصحي لتعارضهما مـع تقنين الضمان الاجتمـاعي code de la sécurité sociale، والذي تعترف نصوصه للمؤمن عليه بالحق في استرداد تلك النوعية من التحاليل طالمـا تم تنفيذها من خلال مختبر معتمد (')

ولا شك أن مـا انتهى إليه المجلس في هذا الأحكام يتقق مـع مـا سبق وأن أشرنا إليهه من أن القاضـي الإداري وإن كان لا يمكنهـه رفض دعوى فحص المشروعية لعدم توافر وصف القرار الإداري في العمل المطعون فيه، إلا أنـه يتمتع بكامل الحريـة بشأن تقدير المشروعية، وبحيث لا يجوز للقاضي المدني كما أسلقنا الخروج على مـا ينتهي إليه في هذا الخصوص. غير أن المشكلة يمكن أن تظهر فيما لو تم الطعن على استقلال بالإلغاء في نفس العمل موضوع دعوى فحص المشروعية، ذلك أن تحريك هذه الأخيرة كما سبق وأشرنا ليس من شـأنه أن يمنـع من الطعن بالإلغـاء لاختلاف شروط قبول كول كل منهمـا، وهو مـا

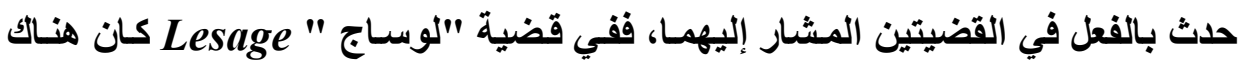
طعن بالإلغـاء ضـد نفس المنشور مقدم من جاتب الاتحـاد الفيدرالي العـام للموظقين Union générale des fédérations de fonctionnaires المجلس أصلدر حكمه في ذلك الطعن في نفس يوم إصداره لحكم "لوسـاج" ، حيث انتهى إلى رفض الطعن في هذا المنشور وذلك تأسيسا على أن " وزير العمل لم يعطي

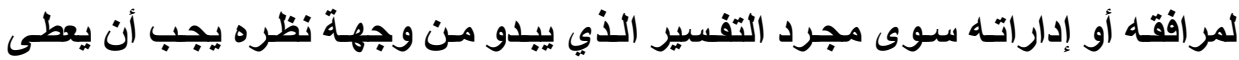
للتشريع الساري، وبالتالي فِإن أحكام المنشور المطعون عليه، لا تتمتع بوصف القرار 
الإداري القابل للطعن بتجاوز السلطة"((')، وفي قضية " لوم " فإن المجلس في حكمين متتاليين كان قد أعلن موقفه بالنسبة لخطاب وزير الثئون الاجتماعية ومنشور مدير الصندوق الوطني للتأمين الصحي حيث رفض في الحكمين قبول الطعن بالإلغاء ضد كل ne présente pas le caractère d'une منهما لعدم تمتعهما بوصف القرار (`) décision

ولا شكك أن المجلس كان يمكنه في دعوى فحص المشروعية تحقيقًا للتناغم أن

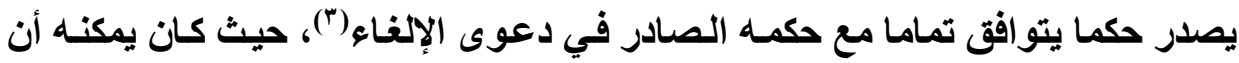

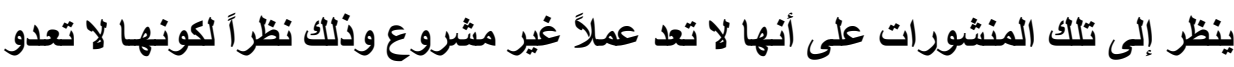

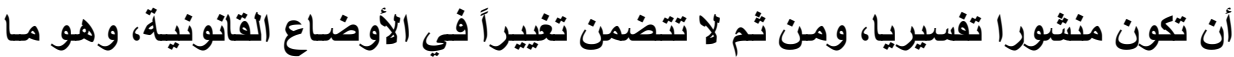
حرص الأستاذ ديلفولفيه Delvolvé على إبرازه في تعليقه على حكم لوساج حيث يقول

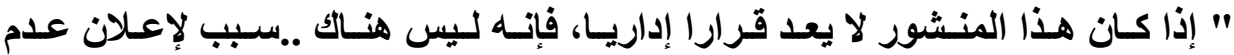

(1)".. s'est borne à donner a ses services l'interprétation qui lui paraissait devoir être donnée de la législation en vigueur, que par suite ces dispositions ne présentent pas le caractère d'une décision administrative susceptible d'être déférée au juge de l'excès de pouvoir"

CE 19 juin 1981, Union gén. des fédérat. de fonctionnaires, Rec. p.273, D 1981, IR, p. 519, obs. Delvolvé P.

$$
\text { (r) (r) (بالنسبة لخطاب وزير الثئون الاجتماعية راجع: }
$$

CE, 24 avr. 1992, Centre européen d'information et d'automation, req. $n^{\circ}$ 92-280.

http:/legimobile.fr/fr/jp/a/ce/ad/1992/4/24/92280/

$$
\text { وبالنسبة لمنشور مدير الصندوق الوطني للتأمين الصحي راجع: }
$$

CE, 23 juin 1993, Laboratoire d'analyses médicales Burckel, req. n 131-679.

(3)Seiller B. Circulaires et légalité, note sous Conseil d'Etat, 27 mars op.cit, p. 1220. 
مشروعيته، حيث يكفي القول بأنه لم يضيف للأحكام التشريعية واللائحية النافذة، ولم يعدل الأوضـاع القانونيـة، ومـن ثم لا يمكن أن يكون غير مشروع، وهذا مـن شـأنها التوفيق بين الطبيعة غير اللائحية للمنثور وضرورة الإجابة عن المسألة الأولية "(').

غير أن المجلس في حكم "لوسـاج" وحكم " لوم " اتبع مخرجـاً آخر يبدو فيها

قرر من التناقض أو التعارض، حيث اعتبر المنشور غير اللانحي غير مشروع، وهو ما استنكره بشدة الاستاذ ديلفولفيه Delvolvé في تعليقه على حكم "لوسـاج" السابق

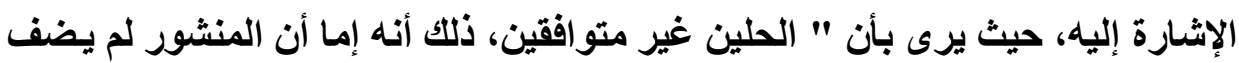
جدياً ومن ثم يعد تفسيري ولا يمكن بالتـالي الحكم بعدم مشروعيته، وإمـا أنـه يخالف حكم قائم، في هذه الحالة سيعد لائحي وغير مشروع إذا كان لا يـخل في اختصاص

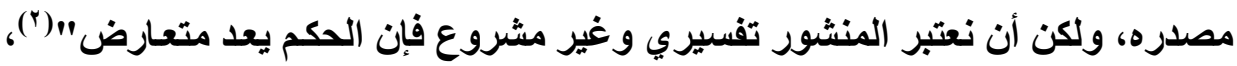

(1)" Si cette circulaire ne constituait pas une décision administrative, il n'y avait pas (...) matière à en déclarer l'illégalité. Il suffisait de dire que n'ayant pas voulu ajouter ou retrancher une disposition aux textes législatifs et réglementaires en vigueur, ne modifiant pas l'ordonnancement juridique, elle ne pouvait être illégale (...) : c'ê̂t été concilier à la fois le caractère non réglementaire de la circulaire et la nécessité de répondre à la question préjudicielle."

Delvolvé P., obs.sur CE 19 juin 1981, Union gén. des fédérat. de fonctionnaires, D 1981, IR, p. 519, op.cit.

(2)" Les deux solutions sont incompatibles : ou une circulaire, n'ajoutant rien à l'état du droit, est seulement interprétative et, faute, par là même, de méconnaître une norme juridique, elle ne peut être déclarée illégale; ou bien, contredisant une solution antérieure, elle est réglementaire, et illégale si la mesure qu'elle édicté échappait au pouvoir de son auteur. En reconnaissant que la circulaire est à la fois interprétative et illégale, l'arrêt se contredit".

Delvolvé P., obs. , op.cit.

مجلت البحوث القانونيت والإقتصاديت 1 
وييدو أن الأستاذ سييير Seiller في تعليقه على حكم " لوم " انضم لهذا الرأي حيث

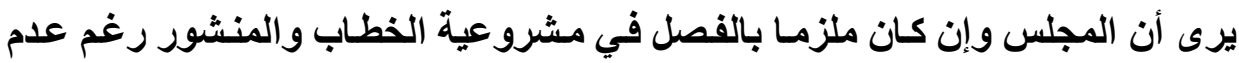

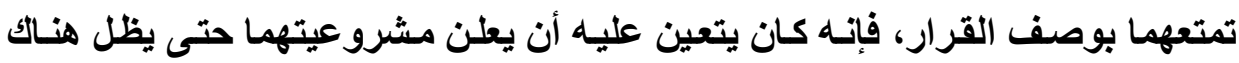

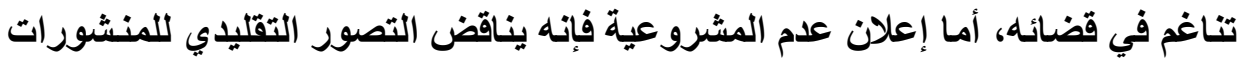
(1)، والذي يميز بشأن المشروعية بين المنشورات التفسيرية والمنشورات اللانحية، فالمجلس كان يمكنه وفقاً للأستاذ سيير Seiller إصدار حكماً يتو افق تماماً مع أحكامـه

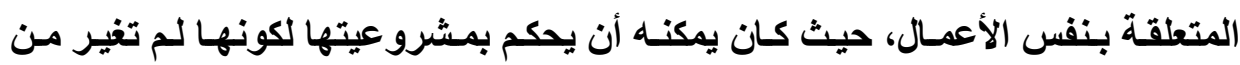
الأوضـاع القانونية)(")، وقد عارض الاستاذ كومبو Combeau مـا ذهب إليه الأستاذ "ديلفولفيه" Delvolvé حيث يرى - بحق - بأن عدم التوافق الذي أثـار إليه الأستاذ

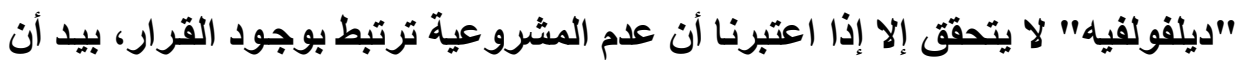

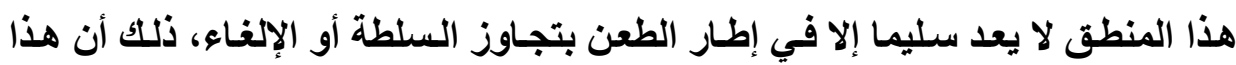
الطعن وما ينجم عنه من إبطال في حالة عدم المشروعية لا يمكن أن يتحقق إلا إذا كان الطان

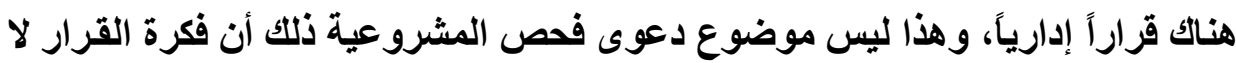

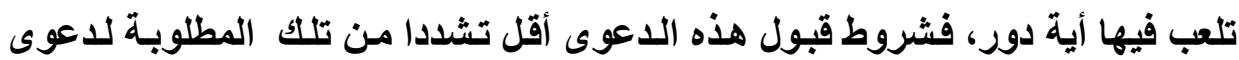
الإلغاء، ومن ثم فإنه يعد نوعاً من الخلط بين دعوى فحص المشروعية ودعوى تجاوز

(1)" Tenu de statuer sur la légalité d'une lettre et d'une circulaire non décisoire, il aurait dû déclarer leur légalité pour rester cohérent. En déclarant leur illégalité, il remet en cause la conception traditionnelle des circulaires"

Seiller B., Circulaires et légalité, note sous Conseil d'Etat, 27 mars 1996, M. Lome, op.cit, p. 1220.

(2)Seiller B., Ibid. 
السلطة قبول فكرة أن عدم المشروعية لا يمكن أن تلحق سوى القرارات الإدارية ('). وفي جميع الأحوال فإن إعلان المجلس في حكم "لوسـاج" وحكم "لوم" عدم مشروعية المنشور رغم إعلانه في أحكام سابقه عدم قبول الطعن ضده بالإلغاء ــ لعدم إمكان إضفاء الطابع اللائحي عليه، نظرا لكونه لا يضيف جديداً تطبيقا للمعيار المستمد

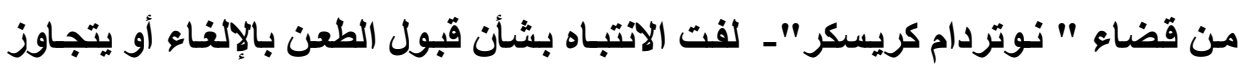
السلطة ضد المنشورات إلى ضعف الأسـاس أو المعيـار الذي اعتمـد عليه المجلس في التمييز بين المنشورات ذات الطبيعة اللائحية وتلكك ذات الطابع التفسيري، ذلك أن هناك أعمالاً لم يتردد المجلس في قبول الطعن بالإلغاء ضدها رغم أن الفرض فيها أنها لا

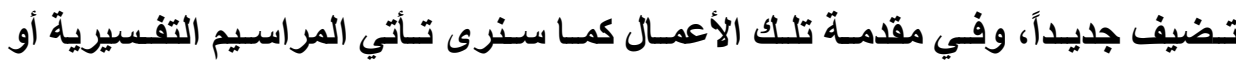
التطبيقية.

(1)Combeau P., L'activité juridique interne de l'administration. Contribution à l'étude de l'ordre administratif intérieur, Thèse, op.cit, p. 527.

$$
\text { V . مجلة البحوث القانونيت والإقتصاديت }
$$




\section{المبحث الثاني}

\section{فشل الماولات التشريعية واللائحية في فرنسا \\ الراهية إلى تعميم الاحتجاج بالمنشورات}

سبق وأن أشرنا إلى أن النظام القضائي للمنشورات بدءا على الأقل من عام

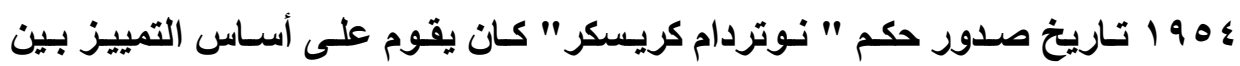
المنثورات اللائحية والمنشورات التفسيرية، حيث تم النظر إلى الأولى على أنها تعد

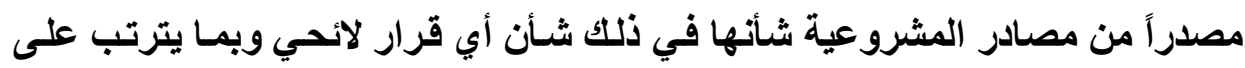

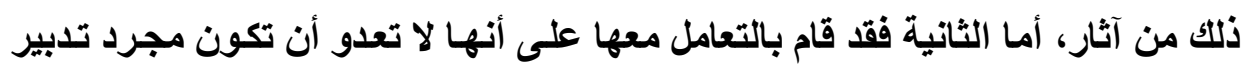

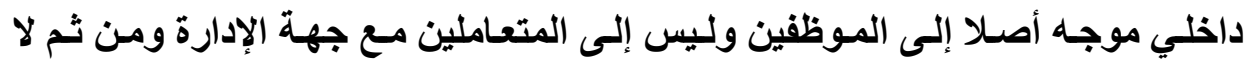

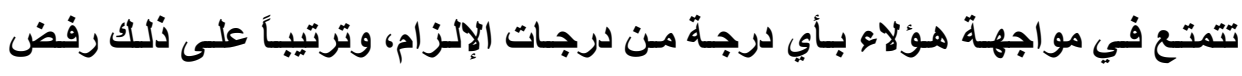

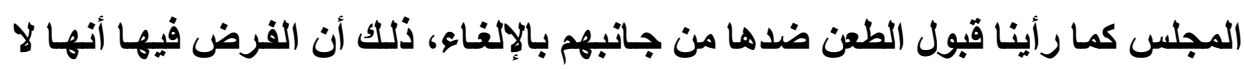

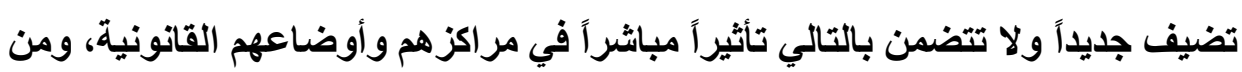

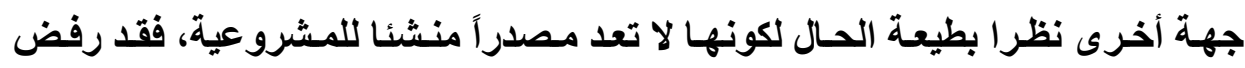
الاحتجاج بها في مواجهة جهة الإدارة، فلهذه الأخيرة مخالفتها فيما تصدره من قرارات

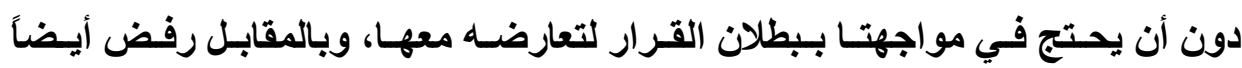
الاحتجاج بها في مواجهة المتعاملين مع جهة الإدارة، بمعنى أنه لا يجوز الاستناد إليها لفرض قيود والتزامسات أو منح حقوق غير منصوص عليها في اللانحة أو القانون

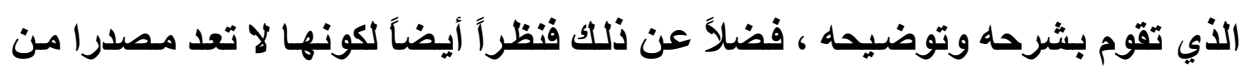

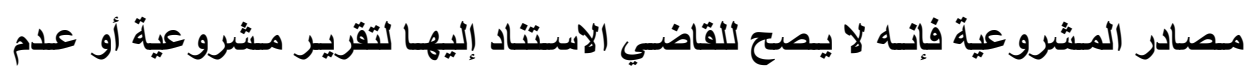

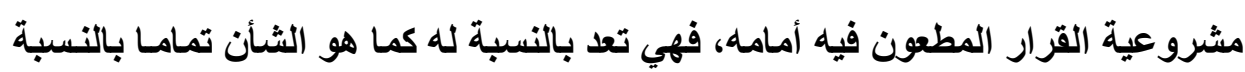

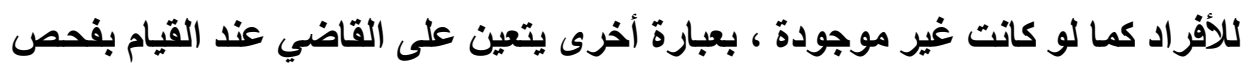

VI مجلتً البحوث القانونيت والإقتصاديت 
مشروعية القرار المطعون فيه النظر فقط إلى الأحكام الواردة مباشرة في القانسون أو اللائحة دون التفات إلى ما ورد النص عليه في المنثور التفسيري.

فالعقبـة الرئيسة أمسام القاضسي الإداري بـشأن الاعتـراف بإمكاتيـة الاحتجـاج

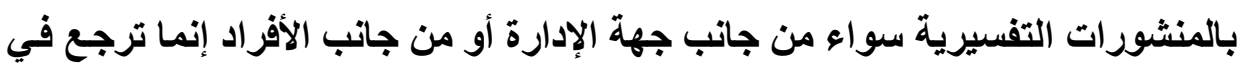
الأساس إلى أنها وإن كانت تتمتع بصفة العمومية والتجريد، إلا أنها لا تعتبر بمثابة التهابة

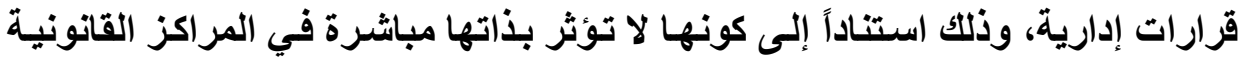

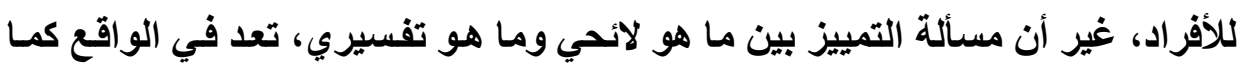
سبق وأثرنا مسألة صعبة وشـائكة وتحتاج إلى بحث دقيق، تضاربت بشأنها أحكام القضاء.

ولنا أن نتساءل كيف يمكن إقناع المتعاملين مع جهة الإدارة بأن مخالفة هذه الأخيرة للمنشور الصادر عنها وتمتعه في نفس الوقت بالحصانة القضائية إنما ينبع بكل بساطة من كونه لا يعدو أن يكون منشورا تفسيرياً، ومن ثم فإن لها أن لا تتقيديد بـانه

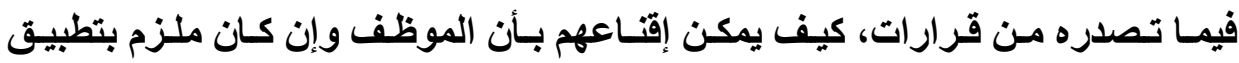
المنشور التفسيري انطلاقا من واجب الطاعة المفروض عليه حيال رؤسائه، إلا أنه لا لا

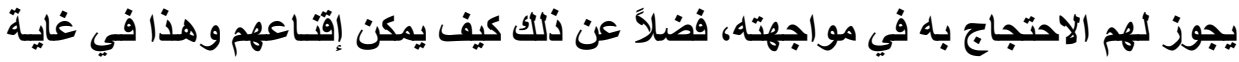
الأهمية بأن النظام القضائي للمنشورات التفسيرية يختلف عن ذلك المطبق بالنسبة للتوجيهات Les directives، فهذه الأخيرة كما هو الشأن بالنسبة للمنشورات والتي قد تختلط بها كثيراً في العمل(')، تصدر أيضاً من رؤسـاء المصالح إلى المرؤوسين،

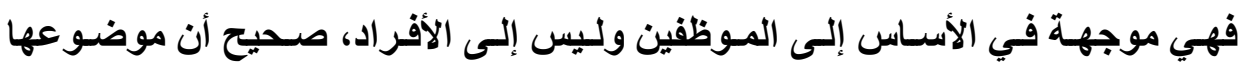


يختلف عن المنشورات، ذلك أنه إذا كان الغرض من هذه الأخيرة يتمثل أساسـا في تفسير وتوضيح القوانين واللوائح القائمة وبيان كيفية تنفيذها، فإن التوجيهات تظهر في الحالات التي يترك فيها المشرع لجهة الإدارة حريـة تقدير وجـه التصرف، أي في الحسالات التـي تتمتع فيها جهـة الإدارة بسلطة تقديريـة بشأن تحديــ مضمون القرار الإداري الـصادر عنهـا، حيـث يقـوم الـرئيس الإداري الأعلـى مقـدما، تحقيقـا لتـــاغم cohérence المتعمد بين المتعاملين مـع جهة الإدارة، بتحديد المعايير الموضوعية أو خط السير Ligne de conduite اتخـاذ القرارات الفرديـة المتعلقة بمجـال معين(')، ولا شك أن مثل هذا الهدف هو مـا تسعى إليـه المنشورات، ومـع ذلكـ رغم رفض المجلس إضـفاء وصف القرار على التوجيهات شأنها في ذلك شأن المنشورات التفسيرية مما يعني عدم جواز الطعن فيها مباشـرة بالإلغـاء، اسـتناداً إلسى كونهـا لا تـؤثر بـذاتها مباشـرة في المراكز القانونيـة

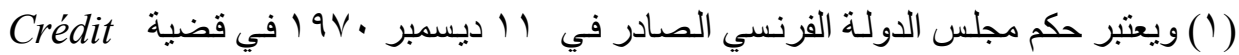
foncier de France

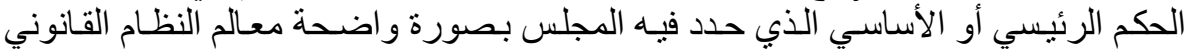
للتوجيهات، وأوجه الاختلاف بينها وبين اللو ائح والمنشورات التفسيرية:

CE, 11 déc.1970, Crédit foncier de France, Rec..p.750, Concl. Bertrand P., AJDA 1971,p.196, chr.H T.C.;D.1971, p.673, note Loschak D., JCP 1972, n'17232, note Fromont M; RDP1971, p.1224,note Waline M; Long M. et autres,op.cit, p. 637.

وقد تبع هذا الحكم أحكامـا أخرى اكنملت بها ملامسح فكرة التوجيهات، بحيث أصبحت تشكل نظرية تخضع لنظام قانوني مستقل ومن أبرز هذه الأحكام: CE Sec.29 juin1973,Soc.Gea,Rec.p.453,AJDA1973,p.587.chron.Franc M.et Boyon,et p.590 note C-L vier ,D. 1974 p.141, note Durupty M., RDP 1974, note Waline M.;- CE 18 nov. 1977, sté Marchand, AJDA !978, P. 676. 
للأفراد(')، إلا أنه سمح في نفس الوقت للمتعاملين مـع جهة الإدارة بإمكانية الاحتجـاج بما ورد فيها من قيود وأحكام يشأن ممارسة السلطة التقديرية، أي بالدق في الاستناد إليها كمبرر لطلب إلغاء القرار الصادر بالمخالفة لها، كما اعترف أيضاً من حيث المبدأ، بمشروعية قيام جهة الإدارة بالاستناد إليها صراحة لتبريز القرار الصادر عنها، ممـا يعني اعترافه لها بالحجية سواء في مواجهة الإدارة أو في مواجهة المتعاملين معها (r، بل أمام القاضي الإداري نفسه عندما يطرح أمامه نزاع حول القرار المستثد إليها"َ).

$$
\text { (1) و هو ما أكده المجلس صر احة في حكمه : }
$$

CE 18 oct.1991,Union nat. de la propriété immob. ,Rec.p. 338, DA1991, $n^{\circ} 487$.

(Y) وقد كان من المفترض نظر آلتقبد جهة الإدارة والأفر اد بالتوجيهات، على التفصيل السابق،

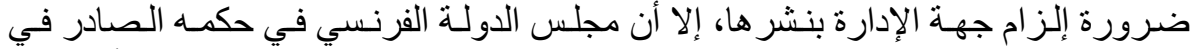

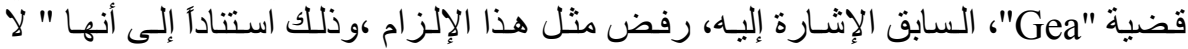

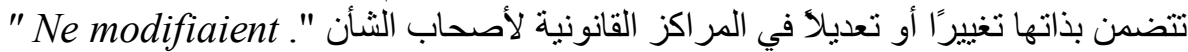
"

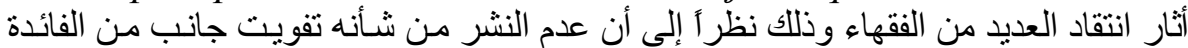

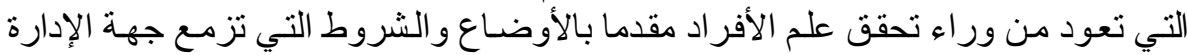

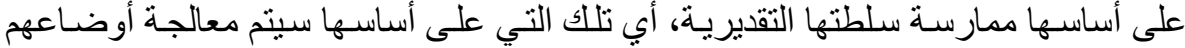

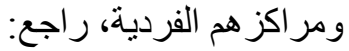

Long M. et autres, les grands arrêts de la Jurisprudence administrative, 10e édition, Sirey, 1993., op.cit, P.645.

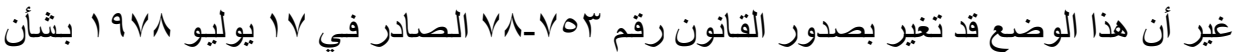

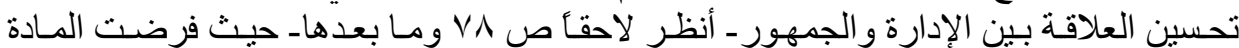

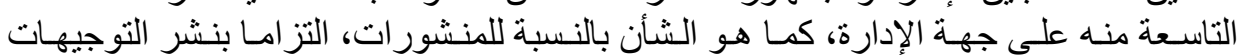

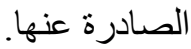

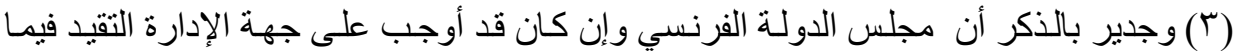

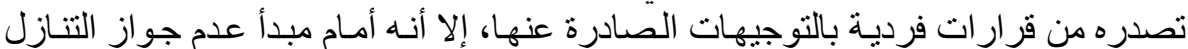

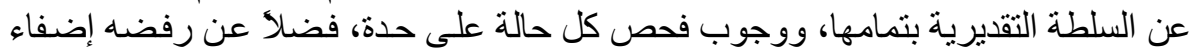

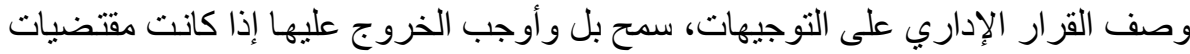

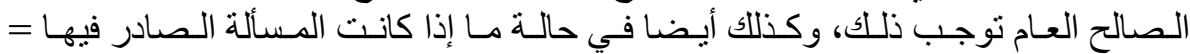




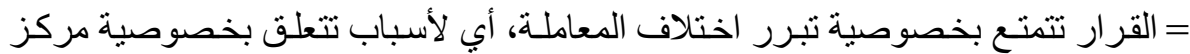

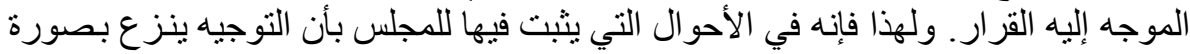

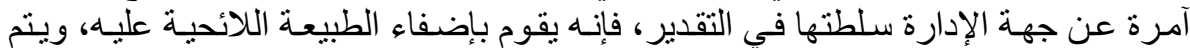
التعامل معه وفقا لهذا الأساس مما يعني جو از الطعن عليه مباشرة بالإلغاء. راجع على سلى سبيل

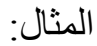

CE, 23 septembre 1983,Assoc. Information-Defence-Action-Retraite, Rec.p. 369, RDSS 1984, p. 525, concl. Genevois B.

Chapus R., Droit du contentieux administratif, op.cit, p. 548.

$$
\text { لمزيد من التفاصيل يشأن التوجيهات في الفقه الفرنسي راجع: }
$$

De Laubadère,Traité de droit administrative, Op.cit, p.519;Chapus R., Droit administratif, op.cit,p.461.; - Droit du contentieux administratif, Montchrestien, 13 ed., 2008, p. 547 .;Delvolvé P., La notion de directive, AJDA 1974, p. 459; Chevallier F., Contribution à l'etude des actes directifs, these, Paris, 1975;Boulouis J.,Sur une categorie nouvelle d'actes juridiques: les "directive, Mél. Eisenmman, éd. Cujas, 1975 , p.191.

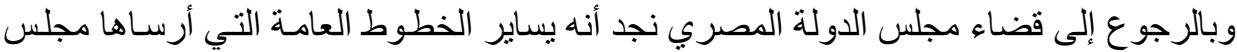

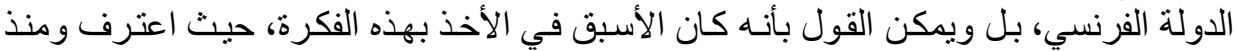

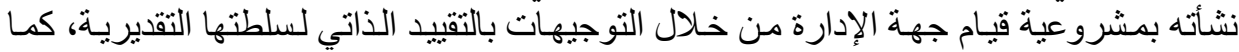

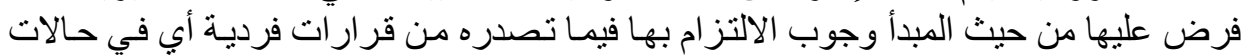

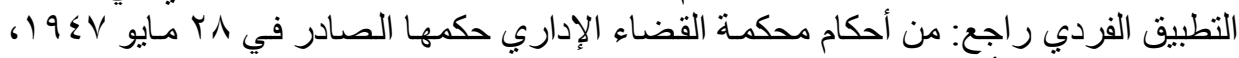

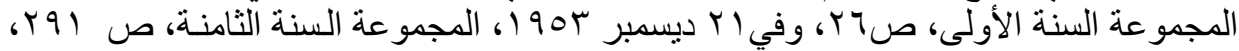

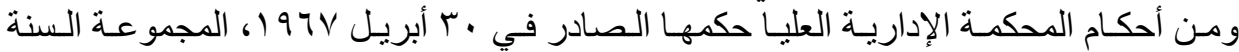

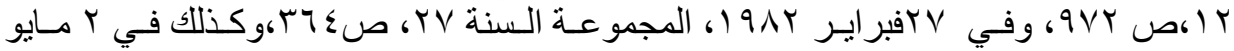

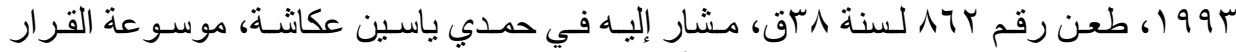

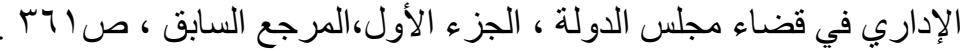

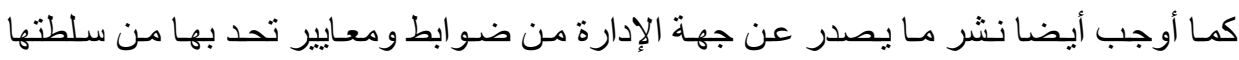

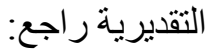

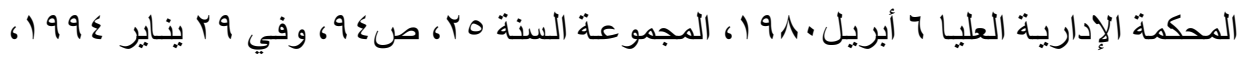

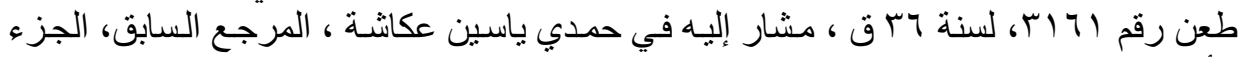
الأول، صن صن 
ولهذا حساول المشرع التنظيـي الفرنسي- ونقصد بـذلك السلطة اللائحيـة ـ

معالجة مثل هذا التناقض من خلال السماح من حيث المبدأ للمتعاملين مع جهة الإدارة

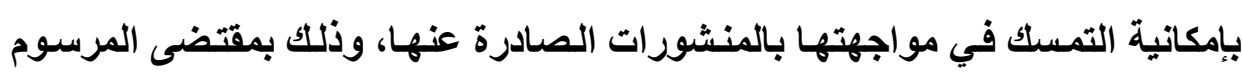
Décret

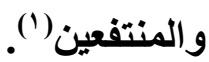

وينـاء عليـه سـنعرض أولا للمبدأ الـذي تـم تكريسه بمقتضى هـذا المرسـوم "المطلب الأول" ثم نعقبه ببيان موقف الفقه " المطلب الثاني "وأخيراً موقف القضاء

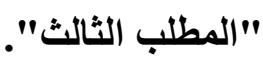

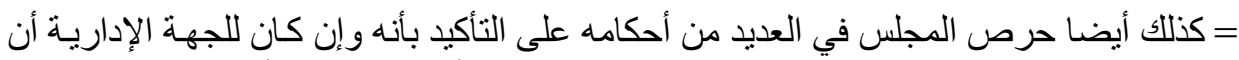

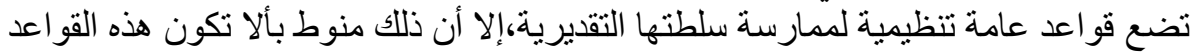

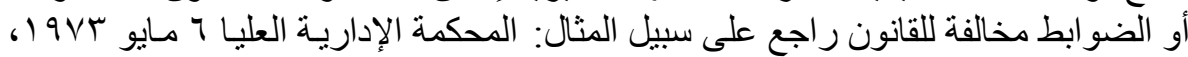

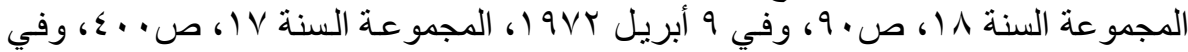

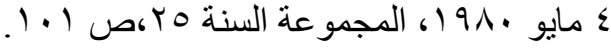

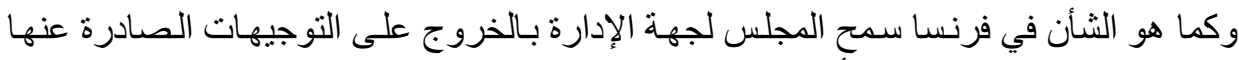

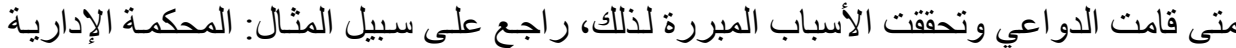

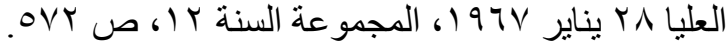

(1) Décret n'83-1025 du 28 novembre 1983 Concernant les relations entre l'administration et les usagers, Journal Officiel du 3 déc.1983,p.3493 . 


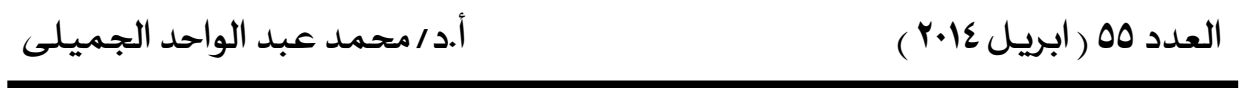

\section{المطلب الأول}

\section{تكريس المشرع التنظيسي الفرنسي لمبدأ الاحتجاج}

\section{بالمنشورات الإدارية في هواجهة الإدارة}

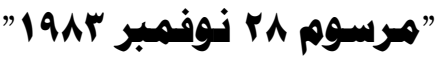

دون الاخول في تفاصيل هذا المرسوم والذي أنى في إطار موجة من الإصـلاحات

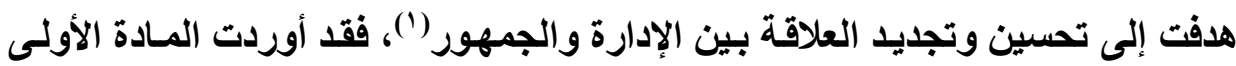

منه حكمـاً يمكن النظر إليه على أنسه يؤدي إلى قلب الأوضـاع المستقر عليها قضائياً

بالنسبة للمنشورات، حيث جاء نصها على النحو التالي" يحق لكل ذي مصلحة التمسك

في مواجهة الإدارة بالتعليمات instructions والتوجيهات directives والمنشورات

circulaires

$$
\text { (1) (1) (1) بثأن هذا المرسوم راجع: }
$$

Maisi H., Wiener C., WoehrlingJ-M., "Un décret ne fait pas le printemps ", AJDA 1984, p. 142; . Combeau P., Un oubli dans la réforme : l'invocabilité des et instructions administratives, AJDA 2000, p. 495.; Auby J.-M, , Le décret du 28 nov. 1983,. AJDA 1984, p. 124 et s. ; Baraduc-Benabent E. et Pannentier L., Sauf urgence ... sous réserve ... et exception faite ou le décret du 28 novembre 1983, D. 1984, p. 93 et s. ; Delvolvé P., De nouvelles modalités pour les actes administratifs unilatéraux, D. 1984, p. 137 et s. ; Robineau Y. ,Le décret du 28 novembre 1983 concernant les relations entre l'administration et les uugers, in Adaùnistraticn: droits et attentes des citoyens, Colloque I.F.S.A. déc 1997, La doc. franç. 1998, p. 83 et s.. Drouot G., Le décret du 28 nov. 1983, AEAP 1984, p. 461 et s. ; LepageJessca C., Le décret dn28 nov. 1983 concernant les relations entre l'administration et les usagers : une mini-révolution?, Gaz. Pal. 1984, doctr., p. 145 et s. ; Amselek P., L'opposition à l'administration de sa propre doctrine, les innovations apportées par le décret $d u 28$ nov. $=$

VPV مجلت البحوث القانونيت والإقتصاديت 
المنصوص عليها في المادة التاسعة من قانون V ليوليو 9 V (')، شريطة ألا

تكون مخالفة للقوانين واللوائح " (؟).

ويتمثل الموضوع الأساسي لقانون V V يوليو 19 V المشار إليه في هذه المادة

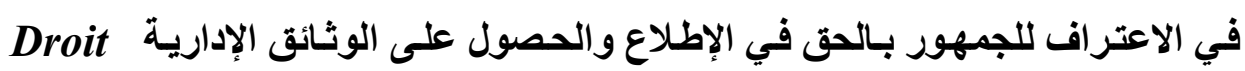
d'accès aux documents administratifs الحركة الإصلاحية التي اجتاحت فرنسا في الثمانيات تحقيقًا للشفافية الإداريـة، ونظراً

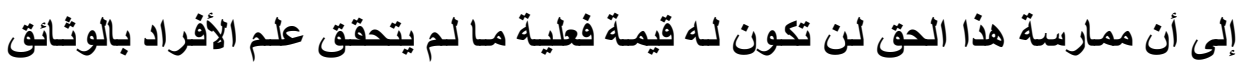
الإدارية الصادرة عن الجهات الإدارية، لذا فقد فرضت المسادة التاسعة مـن هذا القـانون publication régulière على جهة الإدارة التزاماً بوجوب النشر المنتظم أوالدوري

$=1983$ Rev. droit fisc. 1984, $n^{\circ}$ 4, p. 19 et s. ; Heinis M., L'art. ler du décret du 28 nov. 1983 devant le juge de l'impôt », LPA ler juill. 1994, $n^{o} 78$, p. 7 et s. ; Noël G., Les vicissitudes des circulaires opposables, RJCO 1989, p. 17 et s.

$$
\text { (1) المتعلق بتحسين العلاقة بين الإدارة و الجمهور VA_vor رق }
$$

Loi $n^{\circ}$ 78-753 du 17 juillet 1978 portant diverses mesures d'amélioration des relations entre l'administration et le public, Journal Officiel du 18 juillet 1978, p.2851

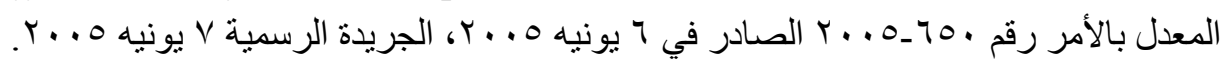

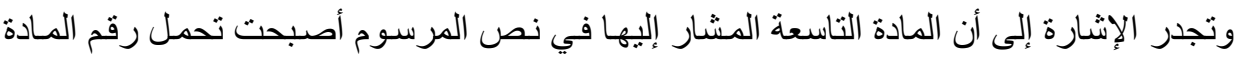

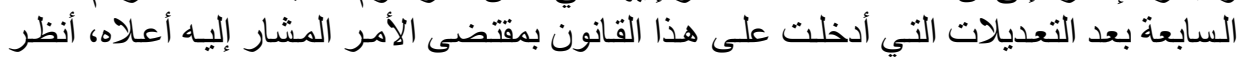

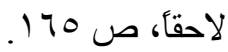

(2)"Tout intéressé est fondé à se prévaloir, à l'encontre de l'administration, des instructions, directives et circulaires publiées dans les conditions prévues par l'article 9 de la loi susvisée du 17 juillet 1978, lorsqu'elles ne sont pas contraires aux lois et règlements". 
لما يصدر عنها من وثائق إداريـة قابلة للإطلاع عليها(')، وأحالت إلى مرسوم يصدر بشأن تحديد الكيفيـة التي سيتم بها النشر والإعلان بعد أخذ رأي لجنة الإطلاع على commission d'accès aux documents administratifs الوثائق الإدارية وإقرار مجلس الدولة décret en Conseil d'Etat (CADA)

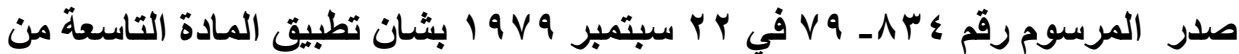

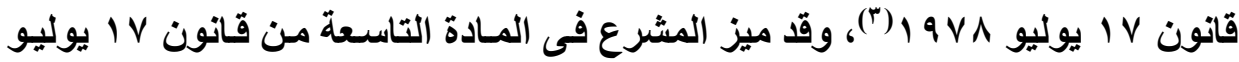

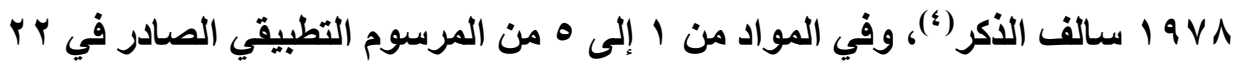
سبتمبر 9 \ 9 بين طائفتين من الوثائق: الأولى: وتشمل التوجيهات Directives Instructions التعنيمـات Circulaires التعليقـات والإجابـات الوزاريـة Notes et réponses ministérielles

( ) ذللك أن هنالك بعض الوثائق أخرجها المشر عن من إطسار مباشرة هذا الحق، من ذللك الوثائق

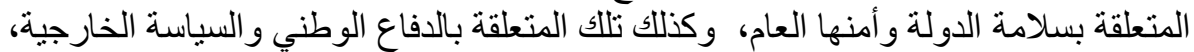

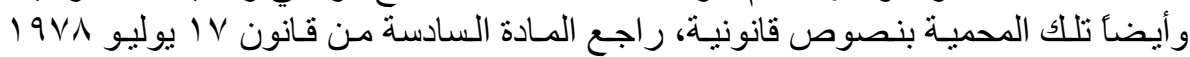

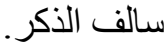
(r) ويجري نص المادة التاسعة باللغة الفرنسية قبل تعديلها عام ه . . ع على النحو الآتي:

" Font l'objet d'une publication régulière : 1-Les directives, instructions, circulaires, notes et réponses ministérielles qui comportent une interprétation $d u$ droit positif ou une description des procédures administratives ; 2- La signalisation des documents administratifs. Un décret en Conseil d'Etat pris après avis de la commission d'accès aux documents administratifs précisera les modalités d'application du présent article".

(3) Journal Officiel du 29 sept. 1979, p.2418.

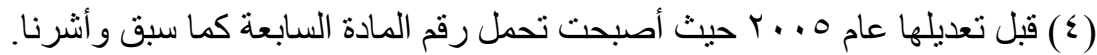

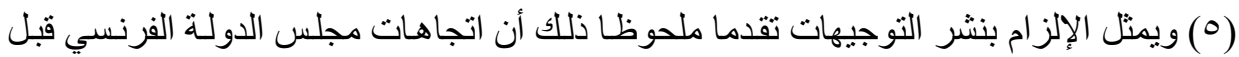
صدور هذا القانون كما ر أينا لم تكن تلزم جهة الإدارة بنشر ها. 
وصفاً للإجراعات الإدارية، حيث استوجب بالنسبة لهذه الطائفة نشرها كاملة سواء فى نشرات رسمية Bulletins officiels عامـة أو محلية أو نسخها وتدوينها فى سجل مفتوح للعامـة، أمسا الطائفة الثانيـة: فتشمل ماعدا ذلك من وثنائق كالمحاضر والآراء والتقارير حيث اكتفى بالنسبة لها مجرد نشر إشارات Signalisation عنها كعنوانها، وموضوعها وتاريخها والمكان الذى يمكن الإطلاع عليها فيه('). غير أن المشرع في قانون V V I V 1 و وإن كان قد فرض النشر على النحو السالف بيانه، إلا أنه لم يحدد أثر النشر بالنسبة لسريان تلك الوثائق في مواجهة

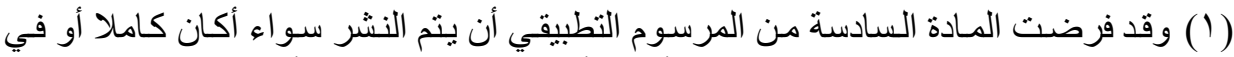
صورة إشار ات خلال الأربعة أشهر التالية لصدور الأعمال المشار إليها.

"La publication et la signalisation prévues aux articles premier à 5 cidessus doivent intervenir dans les quatre mois suivant la date du document concerné."

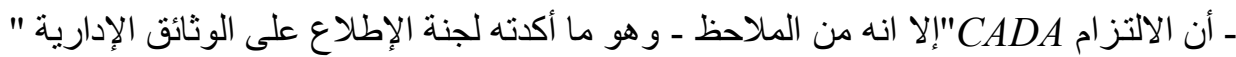

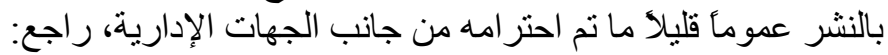

Lasserre B., six ans après le vote de la loi du 17 juillet 1978, une administration plus transparente? EDCE 1983 - 1984 P. 103; CADA, 4 ème rapport, $P .11$

لمزيد من التفاصيل بشأن قانون VI يوليو 9 ا ا و المرسوم الصادر بشأن تطبيق المـادة التاسعة

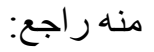

Dibout P., La liberté d'accès aux documents administratifs, Rev. adm. 1979, p. 23 et s. ; Even B., La notion de document administratif., AJDA 1985, p. 528 et s. ; Lasserre B., Six ans après le vote de la loi du 17 juillet 1978, une administration plus transparente?,EDCE 1983/1984, p. 99 et s, ; Braibant G., Droit d'accès et droit à l'information, Mélanges Charlier, 1981, P. 704; Delaunay B. $L$ 'amélioration des rapport entre l'administration et les administrés, LGDJ , 1993. 
المتعاملين مع جهة الإدارة'(')، كما أنه لم ينص على أي جزاء يمكن تطبقه في حالة عدم احترام هذا الالتزام، ولهذا استقر الرأي إجابة عن هذا التساؤل على أن النشر ليس من النّاء

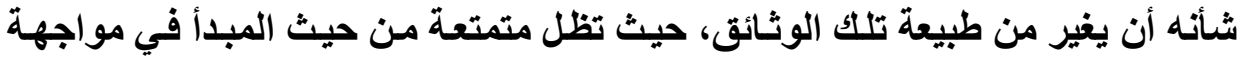
الأفراد والإدارة بنفس الطبيعة التي كانت تتمتع بها قبل النثر (†)، وسنعود لهذه النقطة مرة أخرى لتحديد ما إذا كانت تلكك الوجهة يمكن أن تتغير عند تحليل الحكم الوارد في

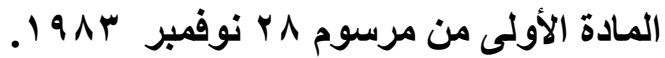

وجدير بالذكر أن مرسـوم به19 جـاء في أعقـاب مشروع قـانون كسان أكثر طموحاً un succédané d'un projet plus ambitieux في تحقيق الحمايـة

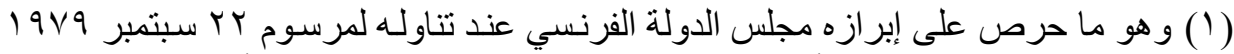

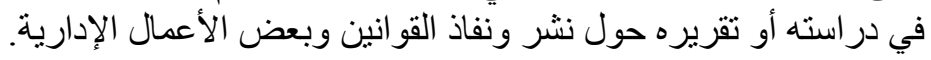
"mettent en ouvre le principe de la liberté d'accès aux documents administratifs et précisent les modalités selon lesquelles certains textes doivent être mis à la disposition des administrés. Elles ne traitent pas directement des effets de la publication sur l'entrée en vigueur des actes".

Conseil d'Etat, Publication et entrée en vigueur des lois et de certains actes administratifs, La Documentation française, coll. Etudes du Conseil d'Etat, 2001, p. 20.

Long M. et autres, Les grands arrêts de la jurisprudence administrative, 10e édition, Sirey, 1993,op.cit, p. 297; Bemba J., L'activité administrative non contrôlée par le juge, thèse, Rennes I, 1991, p.196.

ومن أحكام المجلس راجع: CE, 18 oct. 1991, Union nat. de la propriété immob.,Rec. 
للمتعاملين مع جهة الإدارة إلا أنه لم يكتب له النجاح(')، وهو المشروع الذي كانت قـ تقدمت به الحكومة في عام 1919 1، واتجهت فيه إلى توحيد التسمية بالنسبة للتعليمـات

والمنـشورات والتوجيهـات، بحيـث يطلـق عليهــا جميعـاً التوجيهــات Directives وإخضاعها لنظام قانوني موحد يسمح بإمكانية الاحتجـاج أو التمسك بها دون تمييز بالنسبة للمنشورات بين ما إذا كاتت تفسيرية أو لايحية(؟) ورجوعاً إلى نص المادة الأولى من مرسوم به19 السابق الإشارة إليها، نجد

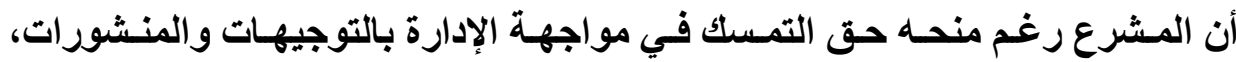
وعدم التفريق بالنسبة لهذه الأخيرة بين المنشورات اللائحية والمنشورات التفسيرية، إلا أنه مـن المفترض أن فائدة النص بالنسبة للمنشورات يجب ألا تظهر إلا بالنسبة

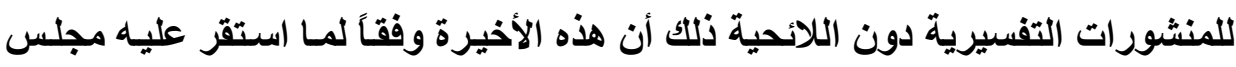
الدولة ـكما رأينا ـ تأخذ حكم القرارات اللائحيـة، ومن ثم يمكن التمسك بها سواء في مواجهة الإدارة أو في مواجهة الأفراد، بعبارة أخرى تتقيد بها الإدارة كمـا يتقيد بها

(1)Delaunay B. L'amélioration des rapport entre l'administration et les administrés, LGDJ , 1993,p. 282.

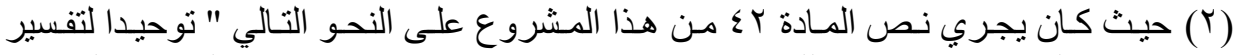

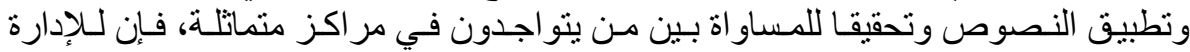

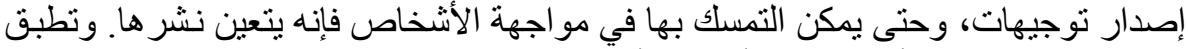

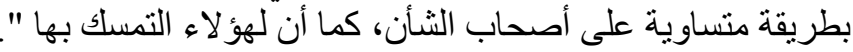

" en vue d'unifier l'interprétation et l'application des textes et d'assurer l'égalité de traitement des personnes se trouvant dans une situation identique, l'administration peut édicter des directives. Pour être opposables, ces directives doivent être publiées. Elles sont applicables de manière égale à tous les intéressés et peuvent être invoquées par eux."

Noël G., Les vicissitudes des circulaires opposables, op.cit, p. 31.

مجلمت البحوث القانونيت والإقتصاديت 
الأفر اد، وبالنسبة للتوجيهات فإن المشرع وإن كـان لـم يضف جديداً للنظام القضائي الذي يحكمها وذلك بالنسبة للاحتجاج بما ورد فيها من قيود وأحكام في مواجهة الإدارة وفي مواجهة المتعاملين معها ، إلا أن صياغة نص المادة الأولى توحي بأنه لم يعد في مقـدور الإدارة كمـا هـو مقـرر في النظــام القضائي الخـروج عليهـا سـواء اسـتجابة لاعتبارات الصالح العام أو لخصوصية مركز الموجه إليه القرار (')، وذلتك استتاداً إلى

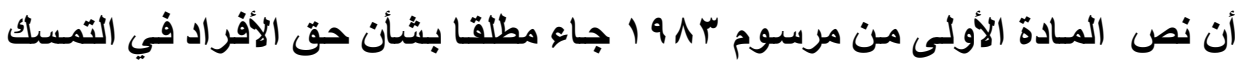

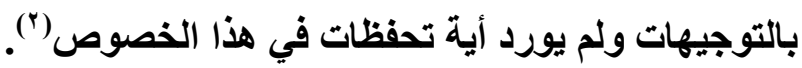

ومـن الملفت أن نـص المرسـوم لـم يمنـح حق الاحتجـاج بالمنشور أو التوجيه سوى للأفراد في مواجهة الإدارة، مما يعني أنها من المفترض بمجرد نشر منشور أو توجيهه فـإن جهة الإدارة ستصبح مقيدة بمـا نشرته، وأن أي قرار يصدر المخالفـة لـه سيعد باطلاً، أما بالنسبة للأفراد فإنهم وفقا لصياغة النص غير مقيدين بشيء، حيث لم

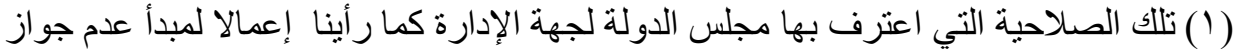

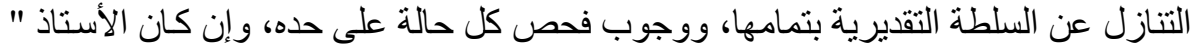

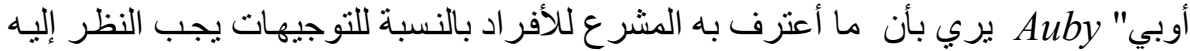

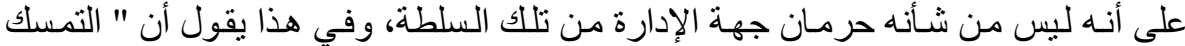
بالتوجيهات يشمل جميع الحالات ولكن في الحدود القضان القائية".

"L'invocabilité de la directive concerne tous les cas mais elle connait des limites résultant de la jurisprudence".

Auby J.-M, , Le décret du 28 nov. 1983,. AJDA 1984, p. 134.

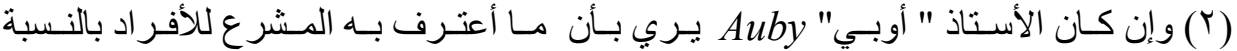

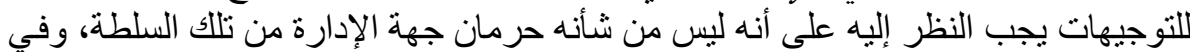

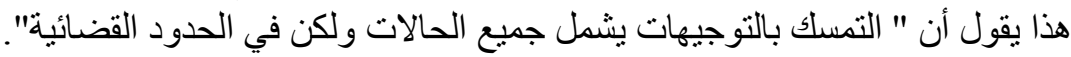

"L'invocabilité de la directive concerne tous les cas mais elle connait des limites résultant de la jurisprudence".

Auby J.-M, , Le décret du 28 nov. 1983,. AJDA 1984, p. 134.

مجلت البحوث القانونيت والإقتصاديت 


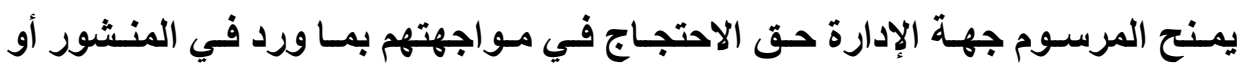

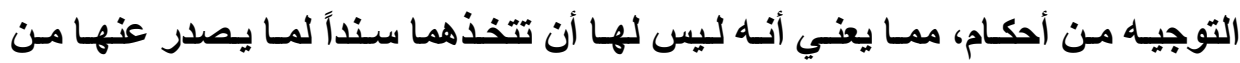

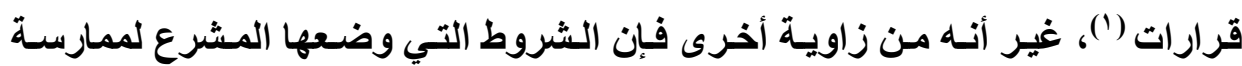

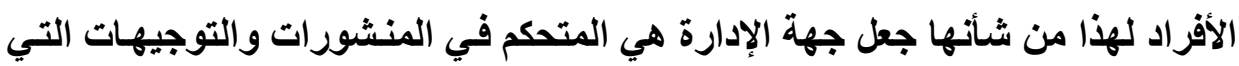
يجوز الاحتجاج بها في مواجهتها، ذلك أن المرسوم وإن كـان قد أعطى للأفراد حق التق

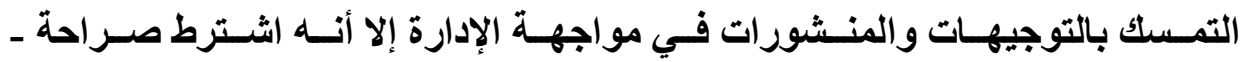

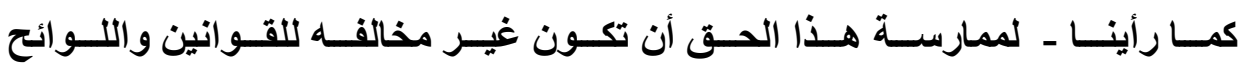

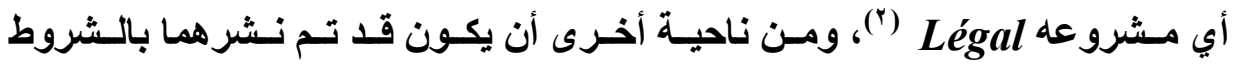

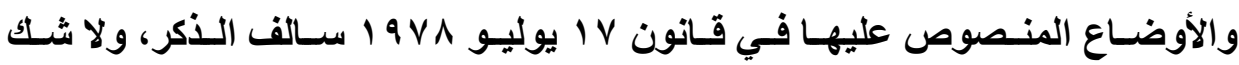
أن مثل هذا الشرط من شـأنه جعل الإدارة هي المتحكم في المنشورات والتوني التهيهات

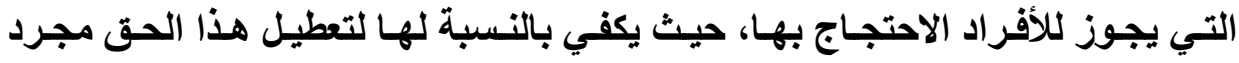

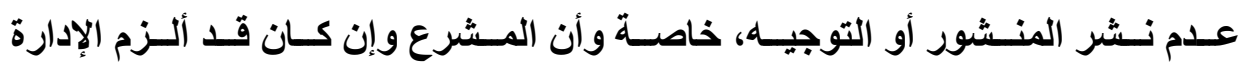

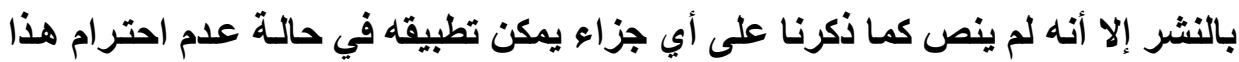

(T) وهو ما حرص مجلس الدولة الفرنسي التأكيد عليه في أكثر من موضع من ذلك على سبيل

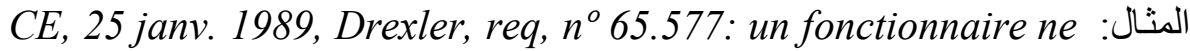
peut se prévaloir d'instructions contraires à la loi pour la révision de sa situation indiciaire; CE. 3 juillet 1991, Hermel, N.P. : un fonctionnaire ne peut invoquer une circulaire reconnaissant un droit à réintégration contraire à un décret; CE. 23 déc. 1994, Commune de Clairvaux d'Aveyron, req. $n^{\circ}$ 974.449. ; CE. 6 sept. 1995, Dominique, req. $n^{\circ} 145.096$. 
الالتزام(')، فضلاً عن أن مجلس الدولة يتشدد كثيراً بشأن النشر حتى يمكن التمسك

$$
\text { بالمنشور أو التوجيه (r) }
$$

ويلاحظ أن مـا جاء بـه مرسوم ب 19 بشأن إمكانية الاحتجـاج بالمنشورات لا

يعد جديداً ذلك أن المشرع بمقتضى نصوص خاصة في مجـالات معينـة اعترف للأفراد بالحق في التمسك في مواجهة الإدارة بالتفسيرات التي سبق وأن أعطتها للنص الذي يتم تطبيقه، وهو ما ظهر بصفة خاصة في مجال الضرائب، بل أن المشرع ذهب في هذا

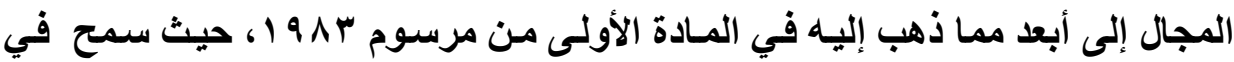
هذا المجال بالتمسك بالمنشور التفسيري حتى وإن كان مخالفا للنص الذي يتم تفسيره، بل وأيضاً إذا حدث وعدلت جهة الإدارة عن تفسير معين لمخالفته للقـانون فبان هذا العدول لا يسري بـأثر رجعي سواء كسان لصالح الممول أو ضده، فطبقاً لنص المـادة

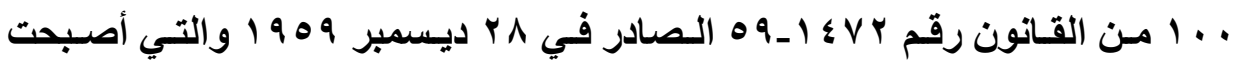
المسادة L.80-A من التقنين الضريبي "إذا تم تطبيق نص ضريبي على ممـول وفقـا لتفسير تم تضمينه منشور أو تعليمات تم نشرها...فإنهله لا يمكن مطالبته فيمـا بعد بأيـة زيادة استناداً إلى تفسير مغاير، كما يحتج أيضا في مواجهة الإدارة وبنفس الشروط والأوضاع، بالمنشورات والتعليمات المنشورة المتعلقة بتحصيل الضرائب أو العقوبـات

$$
\text { (1) الأمر الذي يجعل الإلزام بالنشر دون جدوى أو بعبارة أخرى عديم الآثر. }
$$

Koubi G., Les circulaires administratives, op.cit., p. 302

CE. 31 mai 1989, Castellani, req. $n^{\circ}$ 91.681:" une instruction non publiée ne peut être invoquée"; CE. 18 févr. 1998, Humbert, req. $n^{\circ}$ 139.286:" que si M. Humbert invoque l'art. ler du décret du 28 novembre 1983 (.. .), ces dispositions ne peuvent en tout état de cause recevoir application en l'espèce, les instructions en l'espèce $n$ 'ayant pas été publiées"; CE 18 mars 1992, Ville de Bayeux, p. 1239.

مجلت البحوث القانونيت والإقتصاديت 
الضريبية "(')، ولا شك أن مثل التوجه إنما يهدف في المقام الأول حماية الممولين من أية تغيير يمكن أن يطر أ على مذهب الإدارة في تفسير النصوص، وفي هذا يقول الأستاذ " دوا" Douat أنـه " ليس من العدالـقفي الواقع أن يـدفع المـول ثـن تغير مذهب

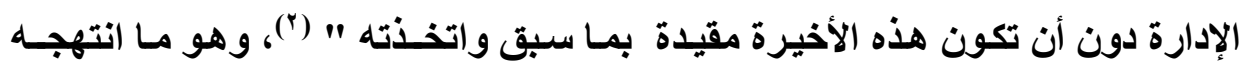
المشرع الفرنسي أيضـا بالنسبة

(1)" Lorsque le redevable a appliqué un texte fiscal selon l'interprétation que l'administration avait fait connaître par ses instructions ou circulaires publiées et qu'elle n'avait pas rapportée à la date des opérations en cause, elle ne peut poursuivre aucun rehaussement en soutenant une interprétation différente. Sont également opposables à l'administration, dans les mêmes conditions, les instructions ou circulaires publiées relatives au recouvrement de l'impôt et aux pénalités fiscales.".

(2)"En effet, il ne serait pas juste que le redevable fasse les frais des variations de la doctrine sans que l'administration soit liée par ses propres positions ". Douat E., Les mérites comparés de l'article L. 8O-A du L.P.F et de l'article ler du décret du 28 novembre 1983 LPA 14 oct. $1991 n^{\circ} 123, p .7$

مع ملاحظة أن مجلس الدولة يميل إلى التتشد بشأن تطبيق حكم المـادة • م من التقنين الضريبي

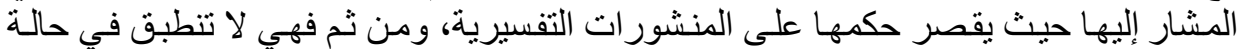
التوجيهات أو التوصيات: C.E. 4 juin 1976, SARL Le Castelet, Rec. p. 294 ، ومن التول

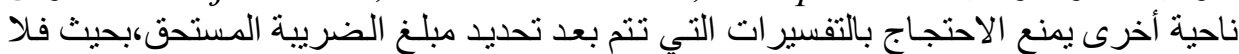
يجوز للممول بعد تحديد المبلغ المستحق عليه وفقا لتفيرات لتفير معين أن يعود ليطالب بإعادة التقدير

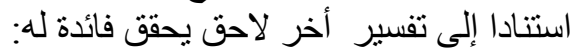

C.E. 24 juin 1968, Rec, p. 385

$$
\text { لمزيد من التفاصيل بشأن المادة L. 8O-A du L.P.F من التقنين الضريبي راجع: }
$$

Douat E., Les mérites comparés de l'article L. 8O-A du L.P.F. et de l'article ler du décret du 28 novembre 1983, LPA 14 oct. 1991, $n^{\circ} 123$, p. 7 et $s$, op.cit; BERN P., La protection du contribuable contre= 


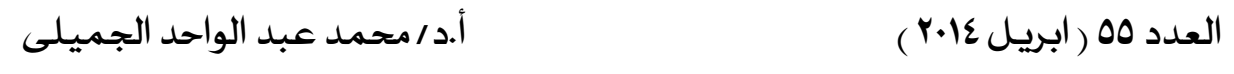

cotisations et contributions لاشـتراكات الـضمان الاجتمـاعي

(') sociales

= les changements de doctrine, op.cit, p. 751; Amselek P., L'opposition à l'administration de sa propre doctrine, les innovations apportées par le décret du 28 nov. 1983 Rev. droit fisc. 1984, n 4, p. 19 et s. ; Heinis M., L'art. ler du décret du 28 nov. 1983 devant le juge de l'impôt ", LPA ler juill. 1994, $n^{\circ}$ 78, p. 7 et s; Collet M., Droit fiscal : PUF, $2 e$ éd., 2009, ; Haïm V., L'article L. $80 \mathrm{~A}$ du Livre des procédures fiscales est-il inconstitutionnel ? : Dr. fisc. 1995, $n^{\circ} 12, p .549$ et s; Droit fiscal général de Lamarque J., Négrin O. etAyrault L., LexisNexis, $2 e$ éd., 2011.

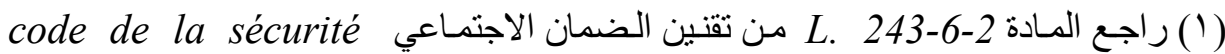
sociale.

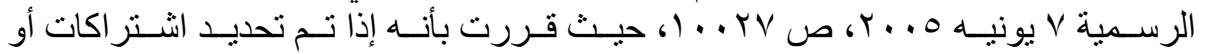

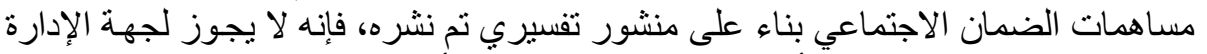

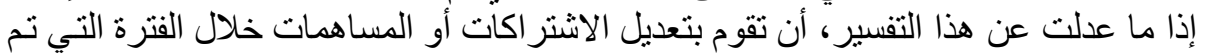

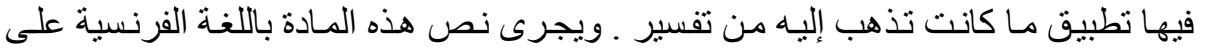

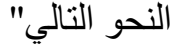

"Lorsqu'un cotisant a appliqué la législation relative aux cotisations et contributions sociales selon l'interprétation admise par une circulaire ou une instruction du ministre chargé de la sécurité sociale, publiées conformément à la loi $n^{\circ} 78-753$ du 17 juillet 1978 portant diverses mesures d'amélioration entre l'administration et le public .. les organismes mentionnés aux articles L. 213-1, L. 225-1 et L. 752-4 ne peuvent procéder à aucun redressement de cotisations et contributions sociales, pour la période pendant laquelle le cotisant a appliqué l'interprétation alors en vigueur, en soutenant une interprétation différente de celle admise par l'administration" 


\section{الاطلب الثاني}

\section{هوقف الفقـه}

قدمنا أن المادة الأولى من مرسوم ب^ه 19 اعترفت للأفر اد بـالحق في التمسك

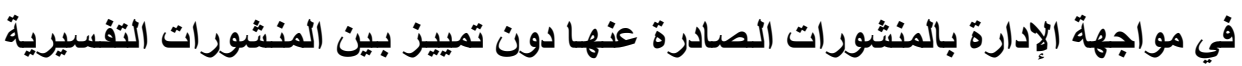

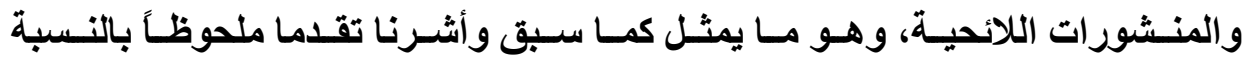
للمنشورات التفسيرية إذا مـا تمت مقارنته باتجاهـات مجلس الدولة وقت صدور هذا المرسوم بالنسبة لهذه النوعية من المنشورات، حيث كان ينظر إليها ـكمـارأينا ـ على أنها تعد كما لو كاتت غير موجودة سواء بالنسبة للقاضي أو بالنسبة للأفراد بل وحتى بالنسبة لـلإدارة نفسها حيث يمكنها التنصل منها دون قيد أو شرط، ولهـذا كـان من الطبيعي أن يثير هذا المرسوم العديد من المناقشات بين الفقهاء لتحديد مضمونه على وجـه الدقة، أو بعبـارة أخرى لتحديــ مـا إذا كـان حق الاحتجـاج في مواجهـة الإدارة بالمنشورات التفسيرية الصادرة عنها من شـأنه أن يغير من طبيعة هذه المنشورات بحيث يتعين النظر إليها على أنها بهذا النص أصبحت ذات طبيعة لاتحية يمكن الطعن عليها مباشرة بتجاوز السلطة. هذا هو مـا دافع عنـه الأسـتاذ ديلفولفيـه Delvolvé في مقالـه حول "صور جديدة للأعمـال الإداريـة الانفراديـة" مؤكداً على أنـه أصبح بصدور هذا المرسوم من من مأن الممكن قبول الطعن مباشرة في هذه المنشورات، تأسيساً على أنها بهذا المرسوم أصبحت تعد بمثابة قرارات لائحية Actes réglementaires (')، وهو مـا أيدته أيضا

(1)Delvolvé P., De nouvelles modalités pour les actes administratifs unilatéraux, D. 1984, p.143, op.cit.

$$
\text { NA مجلتّ البحوث القانونيت والإقتصاديت }
$$


الأستاذة "لوبـاج جيسكا" Lepage-Jessca بقولها " مـن الصعب الاحتفـاظ بحيلة قانونية une fiction juridique تؤدي إلى النظر إلى الأعمال التي يمكن للمتعاملين مع جهة الإدارة التمسك بها، على أنها غير قابلة للطعن فيها.. إن قضاء مجلس الدولنة بالنسبة لقبول الطعن بتجاوز السلطة ضد المنشورات أو التوجيهات غير اللائحية يجب أن يتم التخلي عنه من الآن فصاعدا " (')، وهو ما دافع عنه أيضا الدكتور رأفت فوده، حيث تساعل تعليقا على هذا المرسوم ألا يعد ذلك اعتر (فا تشريعيا لهذه الأعمال بالصفة

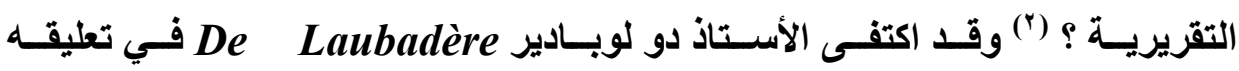
على هذا المرسوم بالقول بأن جهة الإدارة بهذا النص أصبحت مقيدة بمـا اتجهت إليه par sa proper doctrine بأنه - وإن لم يصرح بذلك - يميل إلى أن المنشورات دون تمييز قد تغيرت طبيعتها بعد

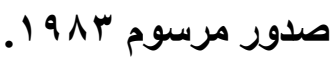

في حين دافع البعض الآخر عن أن اعتراف مرسوم ب919 1 بهذا الحق ليس من شـأن تغيير طبيعة تلك المنشورات، حيث تساعل العميد فيدل Vedel عن فائدة هذا

(2)" il parait plus difficile de maintenir une fiction juridique qui permettrait de regarder des actes dont les administrés peuvent se prévaloir comme non susceptibles de recours ... la jurisprudence du Conseil d'Etat sur l'irrecevabilité du recours pour excès de pouvoir dirigé directement contre une circulaire ou une directive non réglementaire doit être dorénavant abandonnée".

Lepage-Jessca C., Le décret dn28 nov. 1983 concernant les relations entre l'administration et les usagers: une mini-révolution?, op.cit, p. 152.

(Y) د. ر أفت فوده، عناصر وجود القرار الإداري، دراسة مقارنة، دار النهضة العربية، 999 (152،

(3)De Laubadère, Traité de droit administrative, op.cit., ,p.586 
النص معتبراً أن النص بسماحه للأفراد التمسك بالمنشورات في مواجهة جهة الإدارة يعطي الانطبـاع بأنسه يضفي الطبيعـة اللائحيـة عل كافة المنششورات، بيــ أن مـصدر المنشور قد يكون ممن لا يتمتعون بسلطة إصدار اللوائح، ممـا يعني أن المنشور في هذه الحالة سوف يعد مخالفاً للقوانين واللوائح، وهو فرض يستبعد فيه المرسوم نفسه

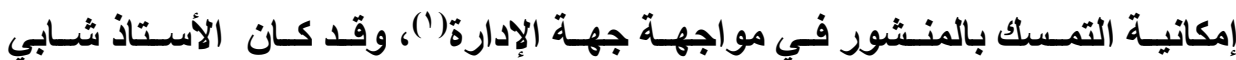
أكثر وضوحا في هذا الخصوص حيث نجده يقرر صراحة بأنها يعد من قبيل Ce serait aller bien loin الذهاب بعيداً تخيلنـا أن نصوص المرسوم قد يفهم منها ضمنا بأنها تعترف بالطبيعة اللائحيـة لجميع المنشورات، حيث قام باستعراض ثلاثة فروض: الأول: يتمثل في أن يكون المنشور ذات طبيعة لاتحية، نظراً لتضمنه أحكاما جديدة، وفي نفس الوقت صادرا ممن يملك السلطة اللائحية، في هذا الفرض فِان النص لا يضيف جديدا، ذلك أن المنشور سيخضع في هذه الحالة لما تخضع لـه اللوائح من أحكام، الثاني: يتمثل في أن يكون المنشور ذات طبيعة تفسيرية ولكن غير مطابق للنصوص التثريعية أو اللائحية التي يقوم بتفسيرها، في هذه الحالة فإنـه سيعد غير مشروع illégale، ومن ثم لا يقيد جهة الإدارة ، بعبارة أخرى لا يمكن الاحتجاج به في مواجهنها inopposable à l'administration ، الفرض الأخيـر: يتمثل في المنشورات التفسيرية المشروعة أي غير المخالفة للقوانين واللوائح، في هذه الحالة فإن الاحتجاج بها في مواجهة الإدارة لن يختلف كثيراً عن التمسك في مواجهتها بالنص الأصلي الذي يقوم المنشور بتوضيحه، مشيراً إلى أنه صحيح أن المنشور التفسيري قد يتضمن الإشارة إلى بعض الإجراءات المتعلقة بالتحضير للقرار واتخـاذه إلا أنها يشكك

(1)Vedel G. op, cit., P. 261.

راجع أيضنأ:

Noël G., Les vicissitudes des circulaires opposables, op.cit, p.38.

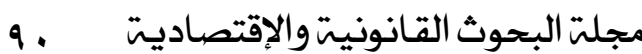


في أن يكـون ذلك سـبباً يـؤدي إل بطـلان القرار الــي يـتم اتخـاذه دون مراعـاة هذه الإجراءات طالمـا أن مضمونه يتفق مـع النصوص التشريعية أو اللائحية التي يتولى المنشور تفسير ها أو بيان طريقة تنفيذها.

وقد انتهى الأسـتاذ شـابي Chapus من هذ التحليل إلى طرح تسـاؤل أعمق

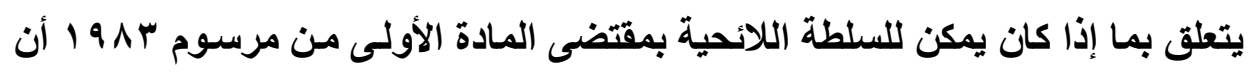

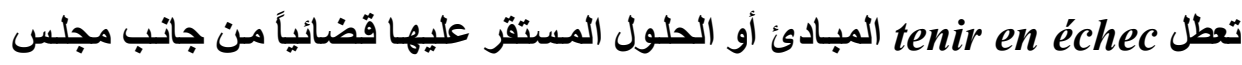
الدولة، مشيرا إلى أن المجلس سبق وأن أجاب عن هذا التساؤل بـالنفي وذلك بالنسبة

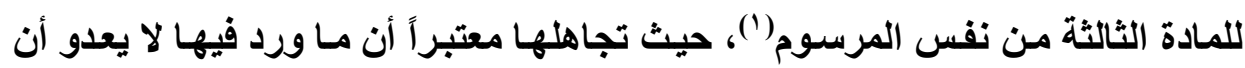
يكون تكريسا لائحياً لمبدأ قانوني عام (†)، مما يعني أن المادة الأولى من نفس المرسوم

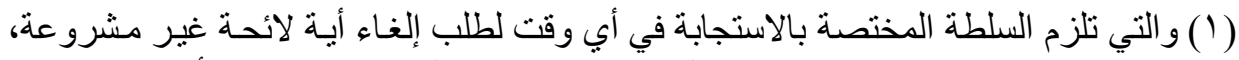

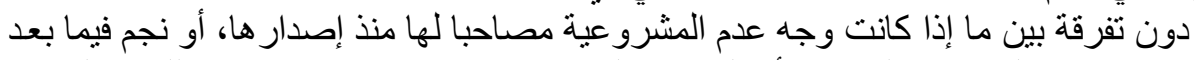

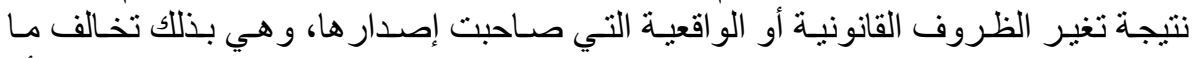

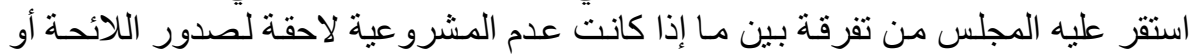

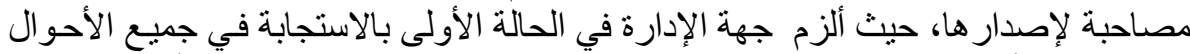

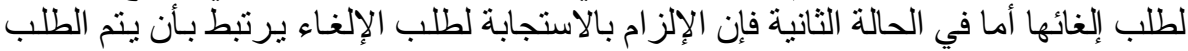

$$
\text { خلال مدة الطعن القضائي. راجع: }
$$

Long M. et autres, Les grands arrêts de la jurisprudence administrative, 10e édition, Sirey, 1993 op.cit,p736

وسوف نعود إلى هذا النص مرة أخرى عند تناول موقف القضاء الإداري من نص المادة الأولى (2)CE 15 avril 1988, Société Le Tahiti Rec. P.140, LPA 1988, no 148, note Frier

$$
\text { راجع أيضًا: }
$$

C.E. Ass. 3 févr. 1989, Compagnie Alitalia, Rec. p. 44 ;AJDA 1989, p. 387, note O. Fouquet; RFDA 1989, p. 391, concl. Chahid-Nouraï N. et p. 442, note Beaud O.-; C.E. 1" mars 1989, Syndicat CFDT des arsenaux du Val-de-Marne. Dr. adm. 1989, $n^{\circ}$ 209, RDP 1989, p. 1488.

مجلة البحوث القانونيت والإقتصاديت 
لن تكون بالنسبة للأستاذ "شابي" Chapus أوفر حظاً فيمـا لو عرضت مشروعيتها على المجلس (')، بمعنى أن المجلس سيقوم في تقديره بتجاهل الحكم الوارد فيها لكونـه سيعد منـاقض لمـا استقر عليه مـن مبـادئ بشأن التمييز بين المنشورات التفسيرية والمنشورات اللائحية.

\section{الإطلب الثالث \\ هوقف القضشاs}

سنعرض" أولاً" لموقف القضاء العادي، ثم نعقبه ببيان موقف القضاء الإداري .

\section{الفرع الأول}

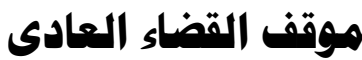

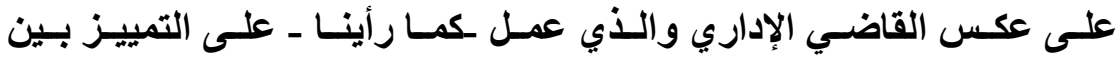

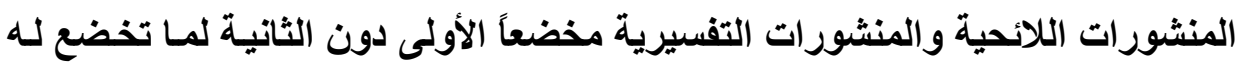
القرارات اللائحية من أحكام، أظهر القاضي العـادي الفرنسي سواء في ذلك المدني أو الجنائي تثدده بشأن تلك التفرقة، حيث فضل النظر إلى المنشورات على أنها لا تعدو

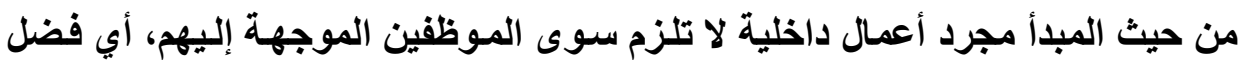
كقاعدة السير في الوقت الذي كان ينظر القضاء الإداري للمنشورات على أنها لا تتمتع بأيـة قيمـة قانونيـة في مواجهة الأفراد(؟)، وهو مـا حرصت محكمـة النقض الفرنسية

(1) Chapus R., Droit administratif, op.cit,p.460.

(2) Blumann C., L'application des circulaires administratives par le juge judiciaire, AJDA 1972, p264.

" la jurisprudence judiciaire replonge presque un demi-siècle en arrière à une époque où il était entendu par la quasi totalité des auteurs que les circulaires étaient dépourvues de toute valeur juridique" 


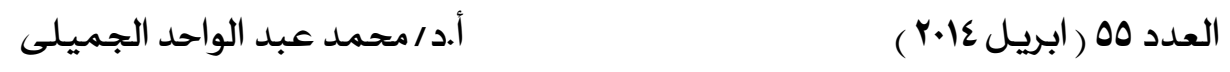

التأكيد عليه سواء في المواد الجنائية حيث لم تعتبرهـا مصدرا للعقاب أو الاعفـاء منـه

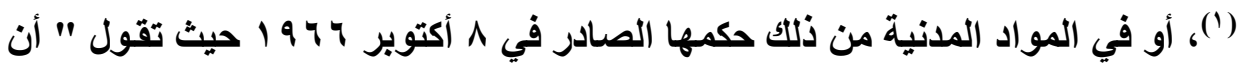

المنشور الوزاري يعد عمل داخلي محض، ومن ثم لا يمكن نتيجة للفصل بين السلطات

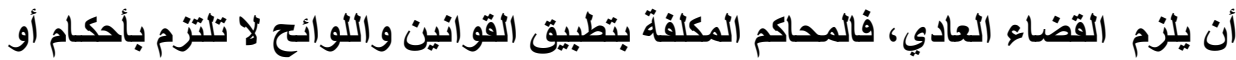

بنود المنشور"()، وفي حكم أخر تقرر صراحة بأن" المنشور لا يلزم سوى الموظفين

الموجه إليهم، فهو لا يمكن أن يحكم الاتفاقات بين الأفراد"(").

(1) (1) راجع عل سبيل المثال: (1)

Cass. crim, 18 juin 1 969, Balestas,JCP 1970, II. 16531, note Despax, ;- Cass. crim. 31 mai 1962, Audebert, JCP 1962, II, 12760, note Vivez;- Cass. crim. 20 févr, 1979, Viala, Bull. crim. $n^{\circ}$ 75, p. 206 ; Cass. crim. 28 oct, 1986, Leroy el SA Entreprises Moes, Bull. crim. $n^{\circ}$ 311, p. 791.

(2)" L'instruction ministérielle est un acte ..de caractère purement interne, qui ne saurait du fait de la séparation des pouvoirs s'imposer aux juridictions de l'ordre juridique. Les tribunaux chargés de l'exécution des lois et règlements ne sont pas liés par les termes d'une circulaire"

Cass. civ. 8 oct. 1965, Moulin c/V. de Rennes, BuII. cass. $n^{\circ} 101$, p. 81.

(3)"Une telle circulaire n'oblige que les fonctionnaires auxquels elle est adressée et ne saurait régir les conventions entre particuliers".

Cass. civ, 6 oct 1966, Bull. cass, I, $n^{\circ} 456, p .346$.

$$
\text { راجع أيضأ: }
$$

Cass civ. 23 mars 1982, Comité des locataires de l'immeuble sis 14, rue Frédéric-Lemaitre à Paris c/ OPHIM de la ville de Paris, Bull. civ. III, p. 54, n" 77 ; Cass. com. 13 nov, 1990, Société Trans Sud c/ Association professionnelle des commissaires de transport de la région Nord-Picardie, BulI. civ, IV, p. 190, $n^{\circ} 272 .=$

مجلة البحوث القانونيتة والإقتصاديت 


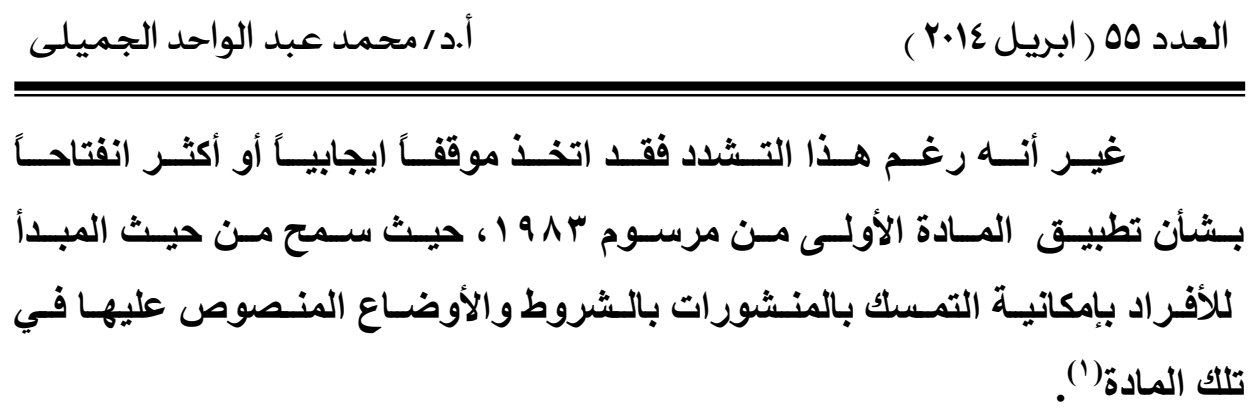

= لمزيد من التفاصيل بشأن موقف القاضي العادي بالنسبة للمنشورات راجع: Blumann C., L'application des circulaires administratives par le juge judiciaire», AJDA 1972, p. 263 et s; Fourgoux J-C. , Répression des fraudes, la réglementation par voie de circulaires , Gaz. Pal. 1963, 2, doctr., p. 43 ; Brando S., L'autorité des circulaires administratives en droit pénal, Travaux et recherches de la Faculté de droit de Paris, PUF 1967; Prétot X., De l'esprit des circulaires et instructions ... et des rapports qu'elles entretiennent avec le droit social, RJS 1997-6, p. 415 et s. ; Van Lang A., Juge judiciaire et droit administratif, LGDJ, 1996, p 203 et s.; Chapus R., Droit administratif, op.cit, p.459.; Vedel G. op, cit., P. 262.

$$
\text { (1) و هو ما ظهر بصفة خاصة في المجال الضريبي، راجع: }
$$

Cass. Com. 2 juill, 1991, Compagnie générale des eaux c/ D.G.I., D. 1991, IR, p. 219; Cass. Com, 23 nov. 1993, Kinoo c/ Receveur principal des impôts de Maubeuge Sud, D. 1994, IR, p. 6 :" viole (L'art. ler du décret du 28 nov. 1983) la Cour d'Appel qui, pour déclarer la procédure d'imposition régulière, retient que L'instruction, en cause est une mesure d'ordre intérieur dont l'absence d'application ne saurait etre invoquée par le contribuable".

Prétot X., De l'esprit des circulaires et instructions..et des rapports qu'elles entretiennent avec le droit social », RJS.1997, p. 415 et s. 


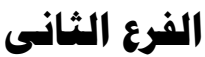

\section{هوقف القضاء الإداري}

بالرجوع للقضاء الإداري الفرنسي نجد أنه لم يتخذ موقفاً موحداً، حيث اتخذت

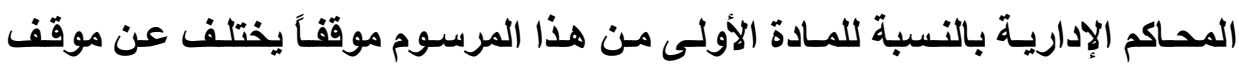
مجلس الدولة، فبينمـا اتجهت الأولى بصفة عامـة إلـي إعمـال حكم المـادة الأولى مـن

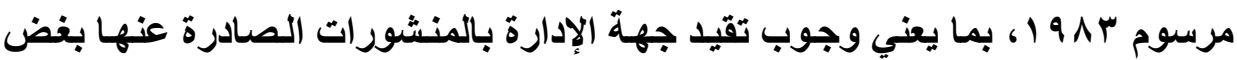
النظر عن طبيعتها القانونية، وأن للأفراد حق التمسكك بها في مواجهتها شريطة أن I I V^ تكون مشروعة وأن يكون قد تم نشرها بالأوضاع المنصوص عليها في قانون على التفصيل السابق(')، نجد أن مجلس الدولة وإن كان قد يفهم من بعض أحكامـه أنـه قـ أظهر ضمنياً إعماله لنص المادة الأولي من مرسوم بـ19 إيث استتد في رفضه التمسكك بالمنشور في هذه الأحكام إلى كونـهـ يعد مخالفـاً للقوانين واللوائح()، إلا أن الغالبيـة العظمى مـن أحكامـه تظهر بجـلاء تجاهلـه تمامـا لحكم المــادة الأولى مـن هذا المرسوم، حيث ظل متمسكاً بموقفه السابق عل صدور هذا المرسوم أي بالتفرقة في

(1) (1) (1) (1)

T.A.Rennes 29 janv.1987,Dame Louarn,Rec. p.587;- T.A. Nice 11 juin 1987. Syndicat des commerçants non sédentaires des Alpes-Maritimes, JCP 1988,II, 21041, concl. Caldero N..;- T.A. Pau 3 janv.1989, Bilbao,Rec p.375;- TA Marseille 11 déc 1987, Bernardi,Rec. p. 494; JCP 1988, suppl. $n^{\circ}$ 4, note Pacteau B;- TA Pau, 3 janvier 1989, Lorente Bilbao, Rec. p. 375.. ;-T.A. Clermont-Ferrand, 3 avril 1990, Gamet, AJDA 1990, p.643,obs.Briseul J-P.

(2)CE 16 juin 1986,Henimann, Rec. p.464;- 18 mars 1992, Ville de Bagneuxx, Rec. p.662.

مجلت البحوث القانونيت والإقتصاديت 9 
هذا الخصوص بين المنشورات التفسيرية والمنشورات اللائحيـة، مقررا صراحة عدم

إمكانية التمسك بالمنشورات التي تفتقد الصفة اللائحية (')، حتى وإن تم نشرها()،

وهو مـا يفسر قيامـه دائمـاً إذا مـا تـم الطعن أمـــهـ في الأحكـام الـصادرة مـن المحـاكم

الإدارية، والتي سمحت بإمكانية التمسكك بالمنشورات التفسيرية استناداً لنص المـادة

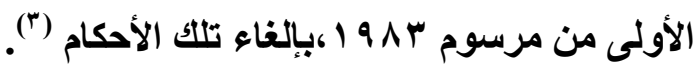

(1)CE 27 mai 1987,Arnaudies, Rec. P.187: " ne peuvent être invoquées les dispositions d'une circulaire (..) qui sont dépourvues de toute valeur réglementaire et ne peuvent être utilement invoquées par le requérant à l'appui de sa demande".

CE 19 juin 1992,Départ. du Puy-de-Dôme, Rec. p.237,AJDA 1992,p.528,RFDA 1993,p.689,concl.Pochard M.;- CE 26 oct.1992, Jonquet,Rec. p.662;- C.E. 19 juin 1992, Bouchon, AJDA 1992, p. 528 , RFDA 1993, p. 689, concl. Pochard M.; C.E. 31 juill, 1992. Kizil, .Rec. p. 1240;- C.E. 6 mai 1996, Association Aquitaine Alternatives, Rec. p. 144;- CE 1er décembre 1997, Fédération des syndicats chrétiens de l'Équipement, Rec. p. 451.

(2) CE, 22 février 1993, Mme Prulière, Quot. Jur., 22 juin 1993, p. 4 ;CE, 25 avril 1994, Ministre de l'Éducation Nationale, Rec. p. 189.

(3) CE, 9 octobre 1996, Moyo, Rec. p. 666, Dr. adm., 1997, $n^{\circ} 12$.

CE, 19 juin 1992, Département du Puy-de-Dôme, Rec. p. 237; -CE, 26 octobre 1992, Jonquet, Rec. p. 662 ; CE, 31 juillet 1992, Kizil, Rec. p. 662 ; CE, 6 mai 1996, Association Aquitaine Alternatives, Rec. p. 144, CJEG, 1997, p. 9 ; CE, 22 février 1999, Ép. Useyin, Dr. adm., 1999, $n^{\circ}$ 164

مجلت البحوث القانونيت والإقتصاديت 9 
ولا شـك أن هـا التجاهـل مـن جاتب مجلس الدولـة للحكم الـوارد في المـادة الأولى من مرسوم بـ1919 واحتفاظه بقضائه التقليدي بشأن المنشورات، وإن كـان من شـأنه في الواقع أن يظهر المجلس كمقـاوم للحمايـة التـي هـف هــا المرسـوم إلـى تحقيقها للمتعاملين مع جهة الإدارة من خلال السماح لهم - بشروط معينة على التفصيل السـابق - بالتمسكك فـي مواجهتهـا بالمنـشورات الـصادرة عنهـــا دون تمييـز بـين مـا إذا كانـت تفسيرية أو لائحيـة ــ خاصـة وأن القضـاء العـادي رغـم تشـدده بـشأن

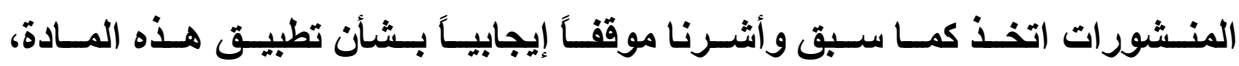
كمـا أن المحـاكم الإداريـة هـي الأخرى لـم تتردد في إعمـال حكمهـا ــ إلا أنـه يبـدو أن المجلس اعتبر أن قضائه بشأن المنشورات قد أرسى مبدأ قانوني عام ومن ثم لا يجوز وفقاً لتدرج القواعد القاتونية مخالفته من خلال عمل لائحي صادر عن السلطة التنفيذية

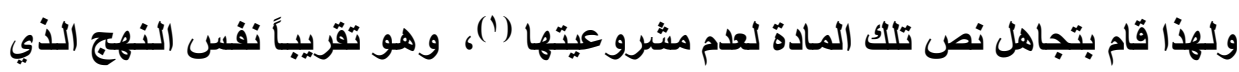
انتهجه - وإن لم يصرح بذلك ـ بالنسبة للمادة الثالثة من نفس المرسوم ولكن بأسلوب

$$
\begin{aligned}
& \text { Robineau Y., op.cit, p. } 91 .
\end{aligned}
$$

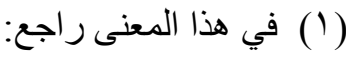

$$
\begin{aligned}
& \text { لمزيد من التفاصيل بشأن القيمة القانونية للمبادئ العامة للقانون راجع: }
\end{aligned}
$$

Isaac G., les principes généraux du droit », Juris-classeur contentieux administratif; Jeanneau B. , La théorie des principes généraux du droit à l'épreuve du temps, EDCE 1981.1982, n' 33. ; Jeanneau B.; Les PDG dans la jurisprudence administrative, Sirey 1954; Chapus R., De la valeur juridique des $P G S$ et des autres regles jurisprudentielles du droit administratif, D 1966, p.99-Droit administratif, op.cit, p.72 et s.

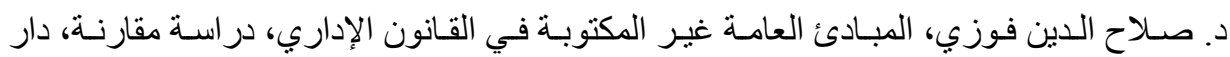

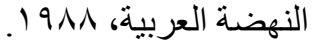


مختلف، ففي قضية شركة طيران Alitalia (')، والتي تتلخص وقائعها في أن شركة

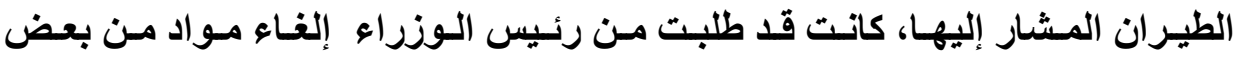

La taxe sur la valeur ajoutée ( المراسيم المتعلقة برسم القيمة المضافة IV T.A.A)

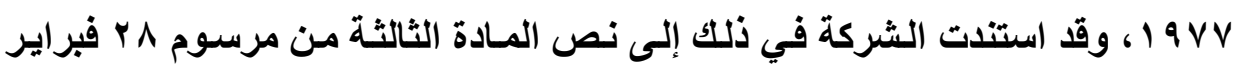

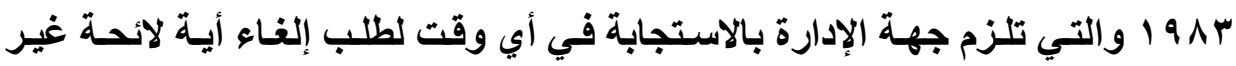
مشروعة، دون تفرقة بين ما إذا كاتت وجه عدم المشروعية مصاحباً لها منذ إصدارها، أو نجم فيما بعد نتيجة تغير الظروف القانونية أو الواقعية التي صاحبت إصدارها")، إلا أن رئيس الوزراء رفض الاستجابة لطلب الشركة، وعندما عرض الأمر على مجلس الدولة بناء على طعن الثركة في هذا القرار، لم يشأ المجلس مناقثة مشروعية المـادة

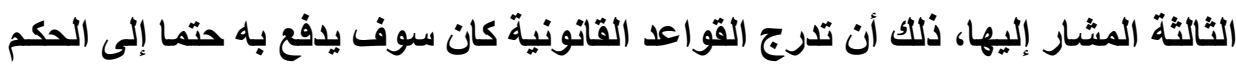

(2)C.E. Ass. 3 févr. 1989, Compagnie Alitalia, Rec. p. 44 ;AJDA 1989, p. 387, note Fouquet O.; RFDA 1989, p. 391, concl. Chahid-Nouraï N. et p. 442, note Beaud et Dubouis LPA 1988, $n^{\circ} 148$, note Derouin, R.T.D.E. 1989, 509, note Vergès, Les grands arrêts de la jurisprudence administrative, 10e édition, Sirey, 1993 op.cit,p731.

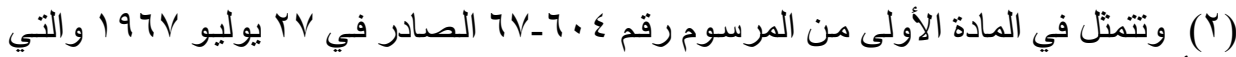

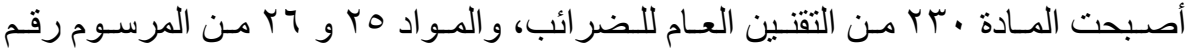

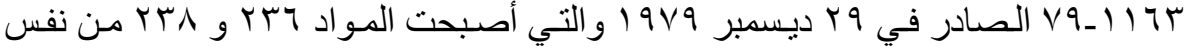

(َ) ويجري نص المادة الثالثة باللغة الفرنسية على النحو النال:

" L'autorité compétente est tenue de faire droit à toute demande tendant à l'abrogation d'un règlement illégal, soit que le règlement ait été illégal dès la date de sa signature, soit que l'illégalité résulte des circonstances de droit ou de fait postérieures à cette date".

مجلت البحوث القانونيت والإقتصاديت 
بعدم مشروعيتها، لمخالفتها للمبادئ التي استثر عليها في هذا الخصوص، والتي كاتت تتمثل في التفرقة بشأن الاستجابة للطلبات التي تقدم للجهات الإداريـة بإلغاء القرارات اللائحية غير المشروعة، بين ما إذا كان وجه عدم المشروعية لاحقا لصدور اللائحة أو مصاحباً لإصدارها، حيث ألزم جهة الإدارة في الحالة الأولى بالاستجابة دون التقيــ بمدة الطعن القضائي لطلب إلغائها، أما في الحالة الثانية فإن الإلزام بالاستجابة لطلب الإلغاء يرتبط بميعاد الطعن القضائي بمعنى أنـه يتعين أن يتم الطلب خلال مدة الطعن القضائي")، ولكنه في نفس الوقت وجد أن الحكم الذي أوردتـه تلكك المـادة يعد حكماً

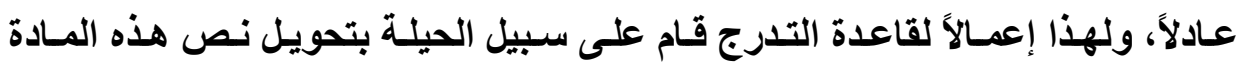

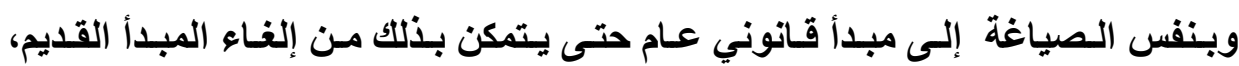
ثم بعد ذلك قرر بأن نص المادة الثالثة من المرسوم لم يضف جديدا ذلك أنها مستوحى

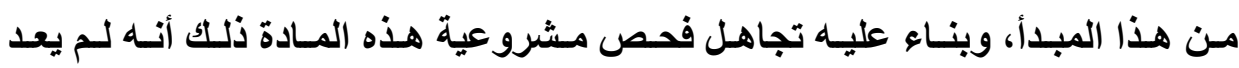
بحاجـة إليها، بعبارة أخرى اعتبر أنها كمـا لو كانت غير موجودة، وقام بـالحكم في القضية وفقاً للمبدأ القانوني الجديد(؟)، ويطلق الأستاذ شابي على هذا الأسلوب في عمل

Long M. et autres, Les grands arrêts de la jurisprudence administrative, 10e édition, Sirey, 1993 op.cit,p736; Chapus R., Droit administratif, op.cit ,p.606 et s...

$$
\text { ومن أحكام المجلس راجع: }
$$

CE sec. 30 janv.1981, Ministère du travail, Rec. P. 32, cocl. Hagelsteen, AJDA 1981,245, chr. Feffer et Pinault, D.1981, IR, p.277, obs. P.D. , D.1982, p.37, note Auby J.M., Dr.ouvr., 1981, p. 265, note Loschak.

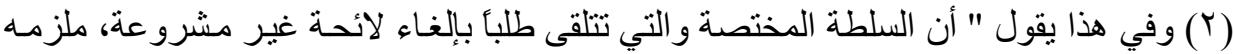

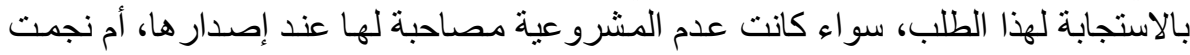

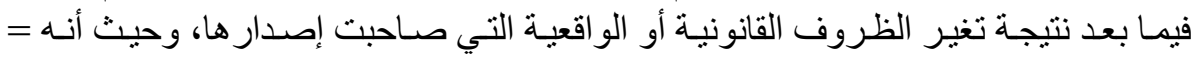




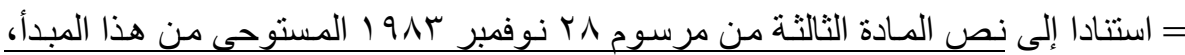

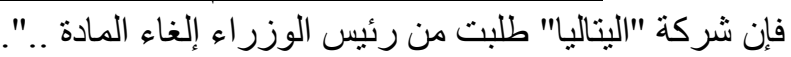

" considérant que l'autorité. compétente, saisie d'une demande tendant à l'abrogation d'un règlement illégal, en tenu d'y déférer, soit que ce règlement ait été illégal dès la date de sa signature, soit que l'illégalité résulte de circonstances de droit ou de fait postérieures à cette date, qu'en se fondant sur les dispositions de I·art. 3 du décret du 28 novembre 1983..qui; $s$ 'inspirent de ce principe, la compagnie alitaliaa demande.. au Premier ministre d'abroger..."

$$
\text { راجع أيضا في نفس المعنى: }
$$

C.E. 1" mars 1989, Syndicat CFDT des arsenaux du Val-de-Marne. Dr. adm. 1989, $n^{\circ}$ 209, RDP 1989, p. 1488;- C.E. A'lS. 23 juin 1989, Bunoz. p. 144; AJDA 1989, p. 627, concl. Faugère J.-P. ; C.E. Ass. 20 déc. 1995, Mme Vedel et Jannot, Rec.p. 440, AJDA 1996, p. 124, chron.. Stahl J-H et Devaux D. ;LPA 26 juill. 1996, p. 25, note Rouvillois F. ; EDCE 1996, $n^{\circ} 47, p 360$.

(1) Chapus R., Droit administratif, op.cit,p.93.

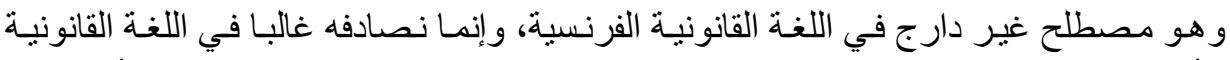

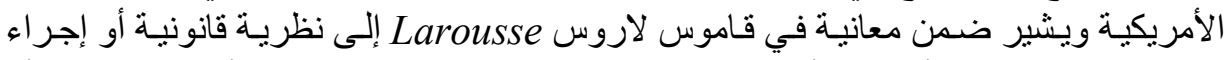

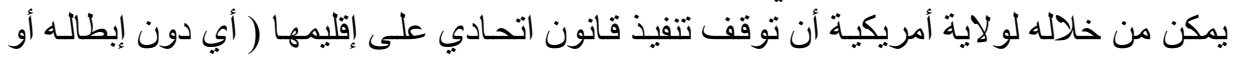

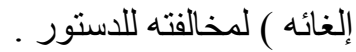

"Procédé par lequel un État américain suspendait sur son territoire l'exécution d'une loi fédérale qu'il déclarait contraire à la Constitution".. http://www.larousse.fr/dictionnaires/francais/

$$
\text { لمزيد من التفاصيل بشأن هذا المصطلح راجع المواقع الالكترونية التالية: }
$$

http://en.wikipedia.org/wiki/Nullification. http://www.thefreedictionary.com/nullification

$$
\text { مجلة البحوث القانونيت والإقتصاديت . . 1. }
$$


وبعيداً عن موقف مجلس الدولة الفرنسي من بعض مواد هذا المرسوم ، فإن

هذا الأخير في الواقع ومنذ ظهوره يثير تساؤلات حول مدى دستوريته ، ذلك أن نطاق تطبيقه كان يمتد ليشمل بالإضافة إلى إدارات الدولة تلك التابعة للأشخاص المعنويـة المحلية، وهو ما قد يتعارض مع نص المادة ؛ ب من الدستور و التي تجعل من المجالات

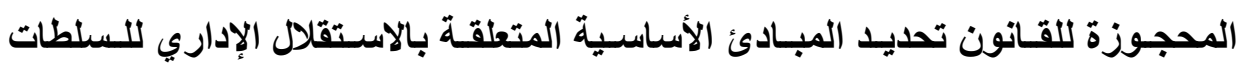

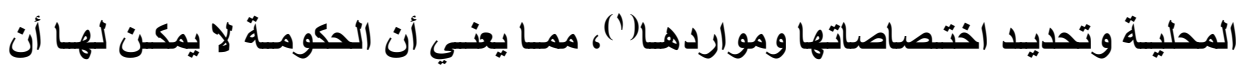
تقرض قواعد إلا على الإدارات التابعة للاولية دون تلكت التابعة للوحدات المحلية، وقد اند حرص الاستاذ ديلفولفيه Delvolvé التأكيد علي هذا المآخذ حيث يقول " أن تغطية

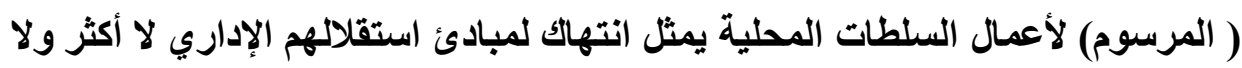
أقل"(")، ولعل هذا أيضا يعد من ضمن الأسباب الرئيسية التي دفعت بمجلس الدولة وإن لم يصرح بذلك إلى تجاهل أو تعطيل هذا المرسوم.

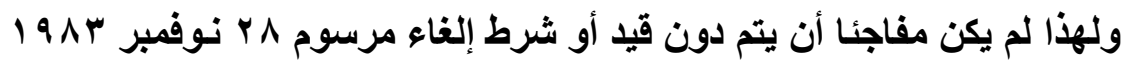

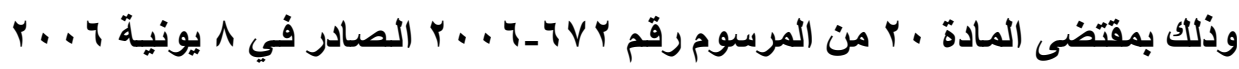

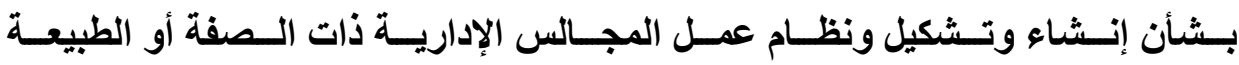

(1) حيث كان يجري نصها باللغة الفرنسية على النحو النالي:

" La loi détermine les principes fondamentaux ...de la libre administration des collectivités territoriales, de leurs compétences et de leurs ressources"

(2) " en couvrant des actes des collectivités locales, il atteint les principes de leur libre administration ni plus ni moins»

Delvolvé P., De nouvelles modalités pour les actes administratifs unilatéraux, op.cit, p. 142.. 


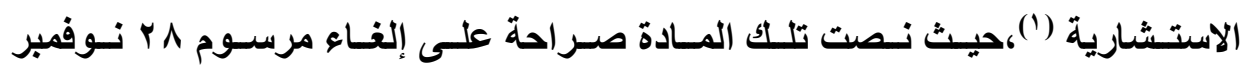

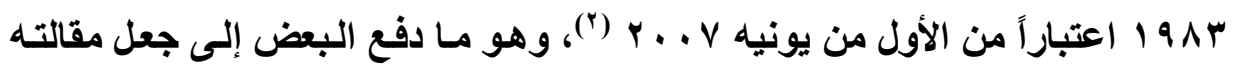
تحمـل عــوان يعبـر عـن الابتهـاج بإلغــاء هـا المرسـوم، مـن هـؤلاء الأسـتاذ كومبـو Combeau

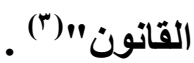

(3)Décret $n^{\circ}$ 2006-672 du 8 juin 2006 relatif à la création, à la composition et au fonctionnement de commissions administratives à caractère consultatif, J.O.9 juin 2006, p.8706.

(4) Art.20 "Le décret du 28 novembre 1983... est abrogé à compter du ler juillet 2007".

( $\left.{ }^{\top}\right)$ Combeau P., Le décret du 28 novembre 1983 est mort, vive la loi ?, AJDA 2006. 1745.

راجع أيضًا:

Le Pors A., Chronique d'une mort annoncée : le décret du 28 novembre 1983, JCP Adm., $n^{\circ}$ 6, 2007. 2021.

مجلتة البحوث القانونيت والإقتصاديت 1. 


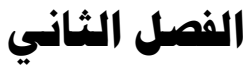 \\ النظام القانوني للانشنورات الإدارية في فرنسا

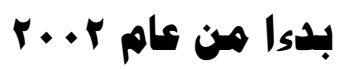

قدمنا أن الاعتماد على مضمون المنشور لتحديد مـا إذا كان قد أضـاف جليدا،

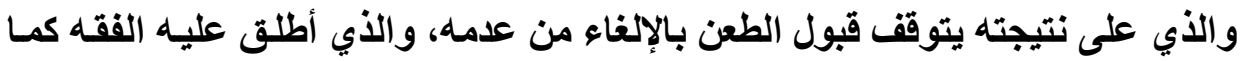

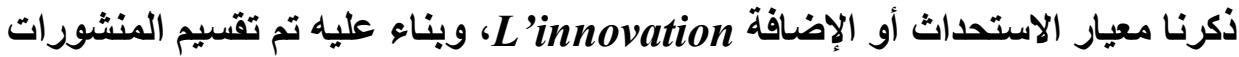

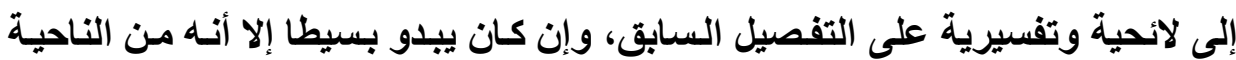

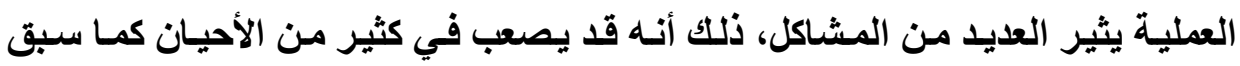

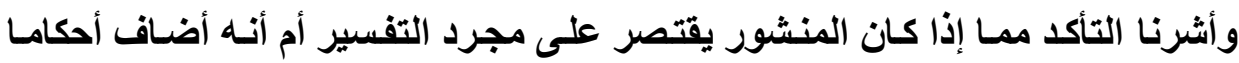

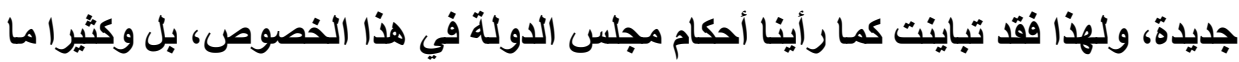

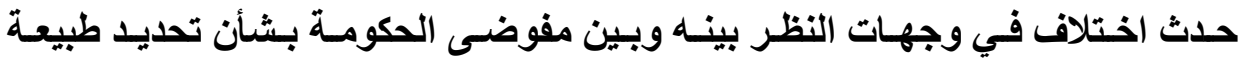
المنشور المطعون فيه، فضلاً عن ذلك فقد أظهر القاضي الإداري كمـا رأينـا في تطبيقه

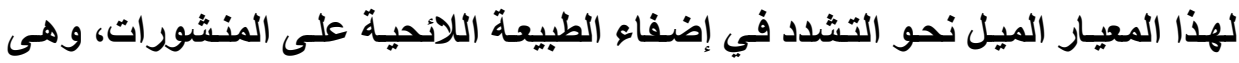

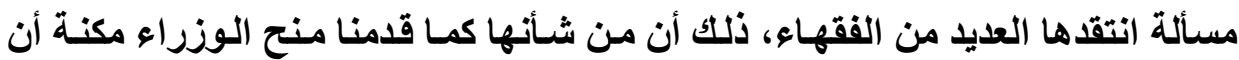
يمنحوا لأنفسهم عن طريق المنشورات سلطة لائحية واقعية تجـاوز الإطار المحديد

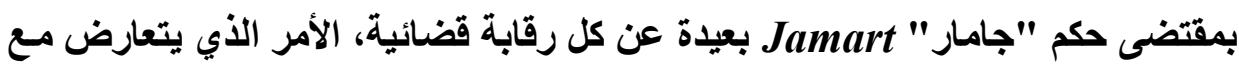

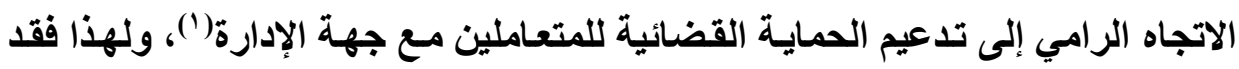

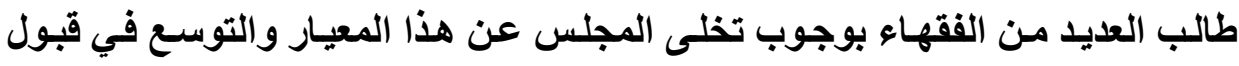

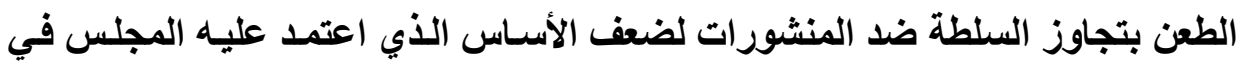

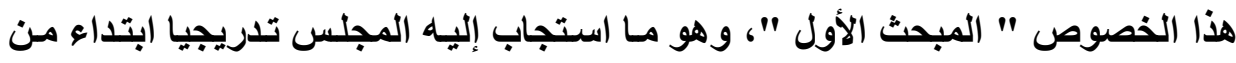
عام 191V 1، حيث بـأ مـن العـام الشار إليـه التمهيد لفكرة الطبيعة الآمرة للمنشيهور

(1) راجع فيما سبق، ص بـ وما بعدها، ص rه

مجلتة البحوث القانونيت والإقتصاديت . 1 
كمعيار لقبول الطعن بتجاوز السلطة أو بالإلغاء ضـ المنشورات، إلى أن استقر نهائيا

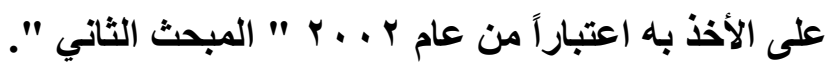

ولم يقف التطور عند هذا الحد، ذلك أن المشرع كمـا سبق ورأينـا في الفصل

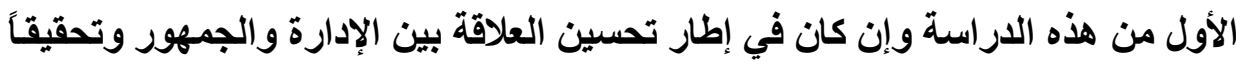

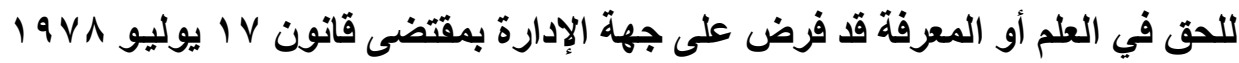

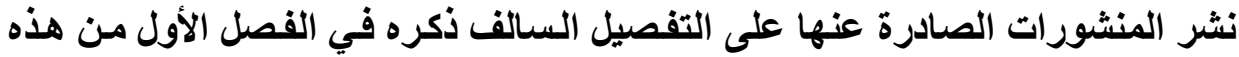

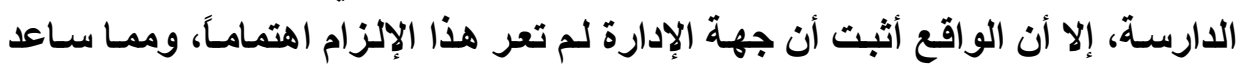

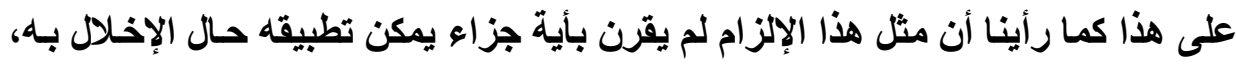

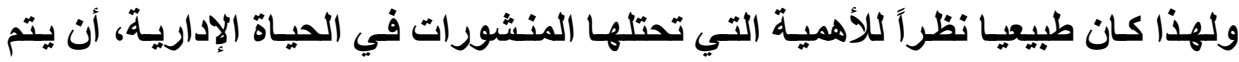

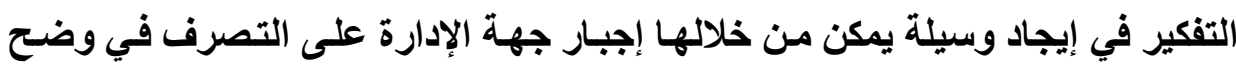

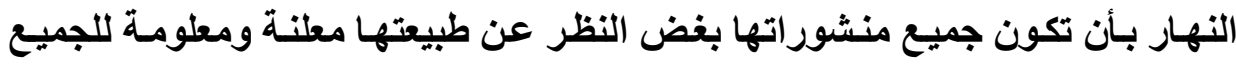

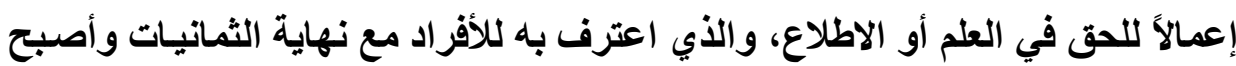

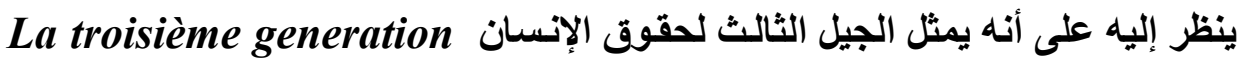
de droit de l'homme

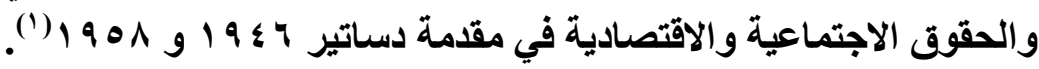

وقـد جـاءت المبـادرة مـن جانب الحكومـة المركزيـة حيـث قـام رئسيس الـوزراء

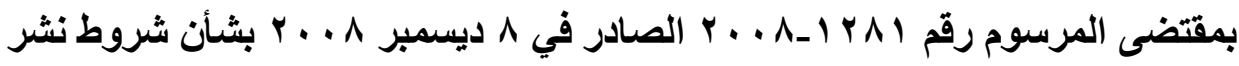

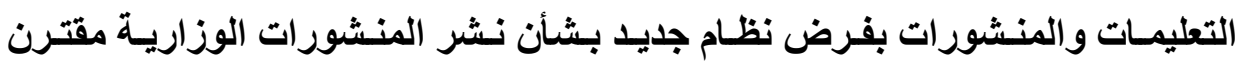

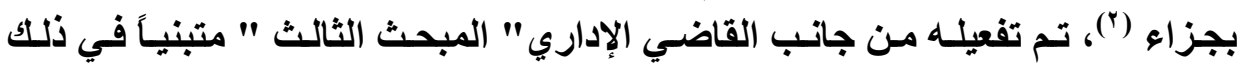

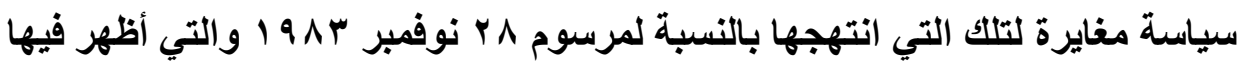
تجاهله للأحكام الواردة فيه على النحو السالف بيانه في الفصل الأول.

(1) Braibant G., Droit d'accès et Droit à l'information, mél. Charlier, 1981, p. 701.

(2) Décret $n^{\circ} 2008-1281$ du 8 décembre 2008 relatif aux conditions de publication des instructions et circulaires, J.O. 10 déc. 2008; AJDA 2008, p. 2309.

$$
\text { مجلتة البحوث القانونيت والإقتصاديت ـ 1 }
$$




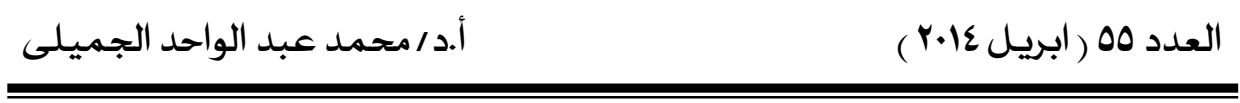

المبحث الأول

ضعف الأساس الذي اعتهد عليه هجلس الدولة

بشأن تقسيم المنشورات إلى لائحية وتفسيرية

لاثثك أن معيار الإضـافة أو الاستحداث الذي اعتمد عليه القاضسي الإداري في

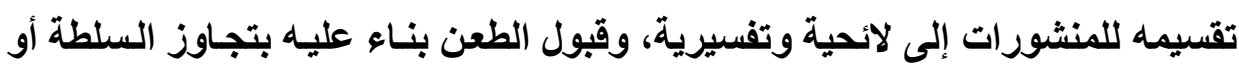

الإلغاء ضد الأولى دون الثانية، ينطلق من فرضية Postulat أن المنشورات التهبية وفيول التفسيرية

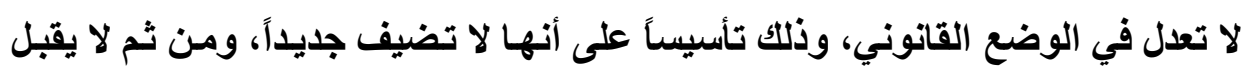

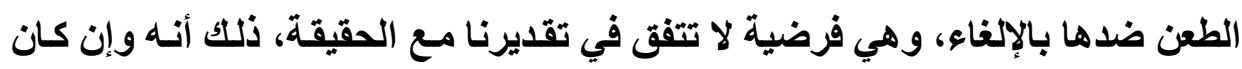

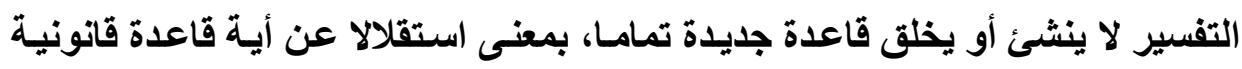

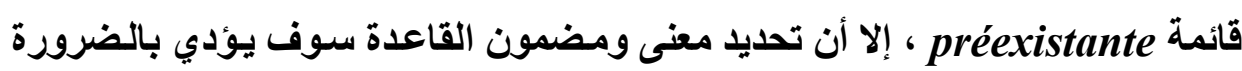

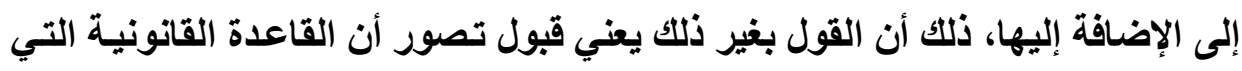

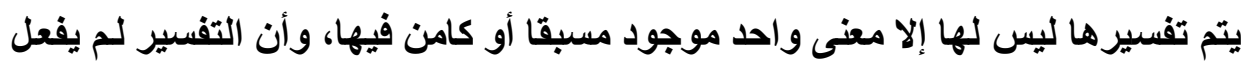

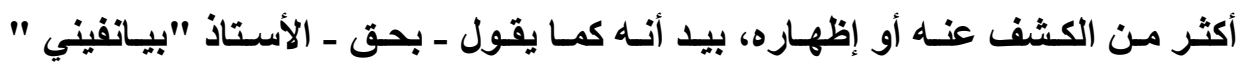
فienvenu

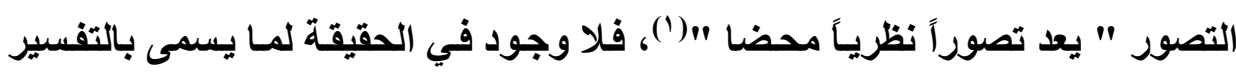

cette conception " relève de la pure spéculation ".

Bienvenu J-J., L'interprétation juridictionnelle des actes administratifs et des lois : sa nature et sa fonction dans l'élaboration du droit administratif, Thèse, Paris 2, 1979, p. 142.

مجلت البحوث القانونيت والإقتصاديت ــ 
المطلق L'interprétation pure (')، ذلك أنه فيمـا عدا بعض الحالات الاستثنائية، فإن القاعدة القانونية تتضمن دائما أكثر من مغنى، ومن ثم فإن قيام الرئيس الإداري باختيار واحدا من بين كل التفسيرات الممكنه، والقطع بأنه التفسير الذي يتعين على لته

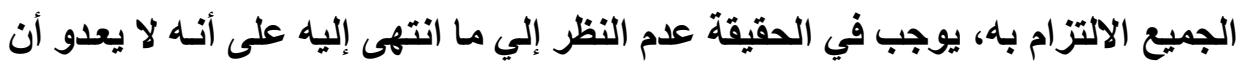

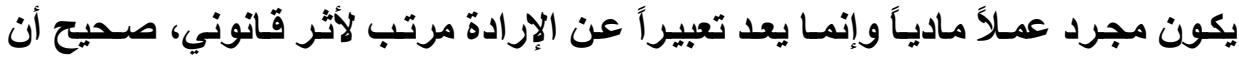
القراعة التي يتم فرضها ترتكز على النص محل التفسير، إلا أن الرئيس الإداري بتلك

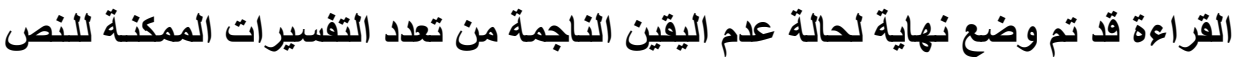
والتي كاتت تعد قبل أن يتم حسم مفهومه ـ بذلك التفسير - جميعها مشروعة، مما يعني أنه يتعين النظر إلى التفسير الذي يتم فرضه على أنه يعد منشئ لقاعدة شبه جديدة يتمثل موضوعها في تحديد مضمون قاعدة موجودة سلفاً، وبمـا أنها تفسير آمر فإنهـ سيعد بمثابة عمل قاعدي Une norme ، ذلك أنه يحدد بصورة آمرة مـا ينبغي أن يكون Sollen أو Devoir-être، وهو ما يفرض بالتالي قبول الطعن ضده بالإلغاء (").

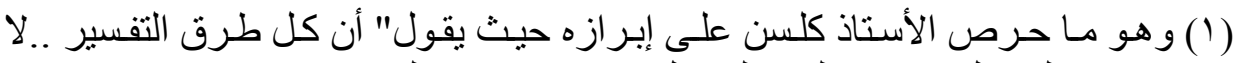

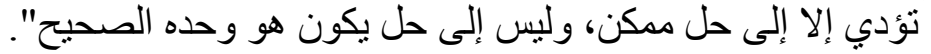

"Toutes les méthodes d'interprétation (. . .) ne conduisent jamais qu'à une solution possible, non à une solution qui soit la seule correcte.".

Kelsen H., Théorie pure du droit, ed. Dalloz, 1962.

$$
\text { مشار إليه في: }
$$

Arroudj C., De la fonction ministérielle, Thèse de l'Université de Lyon 2, 2007, p. 354..

$$
\text { (r) وقد دافع عن هذا الاتجاه عدد من الفقهاء يمكن أن نذكر منهم: }
$$

Seiller B., Circulaires et légalité, note sous Conseil d'Etat, 27 mars 1996, M. Lome, op.cit, p. 1218; Acte administratif, I-Identification, Rép. cont. adm. Dalloz, janvier 2010, p.33, $n^{\circ} 223$ et s; Petit J., Les circulaires impératives sont des actes faisant grief, op.cit, $p .510$.

$$
\text { مجلت البحوث القانونيت والإقتصاديت }
$$


وهـو مـا دافع عنـه بعض مفوضسي الحكومـة لتقريـر الخاصية التفسيرية أو

اللانحية للمنثور، ففي تقريره المقدم في قضية Marchand ذهب مفوض الحكومـة فورنيه Fournier إلى أن "مـن بين المنشورات التي يوجهها الرؤسـاء الإداريين لمرؤوسيهم فإن هناك تقسيم يجب إجراؤه بين تلكك التي تتضمن قرارات حقيقة يحتج بها في مواجهة المتعاملين مع جهة الإدارة، وتلكت التي تكتفي بمجرد إعطاء توجيهات أو توصيات، العنصر الأساسي الأي يجب إذخاله في الاعتبار في هذا التقسيم دون شكت

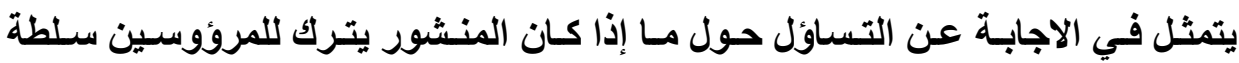
تقديرية أم لا يترك لهم تلك السلطة، وهو ما يظهر غالباً من خلال قراءة النص، وفقاً

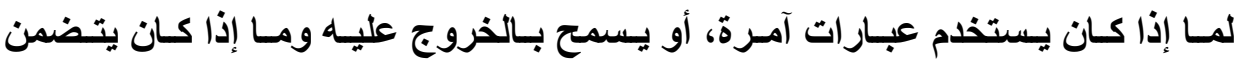

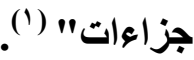

وبعيداً عن هذا التحليل وفي خـارج نطاق المنشورات نجد أن مجلس الاولة

الفرنسي قبل الطعن بتجاوز السلطة ضد بعض الأعمال الانفرادية الآمرة رغم أنسه من فئل

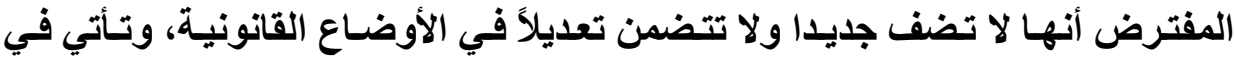

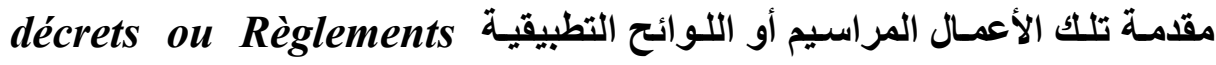

(1)"Parmi les circulaires que les supérieurs hiérarchiques adressent à leurs subordonnés un partage doit (...) être fait entre celles qui contiennent une véritable décision, applicable et opposable aux administrés, et celles qui se bornent a donner des directives ou à exprimer des recommandations. L'élément essentiel à prendre en considération pour procéder à ce partage est sans aucun doute la question de savoir si la circulaire laisse ou non subsister, chez les subordonnés, un pouvoir d'appréciation. Cela apparaîtra le plus souvent à la lecture du texte, selon qu'il emploie des termes plus ou moins impératifs, qu'il autorise ou non des exceptions, qu'il prévoit ou non des sanctions".

FournierJ., Concl. sur CE, 2 déc. 1966, Sieur Marchand, Rec., p. 562.

$$
\text { 1.V مجلتً البحوث القانونيتوالإقتصاديت }
$$


Règlements pour أو تلك التي تصدر بغرض تنفيذ القوانين d'application

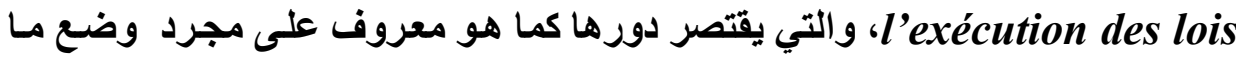
هو لازم لتنفيذ القوانين، فليس لها أن تضيف إلى هذه الأخيرة أحكاماً جديدة أو أن تحد

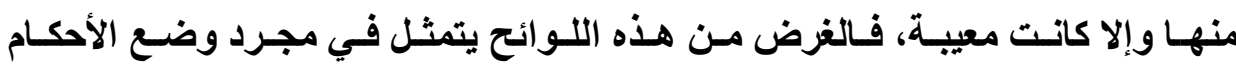

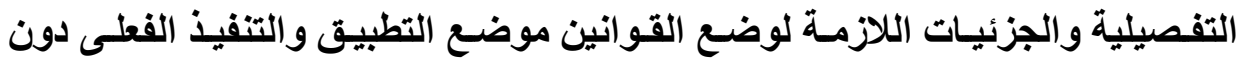

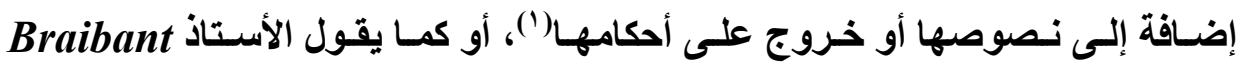

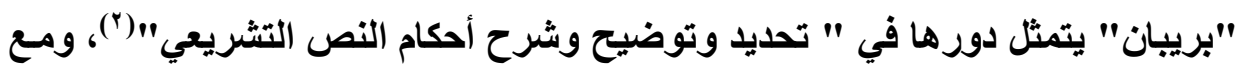
ذللك فقد قبل المجلس دائماً الطعن ضدها بالإلغاء وذلك بالنظر إلى طبيعتها اللائحية)(")،

( ) في هذا المعنى راجـع: د. سليمان الطماوي، النظريـة العامـة للقرار ات الإداريـة، الطبعة

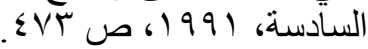

(2)"préciser, clarifier, expliciter les dispositions d'un texte législatif " Braibant G., Concl. sur CE, Sect., 12 mars 1965, Fédération des chambres syndicales des négociants importateurs de la métallurgie et de la mécanique, JCP 1966, II, $n^{\circ} 14771$.

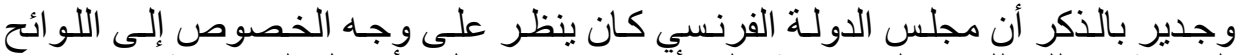

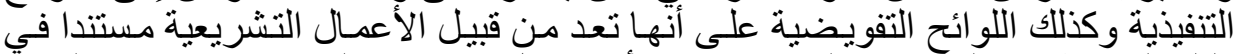

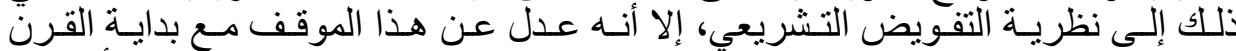

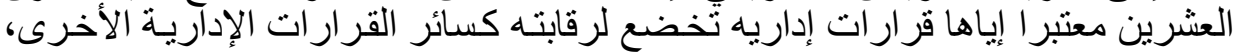

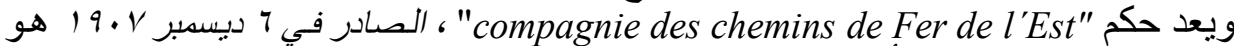
فاتحة قضائه في هذا الثأن:

CE 6 déc. 1907, compagnie des chemins de Fer de l'Est et autres, Rec. p.913,concl. Tardieu ،

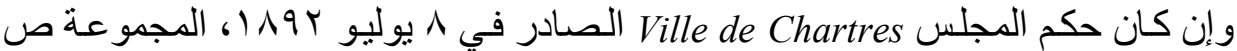

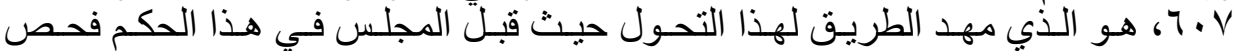

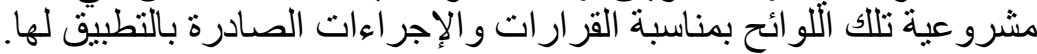

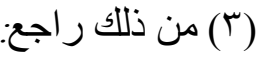

CE Sect., 12 mars 1965, Fédération des chambres syndicales de négociants importateurs de la métallurgie et de la mécanique, Rec., $p$. 165 ; JCP 1966.II.14771, concl. Braibant" ; CE Sect., 26 avr. 1978, =

$$
\text { مجلت البحوث القانونيت والإقتصاديت 1. }
$$


رغم أنـه مـن حيـث المضسمون لا يوجــ اختلاف في الحقيقة بـين مـا تتضمنه وبـين المنشورات التي تفسر بطريقة آمرة القواعد التثريعية واللائحية النافذة ، وهو ما دافع التع

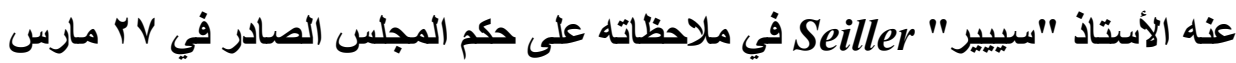
49 99 فـي قضية "Lome" (')، حيـث تـساءل: لمــاذا يحتفظ فقط بوصـف القـرار للمنشورات المعدلة aux seules circulaires modificatrices، لمساذا نرفض إضفاء هذا الوصف عندما يكتف المنشور بمجرد التعليق على النصوص النافذة؟ ألا يؤثر في هذه الحالة في الأوضاع القانونية ؟ وقد أجاب عن ذلتك بقوله بأنـه أصبح من المقبول اليوم الاعتراف بأن القرار الإداري يمكن أن يوجد دون أن يكون موضوعه الهونه يتمثل في تعديلـ سـواء بالإضـافة أو الحذف ـ في الأوضـاع القانونيـة، فهو يمكن ألا

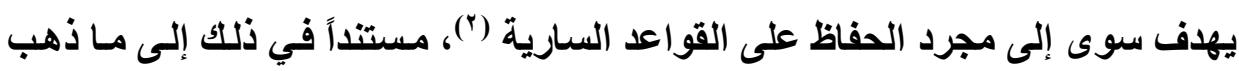
إليه الأستاذ "ديلفولفيه" Delvolvé في مؤلقه "العمل الإداري" حيث أكد على " أن العمل يمكن أن يمس أو يؤثر في الوضع القانوني بطريقتين أو بأسلوبين: بتعديله من

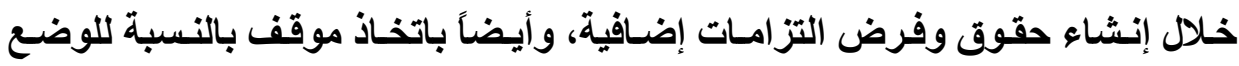
القـانوني القـائم أي بالنـسبة للحقـوق والالتزامـات التـي يتـضـنها، دون إضــافة أو

=Comité d'entreprise de la société nationale de télévision en couleur " Antenne 2 », Rec., p. 186 ; AJDA 1978, p. 502, concl. Massot ; D. 1979, p. 308, note F. Chevallier; Dr. soc. 1979, p. 43, note J.-Y. Plouvin.

Seiller B., Circulaires et légalité, note sous Conseil d'Etat, 27 mars 1996, M. Lome, , op.cit., p. 1218.

(1) Seiller B., Circulaires et légalité, op.cit.

(2)" il est aujourd'hui admis qu'une décision administrative existe sans que son objet soit une modification, par addition ou soustraction, de l'ordonnancement juridique. Elle peut ne viser qu'au maintien en l'état des règles en vigueur".

Seiller B., Circulaires et légalité, op.cit., p. 1221.

$$
\text { مجلت البحوث القانونيت والإقتصاديت } 9 \text { ه } 1 \text {. }
$$


حذف"(')، ولعل فكرة القرارات الصادرة بـالرفض تجسد ذلك المنطق، ذلك أن الوضع

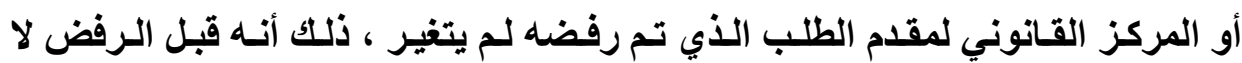
يستطيع ممارسة النشاط وهو نفس الوضع بعد أن تم رفض طلبه، بعبارة أخرى فإنـه

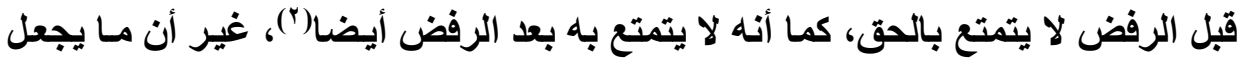

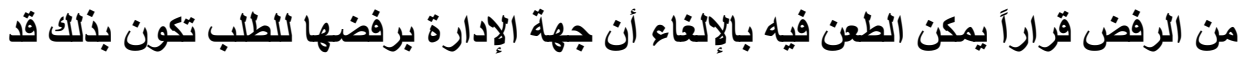

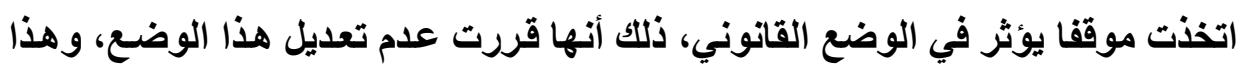
الرفض يفرض على مقدم الطلب(")

كيف يمكن إذن وفقاً لتحليل الأستاذ "سيبير" Seiller تفسير اختلاف المعاملة

القانونيـة والقضائية بين المرسـوم التفسيري أو التطبيقي والمنشور التفسيري، هل

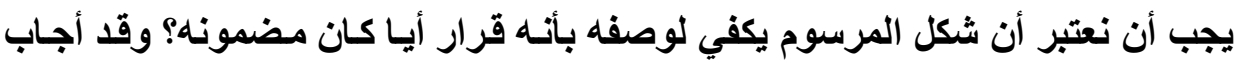

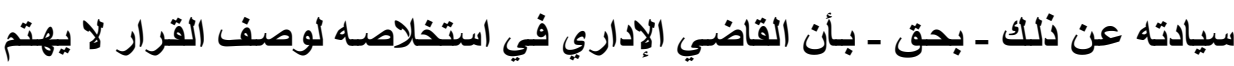

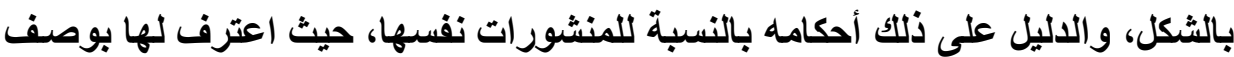
القرار القابل للطعن عندما تحمل الطابع اللائحي، ومن ثم فإن الاجابة يجب البحث عنه دها بعيداً عن فكرة الشكل، وقد حـاول الأستاذ جـان شيفالييه Chevallier في رسـالته

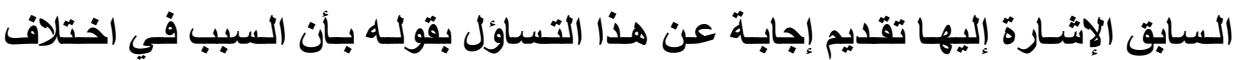

(1)" Un acte peut affecter l'ordonnancement juridique de deux manières : en le modifiant(...) par la création de droits et obligations supplémentaires ; également par une prise de position sur l'ordonnancement existant et donc sur les droits et obligations qu'il comporte, mais sans pour autant y ajouter ou y retrancher".

Delvolvé P., L'acte administratif, Sirey, 1983, $n^{\circ} 28$.

Vedel, op.cit., p. 247; Chapus R., Droit administratif, op.cit., p. 447; : راجع) Seiller B., Acte administratif, I - Identification, Rép. cont. adm. Dalloz ,janvier 2010, p.33, $n^{\circ} 241$ et $s$

(3) Seiller B., Acte administratif, I - Identification, Ibid.

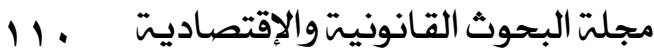


المعاملة إنما يرجع إلى أن " صيغة (المراسيم التفسيرية أو التتفيذيـة) ومـا تتمتع بـه من رسميات في إصدارها، يفترض أنها تحتوي على أحكام آمرة، فليس إلا على سبل

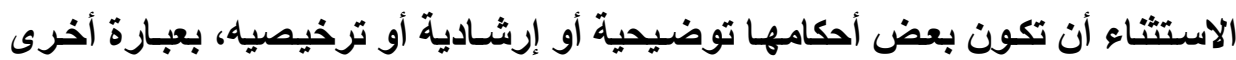

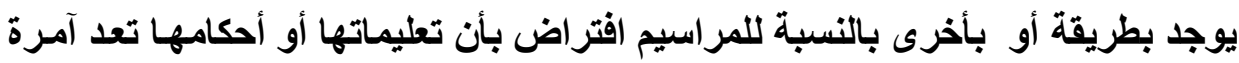

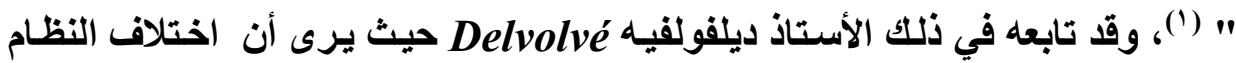

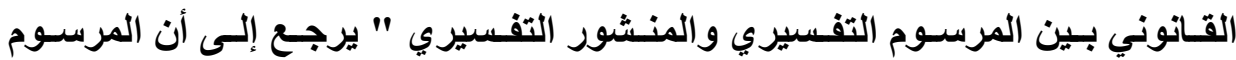
التفسيري والذي لا يفعل سوى مجرد التذكير أو توضيح نطاق الوضع القـانوني القائم يتضمن أمر بشأن تنفيذه، في حين أن المنشور والذي يكتفي بالتذكير أو توضيح التظيم القائم لا يتضمن ذلك الجزء الآمر ويعد هذا في تقديره " التفسير الوحيد الذي انئي يسمح بتبرير قبول الطعن ضد المرسوم التفسيري عكس المنشور التفسيري"((").

(1)" Par leurs formules mêmes et une certaine solennité qu'ils revêtent, apparaissent destinés à contenir, avant tout, des prescriptions impératives. Ce n'est qu'à titre exceptionnel que certaines de leurs dispositions peuvent être considérées comme simplement indicatives ou permissives. En d'autres termes, il existe en quelque sorte, pour ces actes, une présomption de prescriptions impératives".

Chevallier J.-J., L'instruction de service et le recours pour excès de pouvoir, op.cit, p. 274.

(2)"le décret qui ne fait que rappeler ou développer l'ordonnancement existant, comporte une prescription relative à la mise en ouvre de celui-ci, alors que la circulaire qui se borne à rappeler ou développer l'ordonnancement existant ne comporte pas la part de commandement déterminant sa mise en ouvre". =

"C'est en tout cas la seule explication qui permette de justifier que le décret interprétatif soit susceptible d'être attaqué devant le juge alors que la circulaire interprétative ne l'est pas ".

Delvolvé P., op. cit., $n^{\circ} 35$.

مجلة البحوث القانونيتوالإقتصاديت 111 
وقد أيد الأستاذ سيييير Seiller هذا التحليل حيث يري بأنه يبرر لمـاذا يتم

الاعتراف من جانب القاضي للمرسوم التفسيري أو التطبيقي بوصف القرار، فهو وإن commenter les textes كان لا يعدو أن يكون مجرد تعليق على النصوص السارية en vigueur الأي يتضمنه، ومن هنا كان من الضروري قبول الطعن ضده، فإذا كان التفسير صحيح فإن هذا لا يزيل أو يسحب عنه وصف القرار، ولكن فقط يسمح بـالحكم بمشروعيته

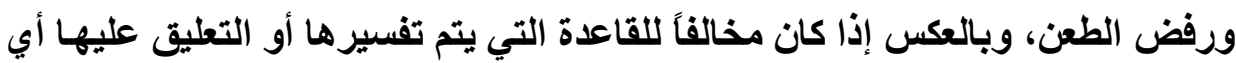

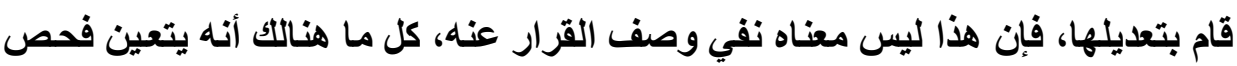
ما إذا كاتت التعديلات التي يفرضها تدخل في نطاق سلطة مصدره من عدمها. وانطلاقًاً مما تقدم فقد انتهى الأستاذ "سيبير " Seiller إلى أن ما ينطبق على المراسيم التفسيرية أو التنفيذية يجب أن ينطبق أيضاً بالنسبة للمنشورات، فبإذا كـان القاضي الإداري يعتد في المقام الأول بشأن قبول الطعن بالطبيعة الآمرة للمرسوم، فإنـه لـانه

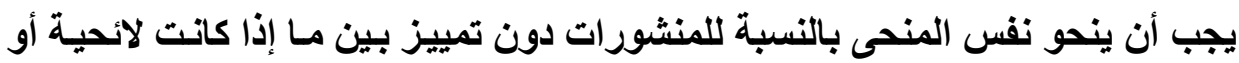

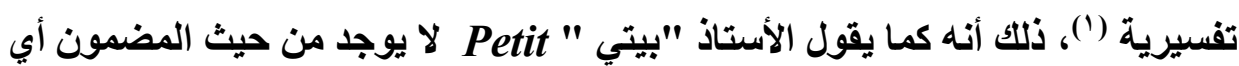

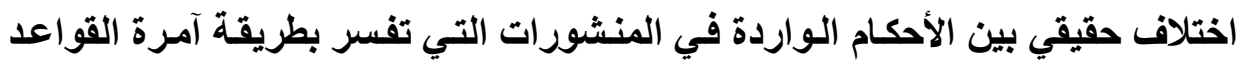

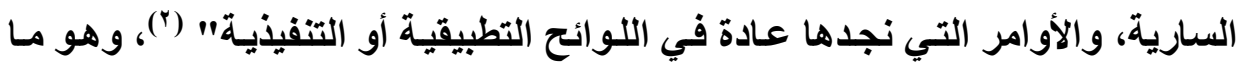

( ) و وذا في تقديره ما يفعله القاضي غالبا عندما يقرر رفض الطب الطبيعة اللانحية للمنشور وذللك بالنظر إلى كونه لا يعدو أن يكون مجرد مقنرحات النيات أو توصيات.

Seiller B., Circulaires et légalité, op.cit., p. 1221.

(2)" Au point de vue de leur contenu, il n'y a, en réalité, aucune différence entre les dispositions contenues dans les circulaires qui interprètent, de manière impérative, les règles en vigueur et les prescriptions que l'on trouve communément dans des règlements d'application".

Petit J., Les circulaires impératives sont des actes faisant grief, op.cit, p.510

مجلت البحوث القانونيت والإقتصاديت 
اسـتنتجه أيـاً الأسـتاذ "دوانسس" Douence في رسـالته حول السلطة اللائحيـة للإدارة حيث ذهب إلى أن " التطبيق الكامل للنظرية العامة للأعمال الإدارية كـان ينبغي

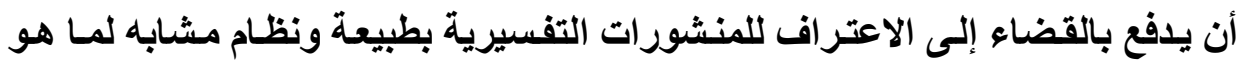

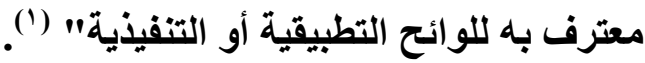

وقد يقال بأن رفض القاضي الطعن المباشر في المنشورات التفسيرية إنما يرجع إلى أنه اعتبر بأن الرفض في هذه الحالة لن يصيب المتعاملين مـع جهة الإدارة بأية أضرار، ذلك أنه يمكنهم بمناسبة الطعن في القرارات الصادرة تطبيقاً لتلك المنشورات الدفع بعدم مشروعيتها، بحيث إذا ثبت عدم مشروعيتها فإن هذا العيب يلحق بدوره القرار المستتـ إليها، غير أن هذه الحجـة تعد في الواقع غير مقتعة ذلكك أن الطعن L'exception في المباشر Le recours direct لا يؤديان في الحقيقة إلى نفس النتيجة ذلك أن الطعن المباشر من شأنه d'illégalité وضـع نهايـة وبأثر رجعي للمنشور، أمسا الدفع بعدم المشروعية فـلا يؤدي سوى إلى الامتناع عن تطبيقه في القضية المعروضة مع بقائه ساريا(؟).

(2)"L'application complète de la théorie générale des actes administratifs [aurait dî] logiquement conduire la jurisprudence à reconnaître aux circulaires interprétatives une nature et un régime comparable à ceux d'un règlement d'application ."

Douence J.C., Recherches sur le pouvoir réglementaire de l'administration, LGDJ,1969, p. 320.

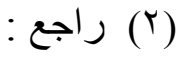

Petit J., Les circulaires impératives sont des actes faisant grief, op.cit.

$$
\text { لمزيد من التفاصيل بشأن الافع بعدم المشروعية راجع: }
$$

De Laubadère, Traité de droit administrative, Op.cit, p.535;Chapus R.,. Droit administratif , op.cit, p. 706 et p. 890; Seiller B., L'exception d'illégalité des actes administratifs, thèse, Paris II, 1995.

مجلتة البحوث القانونيت والإقتصاديت ب 11 


\section{المبحث الثاني}

\section{الاعتماد على الطبيعة الآهرة للمنشهور كمعيار \\ لقبول الطعن بالإلغاء}

أمام الصعوبات التي واجهت المجلس في تطبيقه للمعيار المستمد من مضمون

المنشور "معيار الإضافة أو الاستحداث"، وإدراكاً مـن جانبه أن حمايـة المتعـاملين مـع جهة الإدارة تستوجب التوسع في قبول الطعن بتجاوز السلطة ضد المنشورات وعدم التشدد في إضفاء الطابع اللائحي عليها، حتى يتسنى فحص مشروعيتها دون انتظار معاناة الأفراد جراء تطبيقها عليهم، أي دون انتظار معاناة أضراره في عدد من الحالات

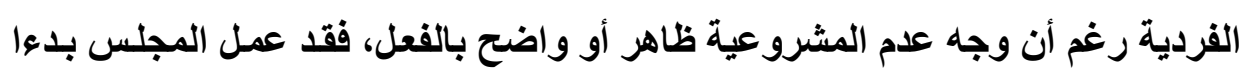

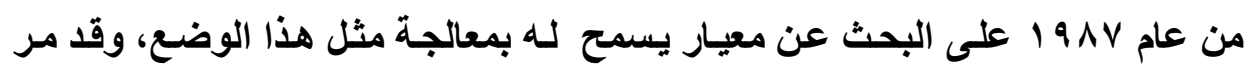
قضاء المجلس في هذا الخصوص بمرحلتين: الأولى: وتعد في الحقيقة امتدادا لقضاء

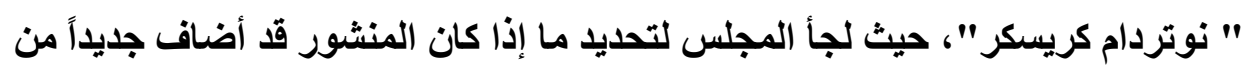

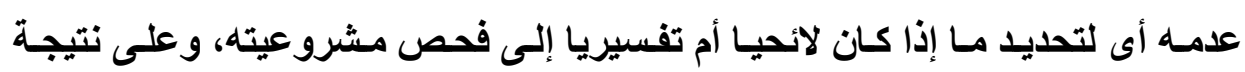

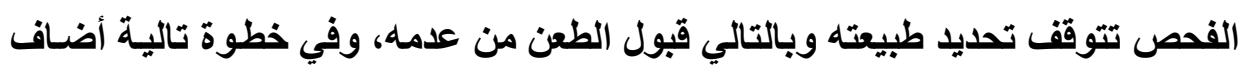
إلى المشروعية الطبيعة الآمرة للمنشور، ويطلق الفقه على المعيار الذي تبناه المجلس في تلك المرحلة معيار المشروعية La légalité " المطلب الأول "، المرحلة الثانية: وتبدأ عام r . . ب بصدور حكم المجلس في قضية دوفينيير Duvignières، والتي اكتفى فيها مجلس الدولة الفرنسي لقبول الطعن بتجـاوز السلطة ضد المنشورات بأن تكون ذات طبيعة آمرة caractère impératif،" المطلب الثاني ". 


\section{المطاب الأول}

\section{التمهيد المعيار الطبيعة الآهرة}

\section{"المشروعية هعيار الطبيعة التفسيرية للمنشور"}

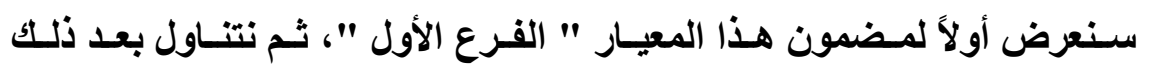

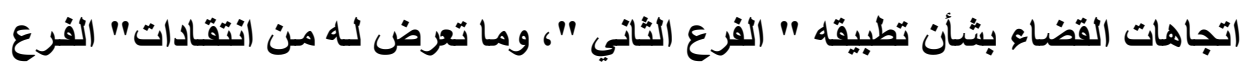

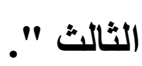

\section{الفرع الأول \\ هضمون هميار المشرووية}

قدمنا بأنه أمام الصعوبات التي واجهت المجلس في تطبيقه للمعيار المستمد من مضمون المنشور، واقتناعا من جانبه بأن حماية المتعاملين مع جهة الإدارة تستوجب التوسع في قبول الطعن بتجاوز السلطة ضد المنشورات وعدم التشدد في إضفاء الطابع اللائحي عليها، حنى يتسنى فحص مشروعيتها دون انتظار معانـاة أضرارها في عدد

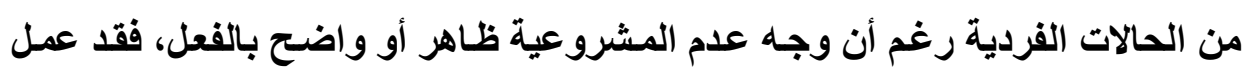
ابتـاء مـن عـام 9 1 ل على جعل المشروعية هـي المعيـار المحدد لطبيعة المنشور التفسيرية أو اللائحية، أي المحدد لقبول الطعن بالإلغاء ضد المنشور من عدمه، بعبارة

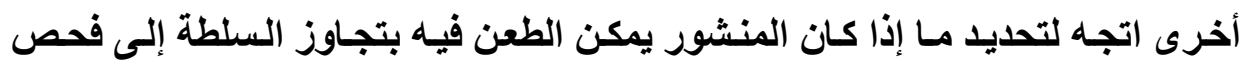
مشروعيته، وعلى نتيجة الفحص تتحدد طبيعته، فإذا كـان مشروعاً Légal أي مطابقا

مجلت البحوث القانونيت والإقتصاديت 11 مجر 11 
للقانون، فإنـه يعد في نظره تفسيرياً ومـن ثم لا يقبل الطعن ضده، أمسا إذا كـان غير مشروع Illégal فإنها يعد لائحياً ومـن ثم يقبل الطعن ضده بتجـاوز السلطة ويتعين إلغاؤه إذا ثبت بطبيعة الحسال أن مصدره غير مختص، وقد برز هذا الاتجـاه بصورة واضحة في حكم "نقابة المحامين لدى محكمة بـاريس" Ordre des avocats à la ( الصادر في 10 Cour de Paris

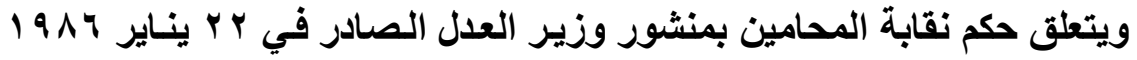

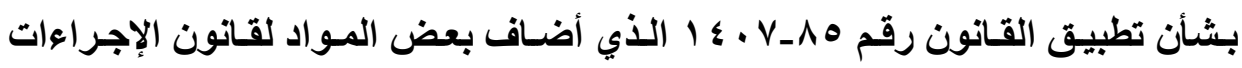

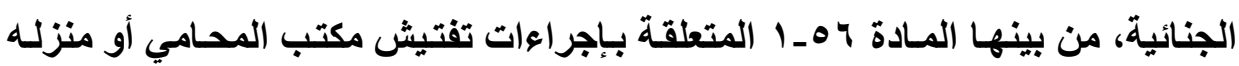
والتي تقضي بأنه " تفتيش مكتب المحامي أو منزله لا يمكن أن يتم إلا من قبل قاض وبحضور نقيب المحامين أو من ينوب عنه "(").

travaux يـ اعتبر المجلس، بعد الرجوع للأعمـال التحضيرية للقـانون préparatoire ، أن الأحكام الواردة في منشور وزير العدل المتعلقة بتطبيق تلك المادة لا تعدو مجرد تفسير للنصune simple interprétation ، وذلك نظراً لعدم

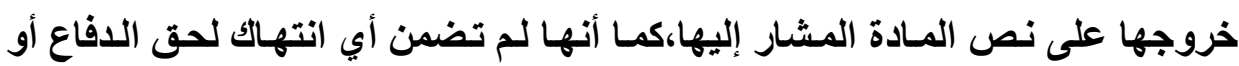
احترام السر المهني، فضلا عن عدم تعارضهـا مـع قواعد القانون الدولي التي تتمتع

(1) CE 15 mai 1987, Ordre des avocats à la Cour de Paris, Rec. p. 175 ; RFDA 1988, p. 146, concl. Marimbert J.

$$
\text { (r) ويجري نصها باللغة الفرنسية على النحو التالي: }
$$

"Les perquisitions dans le cabinet d'un avocat ou à son domicile ne peuvent être effectuées que par un magistrat et en présence du bâtonnier ou de son délégué". 
بقوة القانون على الإقليم الفرنسي، وبناء عليه رفض قبول الطعن بتجـاوز السلطة ضد هذا المنشور (1).

والواقع فإن التمعن فيما انتهى إليه المجلس في هذا الحكم يظهر بأنه لا يعدو في

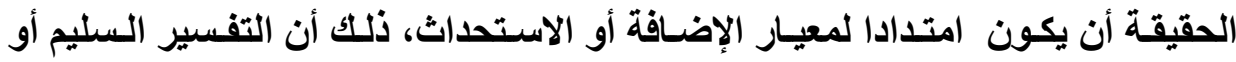

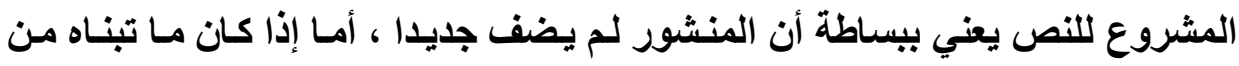
تفسير يعد مخالفاً للنص فِإن هذا معنـاه أنـه أضـاف جديداً ومن ثم سيعد ذات طبيعة لائحية بحيث يصبح من المقبول الطعن ضده بتجاوز السلطة، سواء قمنا بتطبيق معيار الإضافة أو معيار المشروعية.

(1)"que les dispositions critiquées de la circulaire..ne comportent aucune violation de l'article 56-1 du nouveau code de procédure pénale et ne portent atteinte ni aux droits de la défense, ni au respect du secret professionnel.. que ces dispositions ne contredisent par ailleurs pas des règles du droit international ayant force de loi sur le territoire national.. par suite, elles ne sont pas de nature à faire l'objet d'un recours pour excès de pouvoir".

$$
\text { راجع أبضاً: }
$$

CE 29 juin 1990, Groupe d'information et de soutien des travailleurs immigrés (GISTI), Rec. p. 171, concl. Abraham R., AJDA 1990, p. 621, note Teboul G. et concl. Abraham. R.; RFDA 1990, p. 923, note Lachaume J.,

ويتعلق بمنشور مشترك صسادر من وزيري الداخلية والشئون الاجتماعية بشأن تفسير الاتفاق

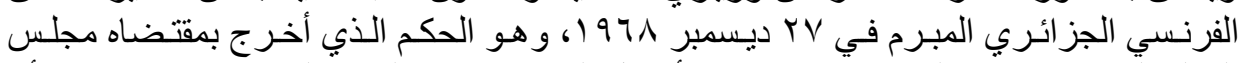

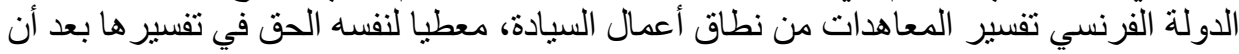

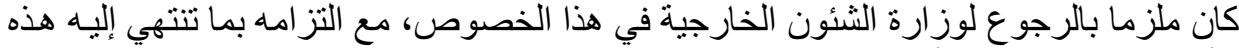

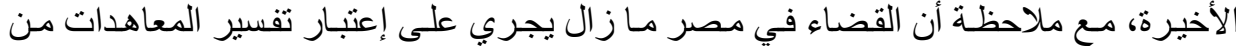
أعمال السيادة، راجع على سبيل المثالّ:

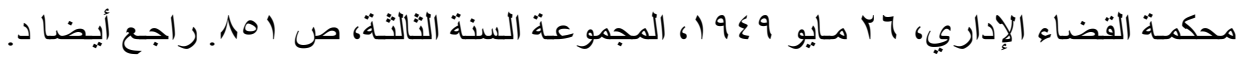

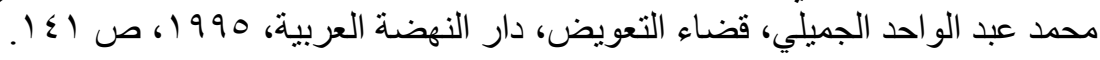


وقد عـاد المجلس في عـام به9 19 مضيفاً إلى المشروعية الصفة أو الطبيعة

الآمرة للمنشور Le caractère impératif de la circulaire ،بحيث أصبح يلزم

لقبول الطعن ضد المنشور أن يؤخذ في الحسبان الصفتين معاً ، بمعنى أنها يلزم بلايـة أن يكون المنشور ذات طبيعة آمرة أما تحديد طبيعة المنشور ومن ثم قبول الطعن ضده من عدمه فإنه يتوقف على مدى مشروعيته، بحيث إذا ثبت عدم مشروعيته فإنها سيعد ذات طابع لاتحي ومن ثم يقبل الطعن ضده ، أما إذا كان ذات طبيعة آمرة ومشروع فإنـه سيعد منشوراً تفسيرياً ومن ثم لا يقبل الطعن فيه بتجاوز السلطة. وقد ظهر هذا الاتجاه بصورة واضحة ابتداءً من حمم مجلس الدولة الصادر في 1 1 يونية ب9 19 في قضية "إفوب" IFOPI")، والتي تتلخص وقائعها في أن لجنة استطلاعات الرأي La Commission des sondages، والتي تعد إحدى السلطات Un communiqué الإدارية المستقلة، قامت في 1 ا مسارس ب 99 1 بإصدار نشرة

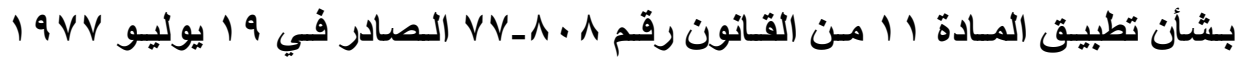
المتعلق بنشر وتوزيع بعض استطلاعات الرأي، والتي كاتت تقضي بأنه " يحظر أثناء الأسبوع الذي يسبق الانتخـاب وأثنـاء جريانـه نشر أي استطلاع للرأي أو توزيعه أو

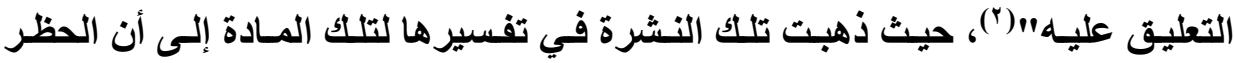

(1) CE 18 juin 1993, Institut français d'opinion publique (IFOP), Rec. $p$ 178 ; Rev. adm., p. 322, concl. Scanvic F.

(2)"Pendant la semaine qui précède chaque tour de scrutin ainsi que pendant le déroulement de celui-ci, sont interdits, par quelque moyen que ce soit, la publication, la diffusion et le commentaire de tout sondage tel que défini à l'article ler".

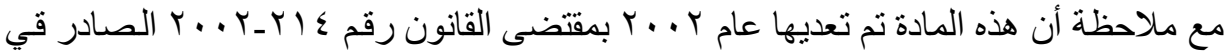

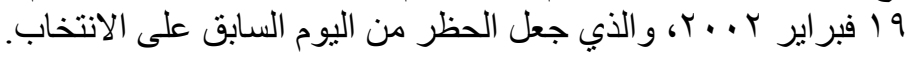

مجلة البحوث القانونيتوالإقتصاديت 9 11 19 
المنصوص عليه لا ينطبق فقط بالنسبة للاستطلاعات المتعلقة بنية التصويت، ولكن ياخل في إطاره أيضا ذلك الأي يتم عند خروج الناخبين من المقار الانتخابية لتحديد أو معرفة دوافعهم، وعندما تم الطعن في تلك النشرة، رفض المجلس قبول الطعن وذلك نظرا إلى أن ما قررتهه يـخل في إطـار الحظر المنصوص عليهه في المـادة 11 المشار إليها، مؤكدا في نفس الوقت على وجوب أخذ الصفة الآمـرة والمشروعية معـا في الحسبان عند تقرير قبول الطعن ضد التفسيرات الإدارية حيث يقول " أن التفسير الذي تعطيه السلطة الإدارية للقوانين واللوائح .. مـن خلال أحكام أو قو اعد آمرة ذات طابع عام، لا يمكن الطعن فيها مباشرة بتجـاوز السلطة إلا إذا كانت تخـالف معنى ومضمون الأحكام التشريعية واللاتحية التى تتولى شرحها أو كاتت تخـالف المتطلبـات الداخلية لتدرج القواعد القانونية" (1)

(1)"l'interprétation donnée par l'autorité administrative des lois et règlements .. au moyen de dispositions impératives à caractère général, n'est susceptible d'être directement déférée au juge de l'excès de pouvoir que si et dans la mesure où ladite interprétation méconnaît le sens et la portée des prescriptions législatives et réglementaires qu'elle se propose d'expliciter ou contrevient aux exigences inhérentes à la hiérarchie des normes juridiques".

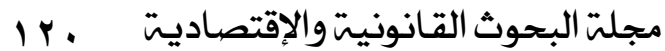




\section{الفرع الثاني \\ انقسام القضاء بشأن تطبيق معيار المشروعية}

رغم وضوح حكم "إفوب" IFOP السابق الاشسارة إليه بشأن مسألة تقدير

المشروعية حيث قرر صراحة كما رأينا بأن تفحص مشروعية المنشور لتحديد طبيعته

اللائحية أو التفسيرية ومن ثم قبول الطعن من عدمه يجب ألا يقف عند حد النص الذي مئي

يتم تفسيره، وإنما يجب أن يتم في ضوء كافة القواعد القانونية السارية مـع مراعاة التدرج بينها، إلا أن أحكام المجلس التالية انقسمت إلى اتجـاهين: الأول: رافض لهذا القضاء " أولاً "، أما الثاني: مؤيد له " ثانياً "(1)، إلى أن تم توحيد الاتجاهات في عام

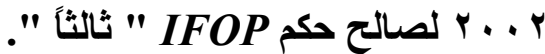

أولاً: الوقوف في فحص المشروعية عند النص الذي يتم تفسيره

تأثراً بفكرة أو معيـار الاستحداث أو الإضـافة فقد ذهبت بعض الأحكام إلى أن

العبرة عند تفحص مشروعية المنشور هي بالنص الذي يتولى المنشور تفسيره بغض النظر عن مشروعية هذا النص أو عدم مشروعيته، بحيث إذا ثبت بـأن المنشور قام بدقة أو بأمانة بتفسير هذا النص فإنه يعد مشروع أي ذات طبيعة تفسيرية ذلك أنه لـ يضف جديدا أو لم يتضمن تعديلا في الأوضاع القانونية، وبالتـالي لا يقبل الطعن ضده بتجاوز السلطة حتى وإن كـان النص الذي تم تفسيره غير مشروع لمخالفته لقاعدة

$$
\text { (1) في عرض هذين الاتجاهين راجع: }
$$

Fombeur P., Concl. sur CE, Sect., 18 déc. 2002, Duvignères, op.cit; Long $M$. et autres, Les grands arrêts de la jurisprudence administrative, 17e édition, Sirey, 2009,p. 848; Petit J., Les circulaires impératives sont des actes faisant grief, op.cit, p.510 .

مجلتة البحوث القانونيت والإقتصاديت 
أعلى في إطار تلدرج القواعد القانونية، فعدم المشروعية التي تلحق بالنص المفسر وفقـا لهذا الاتجـاه يجب أن لا تنسحب إلى المنشور ليتحول بنـاء عليها وفقا لمعيار المشروعية إلى أن يكون ذات طابع لانحي يقبل الطعن ضده بتجاوز السلطة، أو بتعبير

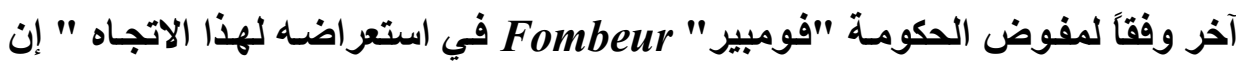
الظرف الذي يجعل النص المفسر غير مشروع ليس من شـأنه إضفاء الطابع اللانحي

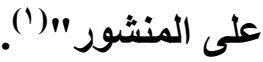

وقد يقال دفاعا عن هذا الاتجاه بأنه إذا كان النص اللانحي الذي يتولى المنشور تفسيره غير مشروع، فإنـه مـن الأفضل أن يطلب صـاحب الشـأن مـن جهـة الإدارة

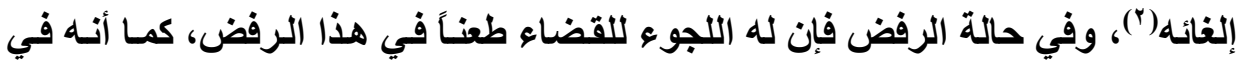

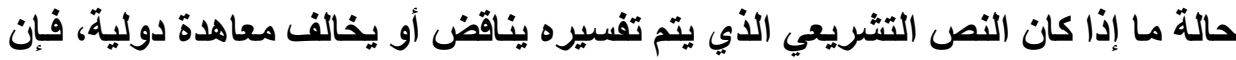

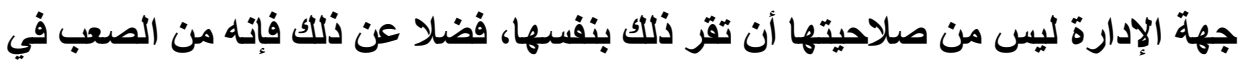

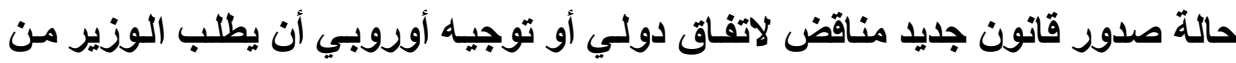

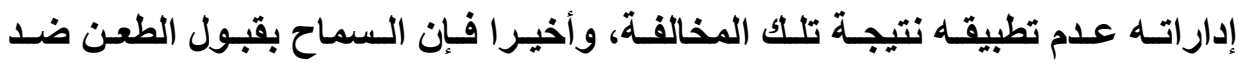

( ')"La circonstance que le texte interprété par la circulaire serait illégal n'est pas de nature à conférer un caractère réglementaire à la circulaire.". Fombeur P., Concl. sur CE, Sect., 18 déc. 2002, Duvignères, op.cit, p. 280.

$$
\text { ومن تطبيقات المجلس لهذا الاتجاه راجع: }
$$

CE, 15 avr. 1996, Union des industries chimiques, Rec., tables, p. 666 ;27 mai 1998, Groupe d'information et de soutien des travailleurs immigrés, Rec., tables, p. 674;- .CE, 6 mai 1996, Entreprise à responsabilité limitée du domaine d'Albareto, Rec., tables, p. 666;- CE, 8 juill. 1998, Fédération française des spiritueux, Rec. p. 299.

$$
\text { (T) راجع فيما سبق، ص (9 هامش، ص } 9 \text { (T) }
$$


المنشورات التي تفسر بلدة نصا تثريعيا غير مشروع معناه السماح للأفراد بالطعن في القوانين من خلال الطعن في المنشورات(') ثانياً : عدم الوقوف في فحص المشروعية عند النص الذي يتم تفسيره على خـلاف الاتجـاه الأول والـذي يبدو أنـهـ ظل متــأثرا بمعيـار الاسـتحداث أو الإضافة في إطار النص الذي يتم تقسيره، فإن هذا الاتجاه فضل السير قدماً في الاتجاه الذي أعلنه حكم "إفوب" IFOP ، ومـن ثم فإنـه يتعين عنــ الحكم على مشروعية المنشور لتقرير ما إذا كان تفسيريا أو لائحيا عدم الوقوف عند النص الذي يتم تفسيره، و إنما يجب النظر إلى ما إذا كان هذا النص يخالف قاعدة أعلى من عدمه بحيث إذا ثبتت لإن تلك المخالفة فإنها تنسحب إلى المنشور حيث يصبح بدوره غير مشروع بغض النظر عن التزامه أو عدم التزامه حدود النص الذي يتولى تفسيره أي حتى ولو ثبت بأنسه لـ لـ يفعل سوى مجرد ترديد الحكم الوارد في النص الذي يتم تفسيره دون أدنى إضـافة أو

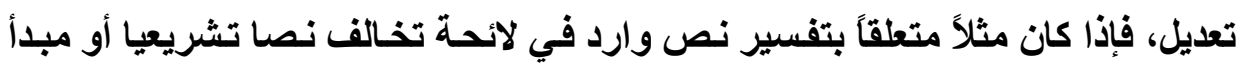
قانوني عام، أو بتفسير نص تثريعي يناقض معاهدة دولية تم التصديق عليها، فإنه في هذه الحالـة حتى وإن كـان قد فسر بدقـة أو بأمانـة Fidèlement النص اللائحسي أو التشريعي مما يعنى بأنه في هذا الإطار يعد مشروع ذلك أنـه لـ يضف جديدا، إلا أنـه وفقاً لقضاء إفوب IFOP سوف يعد غير مشروع لمخالفة النص اللائحي أو التشريعي الذي يتم تفسيره لقاعدة أعلى، ومن ثم يمكن قبول الطعن ضده بوصفه في هذه الحاله وفقا لمعيار المشروعية ذات طابع لائحي ().

( (1) في عرض هذه الحجج راجع تقرير مفوض الحكومـة فومبير Fombeur السابق الإشـارة إليه.

(r) ومن تطبيقات المجلس لهذا الاتجاه راجع: CE, 14 janv. 1998, Confédération française démocratique du travail, Rec. p. 2 ;- CE, Sect., 2 juin 1999, Meyet, Rec. p. 160 ; Petites affiches, = 
ثالثاً : توحيد اتجاهات مجلس الدولة بشأن تطبيق معيار المشروعية

إذا كانت هناك كما رأينا بعض الاعتبارات وقفت وراء تبني المجلس في بعض

أحكامه للاتجاه الأول، إلا أن الاتجـاه الثاني ينبع في الواقع من اعتبارات كـان لها في النهاية الظلبة في توحيد المجلس لقضائه لصالح هذا الاتجاه.

فالحكمـة في الواقع مـن قيـام السلطات الإداريـة بإصــار المنشورات لإداراتها

المختلفة تتمثل في بيـان كيفية تطبيق القـانون المكلفين بوضعه موضع التفيذ، هذا

القانون لا يقتصر في الحقيقة على النص الأي يتم تفسيره، و إنما هو عبارة عن مزيج

من جميع النصوص والمبادئ التي تنطبق أو تحكم مجـال أو موضوع معين، وهو مـا حرص مفوض الحكومة فومبير Fombeur التأكيد عليه في تقريره سالف الأكر حيث يرى بأنها يعد من قبيل الوقوف في منتصف الطريث au milieu du gué أن يتم فحص مشروعية التفسير الإداري بـالنظر فقط إلى النص الذي يتم تفسيره وتجاهل وضع هذا الأخير في التسلسل الهرمي للقواعد القانونية"(')، أى تجاهل مدى اتفاقه مع الإدي لـع القواعد الأعلى منـه، مشيراً إلى أن المجلس أكد في أكثر مـن موضع على أنى أن جهة

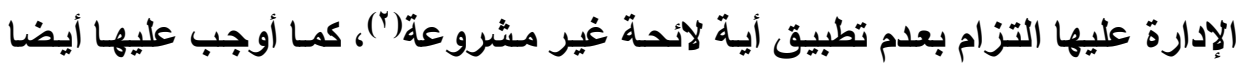
الامتنـاع عن تطبيق قانون يتعارض مـع معاهدة أو اتفـق دولـي، وإلا ستعد قراراتها

$=n^{\circ} 113,8$ juin 1999, p. 11, concl.. Bonichot J-C, AJDA 1999, p. 560, chron. Raynaud F. et Fombeur P.;- CE, 7 juin 2000, Fédération des syndicats généraux de l'éducation nationale et de la recherche publique, req. 159755 , Rec. tables.

(1)" Il nous semble que vous resteriez au milieu du gué si vous vous borniez à vérifier l'exacte interprétation d'un seul texte, en faisant abstraction de son insertion dans la hiérarchie des normes".

(2)CE, Sect., 14 nov. 1958, Ponard, Rec. p. 554 ; 8 nov. 1968, Menez, Rec. p. 557.

مجلتة البحوث القانونيت والإقتصاديت ا 
الصادرة بالتطبيق لهذا القانون غير مشروعة (')، فضلاً عن ذلك فيان الملائمة تقتضي

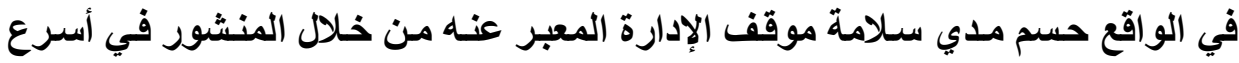
وقت ممكن تجنباً لكثرة القضايا المتعلقة بهذا الموقف، ذلك أن رفض الصفة اللانحية

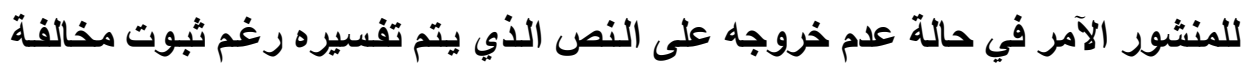

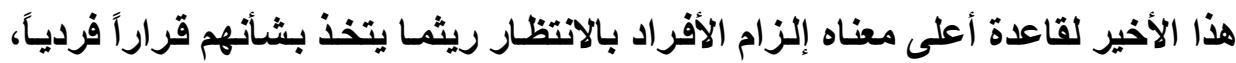

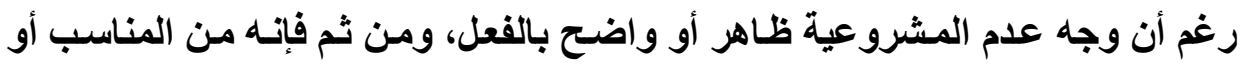

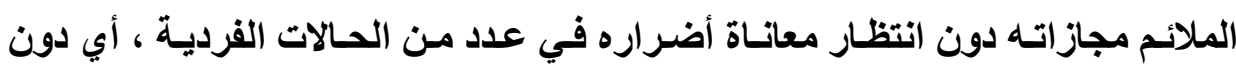
انتظار معاناة الأفراد جراء تطبيقه عليهم("). أمسام هـذه الاعتبـارات قـرر المجلـس بمقتضى حكـم الجمعيـة الـصادر فـي

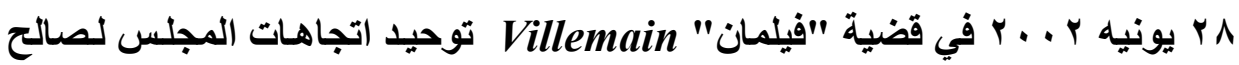
حكم " إيفوب" IFOP (") مستخدماً نفس العبارات التي استخدمها هذا الحكم وإن كان قد حرص على التثثديد على الطبيعة الآمرة للمنشور حتى يمكن الطعن فيه بتجاوز

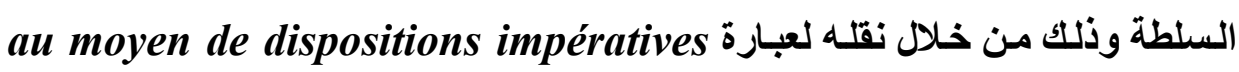

(1)CE, Ass., 28 févr. 1992, SA Rothmans International France et SA Philip Morris France, Rec. p. 81, concl. M. Laroque M Fombeur P., Concl. Sur CE, Sect., 18 déc. 2002, Duvignères ,op.cit.

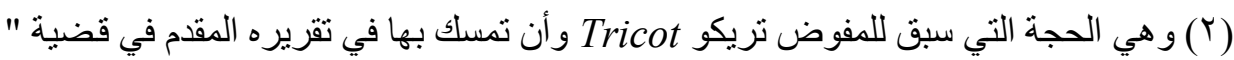

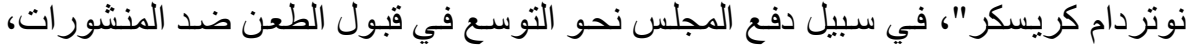

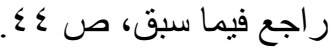

(3)CE Ass. 28 juin 2002, Villemain, RFDA 2002, p. 723, concl. Boissard S.; AJDA 2002, p. 586, chron. Donnat F. et Casas D

مجلت البحوث القانونيت والإقتصاديت ر ا 
لتصبح في مطلع الحيثية لإبراز مدى الأهمية التي يوليها لتلك الطبيعة بشأن قبول

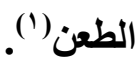

وتخلص وقائع هذه القضية في أنه بعد صدور قانون ه 1 نوفمبر 999 19 بشأن

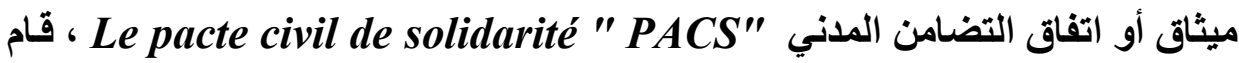

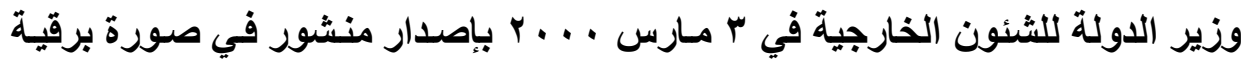

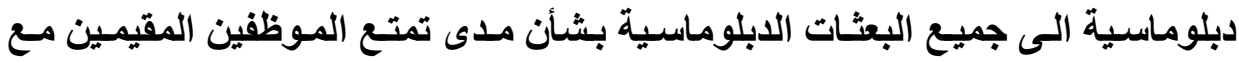

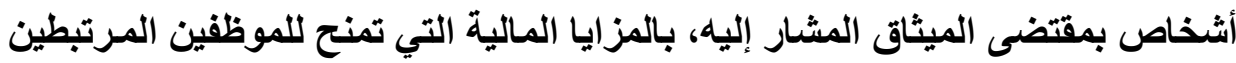

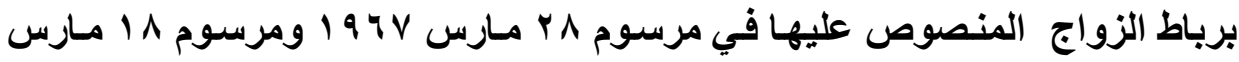

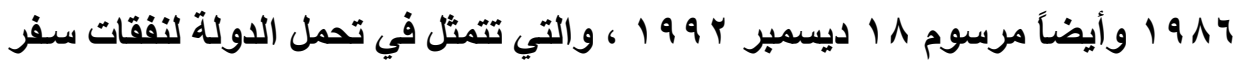

$$
\text { (1) (1) حيث تجري صياغة حكم إيفوب كما رأينا على النحو النالي: }
$$

"l'interprétation donnée par l'autorité administrative des lois et règlements qu'elle a pour mission de mettre en oeuvre, au moyen de dispositions impératives à caractère général, n'est susceptible d'être directement déférée au juge..."

$$
\text { في حين حرص المجلس في حكم فيلمان على نقل هذه العبارة إلى مقدمة الحيثية: }
$$

"l'interprétation que l'autorité administrative donne au moyen de dispositions impératives à caractère général des lois et règlements qu'elle a pour mission de mettre en oeuvre n'est susceptible d'être directement déférée au juge de l'excès de pouvoir que si et dans la mesure où cette interprétation méconnaît le sens et la portée des prescriptions législatives ou réglementaires qu'elle se propose d'expliciter ou contrevient aux exigences inhérentes à la hiérarchie des normes juridiques".

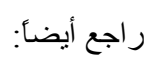

Fombeur P., Concl. sur CE, Sect., 18 déc. 2002, op.cit ;- Long M. et autres, Les grands arrêts de la jurisprudence administrative, 17e édition, Sirey, 2009, op.cit .

مجلة البحوث القانونيتوالإقتصاديت ب ا 
ونقل امتعة زوج الموظف فضلاً عن حصول هذا الأخير كنتيجة للزواج على علاوة أسرية تضاف إلى راتبه، حيث رأي الوزير بأن اتفات التضامن المدني لا يعدو أن يكون

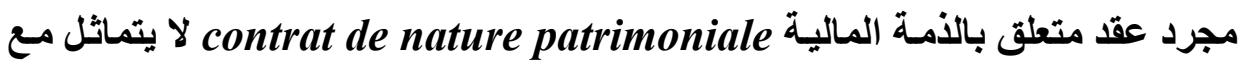

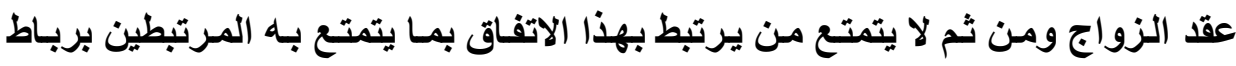

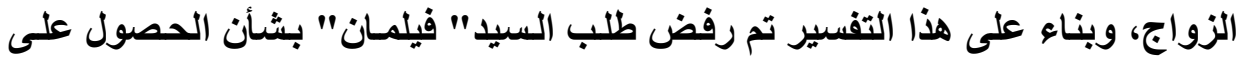

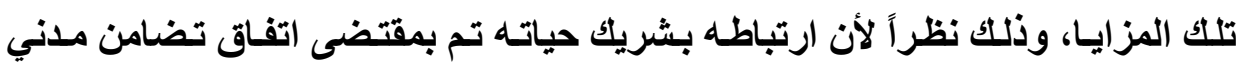

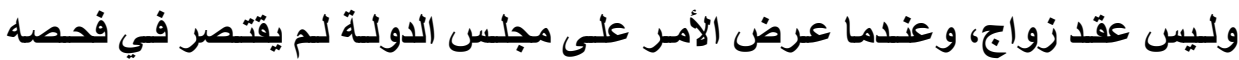

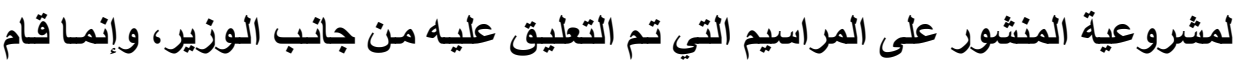
بفصه في ضوء المشروعية ككل La légalité dans son ensemble حيث لـ يقرر عدم قبول الدعوى لمشروعية ما انتهى إليه وزير الخارجية إلا بعد التحقق من أن

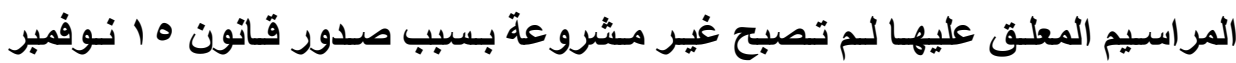
و99 99 سالف الأكر، ومن أن مـاورد في هذا المنشور لا يمثل إخلالاً بمبدأ المساواة ذلك المبدأ الذي استتد إليه السيد "فيلمان" لتبرير طعنه أيضاً بتجاوز السلطة، وفي هذأ هذأ

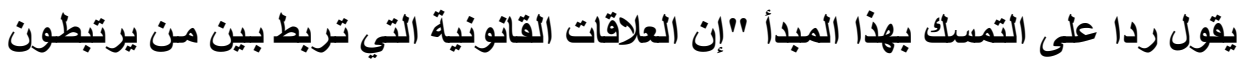
باتفاق التضامن المدني تم تنظيمها من جاتب المشرع بصورة مختلفة، وبصفة خاصـة من زاوية قوتها واستقرارها إذا ما قورنت بتلك التي توجد بين الزوجين، ومن حيث أن أن

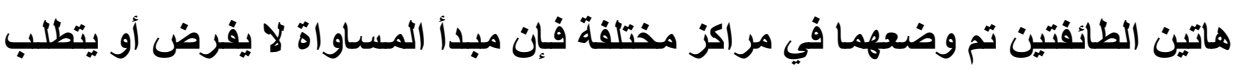

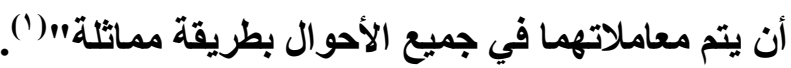

(1)" les liens juridiques qui unissent les personnes ayant conclu un pacte civil de solidarité ont été organisés par le législateur de manière différente, notamment du point de vue de leur intensité et de leurs stabilité, de ceux qui existent entre deux conjoints ; que ces deux catégories de personnes étant ainsi placées dans des situations juridiques différentes, le principe d'égalité n'impose pas qu'elles soient traitées, dans tous les cas, de manière identique». 
ولا شكك أن الاستقرار على مثل هذا الاتجاه يضع بذلك نهايـة لمعيـار الإضـافة أو

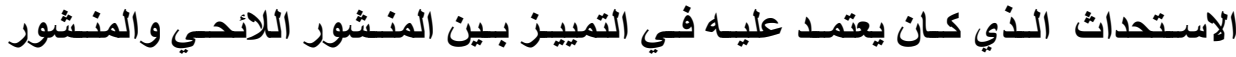
التفسيري، ذلك أن المنشور وفقاً لهذا الاتجاه تثوافر له الصفة اللائحية ومن ثم يجوز الطعن ضده حتى وإن كان لم يتضمن جديداً أي حتى وإن ثبت بأنه لم يفعل سوى مجرد ترديد الحكم الوارد في النص اللائحي أو التشريعي طالمسا أن هذا الأخير غير مشروع وكان المنشور ذات طبيعة آمرة، مما يعنى أن معيار الإضافة أو الاستحداث لم يعد يفيد بثأن قبول الطعن بتجاوز السلطة ضد المنشورات.

\section{الفرع الثالث}

\section{تقدير هميار المشروعية}

قدمنا أن الأخذ بمعيـار المشروعية وفقـا لمـا استقر عليه المجلس في قضاء "فيلمان" Villemain كمعيار محدد لطبيعة المنشور، أي كمعيار محدد لمـا إذا كـان المنشور لاتحياً يقبل الطعن فيه بتجاوز السلطة أو تفسيرياً لا يجوز الطعن ضده، يضع نهاية لمعيار الاضافة أو الاستحداث المستمد من قضاء "نوتردام كريسكر" والذي كان يعتمد في التمييز بين المنشور اللائحي والمنشور التفسيري على ما إذا كان المنشور قـ أضاف جديداً من عدمه للنص الذي يتم تفسيره، مما يعني أن الإضافة أو الاستحداث لم تعد تفيد بشأن قبول الطعن بتجـاوز السلطة ضد المنشورات، ذلك أن المنشور وفقا لقضاء "فيلمان" ومن قبله قضاء "إيفوب" كما رأينا تتوافر لـه الصفة اللائحية ومن ثم يجوز الطعن ضده حتى وإن لم يكن يتضمن جديدا أي حتى وإن ثبت بأنـه لم يفعل سوى مجرد ترديد الحكم الوارد في النص اللائحي أو التشريعي طالمسا أن هذا الأخير وفقا لقواعد التدرج يعد غير مشروع وكان المنشور ذات طبيعة آمرة. غير أن هذا المعيار وإن كان قد ظهر لمعالجـة الصعوبات التي واجهت المجلس في تطيقه لقضاء 
" " نوتردام كريسكر " " إلا أنه تعرض للنقد من جانب كل من تناول من الققه الفرنسي هذا المعيار بالدراسة والتحليل، نظراً لكونه ينبع في الحقيقة من منطق غريب أو تحليل غير منطقي، ذلك أن القاضسي بشأن قبول الطعن لا يبدأ بفحص طبيعة المنشور ولكن مشروعيته، ومن مشروعيته يقوم باستخلاص طبيعته، بحيث إذا ثبت عدم مشروعيته أي صحة ما استتد إليه الطاعن فإنـه سيعد لاتحيًا ومسن ثم تقبل دعوى تجـاوز السلطة ضده، بعبارة أخرى يتوقف قبول الدعوى وفقا لهذا المعيار على ثبوت صحة مـا يقدمـه الطاعن من أسانيد موضوعية وحجج وبراهين Le bien-fondé du recours بشأن

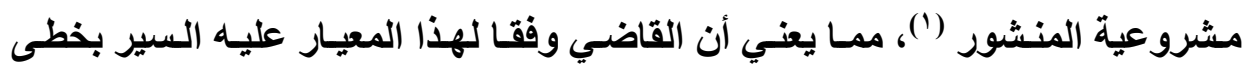
عكسية إذ أن عليه أولا التصدي لموضوع الدعوى أو المخالفة المدعاة، ثم بعد ذلك يقرر ما إذا كاتت الدعوى مقبولة من عدمه، في حين أن المستقر عليه أن الفصل في

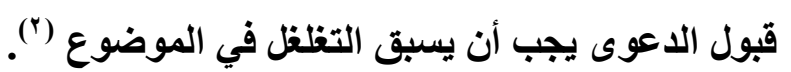

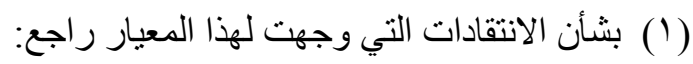

Chapus R., Droit du contentieux administratif, op.cit, p. 551; Petit J., Les circulaires impératives sont des actes faisant grief, op.cit, p.510 ; Donnat F., Les dispositions impératives à caractère général d'une circulaire ou d'une instruction font grief, AJDA 2003 p. 48, Fombeur P., Concl. sur CE, Sect., 18 déc. 2002, op.cit ;- Long M. et autres, Les grands arrêts de la jurisprudence administrative, 10e édition, Sirey, 1993,op.cit, p.514.

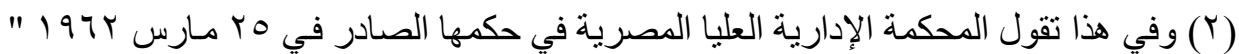

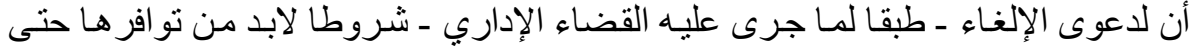

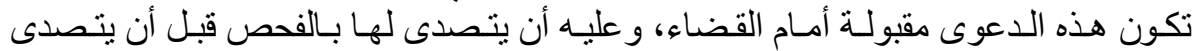

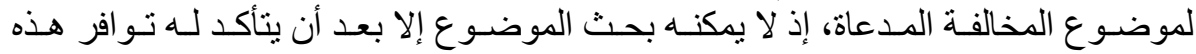

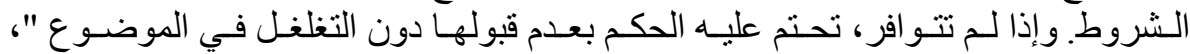

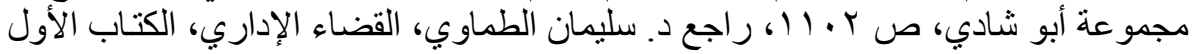

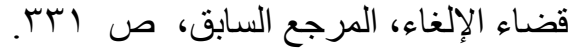




\section{الاطلب الثاني \\ الاعتهاد فتط على الطبيعة الآهرة للمنشهور كمعيار لقبول الطعن بالإلغاء}

رغم أن فكرة الطبيعة الآمرة للمنشور لقبول الطعن ضـ المنشورات لـم تكن غائبة في حكم " إيفوب" وحكم " فيلمان" السابق الاشارة إليهمـا، إلا أن المجلس في هذه الأحكام كان لا يزال بشأن قبول الطعن حبيس التفرقة بين المنشورات التفسيرية والمنشورات اللائحيـة القائمسة على فكرة الإضـافة أو الاستحداث، حيث ظل في هذه الأحكام متمسكا بعدم قبول الطعن بتجـاوز السلطة ضد المنشورات التفسيرية، صحيح

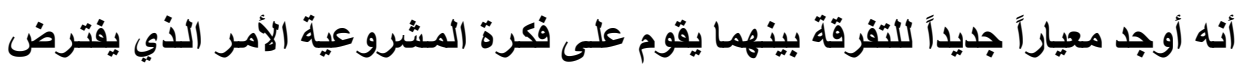

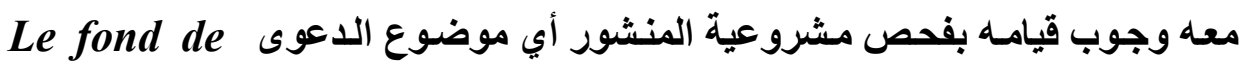
l'affaire

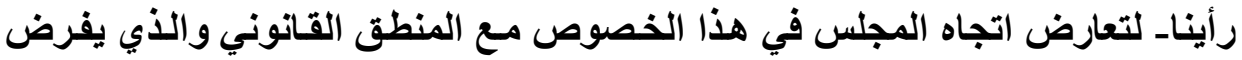
حسم مسألة قبول الدعوى قبل التعرض للموضوع أي قبل فحص مشروعية العدل محل فيل الطعن، بعبارة أخرى يوجب التأكد من أن الطعن موجه ضد عمل من شـأنه إحداث آثار قانونية، أو من شأنه أن يحدث ضرر وهو ما يعبر عنه بالفرنسية grief

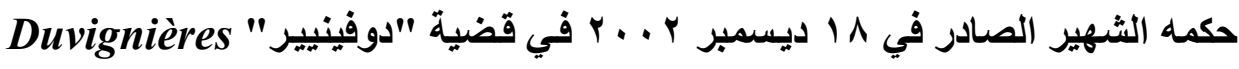

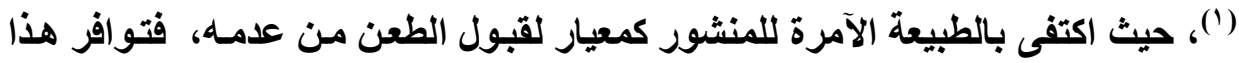

(1) CE, Sect., 18 déc. 2002, Duvignières;Rec.463, concl. Fombeur P ; RFDA 2003, p. 274, concl. Fombeur P. ; AJDA 2003, p. 487, chron. Donnat F. et Casas D. ; JCP 2003, n'5, p. 94, comm. Moreau J.; LPA juin 2003, $n^{\circ} 124$, note Combeau P., RFDA 2003, p.280, concl.et p. 510, note Petit J.

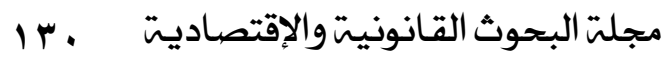


الوصف في المنشور أصبح كافياً في نظر المجلس- شريطة بطبيعة الحال توافر شروط

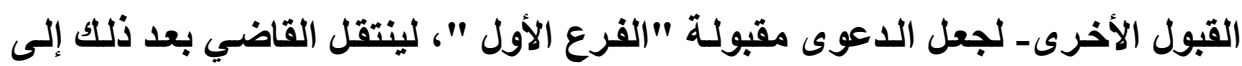

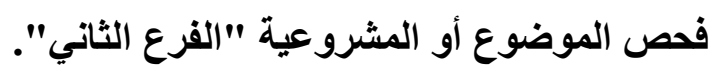

\section{الفرع الأول}

\section{الاكتفاء بالطبيسعة الآمهرة للامنشور}

قدمنا أن إعادة المنطق القانوني إلى نصابه الصحيح بشأن قبول الطعن بتجاوز السلطة ضد المنشورات يوجب الفصل بين القبول والموضوع بحيث لا يتم تعليق قبول إنى

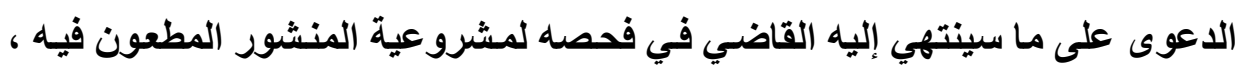

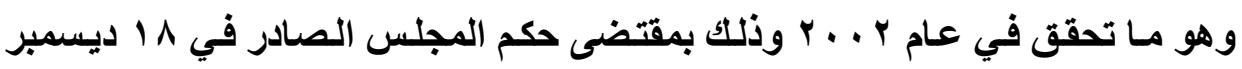

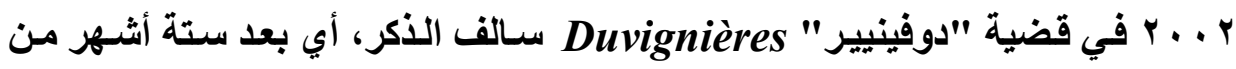

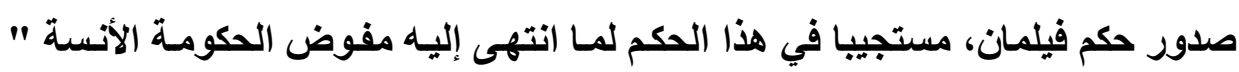

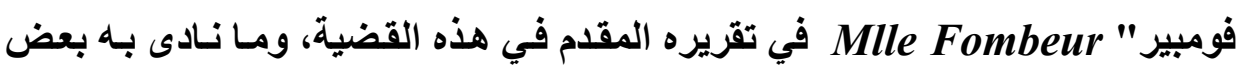
الفقهاء ـ كما رأينا ـ بشأن وجوب التخلي بالنسبة لقبول الطعن عن تقسيم المنشورات فئرهات إلى لائحية وتفسيرية والاعتماد فقط في هذا الخصوص على ما إذا كان ذات طبيعة آمرة من عدمه، حيث ذهب مجلس الاولة صراحة في هذا الحكم إلى أن " القواعد أو الأحكام الآمرة ذات الطـابع العـام للمنشور يجب النظر إليها على أن مـن شـأنها إحداث آثـار

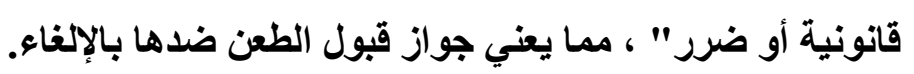

"Les dispositions impératives à caractère général d'une circulaire doivent être regardées comme faisant grief ".

وكما هو واضح فإن الربط بين مسألة القبول La recevabilité و والموضوع أصبح لا وجود له لصالح تأكيد المجلس من أن المنشور ذات الطابع العام المتضمن لأحكام آمرة يحدث بذاته آثار قانونية، ومن ثم يصبح من المقبول الطعن ضده 
بالإلغاء، بغض النظر عما إذا كان قد أضاف جديدا من عدمه أي دون التفات لما إذا كان ذات طبيعة لاتحية أو تفسيرية.

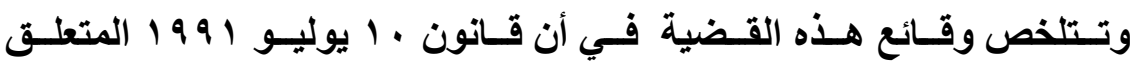

بالمسـاعدة القانونيـة L'aide juridique والتـي حلـ محل المسـاعدة القضائية (') L'aide judiciaire يتجـاوزه طالب المسـاعدة، مستبعداً عنــ حساب هذه المـوارد إعانـة السكن العـائلي Lبعضallocation de logement familiale Les prestations sociales à objet spécialisé

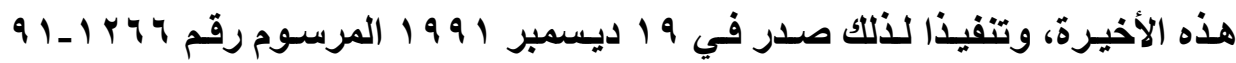
بشـأن تطبيـق هـا القـانون، حيث لـم يستبعد عنــ حساب المـوارد مسساعدة السكن الثخصية L'aide personnalisée au logement، ممـا يعنسي أنها على عكس

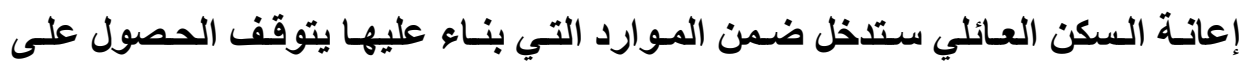

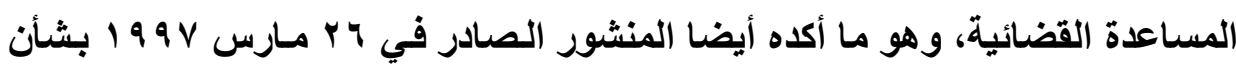

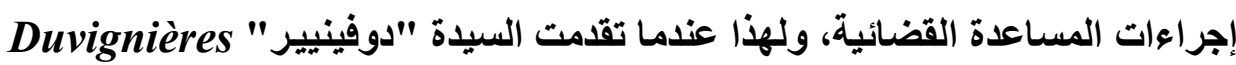

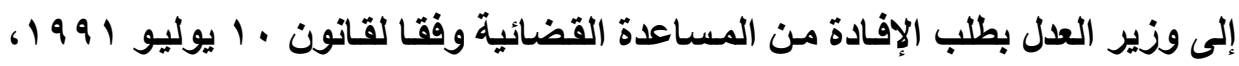
قوبل طلبها بالرفض وذلك تأسيساً على أن مواردهـا والتي حسبت من بينها مساعدة

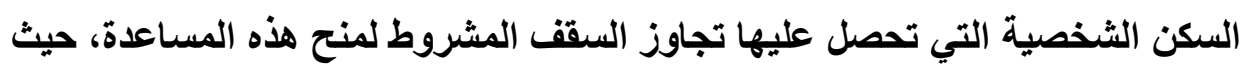

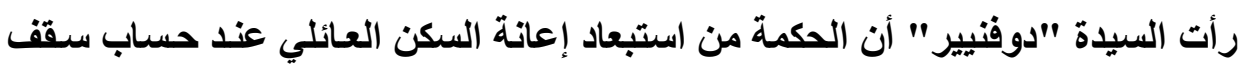

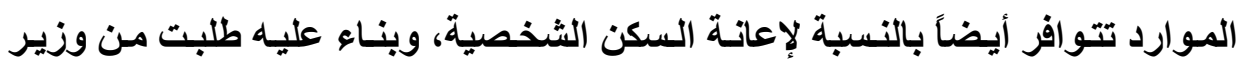

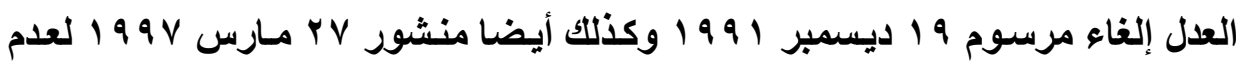

: راجع (1)

Long M. et autres, Les grands arrêts de la jurisprudence administrative, 17 e édition, Sirey, 2009, op.cit ,p. 848.

مجلت البحوث القانونيت والإقتصاديت r r r 
استبعادهما إعانة السكن الثخصية عند حساب موارد طالب المساعدة القضائية، إلا أن

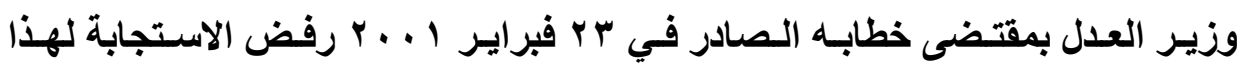

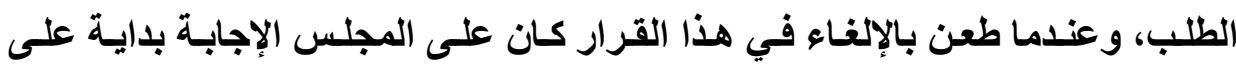
التساؤل التـالي: هل عدم استبعاد إعانـة السكن الثخصية التي يحصل عليها طالب المساعدة من الموارد التي بناء عليها يتحدد الحصول على المساعدة القضائية من عدمه يشكل إخلالاً بمبدأ المساواة ؟ بعبارة أخرى هل المقارنـة بين هذه الإعانـة وبين

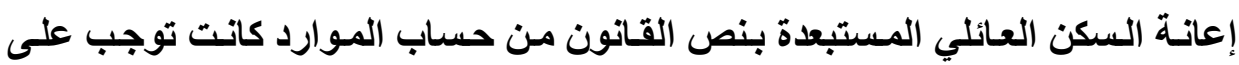
السلطة اللائحية إعمالا لمبدأ المساواة بين طالبي المساعدة القضائية مد نفس الحكم إلى إعانة السكن الشخصي، خاصة وأن منح إحداهما يستبعد الأخرى؟ وقد أجـاب المجلس عن هذا التساؤل بالإيجـاب وذلك تأسيساً على أن الغايـة poursuivent des الاجتماعية المستهدفة من منح كل منهمـا تعد واحدة أو متماثلـة بالجة باليل أن منح إحداهما يستبعد الأخرى، الأمر الذي finalités sociales similaires يوجب إعمـالا لمبدأ المساواة معاملـة طالبي المساعدة القضائية في الحسالتين معاملـة واحدة، بمعنى أنه يتعين عند حساب سقف الموارد المحددة للحق في الحصول على المساعدة القضائية عدم إدخال إعانـة السكن الثخصي ضمن موارد طالب المساعدة شأنه في ذلك شأن طالب المساعدة القضائية الذي يحصل على إعانـة السكن العائلي، وبنـاء على مـا تقدم انتهـي المجلس إلى إبطـال قرار وزير العدل والذي رفض فيـه

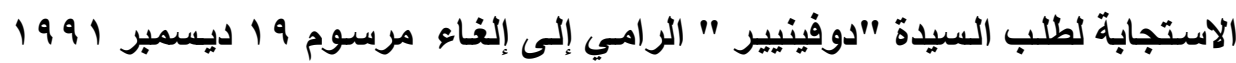
فيما تضمنه من عدم مساواة بين الإعانتين بثأن المساعدة القضائية. ولاشك أن مثل هذا الإبطال كان من شـأنه جعل الطعن في منشور rV مـارس 1997 دون فائدة، أي يغتي عن نظر هذا الأخير، ذلك أنه لم يفعل أكثر من مجرد ترديد

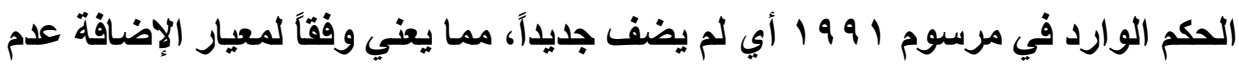
جواز قبول الطعن بتجـاوز السلطة سواء ضد المنشور نفسه، أو ضد القرار الصادر 
بـرفض إلغائسه، لكونـهـه فـي هـذه الحالــة لا يعـدو أن يكـون منسشوراً تفـسيرياً ولـيس

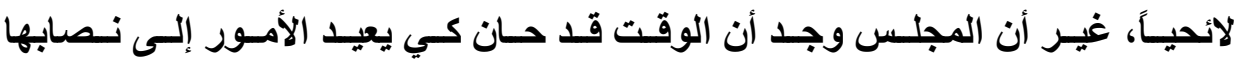

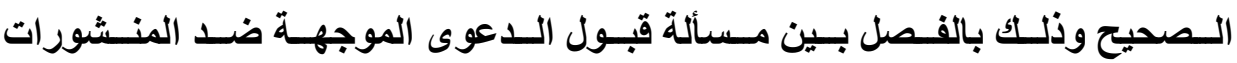
ومسشروعيتها، حيـث قبـل الطعن بتجـاوز السـلطة فـي رفضض وزيـر العـدل إلغــاء المنششور، وذلـك اسـتناداً إلى أن الأحكـام الـواردة في هذا المنشيور تعـد آمـرة وذات

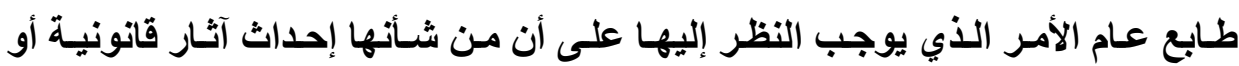
ضرر faisant grief، بعبارة أخرى الأمر الذي يضفي عليه وصف القرار،ممـا يعني قبول الطعن ضده بالإلغاء.

فـالطعن بتجـاوز الـسلطة ضــــ المنـشور وفقــا لقـضاء "دوفينييـر" أصـبح مقبـولاً، حتى وإن كسان يعـد طبقـاً لقضاء "نـوتردام كريسكر" منـشوراً تفسيرياً أي حتى وإن لم يضف جديدا للنص الأي يتولى تفسيره، طالمـا أنـه يتمتع بالصفة الآمرة،

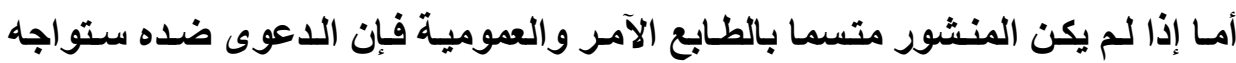
بعدم القبول. فقبول الطعن إذا وفقا لهذا القضاء لـ يعد يتوقف على مضمون المنشور وإنمسا على عموميتهـه والإلزام الذي يفرضسه بغض النظر عن مشروعيته والتـي يتم فحصها في المرحلة التالية أي عند فحص موضوع الطعن والادعـاءات التي يثيرهـا

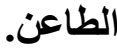

والواقع أن هذا الاستنتاج الذي انتهى إليه المجلس من أن المنشور الآمر ذات

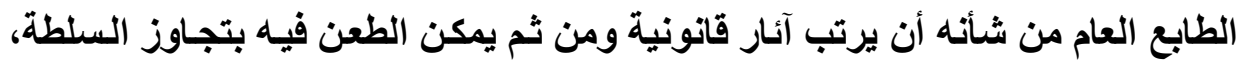
يمكن فهمه بسهولة إذا وضعنا في الاعتبار التحليل الفقهي السابق الإشـارة إليه والذي أظهر ضعف الأسـاس الذي اعتمد عليه المجلس بشأن قبول الطعن ضـد المنشورات، "C'est par souci de réalisme et فضلاً عن ذلك فبان الواقعية والفاعلية الونة d'efficacité" 
إلى تبنـي مثل هـا الحـل(')، ذلك أن المـوظقين بحكم خضوعهم للسلطة الرئساسية،

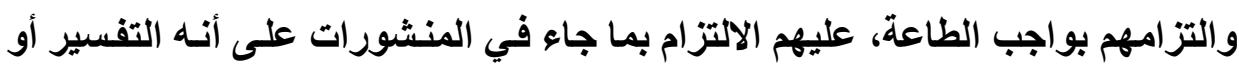

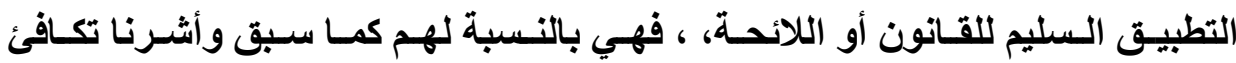

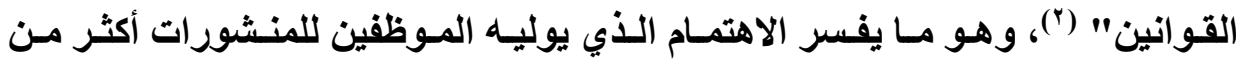
اهتمامهم بالنص الأي يتم توضيحه أو التعليق عليه، حيث يقومـون في الحقيقة باتخاذ

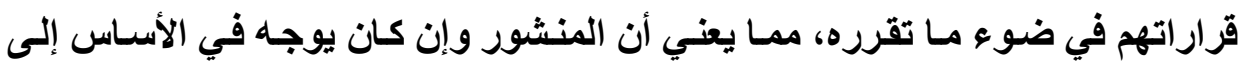

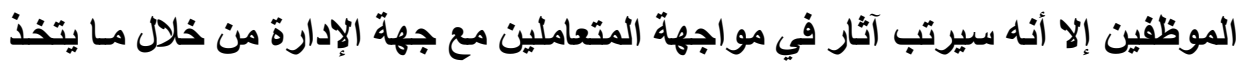
قبلهم من قرارات تطبيقا له.

وجدير بالذكر أنـه وقبل عـام r . . ب فبإن هنـاك العديد من الأحكام كانت تربط

الطبيعة اللائحية للمنشور ومن ثم قبول الطعن ضده بكون صياغته قد تمت في صورة

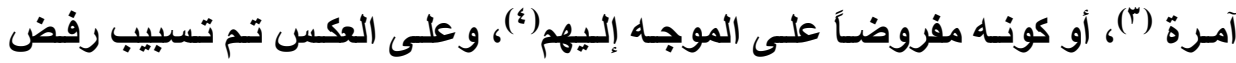

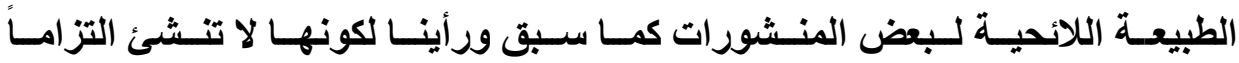

(1).Donnat F. et Casas D, chron. sous CE, Sect., 18 déc. 2002, Duvignières, AJDA 2003, p. 487, op.cit

(2) Valent autant que la loi"

Ripert G., Les forces créatrices du droit, LGDJ, 1955, p.369.

(3)CE ler avr. 1998, req. no 186535 et no 186802, Confédération générale du travail Force ouvrière et Confédération générale du travail, Rec.p.118;CE 20 mars 2000, Consorts Hanse, Rec.p. 120.

(4)CE 20 oct. 1999, Fédération des syndicats généraux de l'éducation nationale et de la recherche publique, Rec.p. 324 ; CE 20 oct. 1999, Époux Ait Ahmad, D. 2000. 251, concl. Schwartz.

مجلت البحوث القانونيت والإقتصاديت هب 
( )، أو لكونها لا تعدو مجرد إرشادات أو توضيحات()، أو توصيات(")، أو إعلان عن

غير أنه إذا كان قد تم وضع المنطق القانوني في نصابه الصحيح بالفصل بين

القبول والموضسوع، إلا أن الصعوبة سوف تكمن دون شكك في التمييز بين المنشور

الآمر وذلك الذي لا يتمتع بهذا الوصف ذلك أن حكم "دوفينيير" لم يعطي أيـة مؤشرات

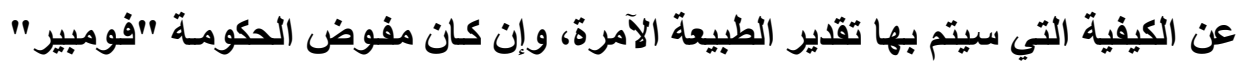

في تقريره المقدم في هذه القضية حاول تقديم بعض المؤشرات حيث ذهب إلى أن فكرة

المنشور الآمر يجب فهمها على أنها تعني "كل الأحكام التي تقصد من خلالها سلطة

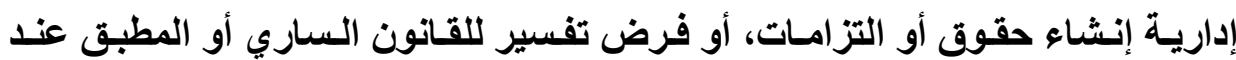

إصدار القرارات " (*)، ويناء عليه يتعين- في نظر مفوض الحكومةـ أن يستبعد من هذا

(1) CE 7 avr. 1993, Union nationale desassociations de parents d'enfants inadaptés,Rec.p. 547

(2) CE 18 nov. 1987, GISTI,Rec. p. 528 ; CE 5 juin 1989, Syndicat national de l'enseignement de l'éducation physique et sportive, Rec. p. 434 ; CE 26 oct. 1992, , Jonquet, Rec. p. 662 ; CE 16 févr. 1996, Société Ares et Iri Software, Rec. p. 666; CE 7 juin 2000, Société des agrégés de l'Université, Dr. adm. 2000. Comm. 186, obs. R.S.

(3)CE 4 juill. 1986, Syndicat national des enseignements secondaires et autres, Rec. p. 185 ; CE, sect., 6 mai 1996, Association Aquitaine Alternatives, Rec. p. 145 ; CE 25 avr. 1994, Min. Éducation nationale, Rec. p. 189 ; CE 18 oct. 2000, Association Promouvoir, RFDA 2000. 1372.

(4) CE 26 mai 1989, Mme Marabuto, Rec. p. 434.

(5)"Par dispositions impérative .... il faut entendre toutes les dispositions au moyen desquelles une autorité administrative vise soit à créer des droits ou des obligations, soit à imposer une interprétation du droit applicable en vue de l'édiction de décisions".

Fombeur P, concl. sur CE, Sect., 18 déc. 2002, Duvignières; op.cit .

مجلت البحوث القانونيت والإقتصاديت بس 
النطاق أحكام المنشورات التي تكتفي فيه السلطة الإداريـة بمجرد استعراض سياسـة، وكذلك أيضا تلك التي لا تؤثر على ما يجب اتخاذه من قرارات، وضرب لذلك مثلاً حكم

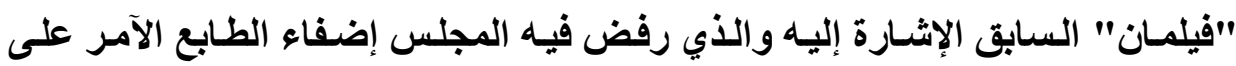

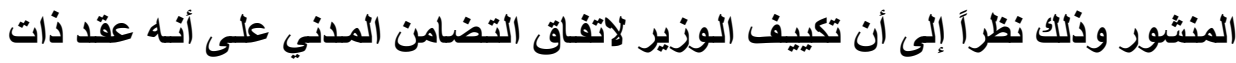

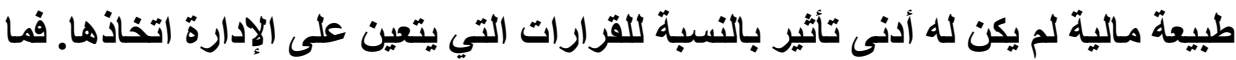
هو حاسم في تقدير مفوض الحكومة "فومبير" بالإضافة إلى صيغة المنشور هو قصد الإند

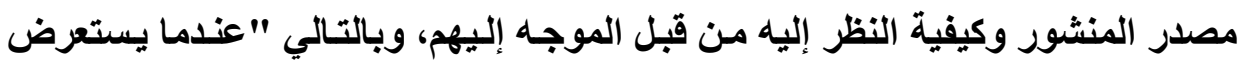

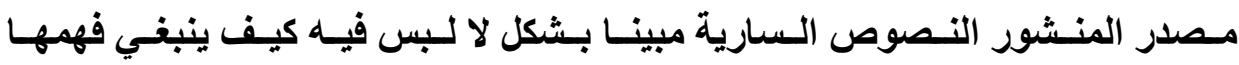
وتطبيقها، هنا يتعين النظر إليه على أنه منشور ذات طابع إلزامي (').

وفي جميع الأحوال فإنـه ينجم من أحكام القضاء التالية لحكم "دوفينيير" أن المنشور يجب النظر إليه على أنه آمر ومن ثم يقبل الطعن فيـه بتجاوز السلطة إذا كـان من شأنه أن يملي على الموظفين خط السير الذي يجب عليهم إتباعه، بغض النظر عما إذا كان من شأنه تعديل في الأوضاع القانونية من عدمـه، أي بغض النظر عمـا إذا كـان يضيف جليدا من عدمه.

(1)"Dès lors que l'auteur de la circulaire expose.. l'ensemble des règles applicables, en indiquant de façon univoque et non dubitative comment il faut le comprendre et l'appliquer, on peut considérer qu'il s'agit de dispositions à caractère impératif ".

Fombeur P, Ibid.

$$
\text { راجع أيضا: }
$$

Anastasia Iliopoulou, Quatre ans d'application de la jurisprudence Duvignères, RFDA 2007 p. 479; Petit J., Les circulaires impératives sont des actes faisant grief, op. cit, p.517,518.

Ir V مجلة البحوث القانونيت والإقتصاديت 
ولعل حكم المجلس الصادر في ^ أكتوبر ع . . ب في قضية الاتحساد الفرنسي

Union française pour la cohésion nationale للتلاحم أو التماسك الوطني يجسد بوضوح هذا المعنى حيث اعتبر المجلس المنشور الصادر من وزير التعليم

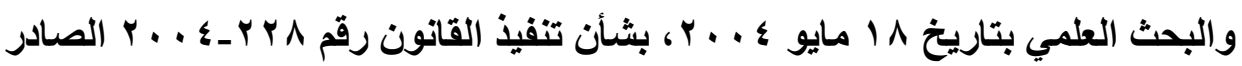
في 1 مارس \& . . ب المتعلق بتنظيم- وفقا لمبدأ العلمانية ـ حمل الشارات وارتداء الملابس التي تظهر الانتماء الديني في المدارس والمعاهد الحكوميةة(')، منشوراً آمرا ومن ثم قبل الطعن ضده رغم تأكيد المجلس بأن هذا المنشور اكتفى بمجرد التذكير وشرح عبارات هذا القانون elle s'est bornée à rappeler et expliciter les ttermes" ارتداء ملابس تظهر بوضوح ostensiblement انتماءاتهم الاينية، وإن كان قد انتهي

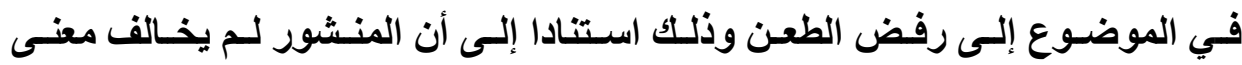

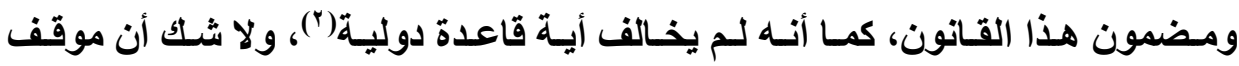
المجلس بالنسبة لقبول الطعن ضد هذا المنشور كان سيتغير فيمـا لو طبق قضاء " نوتردام كريسكر" حيث كان سيحكم بكل تأكيا بعدم القبول، باعتبار أن المنشور في هذه

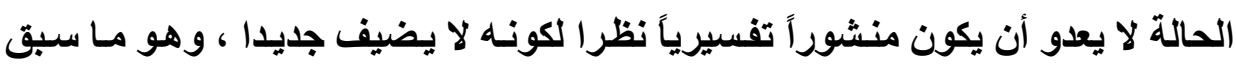

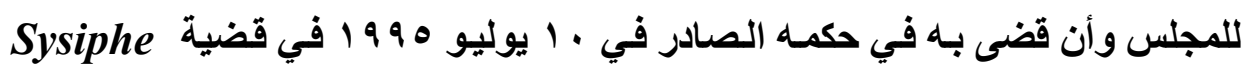
السابق الاشارة إليه، حيث رفض في هذا الحكم قبول الطعن في منشور وزير التعليم

(1) encadrant, en application du principe de lä̈cité, le port de signes ou de tenues manifestant une appartenance religieuse dans les écoles, collèges et lycées publics.

(2)CE, 8 octobre 2004, Union française pour la cohésion nationale, Rec. p.367; AJDA 2005, p. 43, note Rolin; RFDA 2004, p.977, concl. Keller ; JCPA 2004, 1849, note Tawil. 


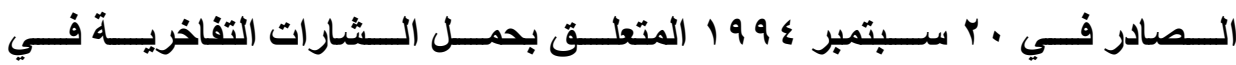
relative au port des signes ostentatoires dans les المسارس établissements scolaires تفسيرياً (1)

5F-1- وينفس الكيفية قضى المجلس بقبول الطعن ضد المنشور الضريبي رقم 99 الصادر في • ب ديسمبر 1991 199 بشأن نظام خصم النفقـات المهنيـة عند حساب الضريبة حيث أعتبره المجلس ذات طابع آمر ومن ثم قرر قبول الطعن ضده رغم التأكيد

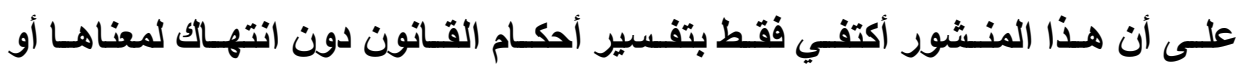

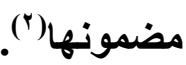

le juge des référés وهو مسا سـار عليه أيضا قاضسي الأمسور المستعجلة

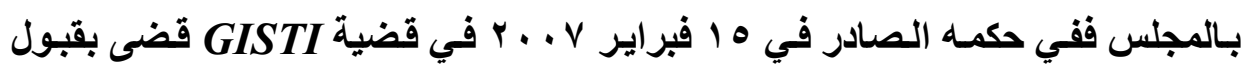

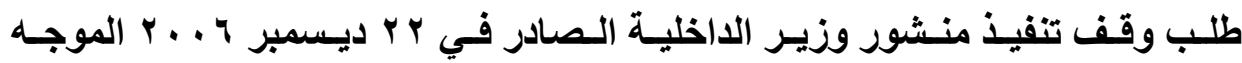

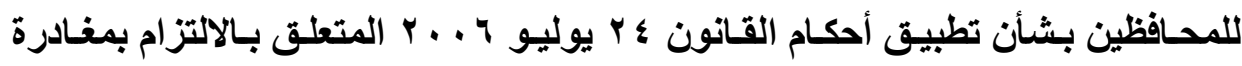
الإقليم الفرنسي، وذلك نظراً إلى أن التعليمـات التي تضمنها، بشأن التأكيد على أنسه

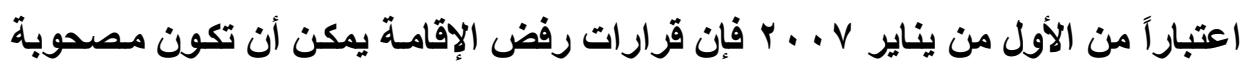
بـالإلزام بمغادرة الإقليم الفرنسي بعد انتهاء شـهر من صدور قرار الرفض، تعد ذات

(1)CE 10 juill. 1995, Association "Un Sysiphe », Rec. 292 ; AJDA 1995.644, concl. Schwartz ; DA févr. 1996, note Lajartre ; JCP 1995.II.22519, note Ashworth, op.cit.

(2)" se bornent à interpréter ces dispositions, dont elles ne méconnaissent pas le sens et la portée".

CE, 12 janvier 2004, Le Boucicaut, RJF avril 2004, $n^{\circ} 374$.

مجلتة البحوث القانونيت والإقتصاديت و س 
طبيعة آمرة، فضلاً عن إلزامه للمحافظين بمد الحكم الوارد في هذا القانون بثأن ترحيل

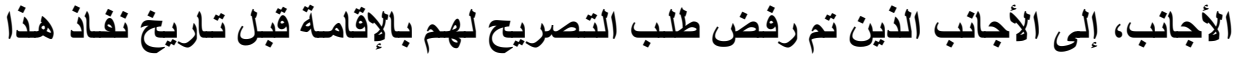

$$
\text { القانون في الأول من يناير عام V .... ץ ('). }
$$

أما إذا لم يكن المنشور من شأنه أن يملي على الموظفين خط السير الذي يجب

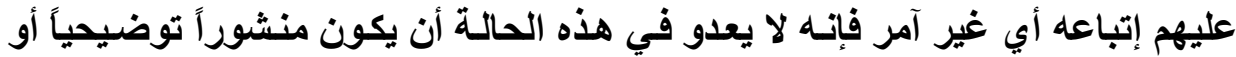
إرشادياً indicative لن يقبل الطعن فيه بالإلغاء، وهو ما حرص مجلس الدولة التهة التأكيد عليه في حكم "دوفينيير" السابق الإشـارة إليه حيث يقول" أن التفسير الذي تعطيه السلطة الإدارية عن طريق المنثورات للقوانين واللوائح، لا يمكن الطعن فيه بتجاوز

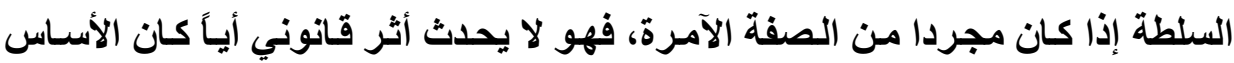

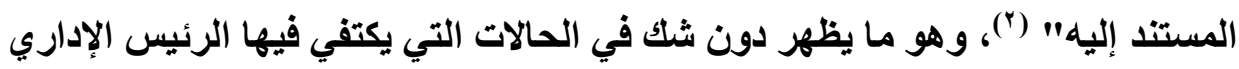

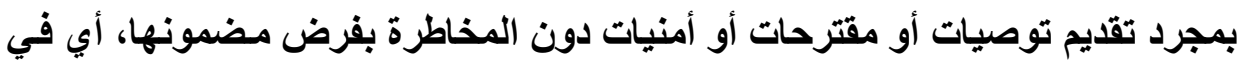
الحالات التي لا يكون الغرض من المنثور التحكم في القرارات التي ستصدر فيما بعد. ولكن السؤال هل يلزم أن يتضمن المنشور تفسيرا حتى يمكن قبول الطعن ضده بتجاوز السلطة ؟ بعبارة أخرى إذا اكتفى المنشور بمجرد ترديد نص القانون أو اللانحة

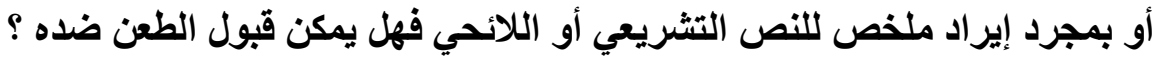

(1) CE, ord. réf., 15 février 2007, GISTI et a., requête numéro 300968, Inédite au Recueil Lebon.

(2)"que l'interprétation que par voie, notamment, de circulaires ou d'instructions l'autorité administrative donne des lois et règlements qu'elle a pour mission de mettre en cuvre n'est pas susceptible d'être déférée au juge de l'excès de pouvoir lorsque, étant dénuée de caractère impératif, elle ne saurait, quel qu'en soit le bien-fondé, faire grief".

مجلت البحوث القانونيت والإقتصاديت 
الواقع أن مجلس الدولة الفرنسي مر في هذا الخصوص بمرحلة تردد :

ففي البداية لم يعتبر المجلس من قبيل المنشورات الآمرة، المنشورات التي لا

تعدو مجرد صورة simple photographi أو نسخ ولصق copier-coller للقواعد

التثريعية أو اللائحية النافذة، أو ملخص لتلك القواعد، وهو ما قرره صراحة في حكمهـ الصادر في ؛ فبراير ع . . ب في قضية OPHLM de Seine-et-Marne، متبنياً في ذلك وجهة نظر مفوض المكومة Bachelier في تقريره المقدم في هذه القضية، فبعد أن ردد المجلس نفس العبارات الواردة في حكم "دوفينيير" سـالف الإشـارة إليهه نجده يقرر بأن المنشور الضريبي الصادر في 10 ديسمبر 9199 19شأن تقيبيم العقـارات المبنية وغير المبنية في الفترة من ع 19 إلى • 19 1 " قد اكتفي بمجرد تلخيص التعديلات الني أدخلها المشرع... والتذكير بالنظام الساري، فلم يكن موضوعه إعطاء تفسيرات والتي إذا كاتت آمرة يجب النظر إليها على أنـه من الممكن أن ترتب آنثار قانونية ، ومن ثم فإن مكتب الإسكان المتوسط... ليس من حقه طلب إلغائه" ( '). ولا شــك أن هـا القضضاء مسن شـأنه أن يقلـل مسن الفائسدة التـي أضسافها حكـم "دوفينيير "، أو بعبارة أخرى يعد بمثابة عودة للخلف، ذلك أن معنـاه بقاء منشورات

(1)"se bornent à résumer les modifications apportées par le législateur.. et à rappeler le régime applicable depuis lors; qu'elles n'ont pas pour objet de donner de ces dispositions législatives une interprétation qui, par son caractère impératif, devrait être regardée comme faisant grief ; que, dès lors, l'OFFICE PUBLIC D'HABITATIONS A LOYER MODERE DE SEINE-ET-MARNE n'est pas recevable à demander l'annulation des instructions attaquées ".

CE, 4 février 2004, OPHLM de Seine-et-Marne, Dr. fisc. 2004, $n^{\circ} 40$, comm. 740, RJF avril 2004, $n^{\circ} 406$, chron. Olléon L. ; BDCF avr. 2004, $n^{\circ}$ 53, concl. Bachelier $G$.

مجلت البحوث القانونيت والإقتصاديت | 
تردد عدم مشروعية دون رقابة قضائية لمجرد كونها لا تعدو مجرد ترديد للحكم الوارد في القانون أو اللائحة رغم أن مـا تم ترديده يعد غير مشروع(')، في حين أن كون المنشور في هذه الحالة قد ألزم الموجه إليهم بتطبيق تلكا الأحكام غير المشروعة فإنها بذلك يكون قد أحدث أثرا، ولهذا كـان طبيعيا أن يواجه هذا القضاء بهجوم من جانب العديد من الفقهاء، ففي تعليقه على هذا الحكم ذهب الأستاذ أوليون Olléon إلى أن حكم مكتب الاسكان المتوسط بإضـافته إلى جانب الشرط المتعلق بالطـابع العام والآمر للأحكام محل الطعن شرطا يتعلق بضرورة تضمن المنشور لتفسير...من شأنه أن يؤدي إلى تعقيد الأمور ()، وذلك نظر الصعوبة تحديد مـا إذا كنـا في الحقيقة أمسام تفسير من عدمه، فهي مسألة سيختلف فيها التقدير من قاض إلى آخر أي سيفلب عليها التقدير (الشخصي(") ولهذا كان طبيعياً أن يتظلى المجلس في أحكامـه التالية عن هذا القضاء، ففي

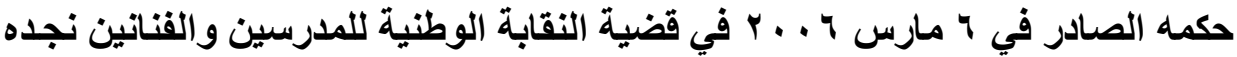
يقرر بأنه " إذا كان وزير الاقتصاد والمالية قد استثد إلى أن المنشور قد اكتفى بمجرد تلخيص التعديلات التي أدخلها المشرع بالنسبة للنص المتعلق بخصم النفقات المهنية، ومن ثم لا يجوز مهاجمته أمام قاضي تجاوز السلطة، هذا الدفع يجب استبعاده، ذلك أنها

$$
\text { في هذا المعنى راجع: }
$$

Anastasia Iliopoulou, op.cit, p. 484 et s.

(2) " à la condition relative au caractère impératif et général des dispositions litigieuses, la décision Office public départemental d'habitations à loyer modéré de Seine-et-Marne en ajoute une autre, relative à la nécessité d'une interprétation (...) qui va surtout compliquer les choses". éon L., Recours pour excès de pouvoir contre les instructions fiscales : la photographie du droit existant n'est pas contestable, RJF 4/2004, p. 271.

(3)Ibid.

مجلتّ البحوث القانونيت والإقتصاديت ب ا 
طالما أن المنشور يتمتع بالطابع الآمر فهو قابل للطعن فيه بتجاوز السلطة" (')، وقد

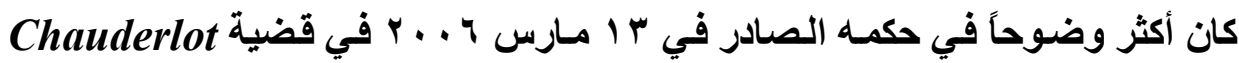
حيث قرر صراحة ـ متبنيا وجهة نظر مفوض الحكومـة Glaser بأن " الأحكام الآمرة ذات الطابع العام لمنشور يجب النظر إليها على أنه من المكن أن ترتب آثار قانونية، حتى وإن اكتفت بمجرد تكرار أو ترديد قاعدة سبق وأن وردت في قاعدة قانونية أعلى

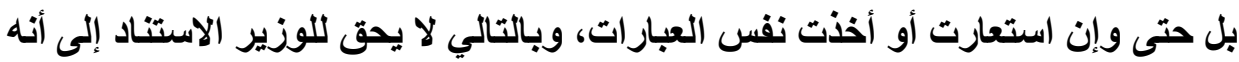

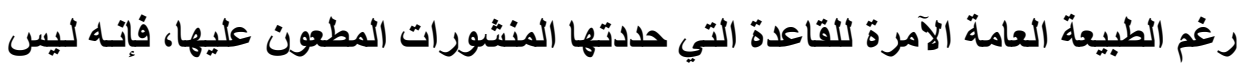

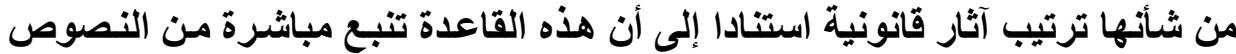

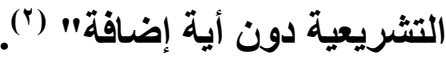

(1)"que, si le ministre de l'économie, des finances et de l'industrie soutient que l'instruction se borne à résumer les modifications apportées par le législateur au dispositif concernant les déductions pour frais professionnels et que, par suite, elle n'est pas susceptible d'être déférée au juge de l'excès de pouvoir, ce moyen doit être écarté dès lors que l'instruction présente un caractère impératif ; qu'elle est donc susceptible de faire l'objet d'un recours pour excès de pouvoir".

CE 6 mars 2006, Syndicat national des enseignants et artistes, Rec.p. 107.

(2)"Les dispositions impératives à caractère général d'une circulaire ou d'une instruction doivent être regardées comme faisant grief, alors même qu'elles se borneraient à réitérer une règle déjà contenue dans une norme juridique supérieure, le cas échéant en en reprenant les termes exacts; que par suite le ministre n'est pas fondé à soutenir qu'en dépit du caractère général et impératif de la règle qu'elles fixent, les circulaires contestées ne feraient pas grief, au motif que cette règle découlerait directement des textes législatifs, auxquels il ne serait donc rien ajouté".

CE 2 juin 2006, Chauderlot, RJF $06 n^{\circ} 1035$, DF 46/06 $n^{\circ} 725$ concl. GlaserE.

مجلة البحوث القانونيتو الإقتصاديت بـ ا 
وأخذا بالمفهوم الواسـع لفكرة المنشور من حيث كونـه يمكن أن يغطي أعمالاً

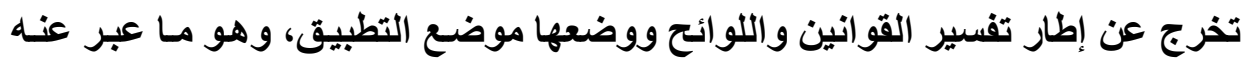
مفوض الحكومـة تريكو من قبل في تقريره المقدم في قضية " نوتردام كريسكر " السابق الاشـارة إليه ـ بقوله " أن المنشور عبارة عن سر سرادق يمكن أن يشتمل على كل

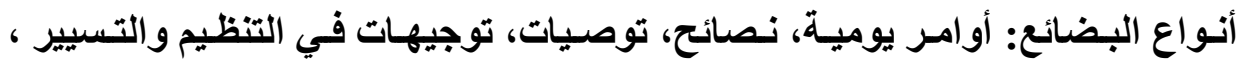

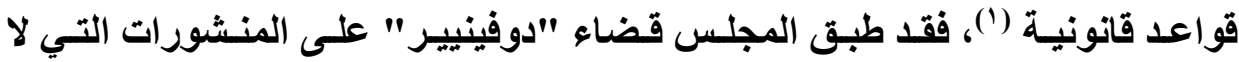

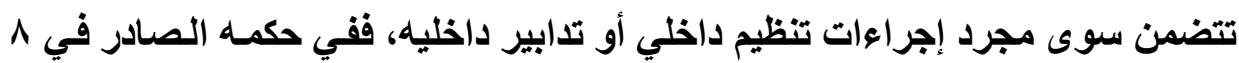

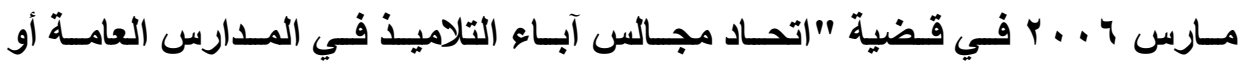
الحكومية" ذهب صراحة إلى أن " تعلق المنشور المطعون فيه بالعقوبـات المدرسية mesures و والتـي تعـد مسن إجـراءات النظـام الــاخلي punitions scolaires d'ordre intérieur المطعون عليها ذات طابع آمر " (`)

ويتعلق بسلسلة من المنشور ات صدرت بشأن التز امات الممول حال قيامه بنقل موطنه الضريبي son domicile fiscal

راجع أيضًا:

(1)" la circulaire est un pavillon qui peut recouvrir toutes sortes de marchandises: ordres $d u$ jour, conseils, recommandations, directives d'organisation et de fonctionnement, règles de droit ".

Tricot B., concl. sur CE.29 janv. 1954, Institution Notre-Dame du Kreisker,op.cit, p..50.

(2)"Considérant que la circonstance que la circulaire attaquée porte sur les punitions scolaires, qui sont des mesures d'ordre intérieur, ne fait pas obstacle à ce qu'elle puisse faire l'objet d'un recours pour excès de pouvoir ; que les dispositions attaquées ayant un caractère impératif".

CE 8 mars 2006, Fédération des conseils des parents d'élèves des écoles publiques, Rec.p. 112 , AJDA 2006.1107, concl. Keller, DA 2006, $n^{\circ}$ 97, note Taillefait 


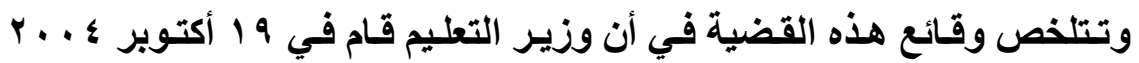

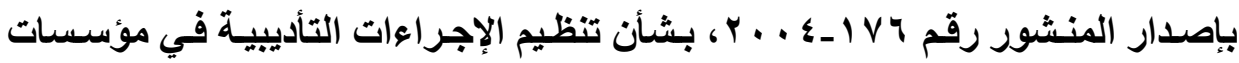

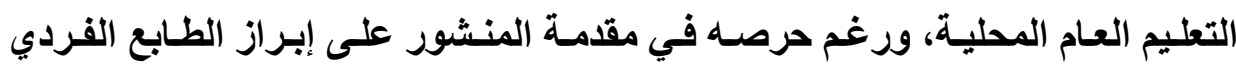

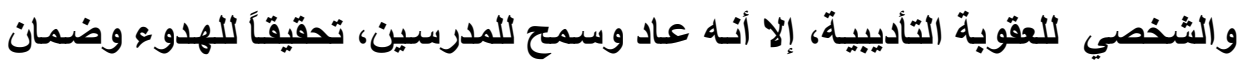
فعالية التدريس، بالحق في معاقبة سلوك مجموعة محددة من التلاميذ تعرقل أو تعطل

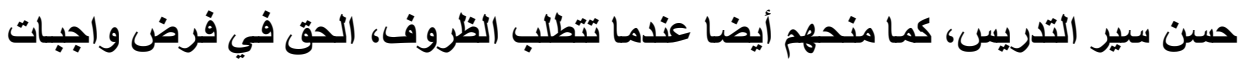

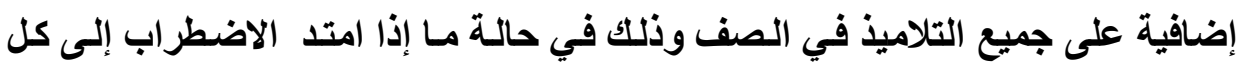

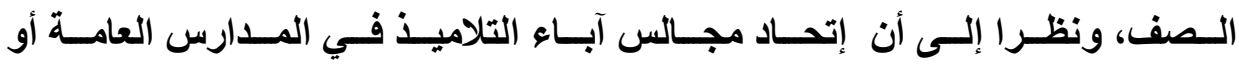
Fédération des conseils de parent d'élèves des écoles الحكومية

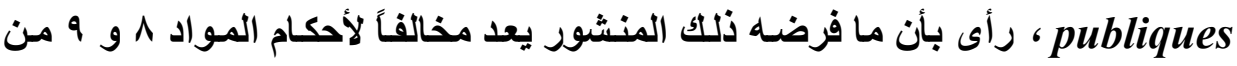

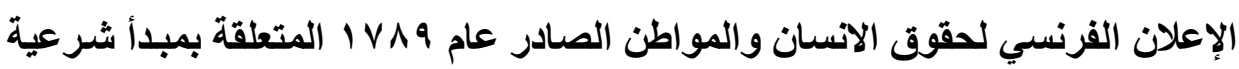

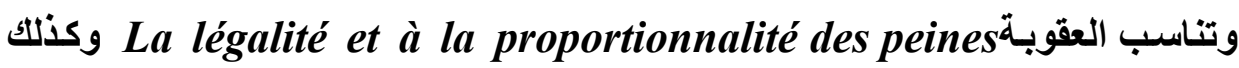
أيضاً مبدأ افتراض البراءة La présomption d'innocence فقد قام بالطعن

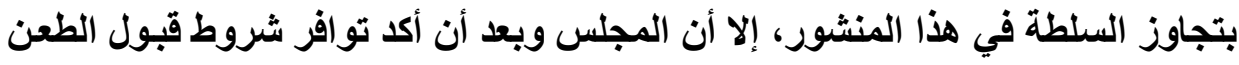
بالنظر للطبيعة الآمرة للمنشور، رغم تعلقه بالعقوبات المدرسية والتي تعد من أبرز

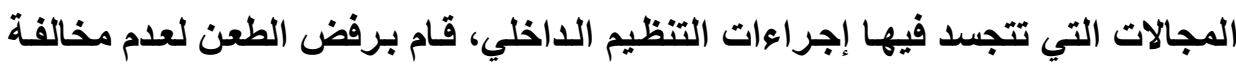

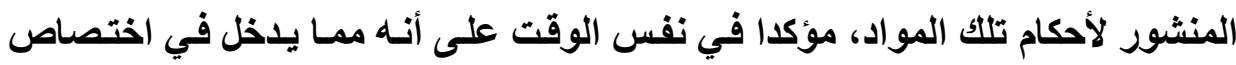

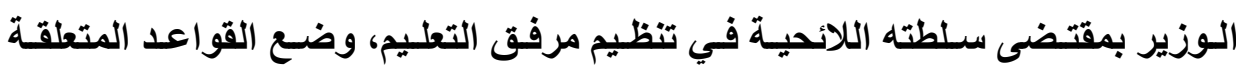

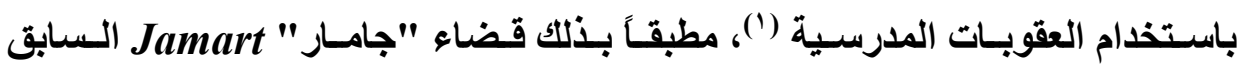

(1)"Considérant que le ministre de l'éducation nationale, de l'enseignement supérieur et de la recherche était compétent, au titre de son pouvoir réglementaire d'organisation du service public de l'enseignement, pour édicter des règles relatives à l'usage des punitions scolaires ".

مجلة البحوث القانونيت والإقتصاديت ـ 1 
الإشـارة إليه والذي اعترف للوزراء دون حاجة إلى نص بسلطة إصدار اللوائح اللازمـة لحسن تسيير وتنظيم المرفق.

غير أن المجلس وإن كـان قد أجاز الطعن في المنشورات التي تتضمن أحكام تتعلق بـإجراءات التنظيم الـاخلي، إلا أنـاه لـم يجز للعـاملين في المرفق الطعن في المنشورات التي تعد في حد ذاتها تلبير داخلي باعتبار ها تتعلق في هذه الحالة بتنظيم المرفق وتسبيره خاصـة تلكك الموجهة من جانب الرؤسـاء للمرؤوسين بشأن تفسير النصوص المكلفين بتطبيقها، وذلك باستثناء مسا إذا كانت تتضمن مساس بحقوقهم وامتيازاتهم أو أوضاعهم الوظيفية(') وإذا كانــت القاعـدة أن المنـشورات إنمـــا توجـهـ مـن الــرئيس الإداري إلـى المرؤوسين التابعين له أي الخاضعين لسلطته الرئاسية، إلا أن علاقة التبعية بالنسبة لمجلس الدولة الفرنسي ليست ضرورية لإضفاء الوصف الآمر على المنشور، حيث اعترف المجلس بذلك الوصف ومن ثم قبل الطعن ضد المنشور رغم أنه يخاطب جهات لا تـربطهم بمـصدر المنشور علاقـة تبعيـة (؟)، بـل حتى وإن كــان لا يتوجـه بالخطـاب

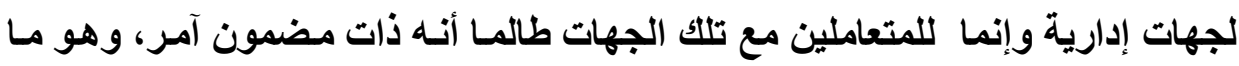

(1)CE 23 juill. 2003, Syndicat SUD Travail, req. $n^{\circ}$ 251148, Rec. p. 342, concl. Stah. J.-HKoubi G., L'irrecevabilité des requêtes des agents publics contre les instructions de service interprétatives, JCP A., $\mathrm{n}^{\circ} 6$, 2 février 2004, Jur. 1065, p. 146.

(2)CE. 5 nov. 2004, SA Intelmatique e.a, Rec. Lebon T. 566, 738, concl. Devys C.

ويتعلق بمنشور صادر من كل من وزير الوظيفة العامة ووزير الاقتصاد موجـه لنظر ائهم بشأن

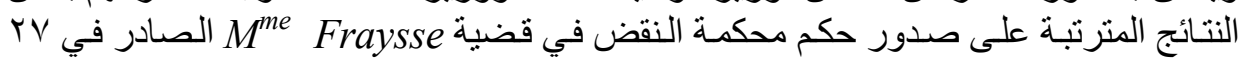




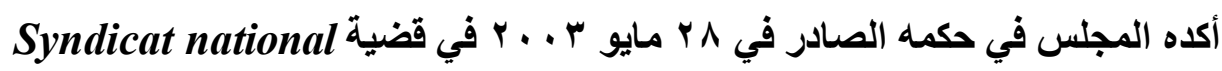
de l'industrie pharmaceutique الحكومة "فومبير" Fombeur التي عرض لها في تقريره المقدم في هذه القضية

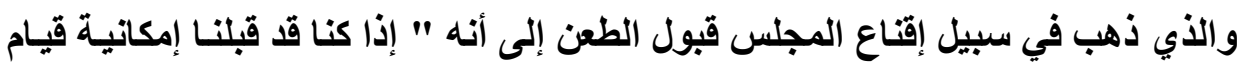

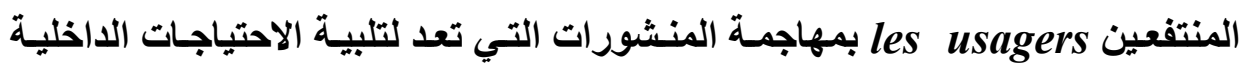
للإدارة، فإنه من باب أولى يتعين قبول الطعن ضد المنشورات الموجهة إليهم مباشرة و التي تتضمن نفس النوع من التفسير" ويقصد بذلك التفسير الآمر (†).

(1)CE 28 mai 2003, Syndicat national de l'industrie pharmaceutique, req. $n^{\circ} 240795$, inédit, concl. Fombeur $P$.

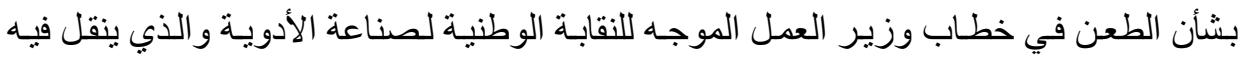

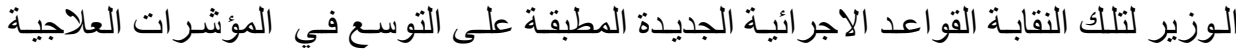
extension des indications thérapeutiques قيمته، فضلا عن مطالبته لرئيس النقابة بإبلاغ شركات الأدوية بهذا الأمر.

(2)" si l'on admet que les usagers puissent attaquer des circulaires rédigées pour les besoins internes de l'administration, il y a lieu a fortiori d'admettre leur recevabilité à déférer des actes qui leur sont directement adressés et qui comportent le même type d'interprétation".

Fombeur P.. Ibid.

و هي نفس الوجهة التي عرض لها مفوض الحكومة Devys في تقريره المقدم في قضية العابل

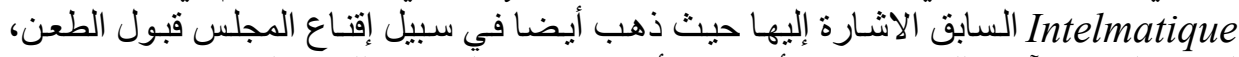

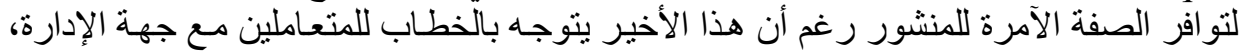

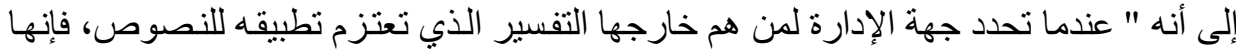
في هذه الحالة تعطي ضمنياً لمر افقها أمر بإنباع هذا التفسير ". "lorsque l'administration décrit à l'extérieur l'interprétation des textes qu'elle entend retenir, elle donne implicitement à ses propres services ordre de suivre cette interprétation". 
كمـا اعترف المجلس في أحكامسه اللاحقـة لحكم "دوفنيير " بالطبيعـة الآمـرة للمنشور، حتى وإن كان قد سمح على سبيل الاستثناء بإمكانية الخروج على أحكامـه،

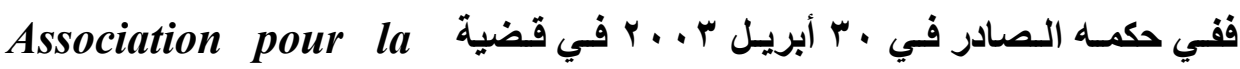
défense des libertés des éleveurs للتعليمات لا تتأثر بكون الوزير احتفظ لنفسه في نهايـة المنشور بـالحق في أن يمنح

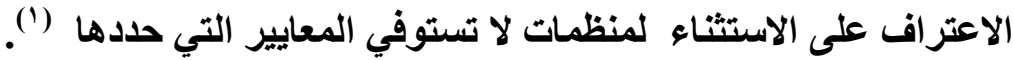

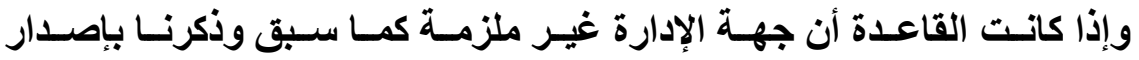

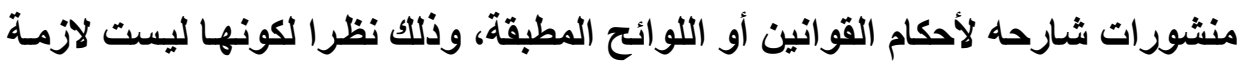
لتنفيذها ووضعها موضـع التطبيق ،ومن ثم فبإن رفض إصدارها لا يمكن أن يتضمن

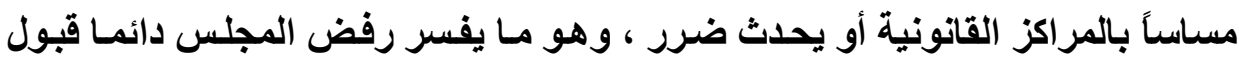
الطعن ضد رفض جهة الإدارة الاستجابة لطلب إصدار منشور سواء قيل صدور حكم

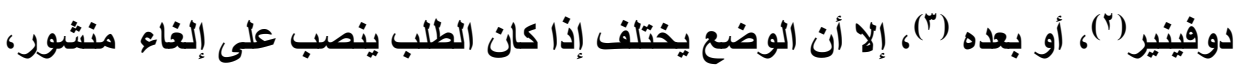

(1) "le caractère impératif de ces consignes n'est en l'espèce pas affecté par la circonstance que le ministre a mentionnée, à la fin de sa circulaire, qu'il se réservait la possibilité d'accorder exceptionnellement [faculté de dérogation] la reconnaissance à des organisations qui ne rempliraient pas ces deux critères".

CE 30 avr. 2003, Association pour la défense des libertés des éleveurs et des acteurs des filières de l'élevage, req. $n^{\circ} 242637$, concl. Séners $F$.

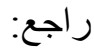

Groulier C., L'impératif dans la jurisprudence Duvignères : réflexion sur un " sésame contentieux », RFDA 2008 p. 947.

(2)CE 8 déc. 2000, Syndicat SUD PTT Pays de Savoie, Rec.p.1141.

(3)CE 14 mars 2003, Le Guidec, Rec. P.897, AJDA 2003, p.1446, note Koubi G., LAP nov. 2003, $n^{\circ} 221$, note Seiller B: " l'administration $n^{\prime}$ est jamais tenue de prendre une circulaire pour interpréter l'état du droit existant". 
حيث اعتبر المجلس أن رفض جهة الإدارة الاستجابة لهذا الطلب يشكل قرارا يمكن

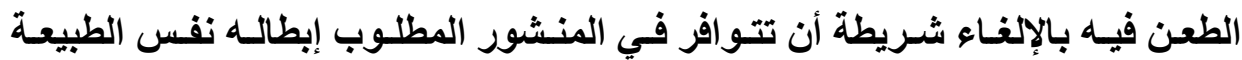
اللازمة لقبول الطعن ضده أي الطبيعة الآمرة (')، أما إذا كان غير آمر فلا يجوز الطئن الطعن

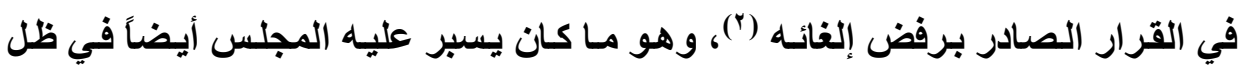
قضاء " نوتردام كريسكر" حال فقدان المنشور للطبيعة اللائحية ("). وجدير بالذكر أن الطبيعة الآمرة للمنشور وإن كانت قد أصبحت هي المعيـار الذي يعتد به بشأن تحديد المنشورات التي يقبل الطعن ضدها بالإلغاء، إلا أن توافر تلك

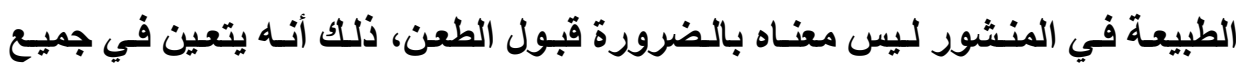
الأحوال لقبول الطعن توافر شرط المصلحة l'intérêt à agir ، وهو مـا قد لا يتوافر سواء في جانب الموظفين نظراً لعدم مساس المنشور بحقوقهم وامتياز اتهم وأوضساعهم الوظيفية، أو في جانب المتعاملين مـع جهة الإدارة، لعدم تعلث المنشور بهم، ويظهر ذلك في حالة ما إذا كان المنشور الآمر غير موجه لمن يتمتع بصلاحية إصدار القرارات

$$
\text { (1) (1) بالإضافة لحكم دوفيرنيه راجع: }
$$

CE 3 oct. 2003, Boonen, AJDA 2003, p. 1847, obs. Brillé M.;- CE 18 mai 2005, Eglise de scientologie, Rec. p. 201, AJDA 2005, p. 1506, concl. Donnat F;- CE. 5 janvier 2005, Mazzoni, Dr. Fisc. 2005, comm. 390, concl. Glaser ;- CE 26 sept.2005, conseil nat. de l'Ordre des médecins, Rec. p. 395,AJDA 2995, p. 1873, obs. Aubert F.

$$
\text { (Y) (ب) راجع على سبيل المثال: }
$$

CE 19 fevr.2003, Soc. Auberge Ferme des Genets, Rec. p. 897.

(3)CE 22 dec.1978, Fédérat. nat.des travaux publics, Rec. p.522-; CE 20 oct.1999, Fédérat.des synd. de l'éducat. nationale, R. p.324. 
و إنما إلى من لا تتعدى صلاحيتهم الاقتراح (1)، ذلك أن المنشور في هذه الحالة لن يكون

$$
\text { له سوى تأثير غير مباثر على ما سيتخذ من قرارات ("). }
$$

فالجديد إذن في معيار الطبيعة الآمرة المستمد من قضاء دوفيرنيه أنـه أصبح

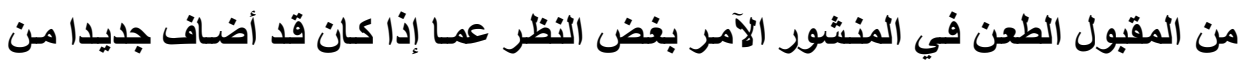

عدمه، وبغض النظر أيضا عن مدى مشروعيته، أي أنه وضع بثأن قبول الطعن نهايـة

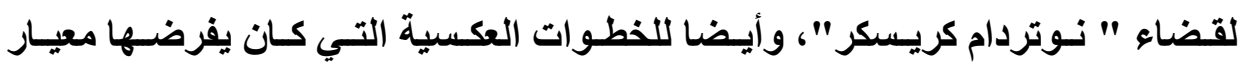

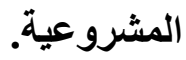

غير أنه من زاوية أخرى فإن الأمثلة والنماذج السابق تقديمها وإن كانت تسمح

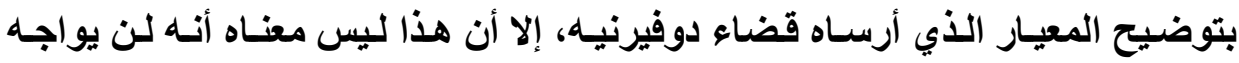

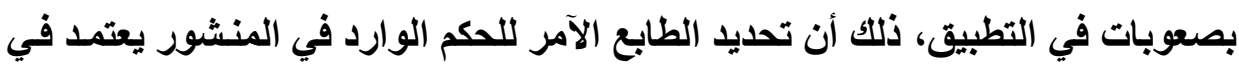

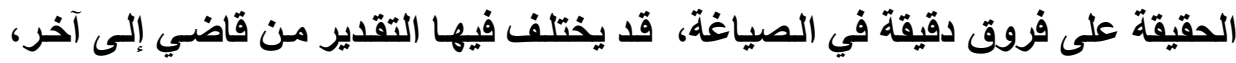

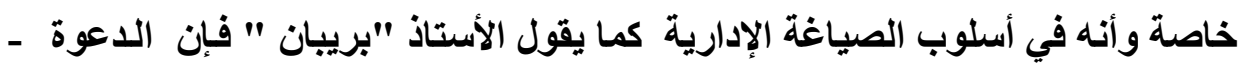
l'invitation لتوصية (")، فضلا عن ذلك وكما هو الثأن بالنسبة لمعيار الإضافة أو الاستحداث،

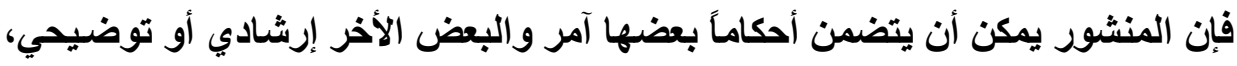

(1) CE, 10 juill. 1995, Association «Un Sysiphe », Rec. p. 292 ; AJDA 1995, p. 644, concl. Schwartz R.; CE, 27 nov. 2000, Mme Ohayon, Rec. p. 558.

(2) Fombeur P., Concl. sur CE, Sect., 18 déc. 2002, op.cit; Petit J., Les circulaires impératives sont des actes faisant grief, op.cit, $p .517$.

(3)" dans le style administratif, l'invitation peut être la forme polie d'un ordre ou la forme pressante d'une recommandation"

Braibant, Concl. sur CE, 13 juill. 1962, Conseil national de l'Ordre des médecins, RDP 1962, p. 739.

$$
\text { 10 مجلت البحوث القانونيت والإقتصاديت }
$$


مما يعني قبول الطعن ضد الأولى دون الثانية (')، وهو ما يشكل صعوبة أخرى تضاف إلى الأولى، وقد عبر الأستاذ "لونج " Long عن تلك الصعوبات بقوله " إن الخط الفاصل ( ويقصد بذلك بين ما هو آمر وما هو توضيحي أو إرشـادي) وإن كان واضحا من حيث المبدأ، إلا أنـه يمكن أن يتضمن مـن الناحية العمليـة تعرجـات أو انعطافـات ( $\left.{ }^{(}\right)$" sinuosités

(1) (1) بالإضافة لحكم Villemain سالف الذكر راجع: CE, 30 déc. 2002, Syndicat CGT des ministères des Affaires sociales et Du travail, non publié

$$
\text { مشار إلبه في : }
$$

Petit J., Les circulaires impératives sont des actes faisant grief, op.cit, $p$. 517.

(3)" La ligne de partage, claire dans son principe peut comporter en pratique des sinuosités".

Long M. et autres, Les grands arrêts de la jurisprudence administrative, 17 édition, Sirey, 2009, op.cit., p. 854.

راجع حكم المجلس: :CE, 24 févr. 2003, M. X non publié بشأن منشور يتعلق بإعداد

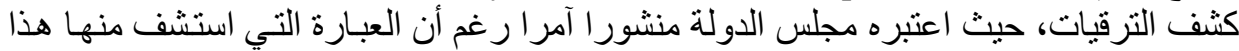

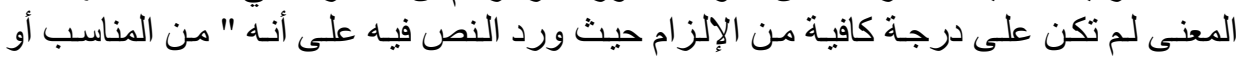

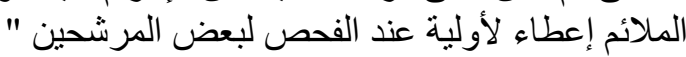
qu'il "conviendra d'examiner en priorité " certaines candidatures".

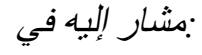

Petit J., op.cit., p. 515.

مجلتة البحوث القانونيت والإقتصاديت 101 ما 


\section{الفرع الثاني \\ فص مشروعية المنشورات الآهرة}

إذا توافر للمنشور أو لبعض أحكامه الطابع الآمر، وتوافرت الثروط الأخرى

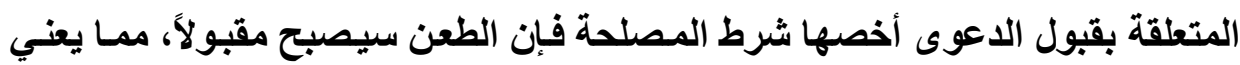

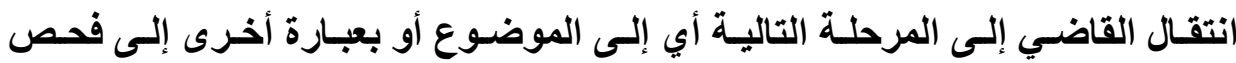

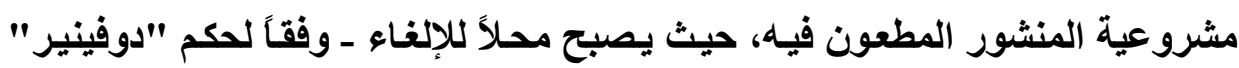

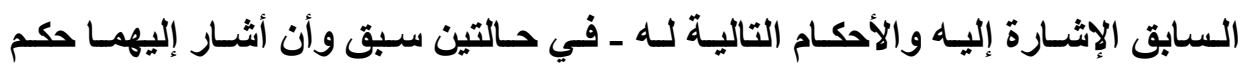

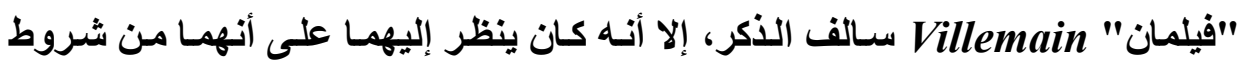

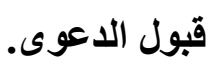

الفرض الأول: قيام المنشور بفرض قاعدة جليدة معيبة بعدم الاختصاص أو بأي

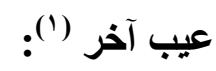

هنا في الواقع نكون أمام المنثور اللانحي الأي صوره قضاء معهر " نوتردام كريسكر" Notre-Dame du Kreisker، والذي يتمثل في إضافة المنشور قاعدة جديدة للنصوص التي يتولى تفسيرها دون أن يكون مصدرها متمتعاً بالسلطة اللانحية، في هذه الحالة فإن المنشور يبطل لعدم الاختصاص. وتطبيقا لذلك قضي بإلغاء منشور وزير الاقتصاد والمالية والصناعة والذي قام

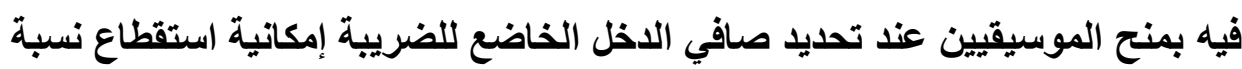
تتراوح بين ؛ ا في المائة وه في المائة من الدخل السنوي مقابل النفقات الفعلية

(1)"La circulaire fixe une règle nouvelle entachée d'incompétence ou d'une autre illégalité". 
frais réels ، وقد استند المجلس في حكمه إلى عدم وجود أي نص تشريعي يمنح الوزير سلطة وضع مثل هذه القواعد('). كما قضى أيضاً بإلغاء منشور وزير الاقتصاد

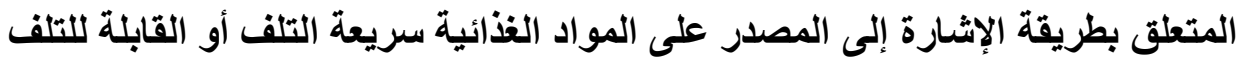
les produits alimentaires périssables ، وذلك نظراً إلى أن الوزير لم يقتصر

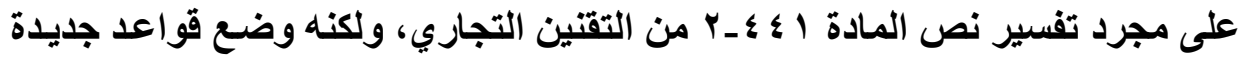
تفرض بالنسبة لكل المواد الغذائية القابلة للتلف ـ المصنعة أو المجهزة أو المحولة من مواد أولية ـ الإشـارة إلى دولة التصنيع أو التجهيز ، والدولة منشأ أو مصدر المسادة

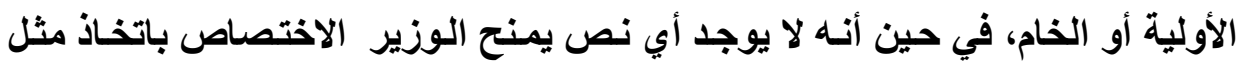

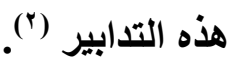

وبالإضافة إلى عيب الاختصاص فإن المنشور المتضمن لقاعدة جديدة يمكن أن يبطل أيضاً شأنه في ذلك شأن أي قرار إداري إذا شـابه أي عيب أخر، بمعنى أنها حتى إلى

(1)" que le ministre ne tenait d'aucune disposition législative le pouvoir d'édicter de telles normes".

CE 6 mars 2006, Syndicat national des enseignants et artistes, Rec.p. 107, op.cit.

(2)" que..le ministre ne s'est pas borné à interpréter les dispositions de l'article L. 441-2 du code de commerce mais a posé des règles nouvelles en imposant, pour tous les produits alimentaires périssables fabriqués ou transformés à partir de matières premières, la double mention de l'Etat de fabrication ou de transformation et de l'Etat d'origine de la matière première; que le ministre chargé de l'économie ne tient d'aucune disposition compétence pour prendre de telles mesures".

CE 21 mai 2007, Association nationale des industries alimentaires, requête $n^{\circ} 286764$.

http://www.legifrance.gouv.fr.

مجلتً البحوث القانونيتو الإقتصاديت ب اه 
وإن كان مصدر المنشور يتمتع بسلطة إصدارها، فإنهله يمكن إبطالـه إذا ثبت تعيبه بـأي عيب من العيوب التي تسمح بإلغاء القرار ('). الفرض الثاني: الخطأ في التفسير أو ترديد قاعدة مخالفة لقاعدة أعلى: ويتمثل هذا الفرض في حالة ما إذا أساء المنشور فهم معنى ونطاق النصوص التشريعية أو اللائحيـة التـي يتـولى شـرحها (؟)، أو قـام بترديــ قاعدة مخالفـة لقاعدة

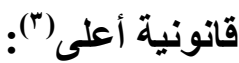

يمكن إذن إبطال المنشورات التي يشويها خطأ في التفسير بمعنى أخر تلك التي

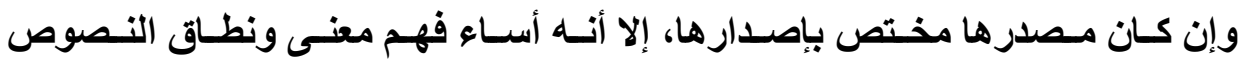
التشريعية أو اللائحية التي يتولى شرحها (؛) ، أو بعبارة أخرى أعطى تفسيراً خاطئًاً

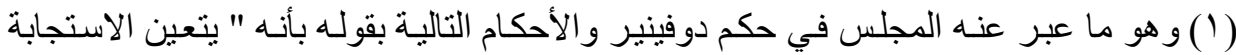

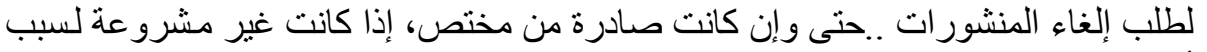

"le recours formé à leur encontre doit être accueilli.. si, alors même qu'elles ont été compétemment prises.. 'elles sont illégales pour d'autres motifs".

(2)"méconnaît le sens et la portée des dispositions législatives ou réglementaires qu'elle entendait expliciter".

(3)"réitère une règle contraire à une norme juridique supérieure"

(4)"méconnaît le sens et la portée des dispositions législatives ou réglementaires qu'elle entendait expliciter".

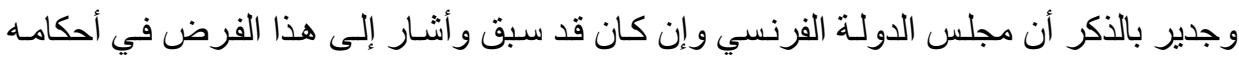

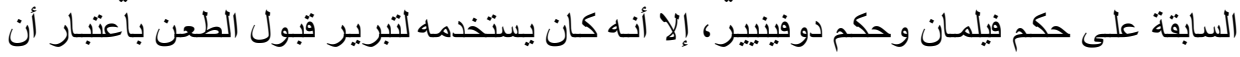

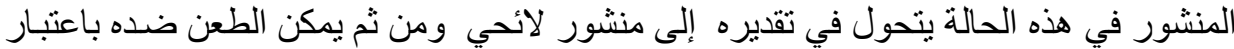

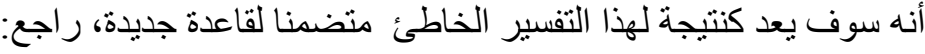
CE, sect., 20 décembre 1963, Confédération générale des vignerons du Midi, Rec. P. $648 .=$ 
للنص التشريعي أو اللائحي الذي يفترض أنسه يقوم بشرحه والتعليق عليه، ورغم أن مثل هذا الفرض كمـا هو واضـح يمكن أن يدخل في عموم الفرض السابق، ذلك أن المنشور كنتيجة للتفسير الخاطئ سيتضمن قاعدة جديدة، إلا أن مجلس الدولة الفرنسي فضل دائماً في أحكامه النص عليه على استقلال. وإذا كان حكم "دوفينير" أشـار فقط إلى التعارض contrariété مـع القواعد التشريعية واللائحية، إلا أن المجلس لم يقصر وجه عدم المشروعية المتمثل في الخطأ في التفسير أو في تطبيق القانون على ذلك الفرض حيث مده أيضاً إلى حالة التفسير

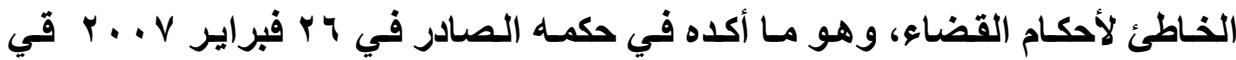
قضية الاتحاد العام للعمل Confédération général du travail ، والتي تتلخص

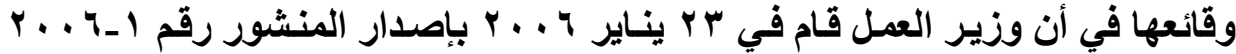

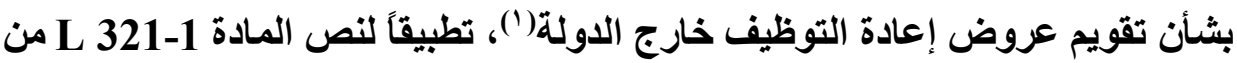
تقتين العمل، والمتعلقة بالالتزامـات المفروضـة على صـاحب العدل قبل القيـام بفصل العامل لأسباب اقتصادية licenciement pour motif économique ، والتي من بينها التزامه ـ باججراعات وضوابط معينة أوضحتها المـادة المشـار إليها أعلاه - بأن يعرض على العامل وظيفة خالية أخرى في الشركة أو أحد فروعها، وذلك دون تمييز

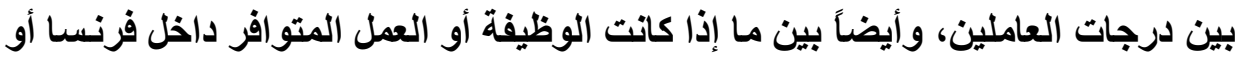
خارجها، وذلك في حالة بطبيعة الحسال مـا إذا كـان للشركة فروع في الخـارج ، إلا أن

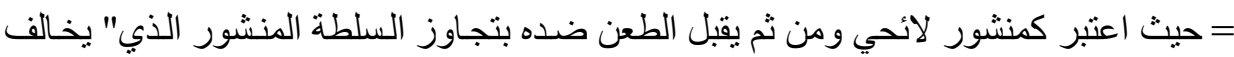

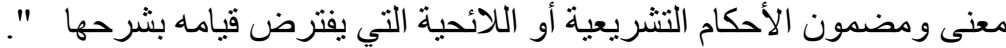
"méconnaît le sens et la portée des prescriptions législatives ou réglementaires qu'elle se propose d'expliciter"

(1) relative à l'appréciation de propositions de reclassement à l'étranger Bulletin Officiel du Ministère de l'emploi, 28 fev. 2006.

مجلت البحوث القانونيتوالإقتصاديت 
وزير العمل في المنشور المشار إليه واعتماداً على فهم خاطئ لحكم صـادر من محكمة

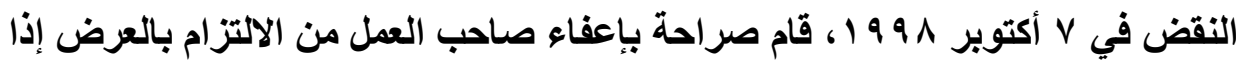

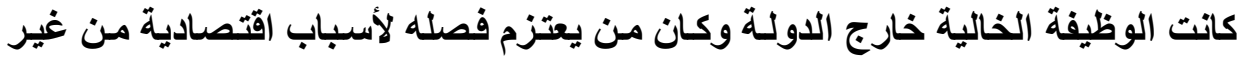

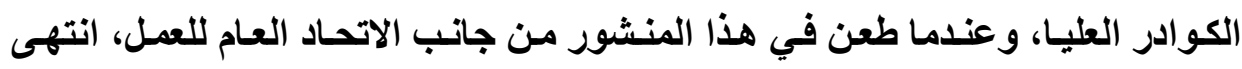
المجلس إلى إبطاله وذلك تأسيساً على أنه يناقض النص التشريعي المشار إليه أعلاه، كما أن حكم محكمة النقض الذي استند إليه الوزير صراحة لا يؤدي إلى مـا انتهى إليه

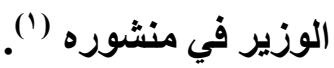

و إلى جانب الفرض السابق المتمثل في الخطأ في التفسير، فقد أضساف المجلس إلي هذا الفرض فرض أخر يتمثل في حالة قيام المنشور بترديد قاعدة مخالفة لقاعدة

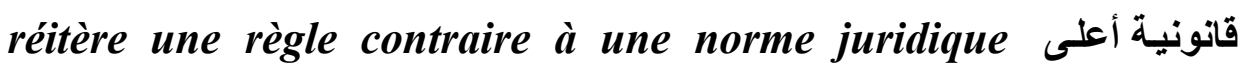
وبهذه الصياغة فقد أوضح المجلس ذلك التعبير الغامض الذي سبق وأن استخدمه بمناسبة حكمي IFOP et Villemain ، حيث كان يستخدم عبارة مخالفة

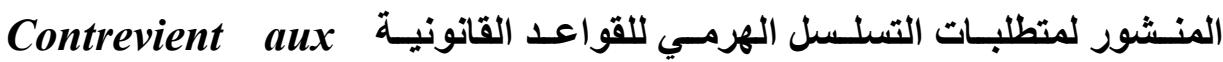
. exigences inhérentes à la hiérarchie des normes. العبارة تعطي نفس المعني إلا أن العبارة الأولى أوضح في التعبير.

ويقصد بهـذا الفرض حالـة مـا إذا كـان المنشور وإن كـان قد فسر بأمانـة interprète fidèlement

(1)"qu'une telle règle ne résulte ni des dispositions législatives précitées, ni, en tout état de cause, de l'interprétation qu'en a donnée l'arrêt de la Cour de cassation du 7 octobre 1998 ; que, par suite, l'instruction attaquée doit, dans cette mesure, être annulée".

C.E 26 février 2007 Confédération général du travail, requête $n^{\circ}$ 291625.inédit au recueil.

مجلتة البحوث القانونيت والإقتصاديت 109 
قاعدة أعلى، في هذه الحالـة فبإن العيب الذي أصساب النص الذي يتم تفسيره وفقا للمجلس ينتقل إلى المنشور ويجعله بالتالي عرضة للإلغاء.

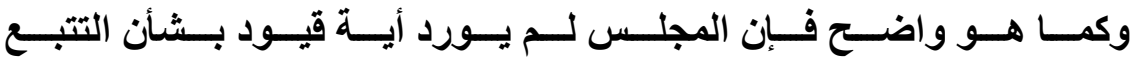
الهرمي للمشروعية، فهل معنى ذلك أنه اعترف لنفسه بصورة غير مباشرة بـالحق في مراقبة مدي إتفاق القانون الذي يستند إليه المنشور للاستور، بحيث إذا ثبت مخالفته للاستور، فإنه وإن كان لا يملك الحكم بعدم دستوريته لانفراد المجلس الدستوري كمـا نعرف بهذا الحق، إلا أنه سيملك في هذه الحالة الحق في إبطال المنشور استنادا لتلك

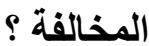

الواقع أن الإجابة عن هذا التساؤل يجب أن تتم في ضوء ما استقر عليه مجلس الاولة الفرنسي في هذا الخصوص، حيث رفض هذا الأخير باستمرار خشية الدخول في صراع أو نزاع مع السلطة التشريعية (') الاعتراف لنفسه بـالحق في مراقبة مدي اتفاق القانون الذي صدر تطبيقًا أو تنفيذا له العمل المطعون فيه أمامه للاستور، معتبراً أن الدكم بإبطال العمل المعروض عليه لمخالفة القانون المستند إليه هذا العمل للاستور معناه إعلانه بصورة غير مباشرة عدم دستورية هذا القانون وهو ما لا ياخل في نطاق اختصاصه، ولهذا يقال بأن القانون والأي يمتنع على القاضي رقابة دستوريته يقف في هذه الحالة كحاجز أو حائل بين القاضـي والاستور وهو مـا يطلق عليه الفقه نظريـة القانون الحائل أو الحاجز la théorie de la loi écran ، وهو مـا حرص مجلس

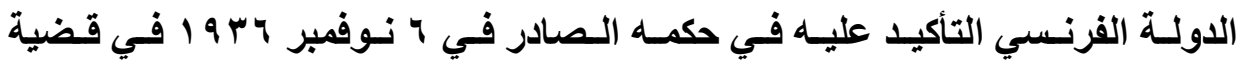
Arrighi

(1)"De crainte d'entrer en conflit avec le legislateur"

Long M., et autres, Les grands arrêts de la jurisprudence administrative, 10 ème éd., Sirey, 1993, op.cit, p. 745. 
المرسوم المطعون فيه نظرا لاتفاقه مع القانون الأي صدر تطبيقاً له رغم الدفع بمخالفة

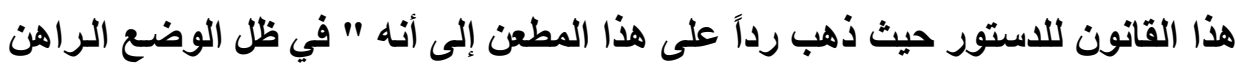

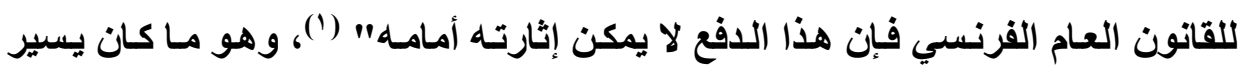
عليه أيضاً بالنسبة للمعاهدات والاتفاقيات الدولية التي تم التصديق عليها والتي تحتل

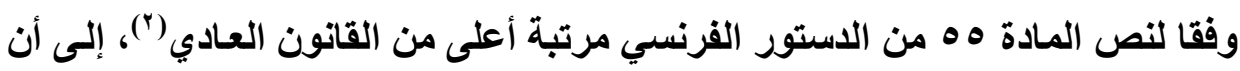

(1)" qu'en l'état actuel du droit public français, ce moyen n'est pas de nature à être discuté devant le Conseil d'État statuant au contentieux".

CE Sect., 6 novembre 1936, Arrighi, Rec. p. $966 ;$ S. 1937.III. p. 33, concl. Latournerie, note Mestre; DP 1938, III, p. 1 concl. Latournerie, note Eisenmann.

ومن أحكامه الصادرة بعد حكم "دوفينيير" Duvignières سالف الذكر بمكن أن نذكر : Buillardec CE, 5 janvier 2005, Deprez et Baillard, Rec. p. 1.

(2)CE. Sect. ler mars 1968, Syndicat général des fabricants de semoules de France, Rec. p. 149, AJDA 1968, p. 235, concl. Questiaux

حيث فض في هذا الحكم التحقق من مدى مطابقة القانون للمعاهدات التي تم التصديق عليها،

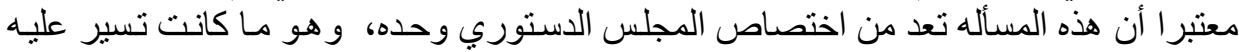

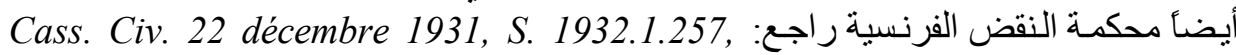
في concl. Matter, note Niboyet.

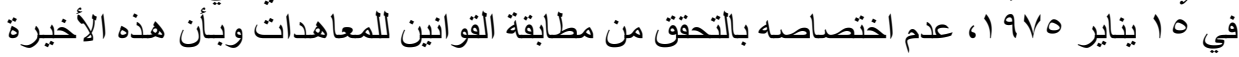

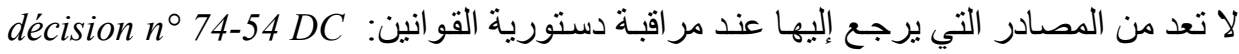
du 15 janvier 1975,Rec. p. 19, AJDA 1975, p. 134, note Rivero, RDP 1975, p. نطا 185, comm.Favoreu et Philip نظريـة القانون الحاجز بالنسبة للمعاهدات: Cass. Ch. mixte, 24 mai 1975, Société des cafés Jacques Vabre, D. 1975.497, cocl. Touffait, AJDA 1975, p. 567, note Boulouis

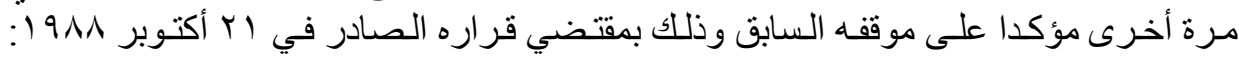
Cons. Constit., 21 octobre 1988, Ass. nat. Val d'Oise, 5e circ., R.p. 183, RFDA . 1988, 908, note genevois, AJDA 1989, p. 128, note Wachsmann. المجلس بمقتضى حكم نيكولو Nicolo كما سنرى حالا العدول شأن المعاهدات عن تللك النظرية. 
قام بالتخلي عن هذه النظرية بالنسبة للمعاهدات بمقتضى حكمه الصادر في · ب أكتوبر

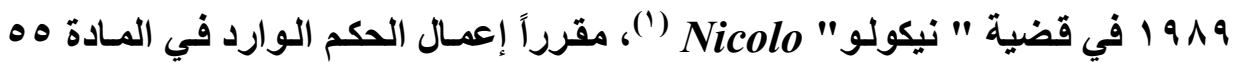

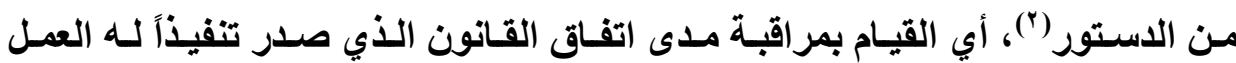
المطعون فيـه مـع المعاهـات الدوليـة التـي تـم التصديق عليهـا ، بحيث إذا ثبـت لـهـ التعارض، فإن العيب الأي شاب القانون في هذه الحالة ينسحب إلى العمل المطعون فيه ويصبح بالتالي محلاً للإلغاء.

وهو ما سار عليه مجلس الدولة الفرنسي عند فحصه لمشروعية المنشورات، فقي قضية Union française pour la cohésion nationale السابق الإشـارة إليها والتي استند فيها الطاعن في مطالبته إلغاء منشور وزير التعليم والبحث العلمي

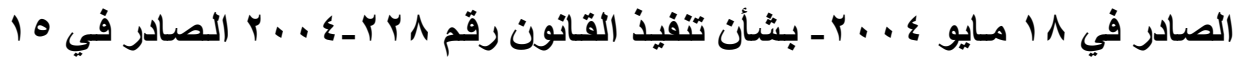
مارس ؛ . . ب المتعلق بتظيم- وفقاً لمبدأ العلمانية ـ حمل الشارات وارتداء الملابس التي تظهر الانتماء الايني في المدارس والمعاهد الحكومية- إلى مناقضة هذا المنشور

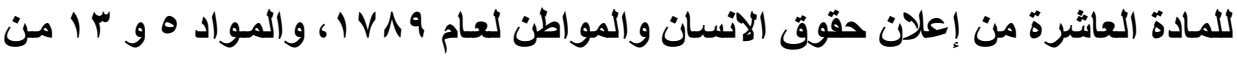

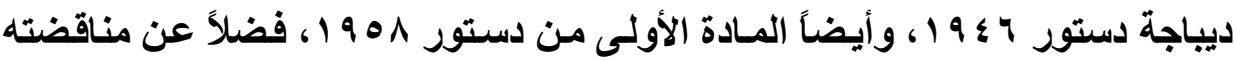

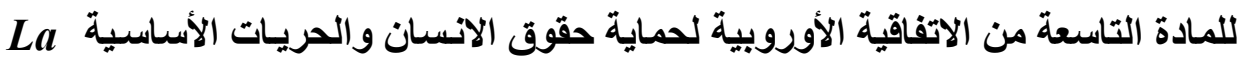
convention européenne de sauvegarde des droits de l'homme et des libertés fondamentales ، والمـادة ^1 1 من العهد الدولي للحقوق المدنية Le pacte international des droits civils et politiques, والسياسية

(1) CE. 20 octobre 1989 , Nicolo, Rec. p. 190, concl. Frydman, RFDA 1989, p. 812, p. 824, note Genevoiis, p. 993, note Favoreu, p. 1000, note Dubouis, RDP 1990, p. 801, note Touchard.

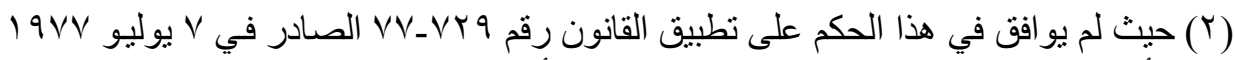

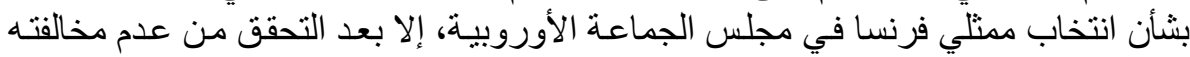

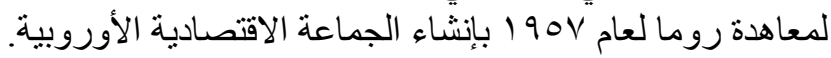


فبعد أن قرر المجلس قبول الطعن استناداً إلى الطـابع الآمـر لهذا المنشور،

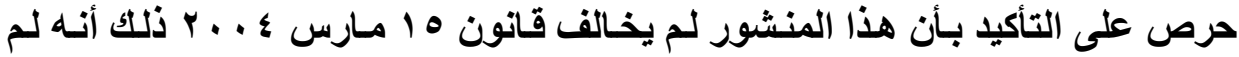
يفعل أكثر من ترديد الحكم الوارد في هذا القانون والذي يمنع التلاميذ في المعاهد

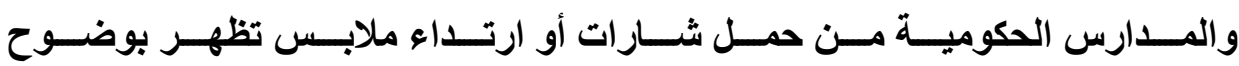
ostensiblement القيام بذلك معناه مراقبته في الحقيقة لاستورية القانون الأي استتد إليه المنشور وهو

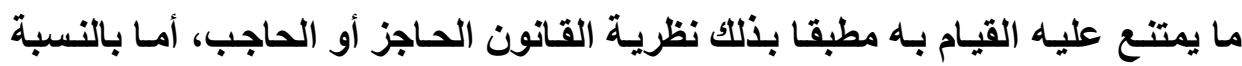
للوجه الثاني من أوجه الطعن المتمثل في مخالفة المنشور لبعض القواعد الدولية كـان حريصا على تفحص هذا الوجها حيث انتهى إلى رفض الطعن وذلك استناداً إلى أن المنشور لم يخالف معنى ومضمون القانون الصادر تطبيقا له، كما أنه لم يخالف أيا من القواعد الدولية السابق الإشارة إليها (').

(1)" Considérant que la circulaire attaquée a été prise en application de la loi du 15 mars 2004 dont,... elle s'est bornée à rappeler et expliciter les termes ; que, par suite, les moyens tirés de la méconnaissance des dispositions de l'article 10 de la Déclaration des droits de l'homme et du citoyen de 1789, des articles 5 et 13 du préambule de la Constitution de 1946 et de l'article ler de la Constitution du 4 octobre 1958 sont inopérants ...Considérant que les dispositions de la circulaire attaquée ne méconnaissent ni les stipulations de l'article 9 de la convention européenne de sauvegarde des droits de l'homme et des libertés fondamentales, ni celles de l'article 18 du pacte international des droits civils et politiques.."

CE, 8 octobre 2004, Union française pour la cohésion nationale, Rec.p.367, AJDA 2005, p. 43, note Rolin, RFDA 2004, p.977, concl. Keller, JCPA 2004, 1849, note Tawil.op.cit.

مجلة البحوث القانونيت والإقتصاديت 17 
غير أنه إذا كانت القاعدة أن دور القاضي في حالة الطعن الموجه ضد الأعمال

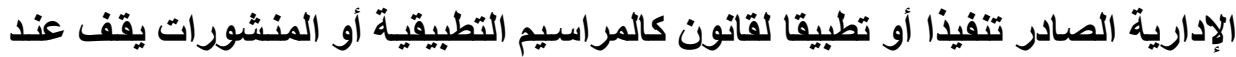

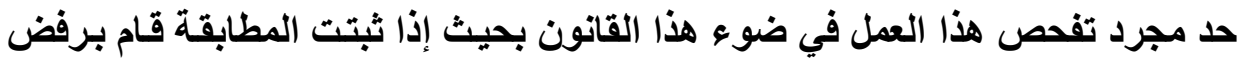

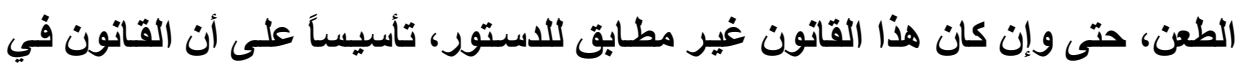

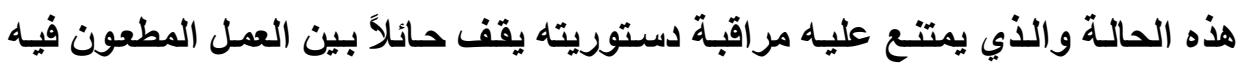
والاستور، بعبارة أخرى فإن وجود القانون بين الاستور والعمل الإداري يحول دون

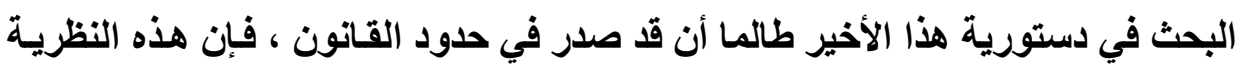

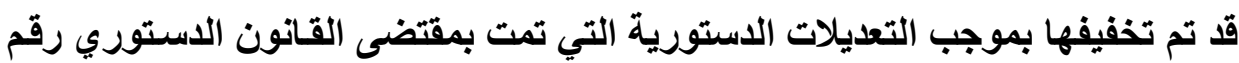

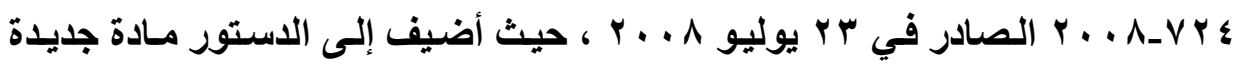

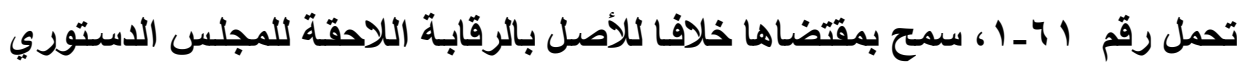

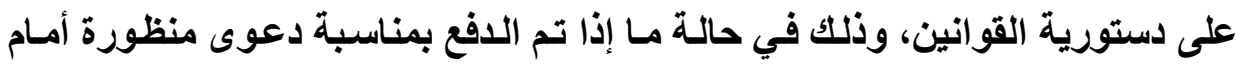

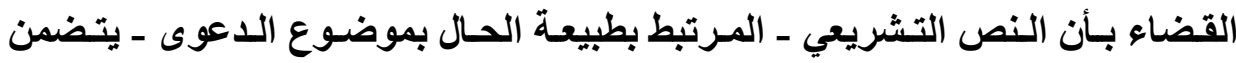

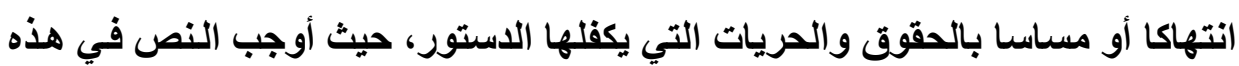

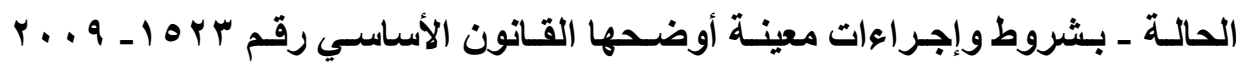

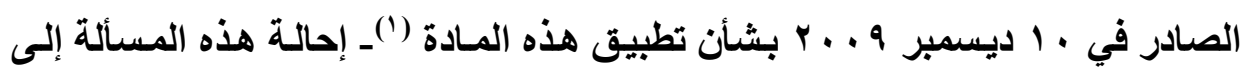
المجلس الاستوري من جاتب سواء مجلس الدولـة أو محكمة النقض حسب الأحسوال، على أن يتم الفصل فيها خلال

(1)Loi organique $n^{\circ} 2009-1523$ du 10 décembre 2009 relative à l'application de l'article 61-1 de la Constitution, J.O 11 décembre 2009 page 21379.

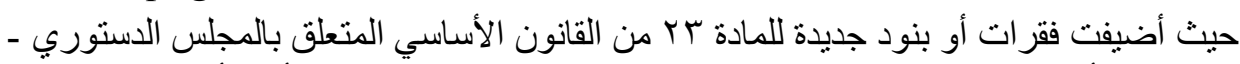

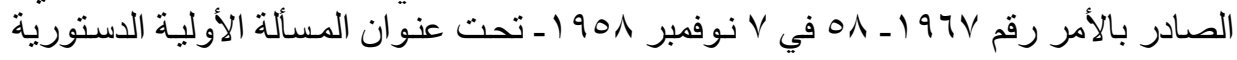
De la question prioritaire de constitutionnalité.

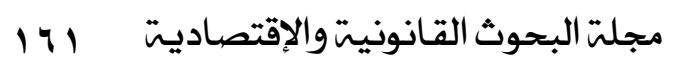


أجل معين (')،دده القانون الأساسي المشار إليه بثلاثة أشهر، وإن كـان البعض يرى أن هذا الميعاد لا يعدو مجرد ميعادا تنظيميا نظراً لعدم وجود أية جزاءات على

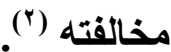

غير أنه إذا كاتت تعديلات 1 . . . من شأنها التخفيف من نظرية القانون الحاجز بشأن فحص الدستورية بالنسبة للمنشورات حيث أصبح مـن الممكن إثـارة مسألة دستورية القانون الذي يتولى المنشور تفسيره، بحيث إذا ثبت عدم دستوريته قضى المجلس الاستوري بإلغائه(")، الأمر ينعكس بأثره على المنشور الصادر بناء عليه، ذلك أنه في هذه الحالة يعد صادرا على غير أساس من الثرعية،بعبارة أخرى فإن القضاء

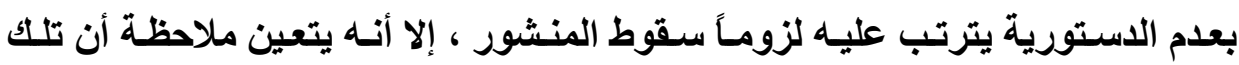

$$
\text { ويجري نص هذه المادة باللغة الفرنسية على النحو التالي: }
$$

"Lorsque, à l'occasion d'une instance en cours devant une juridiction, il est soutenu qu'une disposition législative porte atteinte aux droits et libertés que la Constitution garantit, le Conseil constitutionnel peut être saisi de cette question sur renvoi du Conseil d'Etat ou de la Cour de cassation qui se prononce dans un délai déterminé "

$$
\begin{aligned}
& \text { (Y) د. صلاح الدين فوزي، المجلس الدستوري الفرنسي، الطبعة الثنانية، دار النهضية العربيـة، }
\end{aligned}
$$

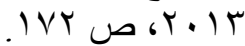

$$
\begin{aligned}
& \text { ومن تطبيقات مجلس الدولة الفرنسي لهذا النص راجع: }
\end{aligned}
$$

CE, 14 avril 2010, Union des familles en Europe AJDA 2010, p. 1013, concl. Courrèges, CE, 14 avril 2010, requête numéro 336753, Labane

http://www.conseil-etat.fr/

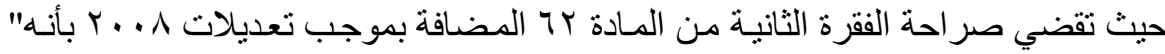

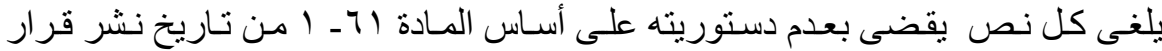

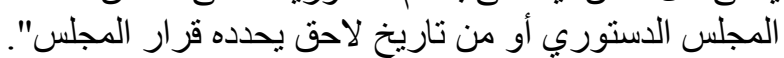

"Une disposition déclarée inconstitutionnelle sur le fondement de l'article 61-1 est abrogée à compter de la publication de la décision du Conseil constitutionnel ou d'une date ultérieure fixée par cette décision". 
الرقابة لا يملك القاضي تحريكها من تلقاء نفسه(')، و إنما لابد أن تتم من خلال دفع يتم الدفع به من جاتب الخصوم باجرزاءات وشكليات معينـة أخصها وجوب أن يقدم بشكل

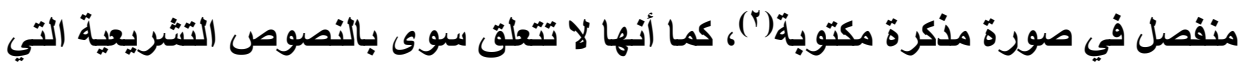
تتضمن انتهاكاً للحقوق والحريات التي كفلها الاستور، أمسا في خـارج هذا الإطسار فـإن فحص مشروعية المنشور المطعون فيها تطبيقا لنظريـة القانون الحاجز، سوف تقف فئف عند حد القانون الذي صدر المنشور تفسيراً لـه حتى وإن كـان هذا القـانون مناقضاً

( ) و إن كان يمكن إثارته من جانب الخصوم لأول مرة أمام محكمة الاستئناف.

" Un tel moyen peut être soulevé pour la première fois en cause d'appel. Il ne peut être relevé d'office."

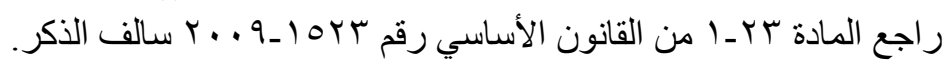

(2) "présenté dans un écrit distinct et motivé".

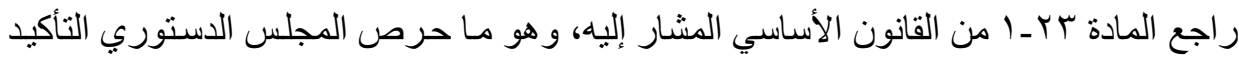

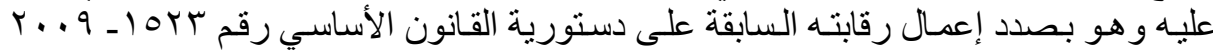

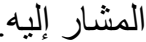

C.C., Décision $n^{\circ}$ 2009-595 DC du 03 décembre 2009.

http://www.conseil-constitutionnel.fr/

$$
\text { لمزيد من التفاصيل بشأن تلاك الرقابة راجع: }
$$

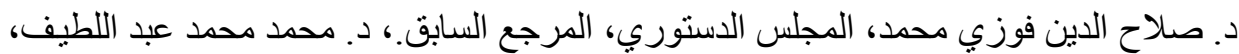

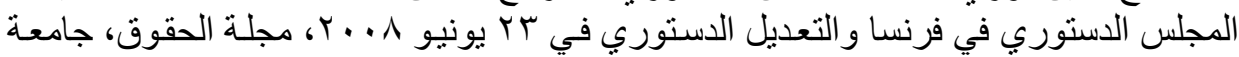

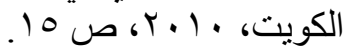

Benetti J., La genèse de la réforme, AJDA 2010 p. 74 ;Roblot-Troizier A., La question prioritaire de constitutionnalité devant les juridictions ordinaires : entre méfiance et prudence,, AJDA 2010, p. 80; Le Prado D., La question prioritaire de constitutionnalité vue par un avocat, AJDA, p. 94; Verpeaux M., Le Conseil constitutionnel juge de la question prioritaire de constitutionnalité, AJDA 2010 p. 88.

مجلتّ البحوث القانونيت والإقتصاديت س ا 
ولا شك أن نظرية القانون الحاجز أو الحائل تتفق مع تبني الدساتير الفرنسية ـ

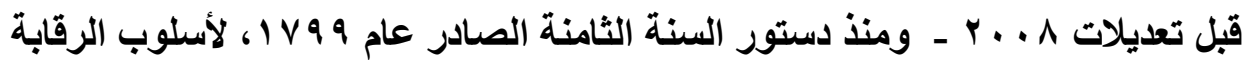

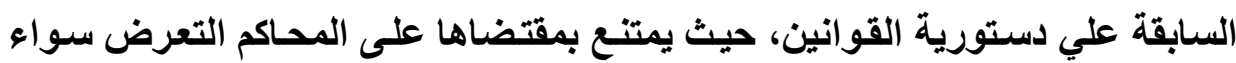
بصورة مباثرة أو غير مباشرة لاستورية القو انين بعد صدورها، فالقانون بعد الاصدار ينجو من أية مناز عة في دستوريته. أما في مصر فلا مكان في الحقيقة لتلك النظرية، ذلك أن القاعدة في تحريك رقابة الاستورية لدينا أنها لاحقة، كما أنها لا تقف عند حد القوانين وإنما تمتـ إلى فلى

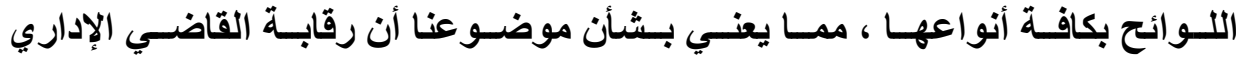
لمشروعية المنثور إذا ما قبل الطعن ضده لن تقف عند حد القانون الذي يتم تفسيره أو

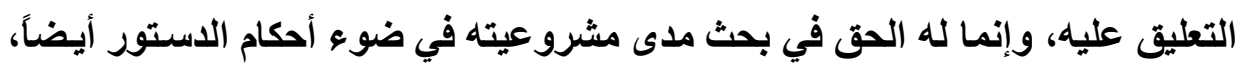

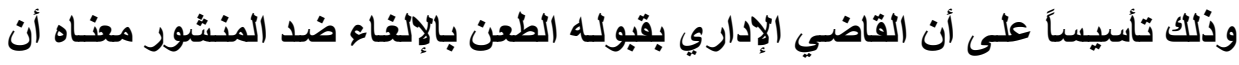
مقومـات القرار الإداري قد تو افرت لـه، ونظرا لعموميته وتجريده فإنـه سيعد بمثابـة لائحة ومن ثم يسري عليه ما يسري على اللوائح من أحكام. 


\section{المبحث الثالث}

\section{الإصلاح التنظيسمي لنظام نشر المنشورات}

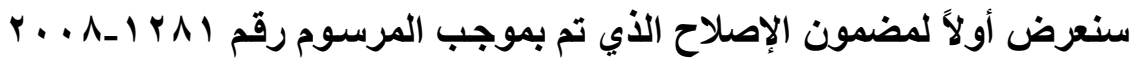

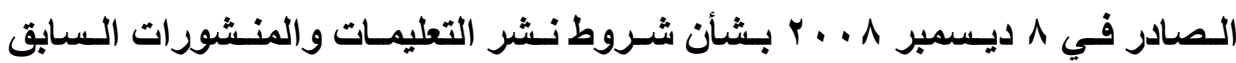
الإشـارة إليه " المطلب الأول "، ثم نعقبه ببيان موقف القاضسي الإداري منـه " المطلب

\section{الإطلب الأول

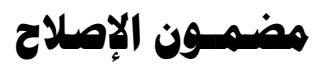

قدمنا أن المـادة التاسـعة مسن القـانون رقـم VA_VOr الـصـادر في I يوليو

19V^ بــأن الاطـلاع على الوثـائق الإداريـة ـ والتي أصسبحت المسادة السـابعة بعد

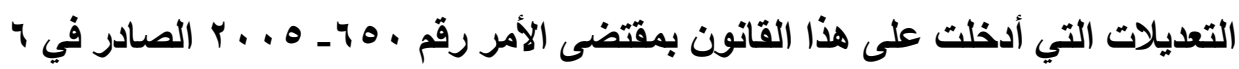

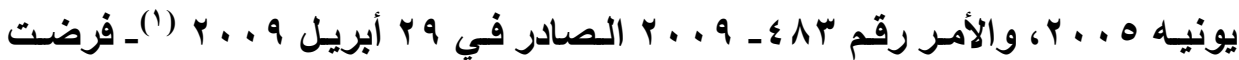
على الجهات الإداريـة نشر التوجيهات والمنشورات والملاحظات والإجابـات الوزاريـة

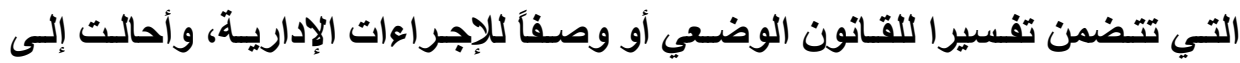
commission رسـوم يصدر بعـد أخـذ رأي لجنـة الإطـلاع على الوثـائق الإداريـة d'accès aux documents administratifs (CADA)

(1)L'ordonnance $n^{\circ} 2005-650$ du 6 juin 2005,J.O.7 juin 2005, et l'ordonnance $n^{\circ} 2009-483$ du 29 avril 2009.

http://www.legifrance.gouv.fr

مجلتّ البحوث القانونيت والإقتصاديت 19 
décret en Conseil d'Etat

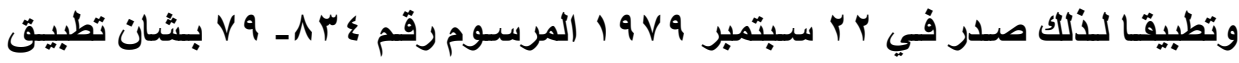
تلـك المسادة، والـذي حل محلـه بمناسـبة التعـيلات التـي أدخلت علـى هـذا القـانون

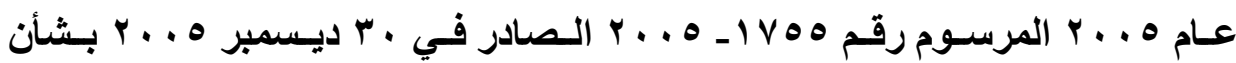

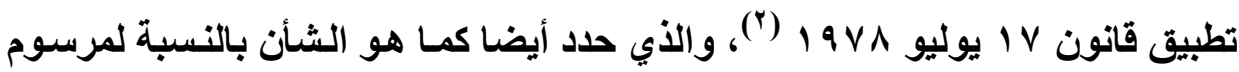
9 V 9

Bulletin officiel عن الإدارة المركزية للاولة يجب نشرها في نشره رسمية وزارية تصدر بصورة دوريـة كل ثلاثـة أشـهر على الأقل، وبالنسبة لتلـ الصادرة عن الأشخاص العامة المحلية و المرفقية يتم النشر سواء في نشرة رسمية تصدر بصورة دوريـة كل ثلاثة أشـهر، أو نسخها في غضون ثلاثة أثـهر في سجل يوضـع تعت تصرف الجمهور (")، كذلك أيضاً كمـا كـان منـصوصا عليهه في المـادة

(1) ويجري نص المادة التاسعة باللغة الفرنسية قبل تعديلها عام ه . . ب على النحو الآتي:

" Font l'objet d'une publication régulière : 1-Les directives, instructions, circulaires, notes et réponses ministérielles qui comportent une interprétation $d u$ droit positif ou une description des procédures administratives ; 2- La signalisation des documents administratifs. Un décret en Conseil d'Etat pris après avis de la commission d'accès aux documents administratifs précisera les modalités d'application du présent article".

(2) Décret $n^{\circ}$ 2005-1755 du 30 décembre 2005 relatif à la liberté d'accès aux documents administratifs, pris pour l'application de la loi no 78-753 du 17 juillet 1978.

http://www.legifrance.gouv.fr

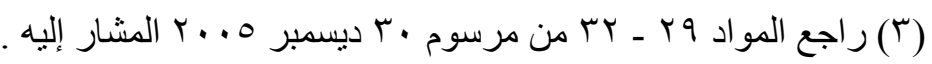


السادسة من مرسوم 9 9 9 1، فقد فرضت المادة بr من مرسوم ه . . ب التزاما بأن يتم النشر خلال الأربعة أشهر التالية لصدور الأعمال المشار إليها(')

غير أن الواقع أثبث أن جهة الإدارة لم تعر هذا الإلزام اهتمامسا، وهو مـا حرص

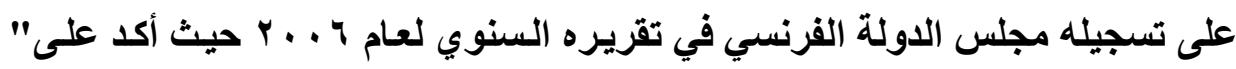
أن نشر المنشورات ما زال من الناحية الواقعية متروكاً لمطلق تقدير الوزراء، فبعضها يتم نشره في الجريدة الرسمية للجمهورية الفرنسية، وبعضها يتم نشره في النشرات

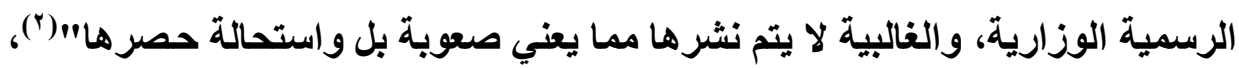

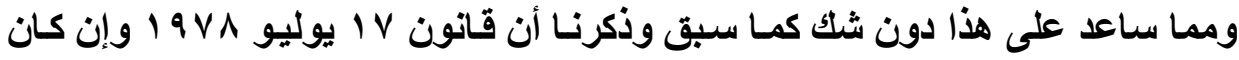
قد فرض النشر إلا أنه لم ينص على أي جزاء يمكن تطبيقه حسل الاخـلال بهذا الالزام ، فعدم النص على جزاء جعل هذا الالزام كما يقول الأستاذ "كوبي" Koubi دون فائدة

(1)"La publication prévue aux articles 29 à 32 intervient dans les quatre mois suivant la date du document."

(2)" La publicité des circulaires et instructions est, en fait, souvent laissée à la discrétion des ministères : certaines font l'objet d'une publication au Journal officiel de la République française, d'autres figurent aux Bulletins officiels des ministères ; les dernières, nombreuses, ne font l'objet d'aucune publication. Leur recensement est par conséquent très difficile, voire impossible".

rapport de 2006, La Documentation française, Paris 2006, p. 331.

و هو ما حرصت أيضا منظمة ال OCDE التأكيد عليه في تقرير ها لعام ع ... ب بشأن الاصلاح

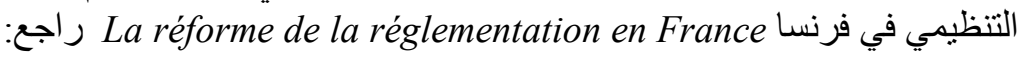

Rapport public du Conseil d'Etat de 2006, Sécurité juridique et complexité du droit - La Documentation française, Paris 2006, p. 331 
أو لا طائل منه (')، صحيح أن مرسوم • ب ديسمبر ه . . ب السابق الإشـارة إليه حاول par إخال بعض التحسينات حيث سمح بإمكانية القيام بنشر المنشورات إلكترونيا facultative إلا أن هذا التحسين فضلاً عن كونـه اختياريـ voie électronique

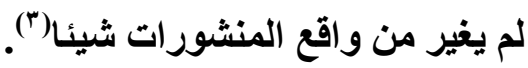

ولهذا كان طبيعيا نظراً للأهمية التي تحتلها المنشورات في الحياة الإداريـة، أن يتم التفكير في إيجاد وسيلة يمكن من خلالها إجبار جهة الإدارة على التصرف في وضـح النهار بـأن تكون جميع منشور اتها بغض النظر عن طبيعتهـا معلنـة ومعلومـة للجميع إعمالاً للحق في العلم أو الاطلاع ذلك الحق الذي اعترف بـه كمـا قدمنا للأفراد مـع نهايـة الثمانيـات والذي يفرض الكشف عمـا تحت يــ جهـة الإدارة مـن منشورات وتعليمات تتصرف في ضوئها دون أن تكون معلومة للجميع، والتي أطلق عليها مجلس الدولة الفرنسي في تقريره السابق الإشارة إلية القانون المخبأ droit souterrain.

(1)" L'obligation de publicité des circulaires reste vaine" Koubi G., Les circulaires administratives, op.cit., p. 302.

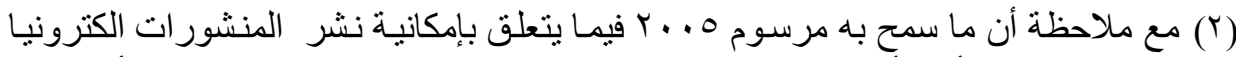

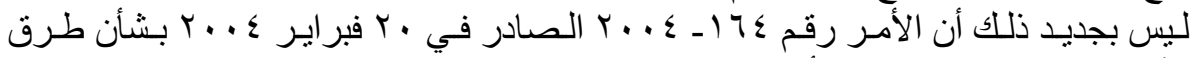

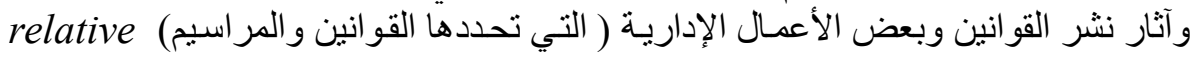
aux modalités et effets de publication des lois et de certains actes administratifs

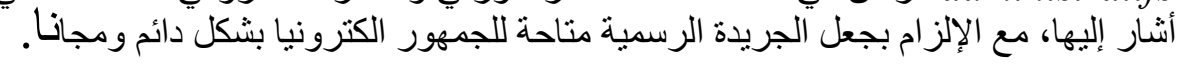

Article 3" La publication des actes mentionnés à l'article 2 est assurée, le même jour, dans des conditions de nature à garantir leur authenticité, sur papier et sous forme électronique. Le Journal officiel de la République française est mis à la disposition du public sous forme électronique de manière permanente et gratuite".

(2)Combeau P. et Formery S., Le décret du 8 décembre 2008 : un nouvel éclairage sur le « droit souterrain » ?, AJDA 2009, p. 811. 
وقد جـاعت المبـادرة مـن جانب المكومـة المركزيـة حيث قـام رئسيس الـوزراء

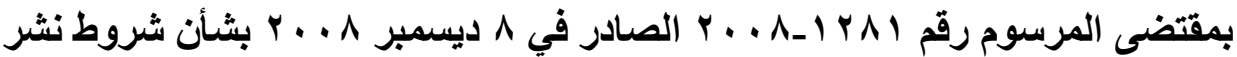

التعليمات والمنشورات(')،بفرض نظام جديد على الإدارة المركزيـة للاولة بشأن نشر

المنشورات الوزارية مقترن بجزاء فعال، فوفقاً للفقرة الأولى من المادة الأولى من هذا

المرسوم فإن المنشورات الموجهة من الوزراء إلى أجهزة ومؤسسات الدولة يجب أن

تكون متاحة للجمهور على موقع على شبكة الانترنت يتبع رئيس الوزراء(")، على أن آن

يتم تصنيفها وفهرستها بصورة يسهل معها الرجوع إليها"(ا)، وقد وضعت الفقرة الثانية

(1)Décret $n^{\circ} 2008-1281$ du 8 décembre 2008 relatif aux conditions de publication des instructions et circulaires, J.O. 10 déc. 2008; AJDA 2008, p.2309.

www. circulaires.gouv.fr.

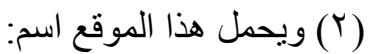

(3) Article ler alinéa 1:" Les circulaires et instructions adressées par les ministres aux services et établissements de l'Etat sont tenues à la disposition du public sur un site internet relevant du Premier ministre Elles sont classées et répertoriées de manière à faciliter leur consultation".

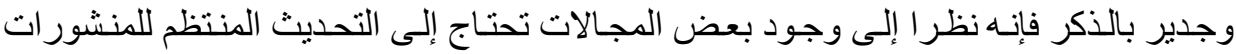

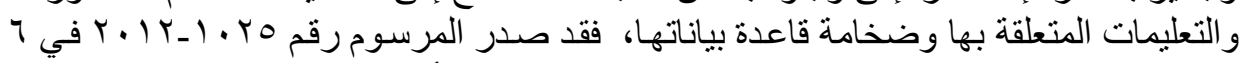

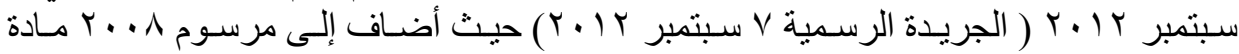

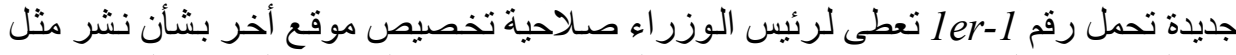

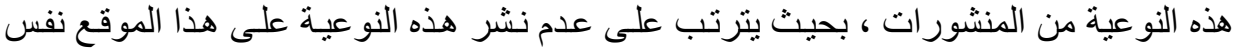

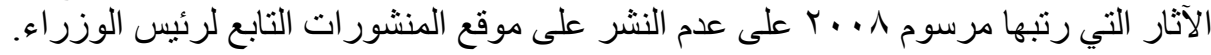
Art. 1er-1. "Un arrêté du Premier ministre peut prévoir que, pour les circulaires et instructions intervenant dans certains domaines marqués par un besoin régulier de mise à jour portant sur un nombre important de données, la mise à disposition sur un site internet autre que celui qui est mentionné à l'article ler produit les mêmes effets que la mise à disposition sur ce site..." 
من نفس المادة جزاء لهذا الإلزام، حيث قررت صراحة عدم تطبيق أي منشور لا يتم نشره على هذا الموقع، وزيادة في التأكيا أضافت بأنه ولا يمكن في هذه الحالة للجهات الإدارية التمسك بها في مواجهة المتعاملين معها (') وكمـا هو واضـح فـإن مـا فرضـه هذا المرسـوم يقتصر فقط على المنشورات الوزاريـة ممـا يعنـي خروج كافة المنشورات الصادرة مـن جهـات أخرى كالمحـافظين وممثلي الأشخاص المعنوية المحلية من إطار أحكام هذا المرسوم، ورغم أن النص لم يشر إلى منشورات رئيس الوزراء إلا أن المنطق يقضي بوجوب إخضاعها لنفس أحكام المنشورات الوزارية بعبارة أخرى فإن إخضاعها لهذا الإلزام يعد أمراً بـديهياً، إذ كيف بمكن لموقع الكتروني ينهض به رئيس الوزراء ألا يشير للمنشورات الصادرة عن هذا الأخير (י). وقد حددت الفقرة الأولى من المـادة الثانية تـاريخ الأول من مـايو 9 . . ب ب لبدء سريان هذا الإلزام وترتيب مثل هذا الجزاء (")، ولإجبار الجهات الخاضعة لأحكام هذا المرسوم على القيام بمراجعة وتنظيم المنشورات السابقة على صدور هذا المرسوم لتحديد ما تحتاجه منها وما لم تعد في حاجة إليه، وتحقيقا للعلم الفعلي- وهذا هو الأهم - بهذه المنشورات الأي أطلق عليها مجلس الدولة في تقريره السابق الإشـارة إليه "القانون المخبأ " droit souterrain ، لم يشأ المرسوم أن يقصر هذا الإلزام على

(1) Article ler alinéa 2:" Une circulaire ou une instruction qui ne figure pas sur le site mentionné au précédent alinéa n'est pas applicable. Les services ne peuvent en aucun cas s'en prévaloir à l'égard des administrés".

(2) Combeau P. et Formery S., Le décret du 8 décembre 2008 : un nouvel éclairage sur le "droit souterrain »?, AJDA 2009, p. 813.

(3) Article 2 alinéa 1: "L'article ler prend effet à compter du ler mai 2009".

IV . مجلة البحوث القانونيت والإقتصاديت 
المنشورات الصادرة اعتباراً من الأول من مايو 9 . . ب ، و إنما مد هذا الإلزام أيضا إلى

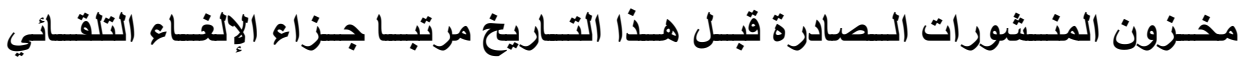
l'abrogation automatique التي لا يتم نشرها في هذا التاريخ على الموقع المخصص للمنشورات التابع لرئيس (الوزراء (1) (1) وتحقيقا للتناغم بين ما فرضه مرسوم ^ . . ب وبين مـا سبق وأن فرضـه قانون

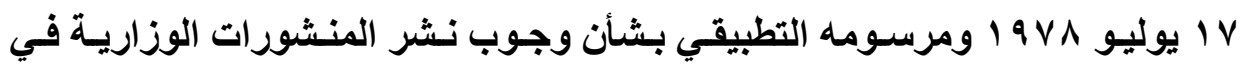
النشرة الرسـية الوزاريـة على النحو السـالف بيانـه، فقد أوردت الفقرة الأخيرة مـن

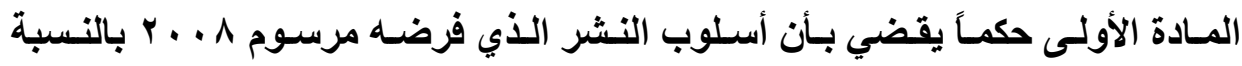

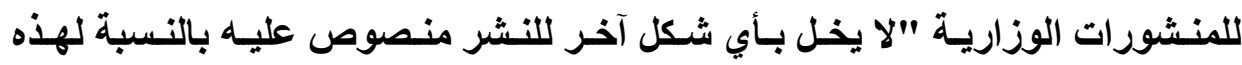

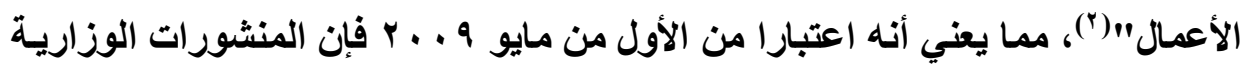

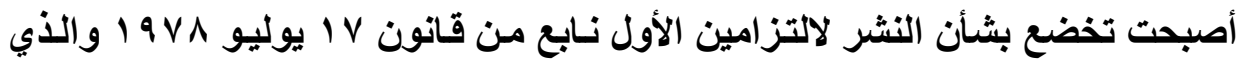

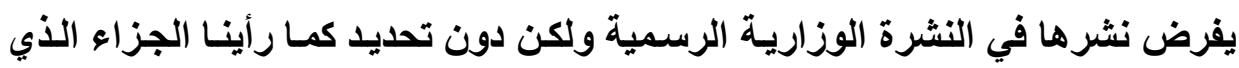
يمكن توقيعه في حالة عدم الالتزام، والثاني ينبع من مرسوم ^ ديسمبر ^ ـ . . ب والذي فرض نشرها أيضاً على موقع الكتروني يتبع رئيس الوزراء مع توقيع جزاء كمـا رأينا يرتب تلقائياً في حالة الإخلال به.

(1) Art. 2. alinéa 2 :" Les circulaires et instructions déjà signées sont réputées abrogées si elles ne sont pas reprises sur le site mentionné à l'article ler.

(2) " Cette publicité se fait sans préjudice des autres formes de publication éventuellement applicables à ces actes".

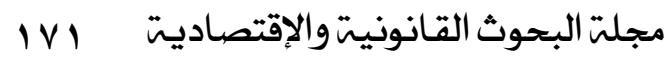




\section{المطلب الثاني}

\section{هوقف القضاء الإداري}

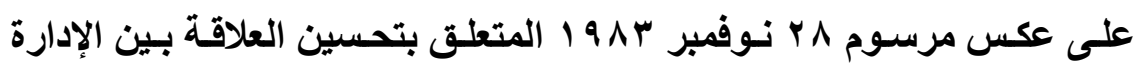
والجمهور السابق الإشارة إليه، والذي كان يعترف صراحة للأفر اد بـالحق في التمسك

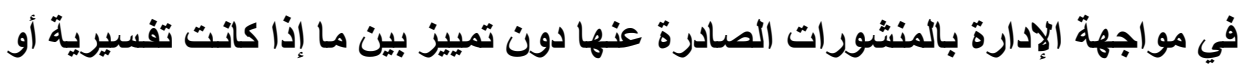
لاتحية والذي تجاهل مجلس الدولة الفرنسي على النحو السالف بيانه وجوده إلى أن تم

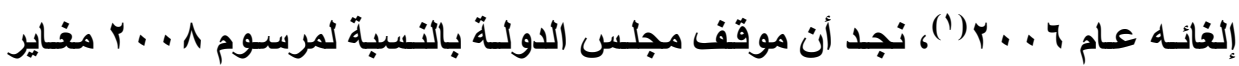
تمامـا حيث حرص على تطبيق أحكامسه بكل دقة، سواء فيمـا يتعلق بالإلغـاء التلقائي للمنشورات السابقة على الأول من مايو 9 ـ . r والتي لم يتم نشرها في التاريخ المشار إليه على الموقع الاكتروني المخصص للمنشورات www.circulaires.gouv.fr أو فيما يتعلق بعدم إمكانية تطبيق أو الاحتجاج بالمنشورات الصادرة بعد هذا التاريخ ولم يتم نشرها على هذا الموقع.

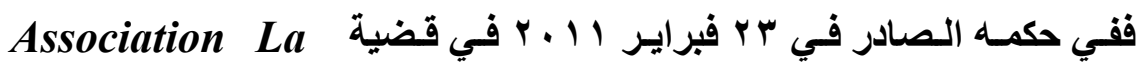
CIMADE

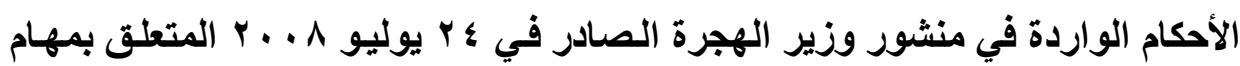
centres d'accueil pour demandeurs مراكز استقبال طالبي اللجوء لفرنسا d'asile أنه غير ذات موضوع dépourvue d'objet، ذلك أن الطعن قد انصب في الحقيقة على منشور أصبح لاغياً تلقائياً في الأول من مـايو 9 . . ب لعدم نشره على الموقع 
الاكتروني حتى هذا التاريخ، وهو التاريخ الذي حدده مرسوم ^ . . ب لنفاذ الجزاء الذي

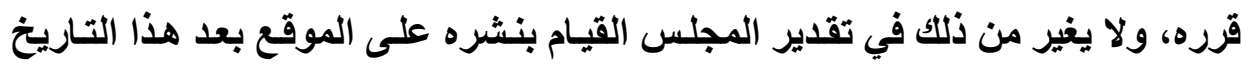
ذلك أن النثر في هذه الحالة قد انصب على منثور ملفي (')

(1)CE 23 févr. 2011, Association La CIMADE; AJDA 2011. 415; D. 2011. 758 ; RDSS 2011. 514 :

" que la circulaire du 24 juillet 2008 du ministre de l'immigration. $n^{\prime} a v a i t$ pas été reprise, à la date du $1^{\text {er }}$ mai 2009, sur le site... que, par suite, cette circulaire doit, conformément à l'article 2 du même décret, être regardée comme abrogée à compter du $1^{e r}$ mai 2009 ; que sa mise en ligne sur ce même site à une date postérieure au $1^{e r}$ mai 2009 n'a pas eu pour effet de la remettre en vigueur; que, par suite, la requête de l'ASSOCIATION LA CIMADE...tend à l'annulation de dispositions qui étaient déjà abrogées à la date où elle a été introduite..(est rejetée)".

$$
\text { راجع أيضاً: }
$$

CE 16 avr. 2010, Azelvandre, AJDA 2010.p 1726; CE 27 mars 2013, Association des professionnels de la location meublée, req. $n^{\circ} 360248$, Inédit au Recueil Lebon: "Considérant qu'il ressort des pièces du dossier que la circulaire du 22 mars 2006 sur l'application des mesures relatives au changement d'usage des locaux d'habitation n'avait pas été reprise, à la date du ler mai 2009, sur le site internet crée en application des dispositions de l'article ler du décret du 8 décembre ...que, par suite, cette circulaire doit.., être regardée comme abrogée à compter du ler mai 2009 ; qu'ainsi la demande tendant à son abrogation, .., était dépourvue d'objet ; que l'association n'est par suite pas fondée à soutenir qu'en s'abstenant de faire droit à cette demande le ministre aurait pris une décision illégale ... ...qu'il résulte de ce qui précède, sans qu'il soit besoin d'examiner les moyens tirés de l'illégalité de la circulaire du 22 mars 2006, que la requête de l'association des professionnels de la location meublée doit être rejetée".

http://www.dalloz.fr

مجلتً البحوث القانونيتوالإقتصاديت 
وإن كان المجلس في بعض أحكامه اللاحقة قد أظهر قبوله الطعن ضد المنشور

بل وحكم بإبطاله رغم كونـه ملغيـاً أو غير مطبق لعدم نشره على الموقع الاكترونسي،

وذلك إذا كـان قد تم بالفعل البدء في تطبيقه أو تنفيذه (')، وهو مـا يعد أمراً منطقيا

لإبطال مارتبه من آثار إذا كان بطبيعة الحال غير مشروع.

كما حرص أيضا على التأكيا بأنه حتى يمكن التمسك أو الاحتجاج بالمنشورات

الوزاريـة الـصادرة بعـ الأول مـن مسايو 9 . . ب في مواجهـة المتعـاملين مـع الجهـات

الإدارية فانه يتعين أن يكون قد تم نشرها في النشرة الرسمية الوزاريـة تطبيقاً لنص

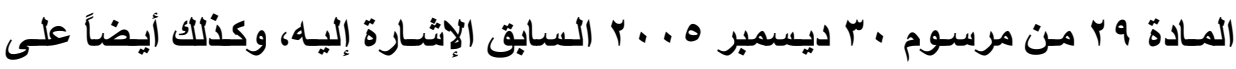

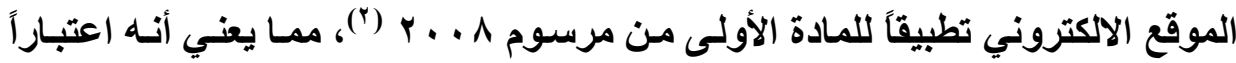

(1)CE 7 avr. 2011, Association SOS racisme - Touche pas à mon pote, AJDA 2011.p. 1438, note Bailleul D.

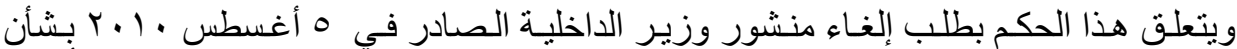

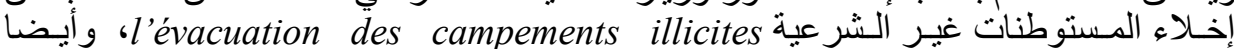

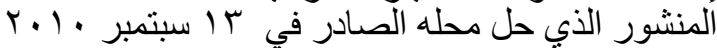

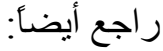

CE ass. 26 oct. 2011, Association pour la promotion de l'image, AJDA 2012 .p. 35, chron. Guyomar M. et Domino X.

CE 16 apr. 2012, COMITE HARKIS ET VERITE, $n^{\circ} 335140,335141$ : " si ces circulaires doivent être regardées comme abrogées à compter du ler mai 2009, elles ont reçu application avant cette date; que, par suite, cette abrogation ne saurait faire obstacle à ce qu'elles soient contestées par la voie du recours pour excès de pouvoir".

http://www.dalloz.fr

(2)CE 24 oct. 2011, Shala, AJDA 2012, p. 43, concl. Thiellay J.P : "Considérant que pour que l'administration puisse se prévaloir des dispositions de cette circulaire à la date de la décision litigieuse, ces dispositions devaient avoir été à la fois publiées dans un bulletin officiel conformément aux prescriptions de l'article 29 du décret= 
من الأول من مايو 9 . . ب فإن مجرد النشر في النشرة الوزارية الرسمية لا يكفي وحده للاحتجاج بالمنشور في مواجهة المتعاملين مع جهة الإدارة حتى وإن كان ذات طبيعة

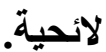

وتحقيقا للغرض المرجو من وراء النشر على الموقع الالكتروني فقد حرص المجلس على التاكيد على وجوب نثر نص المنشور كاملاً على الموقع الاكترونسي فلا يكفي مجرد نشر موجز أو جزء منه مع الإحالة إلى النشرة الرسمية الوزارية للإطلاع عليه، فمثل تلك الإحالة وذلك النشر الجزئي ليس من شـأنه إنقاذ المنشور من الإلغاء، أو إعطاء الحق في التمسك بأحكامه في مواجهة الأفراد'). غير أن مرسوم ^ . . ب و إن كان قد فرض ازدواجية النشر والتي تصب بكل

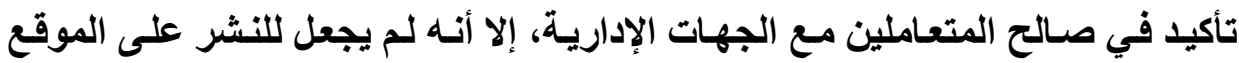
الاككتروني أية أثر بالنسبة لسريان مدة الطعن القضائي، فهذه الأخيرة ما زالت مرتبطة

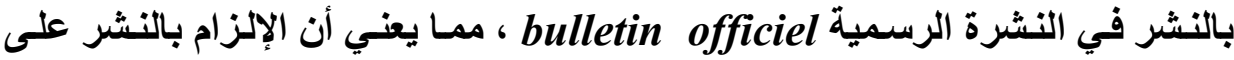
الموقع الاكترتوني والتقاضي أمران مختلفـان، بـليل أن مجلس الدولية كمـا رأينا قبل الطعن ضد المنشور إذا كان رغم عدم نشره على الموقع الاكتروني للمنشورات قد تم

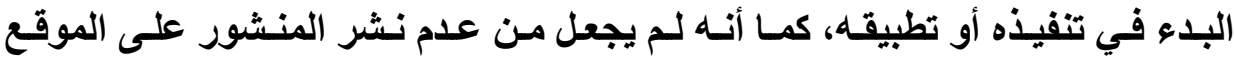
الاكتروني في حالة قبول الطعن ضده وجها من أوجه عدم المشروعية التي تسمح لـه

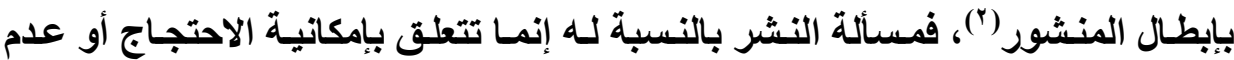

$=d u 30$ décembre 2005 et mises en ligne conformément à celles de l'article ler du décret du 8 décembre 2008".

(1)CE 24 oct. 2011, Shala, AJDA 2012, p. 43, op.cit.

(2) CE 9 nov. 2011, GISTI, AJDA 2011.p. 2205

lv o مجلة البحوث القانونيتوالإقتصاديت 
الاحتجاج بالمنشور في مواجهة المتعاملين مع الإدارة دون أن يكون لها أدنى تأثثير على مشروعية المنثور نفسه.

= و هو ما يتفق مع قضاء المجلس بالنسبة لمسألة النشر حيث أكد في أكثر من موضع على أن نشر العمل أو القر ار لا شأن له من حيث المبدأ بمشرو عيته:

CE 27 mars 1914, Laroche, S.1914.3.97, note Houriou; 9 mai 1962, Assoc. Le Cercle d'entraide sociale, Rec. p. 304; 24 février 1999, Meyet ,req. $n^{\circ} 188154$ : "les conditions de publication d'un acte sont en principe sans influence sur sa légalité".

و هو ما أكده أيضأ مجلس الدولة المصري في أكثر من موضع من ذلك على سبيل المثال:

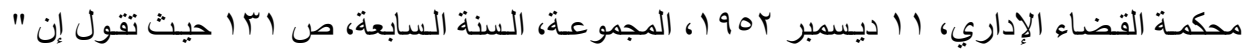

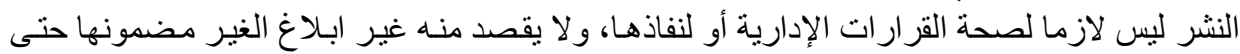

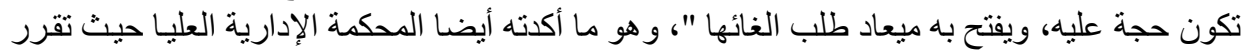

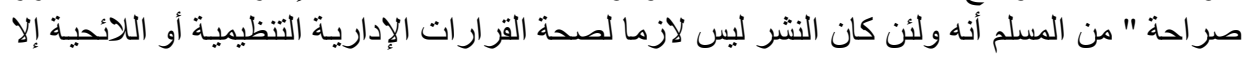

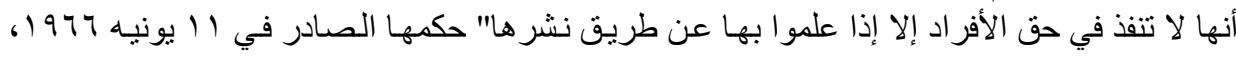

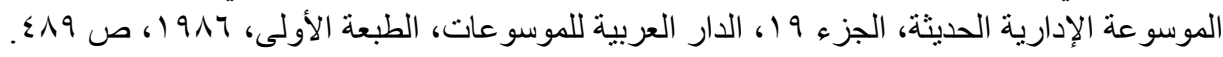

مجلت البحوث القانونيت والإقتصاديت V V 


\section{خاتمة}

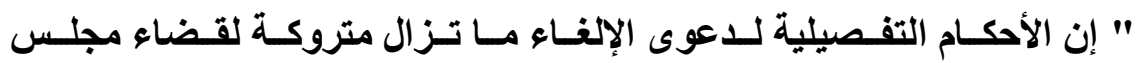
الدولـة..ولهذا امتـازت أحكام دعوى الإلغـاء في القضاء الإداري الفرنسي بمرونتها التامــة، وتطورهـــا المـستمر مسن وقـت لآخـر، لكـي تـستجيب لمقتــيات الإدارة

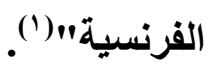

هذه العبـارة تجسد في الواقع التطور القضائي الذي شـهـته في فرنسا تلكـ

الطائفة من الأعمال الإدارية التي يطلق عليها المنشورات أو التعليمات الإدارية.

فبعد أن قام القاضي الإداري الفرنسي بالنظر إليها كما رأينا على أنها لا تعدو في مواجهة الأفراد مجرد تدبير أو إجراء داخلي بحت يخص الإدارة وحدها لا شأن لهم بـه، وبناء عليه رفض الاعتر اف لهم بالحق في الطعن عليها، قاصراً هذا الحق على طائفة الموظفين الموجه إليهم المنشور حـال مساسه بمر اكزهم وأوضـاعهم القانونية ، فبان قضائه تطور بعد ذلك مظهراً واقعيته واهتمامسه بحمايـة المتعـاملين مـع جهة الإدارة،

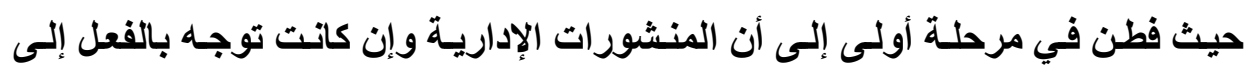
الموظفين فإن ذلك إنما يتم لتطبيق مـا تتضمنه من تفسيرات وتوجيهات وتعليقات في علاقاتهم مع المتعاملين معهم من الجمهور، مما يعني أنه يتعين عدم الوقوف عند صفة متلقي المنشور لتحديد من له حق الطعن، وإنما يجب فحص مضمونها ومحتواه لتحديد ما إذا كان قد وقف عند حد التفسير والتوضيح، أم أنـه قد أضـاف جديدا بمـا يؤثر في المراكز والأوضاع القانونية للأفراد، وترتيبا على ذلك ق قام بشأن قبول الطعن كمـا رأينـا بـالتمييز بين نـوعين من المنشورات: المنشورات التفسيرية والمنشورات اللائحيـة، 
مجرداً الأولى من أية قيمة قانونية معتبرا إياها مجرد عمل داخلي صرف لا شأن للأفراد به، أما الثانية فاعتبرها مصدراً من مصادر المشروعية مثلها في ذلك مثله أي قرار لانحي.

وقد رأينا أن معيار الإضافة أو الاستحداث وإن كان قد سـاهم في إخضاع جاتب من المنثورات الإدارية لرقابة القضاء، إلا أنه لم يكن سهل التطبيق وهو ما أضفى كما رأينا على قضائه في هذا الخصوص طابع التحكم وأدى إلى حدوث اضطراب في التحليل وفهم النظام القانوني لتلك الطائفة من الأعمال الإدارية. وقد ازداد الأمر تعقيداً واضطراباً كما رأينا عندما حاول مجلس الدولة الفرنسي

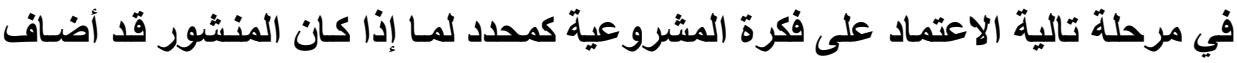

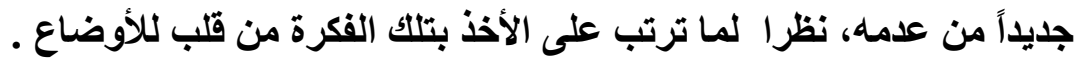
وقد انتهينا من تحلينا لمعيار الإضافة أو الاستحداث الذي اعتمد عليه القاضي الإداري في تقسيمه للمنشورات إلى لانحية وتفسيرية، إلى أنها ينطلق في تقدرينا من

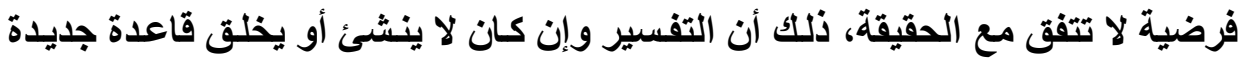

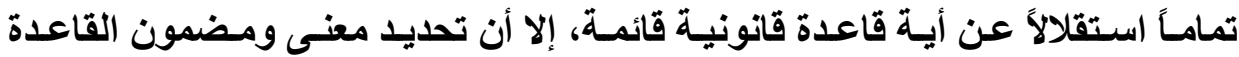

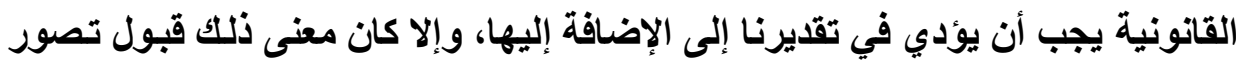

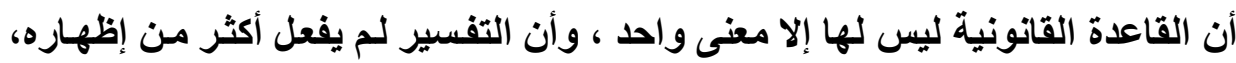
وهو ما يعد تصوراً نظرياً محضاً، ذلكت أن القاعدة القانونية تتضمن في الغالب الأعم التاني أكثر من معنى، ومن ثم فإن قيام الرئيس الإداري باختيار واحداً من بين كل التهل التفسيرات

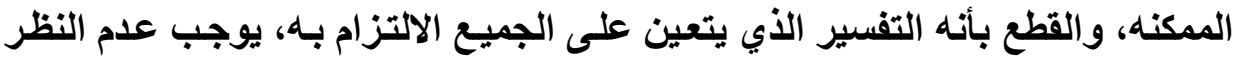

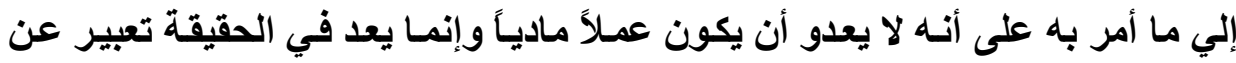
الإرادة مرتب لآثر قانوني، صحيح أن القراعة التي تم فرضها من خلال المنشور ترتكز

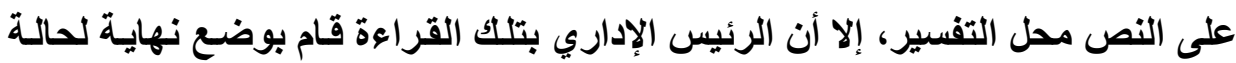


عدم اليقين الناجمة من تعدد التفسيرات الممكنة للنص، مما يعني أنسه يتعين النظر إلى في التفسير الذي يتم فرضه على المرؤوسين في هذه الحالـة على أنسه يعد منشئ لقاعدة

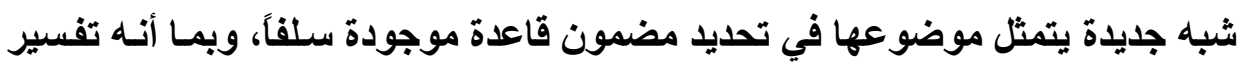

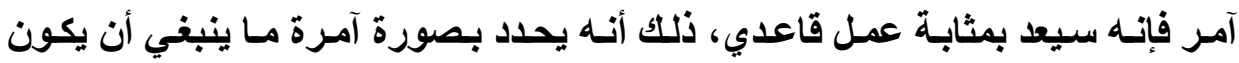
أو Devoir-être أو ويفرض بالتالي قبول الطعن ضده بالإلغاء، وهو ما حاولت

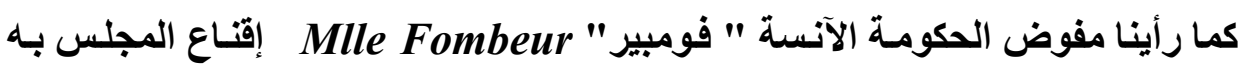
بصورة غير مباشرة في تقريرها المقدم في قضية "دوفينيير" Duvignières ، حيث

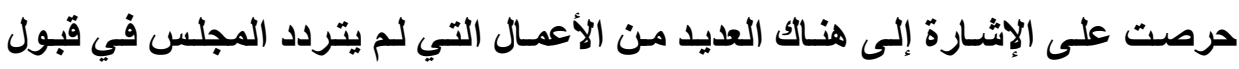
الطعن ضـدها بالإلغـاء رغم أن الفرض فيهـا أنها لا تضيف جديدا، وفي مقدمسة تلكـ الأعمال أشـارت إلى المراسيم التفسيرية أو التطبيقية أو التففيذيـة ، حيث قبل المجلس

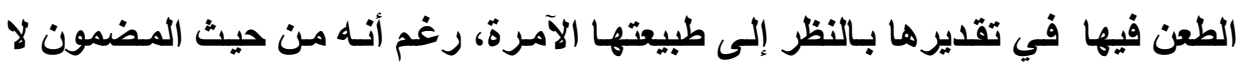
يوجد اختلاف حقيقي بين ما تتضمنه وبين المنشورات التي تفسر بطريقة آمرة القواعد التثريعية أو اللائحية الناقذة.

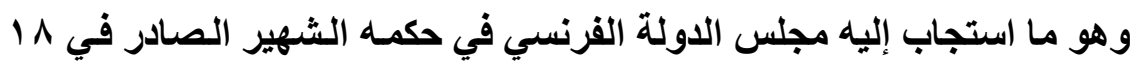
ديسمبر r . . ب في قضية "دوفينيير" Duvignières سـالف الذكر، مقررا التخلي بالنسبة لقبول الطعن بالإلغاء عن تقسيم المنشورات إلى لائحيـة وتفسيرية والاعتمـاد

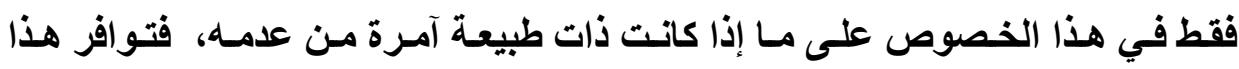
الوصف في المنشور أصبح منذ هذا التاريخ كافياً في نظر القاضسي الإداري الفرنسي لجعل دعوى الإلغاء مقبولة دون حاجة لبحث ما إذا كـان المنشور قد أضساف جديدا من عدمه، بل حتى وإن ثبت بأنه لم يفعل أكثر من ترديد الحكم المنصوص الإنه عليه في القانون الذي يتم التعليق عليه، فمجرد احتواء المنشور على أحكام آمره يعد كافياً بذاته في

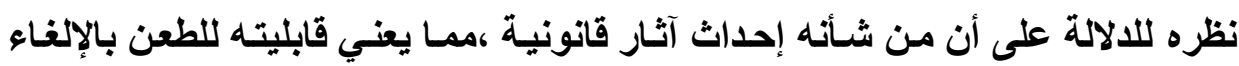
دون حاجـة للبحث عن العنصر الانشـائي الــي يــخل في التعريـف التقليـدي للقرار 
الإداري، مظهراً بذلك قدراً عالياً من المرونة والواقعية في نظرته لتلكت الطائفة من

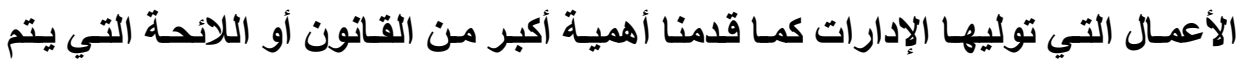

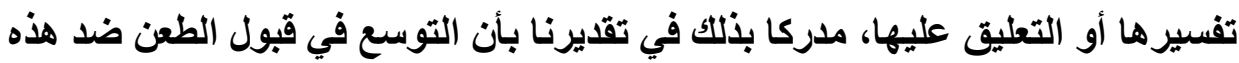

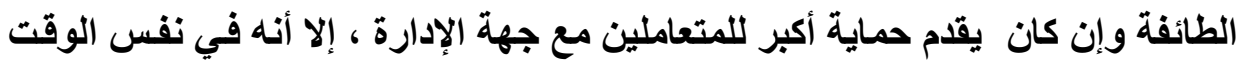
لن يتضمن أية إعاقة لنشاط الإدارة، ذلك أن قبول الطعن بالإلغاء كما نعرف ليس له له أثر الثر موقف، بمغنى أنه لا يترتب عليه وقف تنفيذ العمل المطعون فيه. غير أنه ليس معنى ما تقدم أن فكرة الإضافة أو الاستحداث قد اختفت تمامـاً من

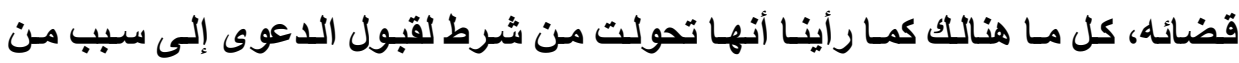
الأسباب التي يمكن أن تؤدي إلى الدكم بإبطال المنشور لعدم الاختصاص إذاذا ثبت عدام تمتع مصدره بالسلطة اللانحية.

ولا شكك أن ما انتهى إليه القاضي الإداري الفرنسي يمثل تقدما كبيرا بالمقارنـة بنظيره المصري، ذلك أنه من خلال الأحكام القليلة نسبيا الصادرة عن هذا الأخير، فإنها

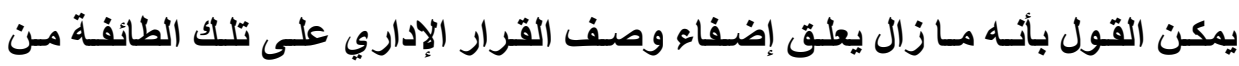

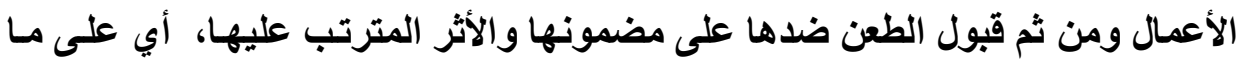

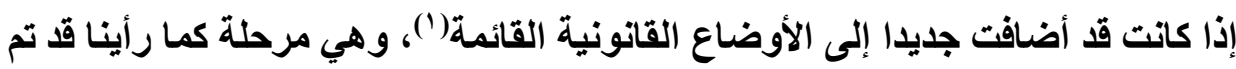

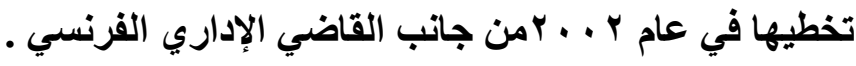

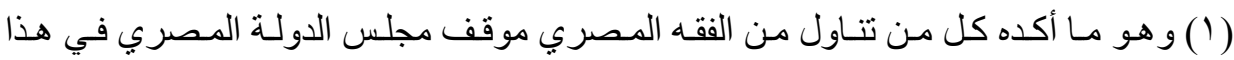

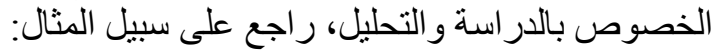

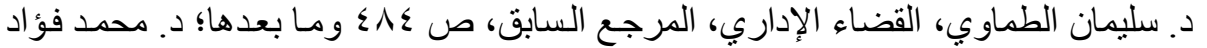

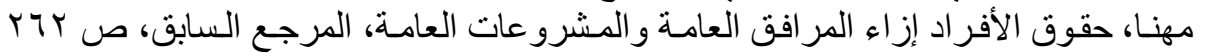

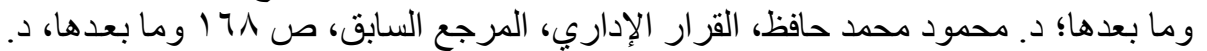

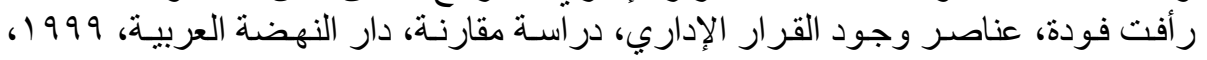

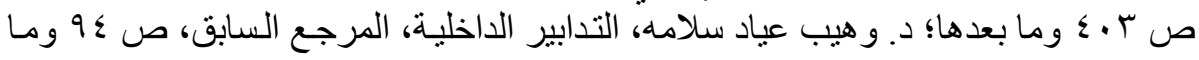


ولم يقف تطور النظام القانوني للمنشورات الإدارية في فرنسا عند حد القضاء،

ذلك أن الأهمية التي تحتلها تلكك الطائفة في الحياة الإدارية وحياة الأفراد جذبت أيضاً ـ

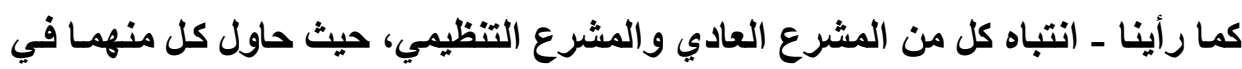
إطار تحسين العلاقة بين الإدارة والجمهور إضفاء قدر مـن القيمـة القانونيـة عليها بصرف النظر عن طبيعتها ، حيث فرض المشرع العادي بمقتضى قانون V اليوليو

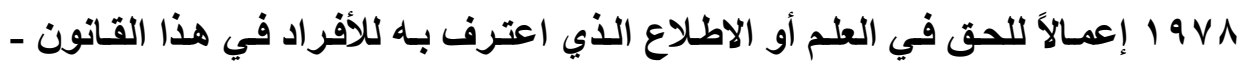

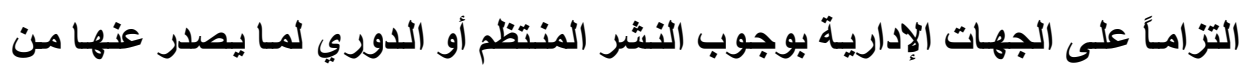

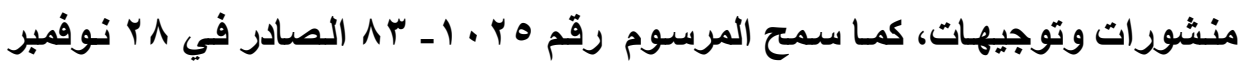

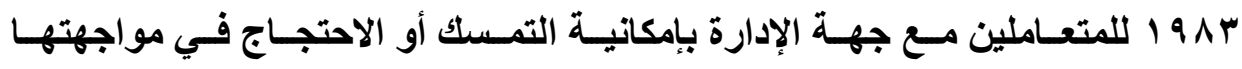

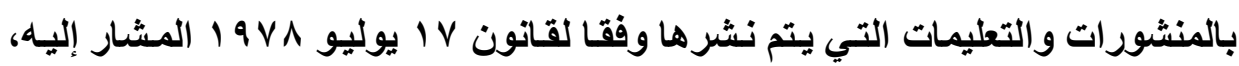

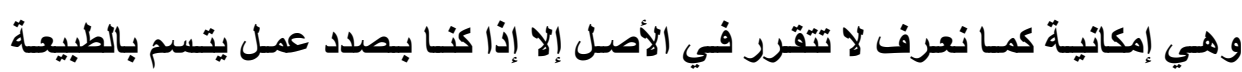
القاعدية، وقد رأينا ما أثثير بين الفقهاء من جلأل حول هذه المسألة. ورغم أن تلك المحاولات كما رأينا قد باءت بالفشل، نظرا لعدم التزام الجهات

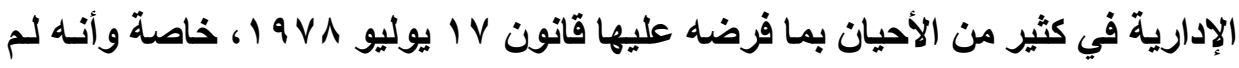

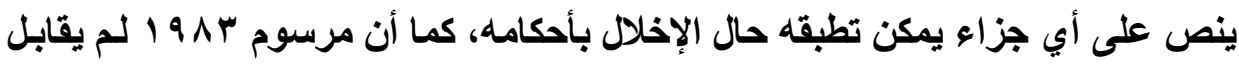

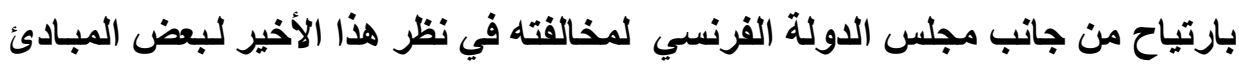

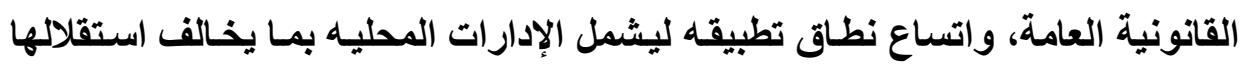

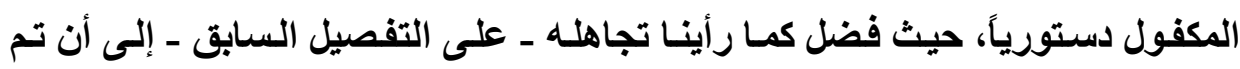

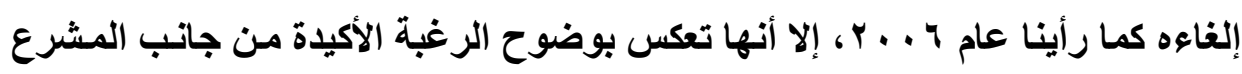

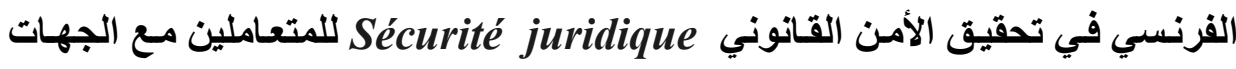

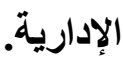

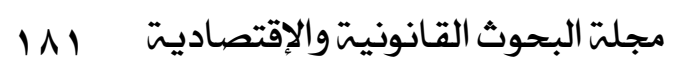


وقد كان للتقرير السنوي لمجلس الدولة الفرنسي لعام ؟ . . ب والذي أظهر فيه بوضوح مخاطر تلك الطائفة من الأعمال الإدارية، وبصفة خاصة المنثورات الوزاريـة

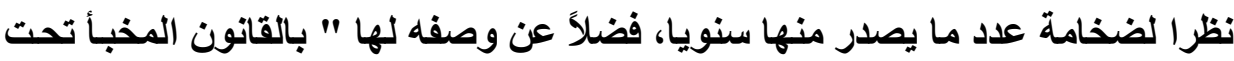
الأرض" droit souterrain. ، للالالة على صعوبة الوصول إليها ، أبلغ الأثر كما اليا رأينا في دفع الحكومـة المركزية نحو الاستمرار في العمل على إيجاد وسيلة أو آلية يمكن من خلالها إجبار الجهات الإداريـة على التصرف في وضـح النهار بجعل جميع منشوراتها بصرف النظر عن طبيعتها معلنة ومعلومة للجميع إعمالاً للحق في العلم أو اونا الاطلاع والذي يفرض الكشف عما تحت يدها من منشورات وتعليمات تتصرف في ضوئها دون أن تكون معلومة للجميع، حيث قام رئيس الوزراء بمقتضى المرسوم رقم

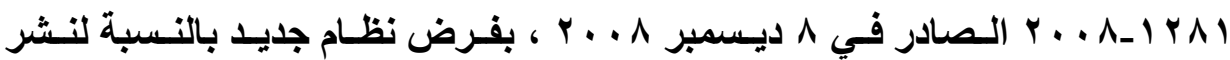
المنشورات الوزاريـة مقترن بجزاء فعال، ذلكك أنـه أوجب إلى جانب الالتزام بالنشر

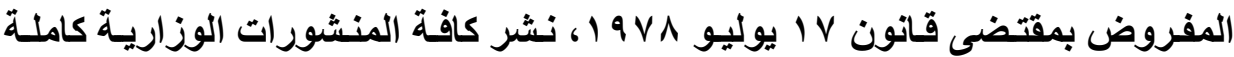
وبصورة يسهل معها للجمهور الرجوع إليها ، على موقع على شبكة الانترنت يتبع

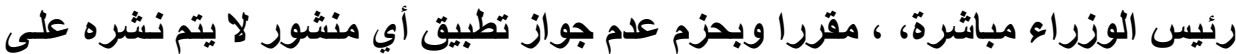

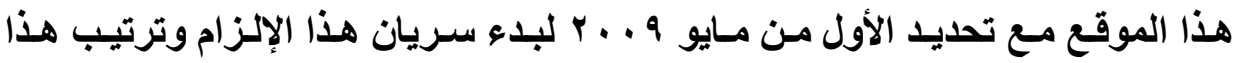
الجزاء ليس فقط بالنسبة لما سيصدر من منشورات بعد هذا التاريخ و إنما أيضا بالنسبة التابة

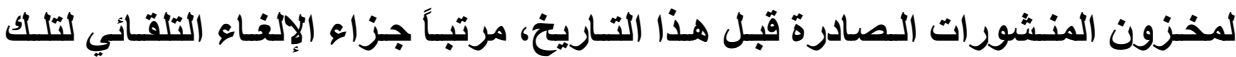
المنشورات إذا لم يتم نشرها على هذا الموقع حتى التاريخ المشار إليه، وقد رأينا مدى الدي الاعم الذي قدمه مجلس الدولة الفرنسي لهذا المرسوم حيث حرص على تطبيق أحكامه بكل دقة سواء فيما يتطلق بالإلغاء التلقائي للمنشورات السابقة على الأول من مـايو

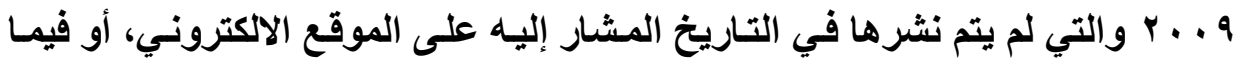
يتطلق بعدم إمكانية تطبيق أو الاحتجاج بالمنشورات الصادرة بعد هذا التاريخ ولا يتم 
نشر ها على هذا الموقع، وهو موقف كمـا هو واضـح مغـاير تمامـا لموقفه بالنسبة

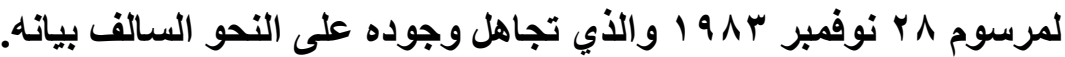

ولا شكك أن ما انتهى إليه هذا المرسوم يتسق في الواقع مع فكرة الصالح العام الذي تسعى الإدارة إلى تحقيقه، ذلك أن هذه الأخيرة إذا كاتت تعمل من أجل الصالح الصالح

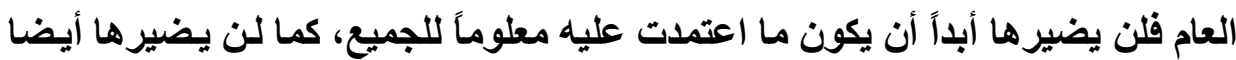
أن يحتج في مواجهتها بما انتهت إليه من تفسيرات وتعليقات في منشوراتها. لقد أثبت

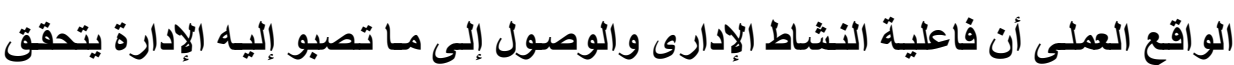
بصورة أفضل وأيسر فيما لو تم إثراك المواطنين فى هذا النشاطوذلكك بفتح الحوار معهم وتمكينهم من الإطلاع و الحصول على المعلومات و الوثثائق، الأمر الذَى لن يتأتى إلا بالتوقف عن النظر إليهم على أنهم مجرد مجموعة من المتطقلين. ولنا أن نتساعل في نهاية هذه الدراسة، ألا يدفعنا مـا انتهى إليه مجلس الدولية

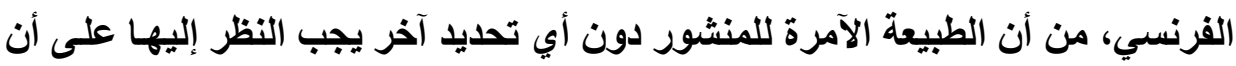
من شأنها إحاث آثار قانونية، إلى التفكير في وجوب إعادة النظر في التعريف التقليدي للقرار الإداري القابل للطعن فيه بالإلغاء. 


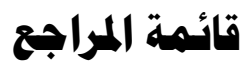

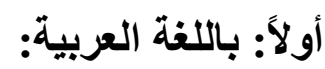

• د. أحمد أبو الوفا: المرافعات المدنيـة والتجارية، الطبعة الخامسة عشرة، منشأة

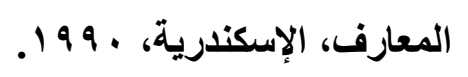

• د. أنس جعفر: القرارات الإدارية، الطبعة الثانية، دار النهضة العربية، ه . ب. • د. رأفت فودة: عناصر وجود القرار الإداري، دراسة مقارنة، دار النهضة العربية،

.1999

• د. رمضان محمد بطيخ: الوسيط فى القانون الإدارى، دار النهضة العربية، لو99 19. • حمدي ياسين عكاثـة: موسوعة القرار الإداري في قضاء مجلس الدولـة، الجزء

$$
\begin{aligned}
& \text { الأول، }
\end{aligned}
$$

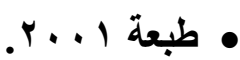

$$
\begin{aligned}
& \text { • د. سامي جمال الدين: }
\end{aligned}
$$

ـ دعاوى التسوية، منشأة المعارف، الإسكندرية، 1919 ا

ـ الدعاوى الادارية والإجراءات أمام القضاء الإداري، منشأة المعارف بالإسكندرية،

• د. سعاد الثرقاوي: القضاء الإداري، دار النهضة العربية، ـ191 ـ.

مجلت البحوث القانونيت والإقتصاديت ع 1 1 
ه. د. سعد أنور سعد قنديل: إجراعات التنظيم الداخلي للإدارة ورقابـة القضاء، دراسـة مقارنـة في النظـامين المـصري والفرنسي، رسـالة دكتـوراه، جامعـة المنـصورة،

د. د. سليمان محمد الطماوي:

ـ القضاء الإداري، الكتاب الأول قضاء الإلغاء، دار القكر العربي، 1919 ــ النظرية العامـة للقرارات الإداريـة، مطبعة جامعة عين شمس، الطبعة السادسة،

$$
\text { د. دلاح الاين فوزى محمد : }
$$

ـ المبادئ العامـة غير المكتوبـة في القـانون الإداري، دراسـة مقارنـة، دار النهضة

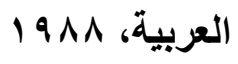

ـ المجلس الاستوري الفرنسي، الطبعة الثانية، دار النهضة العربية، با ب r. • د. طعيمة الجرف: رقابة القضاء لأعمال الإدارة، دار النهضة العربية، ب ج9 ا. • ـ.عبد الغنى بسيوني: ولايـة القضاء الإداري على أعمـال الإدارة، قضاء الإلغاء ،

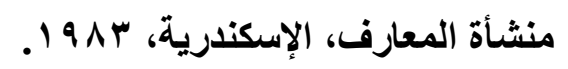

• د. عيد محمد القصاص: الوسيط في قانون المرافعـات المدنية والتجاريـة، الطبعة

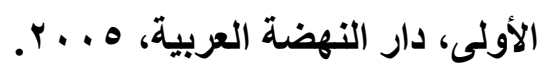
• د. ماجد راغب الحلو: القضاء الإداري، دار المطبوعات الجامعية، وVV • د. محمد ماهر أبو العنين: دعوى الإلغاء وفقا لأحكام وفتاوى مجلس الدولة، الطبعة

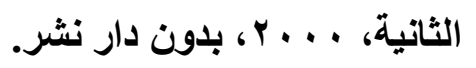


• د. محمد عبد الله نصسار: تدابير الإدارة الداخلية، دراسـة مقارنـة، رسـالة دكتوراه،

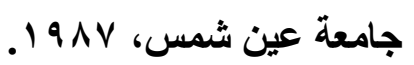

• د. محمد فؤاد عبد الباسط: أعمال السلطة الإدارية، الاسكندرية، 9199.

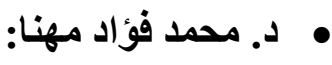

ــ القرار الإداري في القـانون الإداري المـصري والفرنسي، مجلـة لحقوق، جامعـة

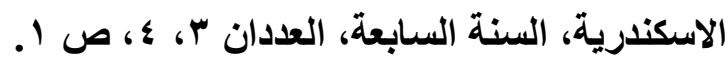
ـ حقوق الأفراد إزاء المرافق العامة والمشروعات العامة، معهد البحوث والدراسـات

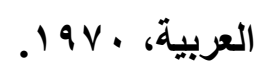
• د. محمد محمد عبد اللطيف: ـ القضاء الإداري، قضاء الإلغاء، دار النهضة العربية، ؟ . . ب. ـ المجلس الاستوري في فرنسا والتعديل الدستوري في بr يونيو ^ ـ . ب، مجلة

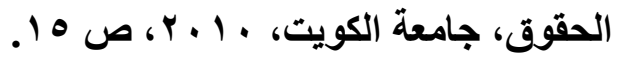
• د. محمود حلمي: القرار الإداري، القاهرة، الطبعة الثانية، ه191.

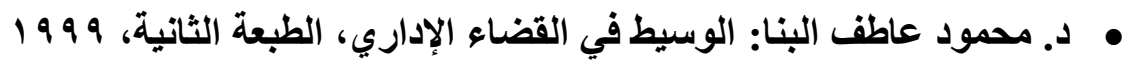
• د. محمـود محمــ حـافظ: القـرار الإداري، دراسـة مقارنـة، دار النهـة العربيـة، 1910. • د. مصطفى أبو زيد فهمي: القضاء الإداري ومجلس الدولة، الطبعة الرابعة، منشأة

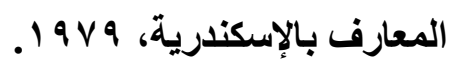


• د. وجدي راغب فهمي: مبادئ القضاء المدني " قانون المرافعات"، الطبعة الثالثة،

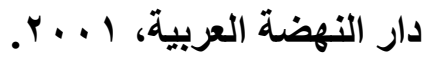

• د. وهيب عياد سلامة: التدابير الداخلية، منشأة المعارف، الإسكندرية، به19 ا.

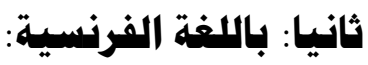

\section{$\underline{\text { I - Ouvrages generaux : }}$}

-Appleton J.: Traité élémentaire du contentieux administratif, Dalloz, 1927.

-Auby J-M et Drago R. :

- Traité de contentieux administratif. LGDJ 1984.

- Traité des recoures en matière administrative, Litec 1992.

- Benoit F.P. : Le droit administratif francais, Dalloz, 1968.

- Droit du contentieux administratif, Montchrestien, 13 ème éd., 2008

- Droit administratif général, Tome I, Montchrestien, 9 ème éd, 1995.

-Vedel G., Delvolvé P. : Droit administratif, Tome 1, PUF, 1990.

-Waline M. : Droit administratif, Sirey 9 ème éd. 1963. 


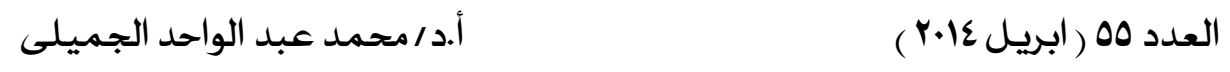

-De Laubadère A, Venezia J.C., Gaudemet Y.: Traité de droit administratif, Tome I, LGDJ. 11 ème éd 1990.

-Debbasch Ch.- Ricci J-C.: Contentieux administratif, 5 ème éd., Dalloz1990.

- Gonod P., Melleray F., Yolka P. : Traité de droit administratif, Dalloz, 2011.

-Dupuis G., Guédon M.-J.: Chrétien P. : Droit administratif, Colin, 5éd. 1996.

- Rivero J. waline J. : Droit administratif, Dalloz, 1994.

-Rolland L. : Précis de droit administratif, Dalloz, 10 ème éd, 1951.

-Moureau J.: Droit administratif, éd 1990, PUF.

-Hauriou M.: Précis de droit administratif et de droit public, éd. Sirey, 12ème 1933, rééd. Dalloz, 2002.

\section{II - Ouvrages speciaux - Thèses :}

-Alibert R.: Le contrôle juridictionnel de l'Administration au moyen du recours pour excès de pouvoir, Payot, 1926.

-Arroudj C. : De la fonction ministérielle, Thèse de l'Université de Lyon II, 2007. 


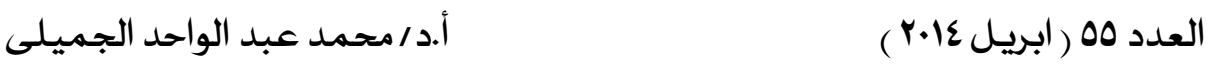

- Bemba J.: L'activité administrative non contrôlée par le juge, thèse, Rennes I, 1991.

-Bienvenu J-J.: L'interprétation juridictionnelle des actes administratifs et des lois : sa nature et sa fonction dans l'élaboration du droit administratif, Thèse, Paris II, 1979.

- Brando S.: L'autorité des circulaires administratives en droit pénal, Travaux et recherches de la Faculté de droit de Paris, PUF 1967.

-Célard A.: Le partage du pouvoir réglementaire de l'État (Contribution à l'étude du système normatif du droit public français), thèse, Lille II, 1995.

-Chevallier J.-J. : L'instruction de service et le recours pour excès de pouvoir, Thèse Nancy 1924.

-Ciaudo A.: L'irrecevabilité en contentieux administratif français, Thèse, L'Harmattan, coll. Logiques juridiques, 2009.

-Combeau P.: L'activité juridique interne de l'administration, Thèse Bordeaux IV, 2000, p. 526.

-Delaunay B.: L'amélioration du rapport entre l'administration et les administrés, LGDJ, 1993. 
-Delvolvé P.: L'acte administratif, Sirey, 1983.

-Douence J.C.: Recherches sur le pouvoir réglementaire de l'administration, LGDJ, 1968.

-Flauss J.-F.: Les questions préjudicielles et le principe de séparation des autorités aministrative et judiciaire, thèse. Strasbourg, 1976.

- Gabolde C.: Recours en appréciation de validité, Répertoire Dalloz de contentieux administratif " RDCA", tome 3, 1997.

- Gaudemet Y.: Les méthodes du juge administratif, LGDJ, , 1972.

-Gerry-Vernières S.: Les "Petites "Sources du Droit. A propos des Sources Etatiques non Contraignantes, thèse, Economica, 2012.

-Gohin O. : Exception d'illégalité, Répertoire Dalloz de contentieux administratif "RDCA", Tome 2, 2005.

- Grelat G.: Essai d'une théorie juridique de l'instruction de service, thèse ‘Nancy ,1908.

- Groulier C.: Norme permissive et droit public, thèse, Limoges, 2006. 
- Guettier C.: Recours en appréciation de validité ", jurisclasseur administratif, fasc.1166, 1993, p. 1.

- Jeanneau B.; Les PDG dans la jurisprudence administrative, Sirey 1954.

-Kelsen H. : Théorie pure du droit, Dalloz ,1962.

- Koubi G.: Les circulaires administratives, Economica, 2003.

-Lasserre B, le noir N., Stirn B. : La transparence administrative, PUF, 1987.

-Long M., Weil P., Braibant G., Delvolve P., Genevois B.: Les grands arrêts de la jurisprudence administrative, 10 ème éd., Sirey, 1993 et 17 ème éd, Sirey, 2009.

-Mandrette G.: Les Instructions des supérieurs hiérarchiques en droit administratif, thèse, Paris, 1908.

- Mockle D.: Recherches sur les pratiques administratives pararéglementaires, thèse, LGDJ, 1984.

-Moreau F.: Le règlement administratif, étude théorique et pratique de droit public français, Paris 1902.

- Pavlopoulos P..: La directive en droit administratif, LGDJ, 1978.

مجلت البحوث القانونيت والإقتصاديت 191 


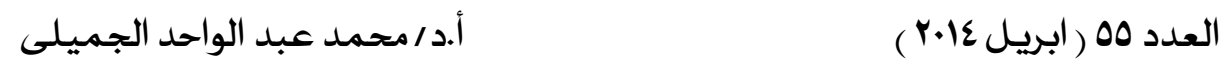

-Piazzon T. : La securite juridique, these Paris II, Defrénois, Paris, 2009.

- Ripert G.: Les forces créatrices du droit, LGDJ, 1955.

- Rivero J.: Les Mesures d'ordre Intérieur Administratives. Essai sur les caractères juridiques de la vie intérieure des services publics, thèse, Sirey, 1934.

-Seiller B.: Acte administratif, I - Identification, Répertoire Dalloz de contentieux administratif " RDCA", 2010.

-Seiller B.: L'exception d'illégalité des actes administratifs, Thèse Paris II, 1995.

-Seiller B. : Questions préjudicielles, Répertoire Dalloz de contentieux administratif " RDCA", Tome 3,.2000

-Stassinopoulos M.: Traité des actes administratifs, LGDJ, 1973.

-Van Lang A.: Juge judiciaire et droit administratif, LGDJ, 1996.

-Vedel G., Delvolvé P. : Le systéme français de protection des administrés contre l'administration, Sirey ,1991.

-Wiener C.: Recherches sur le pouvoir réglementaire des ministres, LGDJ, 1970. 


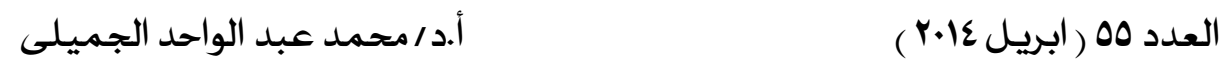

-Yelles-Chaouche B.: Recherches sur les mesures d'ordre intérieur, Thèse, Stasbourg 1981.

\section{III- Articles :}

-Abraham R: L'opposition à l'administration de sa propre doctrine, Droit fiscal. 1984, p. 149.

- Abraham R.: Le rôle de la pratique dans la formation du droit, RDP 1983, p. 1471.

-Amselek P.: L'opposition à l'administration de sa propre doctrine, les innovations apportées par le décret du 28 nov. 1983 Rev. Droit fisc. 1984, n $^{\circ}$ 4, p. 19.

-Auby J.-M : L’administration et ses usagers " le décret du 28 nov. 1983,. AJDA 1984, p. 124.

- Autin J.L.: Le conseil d'Etat et la constitutionnalité de la loi, Les petites affiches, $n^{0} 142$, p. 3 .

-Ayguebere J. : Valeur des circulaires et instructions ministérielles, Gaz. Pal., 1963, doctrine.

- Baraduc-Benabent E. et Pannentier L.: Sauf urgence ... sous réserve ... et exception faite ou le décret du 28 novembre 1983, D. 1984, p. 93. 


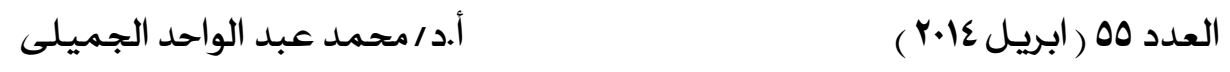

- Barrois de Sarigny C. : Les mesures d'ordre intérieur dans la fonction publique, Cah. Fonct. publ. $n^{\circ}$ 248, septembre 2005, p. 14

- Benetti J.: La genèse de la réforme, AJDA 2010 p. 74. .

- Bergeres M-C. : Les actes non réglementaires », AJDA, 1980, p,3.

- Blumann C. : L'application des circulaires administratives par le juge judiciaire, AJDA 1972, p263.

- Boiteau C. : Recours en appréciation de légalité et en interprétation, JCJA, T. 1, Fasc.37, éd.2002.

- Boulouis J. : Sur une catégorie nouvelle d'actes juridiques, les « directives », Mélanges Eisenmann, 1975, Cujas, p. 191.

- Braibant G. Stirn B. : Le droit administratif français, Dalloz, 6 ème éd., 2002.

- Braibant G. : Droit d'accès et droit à l'information, mélanges Charlier, 1981, P. 701.

- Chaltiel F. : Actualité des circulaires, AJDA, 2011, p. 1030.

-Chapus R. : De la valeur juridique des principes généraux du droit et des autres regies jurisprudentielles du droit adrmuistratif, D 1966, l, p.99. 
-Charlier P.-E. : Circulaires, instructions et autres prétendues mesures d'ordre intérieur administratives, ICP 1954, I, doctr. 1169.

-Cliquennois M : Que reste-t-il des directives "Crédit foncier de France", AJDA, 1992, doctrine, p.3.

- Cocatre-zilgien A.: La nature juridique des mesures d'ordre intérieur, RISA, 1958, p. 487.

- Collet M. : La recevabilité du recours en annulation contre les instructions fiscales, RD fisc. 23 juin $2005, n^{\circ} 25$, p. 1071.

-Combau P. : Un oubli dans la réforme : l'invocabilité des circulaires et instructions administratives ", AIDA, 2000, p. 495.

- Combau P. : Une avancée dans le contrôle juridictionnel des circulaires ?, Les PetitesAffiches, 23 juin 2003, $\mathbf{n}^{\circ}$ 124, p. 19.

- Combeau P. et Formery S. : Le décret du 8 décembre 2008 : un nouvel éclairage sur le « droit souterrain » ?, AJDA 2009, p. 809.

-Combeau P. : Du nouveau en matière d'invocabilité de l'interprétation administrative. Le cas de la doctrine sociale dans la loi de simplification du droit, JCP 2005, p. 1331 
-Combeau P. : Le décret du 28 novembre 1983 est mort, vive la loi ?, AJDA 2006, p. 1745.

-Combeau P. : Réflexion sur les fonctions juridiques de l'interprétation administrative, RFDA 2004. 1069.

-Coudray Y. : Les conditions de recevabilité du recours direct en interprétation, $R D P, 1981$. p.331.

-Darrieutort J-P. : L'article 1" du décret du 28 novembre 1983 est-il utile au contribuable?, Dr. fisc. 1994, $n^{0}$ 49, p.1744.

-Darville- Finet C.: La circulaire administrative. Nouvelle source formelle du droit ?, Annales de la Faculté de droit, d'économie et de sciences sociales de Liège ‘1982 $\mathbf{n}^{\circ} 2$.

-David C. : Le pouvoir d'organisation du service : une jurisprudence toujours en mouvement ", Dr. $\operatorname{adm} . \mathbf{n}^{\mathbf{2}} \mathbf{2}$, février 2006, p11.

-Deguergue M. : Nature et régime juridiques des circulaires ministérielles, AJDA, 1991, 802.

-Delamarre M. : La sécurité juridique et le juge administratif français, AJDA 2004, p. 186. 
-Delvolvé P. :

- De nouvelle Modalités pour les actes Administratifs unilatéraux "Le décret $n^{\circ}$ 83-1025 du 28 novembre 1983 concernant les relations entre l'administration et les usagers", D. 1984, chron. P. 137.

- La notion de Directive, AJDA 1974 p. 459.

-Dero-Bugny D. : La compétence du juge administratif saisi d'un recours en appréciation de validité d'un acte administratif encadrée par le renvoi préjudiciel du juge judiciaire, RFDA 2006, p. 73.

-Dibout P. : La liberté d'accès aux documents administratifs, Rev. adm. 1979, p. 23.

-Divier P. F. : L'administration transparente, RDP 1975, P. 59.

-Domino X.: Les joies de la modernité : une décennie de contentieux des circulaires, AJDA, 2012, p. 691.

-Donnat F. et Casas D.: L'office du juge administratif dans la jurisprudence récente du Conseil d'Etat, Dr. adm. 2004. p. 9 
- Donnat $\mathrm{F}$. : Les dispositions impératives à caractère général d'une circulaire ou d'une instruction font grief, AJDA 2003 p. 487.

-Douat E. : Les mérites comparés de l'article L. 80-A du L.P.F et de l'article 1er du décret du 28 novembre 1983, Les Petites Affiches, 14 oct. 1991, n 123, p. 7.

-Drouot G. : Le décret du 28 nov. 1983, AEAP 1984, p. 461.

-Duguit L. : Traité de droit constitutionnel, tome II, Albert Fontemoing, 1928.

-Even B. : La notion de document administratif, AJDA 1985, p. 528.

- Février J-M. : Remarques sur la notion de norme permissive, D 1998. Chron. 271.

- Fliniaux A. : Le recours en appréciation de validité, Mélanges Hauriou, Sirey, 1929, p. 297.

-Fourgoux J-C. : Répression des fraudes, la réglementation par voie de circulaires, Gaz. Pal. 1963, 2, doctr. p. 43.

- Fromont M. : Le principe de sécurité juridique, AJDA 1996, $\mathrm{n}^{0}$ spécial Droit administratif et droit communautaire, $\mathbf{p} 178$. 
- Gaudemet Y. :

- Remarques à propos des circulaires administratives, Mélanges Stassinopoulos, LGDJ, 1974, p. 559.

- Les Actions administratives informelles, Revue internationale de droit comparé " RIDC", 1994 Volume 46 n' 2 p. 645.

-Gazier F., Long M. : Observations sous CE Ass., 29 janvier 1954 Institution Notre-Dame du Kreisker, AJDA, 1954, II, chronique, p. 5.

- Genevois B.: Le conseil d'Etat n'est pas le censeur de loi au regard de la constitution, RFDA 2000, P. 715.

- Girardot T-X. : Le retour de la loi écran devant le juge des référés. La jurisprudence Carminati confirmée par le juge des référés du Conseil d'Etat, AJDA 2006. p.1875.

-Pontier J-M. : Qu'est-ce que le droit administratif ?, AJDA 2006, p.1937.

-Boulois J. : Sur une catégorie nouvelle d'actes juridiques : les " directives", Mél. Eisenmann, Cujas, 1975, p. 191.

-Granjon D. : Les questions préjudicielles, AJDA 1968, p.75. 
-Groulier G. : L'impératif dans la jurisprudence Duvignères, réflexion sur un « sésame contentieux », RFDA, 2008, p.941.

- Guez J. : La normalisation du recours pour excès de pouvoir contre les circulaires administratives, AJDA, 2005, p. 2445.

-Haïm V. : L'article L. 80 A du Livre des procédures fiscales est-il inconstitutionnel ? Droit fiscal. 1995, $n^{\circ} 12$, p. 549.

- Hecquard-Theron M. : De la mesure d'ordre intérieur, AIDA 1981, p.235.

- Heinis M. : L'art. 1er du décret du 28 novembre 1983 devant le juge de l'impôt, Les Petites Affiches 1er juill. 1994, no 78, p. 7.

- Helin J.C. : la protection du citoyen contre l'administration, réflexion sur l'evolution contemporaine des voies de la protection, Les Petites Affiches, 23 nov 1990, P. 9.

-Heurté A. : Le recours sur renvoi des tribunaux judiciaires, AJDA 1958, 1, p. 111.

- Hoekema A. : La production des normes juridiques par les administrations, Droit et Société, n ${ }^{\circ 2}, 1994$, p. 303.

-Iliopoulou A.: Quatre ans d'application de la jurisprudence Duvignères, RFDA 2007 p. 477.

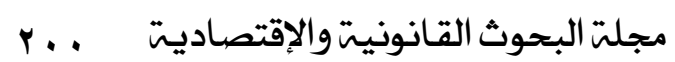


-Jackson B. : La notion de décisions faisant grief dans le cadre du recours pour excès de pouvoir, Les Petites Affiches, $\mathrm{n}^{\circ} 12,18$ janvier 2000, p.14.

- Jeammaud A. : Les contrôles de la légalité du règlement intérieur, Dr. soc. 1983, p. 520.

- Jeanneau B. : La théorie des principes généraux du droit à l'épreuve du temps, EDCE 1981.1982, nº 33.

- Jegouzo Y. : Le droit à la transparence administrative, EDCE 1991, N 43, P. 199.

- Kelsen H. : Théorie pure du droit, Dalloz 1962.

- Koubi G. :

- Administration électronique et circulaires administratives, AJDA, , p. 953.

- Distinguer « l'impératif» du « réglementaire» au sein des circulaires interprétatives, RDP. 2004. 499.

- Vers une définition jurisprudentielle de la circulaire administrative interprétative, Les Petites Affiches, 4 mars 2003, p. 19.

- Administration électronique et circulaires administratives, JDA, 2006, p. 953. 
-Circulaires interprétatives et jurisprudence administrative, Les Petites Affiches, 24 janvier 1996, p. 17.

- De la validité des circulaires administratives antérieures au 1er mai 2009, Revue de droit sanitaire et social 2011, p. 514.

- L'irrecevabilité des requêtes des agents publics contre les instructions de service interprétatives, JCP Adm., $n^{\circ}$ 6, 2 février 2004, Jur. 1065, p. 146.

- La date de la mise en ligne d'une circulaire, AJDA 2011, p. 529.

- Vers une définition jurisprudentielle de la circulaire administrative interprétative, Les Petites Affiches, 4 mars 2003, p. 19.

- Laferrière E. : Traité de la juridiction administrative et des recours contentieux Berger- Lenault, tome $I, 1^{\text {re }}$ éd., 1887.

- Lamarque J., Négrin O. Ayrault L. : Droit fiscal général, LexisNexis, 2 ème éd., 2011.

- Lasserre B. : Six ans après le vote de la loi du 17 juillet 1978, une administration plus transparente ? EDCE 1983 - 1984, P. 99. 
- Laveissiere J. :

- L'accès aux documents adrninistratifs ", dans Information et Transparence administratives, C.U.R.A.P.P., PUF 1988, p. 11.

- Le droit à l'information à l'épreuve du contentieux, A propos de 'accès aux documents administratifs, D, 1987, P. 275.

- Le Pors A. :

- Chronique d'une mort annoncée : le décret du 28 novembre 1983, JCP Adm., $n^{\circ}$ 6, 2007. 2021

- Du nouveau dans les relations administration-citoyens ?, AJDA 2007. 626.

- Lemasurier J. : vers une démocratie administrative : du refus d'informer au droit d'être informé, RDP 1980, $P$. 1239.

- Lepage-Jesscua C. : Le décret dn28 nov. 1983 concernant les relations entre l'administration et les usagers : une minirévolution?, Gaz. Pal. 1984, doctr. p. 145.

- Le Prado D.: La question prioritaire de constitutionnalité vue par un avocat, AJDA, p. 94. 


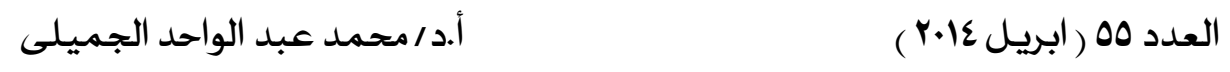

- Letteron R. : L'administré et le droit à l'information, Thèse, paris $X, 1987$.

- Levantal L. : L'annulation pour excès de pouvoir des circulaires administratives, S., 1954, chron. p.99.

- Liet-Veaux G. : Les actes administratifs qui "ne font pas grief', Rev. adm. 1952, p. 384.

- Linotte D. : Commentaire de la loi $n^{0}$ 78-753 du 17 juillet $1978 »$, RDP 1978, p. 1417.

- Maisl H., Wiener C., Woehrling J-M. : Un décret ne fait pas le printemps, AJDA 1984, p. 137.

- Massot J.: Décisions non formalisées et contrôle du juge de l'excès de pouvoir, dans L'Etat de droit, Mélanges Guy Braibant, Dalloz, 1996, p. 521.

- Mathiot A. : Bureaucratie et démocratie, EDCE, 1961, P. 11.

- Moreau J. : Sur l'interprétation du mot "interprétation" à propos des circulaires réglementaires et des circulaires interprétatives, JCP adm, 2003, 1064.

- Noël G. : Les vicissitudes des circulaires opposables, RJCO 1989, no 4, p. 17.

- Nsimba J. : La notion d'acte faisant grief dans le droit administratif français, Thèse Rennes l, 1987. 
- Odent R. : Contentieux administratif, Université de Paris, Institut d'études politiques, Les cours de droit, Fascicules I et II, 1949-1950.

- Olléon L. : Recours pour excès de pouvoir contre les instructions fiscales : la photographie du droit existant n'est pas contestable, Revue de jurisprudence fiscale 2004, p. 271.

- Pacteau B. :La sécurité juridique, un principe qui nous manque?, AJDA 1995, $\mathbf{n}^{0}$ spécial Le droit administratif, p. 151.

- PELISSIER G. : Développements récents de l'impératif de sécurité juridique, Les Petites Affiches, 20 février 1998, no 22, p.6.

- Pelissier J. : Le règlement intérieur et les notes de service, Dr. soc. 1982, p. 75.

- Prétot X. :

- Le régime des circulaires et instructions est-il réductible à la recevabilité du recours pour excès de pouvoir?

Quelques réflexions à la lumière de la décision Mme Duvignères,Mélanges. Franck Moderne, Dalloz, 2004, p. 357. 
- De l'esprit des circulaires et instructions ... et des rapports qu'elles entretiennent avec le droit social, RJS, 1997, p. 415.

- Rabault H. : L'opposabilité de la doctrine administrative en droit fiscal : la constitutionnalité de l'article L 80 A du Livre des Procédures Fiscales, Les Petites Affiches, 15 juin 2012, n'120, p. 20.

- Roblot-Troizier A.: La question prioritaire de constitutionnalité devant les juridictions ordinaires : entre méfiance et prudence, AJDA 2010, p. 80.

- Saussay C. : Le pouvoir réglementaire du chef de service, dans La continuité des services publics, PUF, 1973, p.41.

- Sauve J.M.: Vingt ans après ...l'arrêt Nicolo, Gaz. Pal. 12 fév. 2009 , p. 5.

- Schwartz R. : Le pouvoir d'organisation du service, AJDA 1997, n" spécial Le service public, unité et diversité ; p. 47.

- Stéphane G-V. : Les « Petites »Sources du Droit. A propos des Sources Etatiques non Contraignantes, thèse, Economica, 2012.

- Turot J. : Les recours en annulation contre la doctrine administrative, Revue de jurisprudence fiscale, $n^{\circ} 8-9$, aoûtseptembre 1990, chrono p. 535. 
Notes, Conclusions et Observations :

- Braibant G. :

- Concl. Sur CE, Sect., 12 mars 1965, Fédération des chambres syndicales des négociants importateurs de la métallurgie et de la mécanique, JCP 1966, II, n 14771.

- Concl. Sur CE, 13 juill. 1962, Conseil national de l'Ordre des médecins, RDP 1962, p. 739.

- Delvolvé P. : Obs.sur CE 19 juin 1981, Union gén. des fédérat. de fonctionnaires, D 1981, IR, p. 519.

- Fombeur P. : Concl. Sur CE, Sect., 18 déc. 2002, Duvignères, RFDA 2003, p. 280

- Fombeur P. : Concl. Sur CE, Sect., Duvignères, 18 déc. 2002. RFDA 2003, p. 274.

- Fournier J. : Concl. Sur CE. Sect. 2 décembre 1966, Sieur Marchand et autres, Rec. p. 632, RDP 1967, P. 562.

- Hauriou M. : Note sous CE, 22 février 1918, Cochet d'Hattecourt, S. 1921, 2ème cahier, IIIème partie, p. 9. 
- Petit J. : Les circulaires impératives sont des actes faisant grief, Note sous Conseil d'Etat, Section, 18 décembre 2002, Mme Duvignères, RFDA 2003 p. 510.

- Questiaux N. : Concl. Sur CE. 23 mai 1969, Société Distillerie Brabant, AJDA 1969, p. 643.

- Scanvic F. : Concl. Sur CE. 29 dèc. 1993, Krafft, JCP 1994, no 22301.

- Seiller B. : Circulaires et légalité, Note sous Conseil d'Etat, 27 mars 1996, M. Lome, RFDA 1997 p. 1218.

- Tricot B. : Concl.sur CE, Ass., 29 janv. 1954, Institution Notre-Dame du kreiskaer, R PDA 1954, p. 50.

- Thiellay J.P. : Concl.sur CE 24 oct. 2011, Shala, AJDA 2012, p. 43.

- Bertrand P. : Concl.sur CE, 11 déc.1970, Crédit foncier de France, Rec.p.750.

V - Rapport public du Conseil d'Etat :

- La sécurité juridique. Rapport public 1991, La documentation française 1992. 


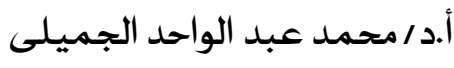

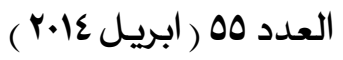

- La transparence de la vie juridique et administrative : progrès et limites, La documentation française 1996.

- Pour une meilleure transparence de l'administration, La documentation française 1998.

- Publication et entrée en vigueur des lois et de certains actes administratifs, La Documentation française, 2001.

- Sécurité juridique et complexité du droit - La Documentation française, 2006. 